\title{
Modernising the Common Law Offences of Assault and Battery
}

\author{
Graham McBain ${ }^{1,2}$ \\ ${ }^{1}$ Peterhouse, Cambridge, UK \\ ${ }^{2}$ Harvard Law School, USA \\ Correspondence: Graham McBain, 21 Millmead Terrace, Guildford, Surrey GU2 4AT, UK. E-mail: \\ gsmcbain@aol.com
}

Received: June 29, 2015 Accepted: July 24, 2015 Online Published: August 3, 2015

doi:10.5539/ilr.v4n1p39 URL: http://dx.doi.org/10.5539/ilr.v4n1p39

\section{Introduction}

The common law offences of assault and battery are one of the basic building blocks of the English criminal law. They are (like many common law offences) also very old. Indeed, battery is probably one of the oldest extant offences given that Anglo-Saxon law recognised 'wounding'- with an elaborate tariff of fines imposed depending on the nature of the injury inflicted. ${ }^{1}$ As for assault, this belongs to a politer age and it does not seem to have become a criminal offence until (probably) the $14^{\text {th }}$ century. ${ }^{2}$ In respect of assault and battery:

- Nature of Battery. Battery comprised - and still does - the infliction of unlawful physical injury on another. Thus, it includes offences such as homicide and rape as well as wounding. However, since Anglo-Saxon times, homicide and rape - as well as many other offences such as murder, manslaughter, mayhem ${ }^{3}$ and affray - have become independent offences. So too, the offence of false imprisonment ${ }^{4}$ as well as those of escape, prison breach and rescue ${ }^{5}$ - offences which also (often) involve assault or battery;

- Civil Remedy. Today, with the emergence of these independent offences, the ambits of assault and battery are more restricted in scope. Further, since early times, a civil remedy has been available;

- Defences. There have also been longstanding defences to assault and battery viz. where a person, acting reasonably: (a) acts in self-defence; or (b) acts to protect others; or (c) acts to protect his property or goods; or (d) where the assault or battery is lawfully administered by the requisite legal authorities; or (e) where (in the past) a man reasonably chastised his wife, child, servant, villain or apprentice for bad behaviour (or a teacher a child for the same, when acting in loco parentis). The rationale for these not being criminal was that they were to prevent a 'breach of the peace' (i.e. a crime) or to punish the commission of the same (eg. the lawful execution of a person for a crime) or to inculcate lawful obedience. There have also been cases where an assault or battery was held not to have occurred - such as in the case of surgery since it was therapeutic (that is, designed not to cause an injury, but to heal one). Further, in practice, minor (de minimis) assaults and batteries have not been subject to criminal punishment (and where they have been, the courts have usually only awarded a nominal sum);

- Consent. In modern times, it has been asserted that persons can consent to other than minor batteries being intentionally or recklessly committed against them (eg. when playing 'games' whether organised

\footnotetext{
${ }^{1}$ This tariff system continued from the $6^{\text {th }}$ century AD until (at least) c. 1113 (see 5). Anglo-Saxon law derived from Germanic law, since, by $\mathrm{AD} 500$, the Western Roman Empire gave way to a number of Germanic kingdoms and 'various Germanic peoples known as the Anglo-Saxons settled in Britain between the middle of the fifth and the middle of the sixth centuries.' See KF Drew, The Laws of the Salian Franks (University of Pennsylvania Press, 1991), p 25. This text contains a useful discussion on the supplanting of Roman law by Germanic law from the decline of the Roman Empire.

${ }^{2}$ The Laws of Henry I (c. 1113) (see n 8 and 5) suggest that the criminal law covered only actual (and not threatened) acts of violence. Further, that it covered intentional acts but not negligent or accidental ones, see ns $103 \& 104$.

${ }^{3}$ DM Walker, The Oxford Companion to Law (Oxford, 1980), (definition of mayhem) 'In medieval English law, an injury to the person which amounted to the deprivation of a member used for fighting. It could originally be prosecuted by an appeal of felony, but usually by proceedings for trespass. It is now treated as a malicious injury to the person.'

${ }^{4}$ See GS McBain, False Imprisonment and Refusing to Assist a Police Officer - The Need for Statutory Offences. Journal of Politics and Law (2015), vol 8, no 3, pp 51-99.

${ }^{5}$ See GS McBain, Modernising the Law of Escape, Prison Breach and Rescue. Review of European Studies (2014), vol 6, no 4, pp 147-73.
} 
sports, horseplay or sexual games, including sado-masochism). However, it is asserted that this is inaccurate since the criminal law - from early times - has never recognised that a person can consent to a 'breach of the peace'. Thus, if intentional or reckless, injury results, it is a crime, even if consensual (so too any non-therapeutic mutilation) unless the same is treated as minor or legislation expressly permits it (tattooing etc.). Thus, modern caselaw is in danger of creating a new 'defence' at common law, when there was none;

- $\quad$ Aggravated Batteries. Besides assault and battery at common law there are various aggravated assaults and batteries pursuant to legislation.

However, there are also many legal problems with the current law on assault and battery - such that it would be useful to put these offences into modern legislation. For example, 'assault' is often (incorrectly) used as a generic expression to cover battery as well as assault. This causes much confusion. Further, the definitions of 'assault' and 'battery' are old. They should be cast in a more modern, and intelligible, form. Finally, the actus reus and mens rea for these offences should be clarified - as well as the precise nature of the defences available.

In order to highlight these problems - as well as the means of their resolution - this article considers the history of these offences. Also, it analyses the references to assault and battery in the principal texts on criminal law from early, up to modern, times.

In conclusion, this article asserts that there should be new statutory offences of 'Violent Assault'(formerly, battery) and 'Threatened Violent Assault' (formerly, assault). And, that the criminal and civil forms should be (almost) the same. Also, that the aggravated forms of these offences should be reflected in the punishment - rather than in any change to the definitions of assault and battery. Finally, any aggravated offences should be few in number.

\section{Source Material}

With regard to this article, the following primary texts are considered:

- Anglo-Saxon Law. Reference is made to texts by Attenborough, Robertson and Thorpe, ${ }^{6}$ which contain translations of laws (dooms) from king Aethelbert (c. 518-616) until the Norman Conquest of 1066. Reference is also made to O'Brien, which contains an alleged version of the laws of Edward the Confessor (1042-66); ${ }^{7}$

- Medieval Texts. Reference is made to the Laws of Henry I (c. 1113) ${ }^{8}$ as well as to the first text on English law, by Glanvill (c. 1189). ${ }^{9}$ Also, to Bracton (c. 1240), ${ }^{10}$ Britton, (c. 1290), ${ }^{11}$ Fleta (c. 1290) ${ }^{12}$ and the Mirror of Justices (c. 1290); ${ }^{13}$

- Yearbooks, Selden Society Reports \& Book of Assizes. Reference is made to the Yearbooks $(1268-1535),{ }^{14}$ the Selden Society reports ${ }^{15}$ and the Book of Assizes (Liber Assisarum)(being criminal cases in the time of Edward III, 1327-77); ${ }^{16}$

- $\quad$ Abridgments. Reference is made to the abridgments of Statham (c.1490), ${ }^{17}$ Fitzherbert (c.1516) ${ }^{18}$ and Brooke (1586) ${ }^{19}$ as well as to the later abridgments of Hughes $(1660-3),{ }^{20}$ Rolle (1668), ${ }^{21}$

\footnotetext{
${ }^{6}$ FL Attenborough, The Laws of the Earliest English Kings (NY, 1963); AJ Robertson, The Laws of the Kings of England from Edmund to Henry I (Cambridge UP, 1925)(the latter covers legislation from AD 942 up to the reign of Henry I (1100-35)) and B Thorpe (ed), Ancient Laws and Institutes of England (1840).

${ }^{7}$ BR O'Brien, God's Peace and King's Peace. The Laws of Edward the Confessor (Univ. of Pennsylvania Press, 1999).

${ }^{8}$ LJ Downer, Leges Henrici Primi (Oxford, 1972).

${ }^{9}$ Glanvill, The Treatise on the Laws and Customs of the Realm of England (c. 1189)(Nelson, 1965).

${ }^{10} \mathrm{H}$ Bracton (trans Thorne), On the Law and Customs of England c.1240 (Cambridge UP, 1968-76). Bracton is now online, see bracton.law.harvard.edu

${ }^{11}$ FM Nichols (ed), Britton (John Byrne \& Co, 1901).

${ }^{12}$ Fleta, see Selden Society ('SS'), vols 72, 89 and 99.

${ }^{13}$ Mirror of Justices, SS, vol 7.

${ }^{14}$ The best edition is that of Maynard (Vulgate, 1678), reprinted by LBE. David Seipp (a professor at Boston university) has put translations of most of the 22,000 Yearbook cases online in the form of an Index. See www.bu.edu/law/faculty/scholarship/yearbooks).

${ }^{15}$ See selden.society.com. Also www.wshein.com/ which has put SS vols 1-99 online.

${ }^{16}$ See www.lawbookexchange.com/. The Liber was first published in 1516 (J Rastell).

${ }^{17}$ N Statham, Abridgment of the Law (Pynson, c. 1490). See translation of MC Klingelsmith (Boston Book Co., 1915).

${ }^{18}$ A Fitzherbert, La Graunde Abridgment. The $3^{\text {rd }}$ ed (1577) is generally preferred and it is cited in this article. The $3^{\text {rd }}$ edition has been reprinted by the Law Book Exchange.

${ }^{19}$ R Brooke, La Graunde Abridgment (Tottell, 1586).
} 
Sheppard (1675), ${ }^{22}$ Nelson (1725-6), ${ }^{23}$ Viner $\left(1^{\text {st }}\right.$ ed, 1741-57), ${ }^{24}$ Bacon $\left(5^{\text {th }}\right.$ ed, 1798) ${ }^{25}$ and Comyns (last ed, 1822); ${ }^{26}$

- $\quad \mathbf{1 6}^{\text {th }} \& 17^{\text {th }}$ Century Texts. Reference is made to texts on justices of the peace by Fitzherbert (1538) ${ }^{27}$ and Lambard (1581). ${ }^{28}$ Also, to the first text on criminal law by Staunford (1577) ${ }^{29}$ and well as to texts by Pulton (1609-23), ${ }^{30}$ Dalton (1618-1746), ${ }^{31}$ Coke (1628-41) ${ }^{32}$ and Hale (published in 1736 but written in the 1670 's) $;^{33}$

- $\quad \mathbf{1 8}^{\text {th }}$ Century Texts. Reference is made to texts by Hawkins (1716-1824), ${ }^{34}$ Burn (1755 -1869) ${ }^{35}$ and Blackstone (1765-9). ${ }^{36}$ Also, to Buller's text on Nisi Prius (1778); ${ }^{37}$

- $\quad \mathbf{1 9}^{\text {th }}$ Century Texts. Reference is made to texts by East (1803), Russell (1819-1964), ${ }^{38}$ Archbold (1822-2014) ${ }^{39}$ Gabbett (1843), ${ }^{40}$ Harris (1881) ${ }^{41}$ and Stephen (1883). ${ }^{42}$ Also, to Selwyn's text on Nisi Prius (1869); ${ }^{43}$

- $\quad \mathbf{2 0}^{\text {th }}$ Century Texts. Reference is made to texts by Kenny (1902-66), ${ }^{44}$ Cross and Jones (1949), ${ }^{45}$ Smith and Hogan (1965) ${ }^{46}$ and Glanville Williams (1961). ${ }^{47}$

${ }^{20}$ W Hughes, Grand Abridgment of the Law (Henry Twyford et al, 1660-3). This has been reprinted by the Law Book Exchange.

${ }^{21} \mathrm{H}$ Rolle, Abridgment des plusieurs Cases et Resolutions del Common Ley (A Crooke et al, 1668).

${ }^{22}$ W Sheppard, Grand Abridgment of the Common and Statute Law of England (sold by George Sawbridge et al, 1675).

${ }^{23}$ W Nelson, Abridgment of the Common Law (E \& R Gosling, 1725-6). This has been reprinted.

${ }^{24}$ E Viner, A General Abridgment of the Law and Equity (GCJ \& J Robinson, $1^{\text {st }}$ ed, 1741-57, $2^{\text {nd }}$ ed 1791). This has been reprinted by the Law Book Exchange (there is also a $\mathrm{CD}$ with wordsearch).

${ }^{25}$ M Bacon, New Abridgment of the Law ( $1^{\text {st }}$ ed, 1736. $5^{\text {th }}$ ed (H Gwillim (ed), 1798), last ed ( $7^{\text {th }}$ ed), 1832).

${ }^{26} \mathrm{~J}$ Comyns, Digest of the Laws of England ( $1^{\text {st }}$ ed, 1762-7, last ed, 1822). See also J Lilly, Practical Register (1 $1^{\text {st }}$ ed, 1719; $2^{\text {nd }}$ ed, with supplement, 1745).

${ }^{27}$ A Fitzherbert, The New Boke of Justices of the Peas (London, 1538, rep Professional Books, 1972). This was a translation of $L^{\prime}$ 'Office et Auctoryte des Justyces de Peas, printed earlier that year. Fitzherbert's text was later edited by Richard Crompton, see R Crompton, $L$ 'Office et Auchtoritie de Justices de Peace (1584, rep Professional Books).

${ }^{28}$ W Lambard, Eirenarcha (1581) This has been reprinted by the Law Book Exchange. The last edition was in 1619.

${ }^{29}$ W Staunford, Les Plees del Coron (Richard Tottell, $1^{\text {st }}$ ed, 1557, last ed, 1607). This has been reprinted by the Law Book Exchange.

${ }^{30}$ F Pulton, De Pace Regis et Regni (printed for the Companie of Stationers, 1609). The last edition ( $4^{\text {th }}$ ed) was in 1623 . The first edition has been reprinted by the Law Book Exchange.

${ }^{31}$ M Dalton, The Countrey Justice (Societie of Stationers, $1^{\text {st }}$ ed, 1618; $2^{\text {nd }}$ ed, 1619; last ed, 1746). The first edition has been reprinted by the Law Book Exchange.

${ }^{32}$ E Coke, Institutes of the Laws of England (W Clarke \& Sons, London, last ed, 1824, which is cited).

${ }^{33} \mathrm{M}$ Hale, The History of the Pleas of the Crown (printed for E \& R Nutt \& R Gosling, 1736). Assault and battery are not considered in M Hale, Pleas of the Crown (London, 1685).

${ }^{34}$ W Hawkins, A Treatise on Pleas of the Crown (E \& R Nutt \& R Gosling, Savoy (1 $1^{\text {st }}$ ed 1716-21; last ed ( $8^{\text {th }}$ ed), 1824).

${ }^{35} \mathrm{R}$ Burn, The Justice of the Peace and Parish Officer ( $1^{\text {st }}$ ed, 1755; last ed 1869).

${ }^{36}$ W Blackstone, Commentaries on the Laws of England (Oxford, Clarendon Press, $1{ }^{\text {st }}$ ed, 1765-9, University of Chicago Press rep 1979). The final edition of Blackstone was effectively that of HJ Stephen, New Commentaries on the Laws of England (4 vols, 1841-5), although much of the input was of the latter.

${ }^{37}$ F Buller, An Introduction to the Law relative to Trials at Nisi Prius $\left(5^{\text {th }} \mathrm{ed}, 1788\right)$. The first edition of this work was in 1772, the last in 1817. Buller's work appears to have been based on that of H Bathurst, An Introduction to the Law relative to Trials at Nisi Prius $\left(1^{\text {st }}\right.$ ed, $1767 ; 2^{\text {nd }}$ ed, 1768).

${ }^{38}$ EH East, $A$ Treatise of the Pleas of the Crown (only ed, 1803). Also, WO Russell, A Treatise on Crimes and Misdemeanors $\left(1^{\text {st }}\right.$ ed, 1819). The last edition of Russell (the $12^{\text {th }}$ ed) was in 1964, edited by JWC Turner.

${ }^{39}$ W Archbold, Criminal Pleading, Evidence and Practice (Sweet \& Maxwell, 2014). See also JF Archbold, A Summary of the law relative to Pleading and Evidence in Criminal Cases (1822, being the $\left.1^{\text {st }} \mathrm{ed}\right)$.

${ }^{40} \mathrm{~J}$ Gabbett, A Treatise on the Criminal Law (Dublin, 1843).

${ }^{41}$ SF Harris, Principles of the Criminal Law (Stevens \& Haynes, 1881). The last edition was in 1973.

${ }^{42}$ JF Stephen, A Digest of the Criminal Law (Macmillan \& Co, ${ }^{\text {rd }}$ ed, 1883). JF Stephen, A History of the Criminal Law of England (Macmillan $\& \mathrm{Co}, 1883)$ does not deal with assault and battery.

${ }^{43}$ W Selwyn, Abridgment of the Law of Nisi Prius (Stevens \& Sons, $13^{\text {th }}$ ed (1869), the last edition). The first edition of this work was in 1806-8.

${ }^{44}$ CS Kenny, Outlines of Criminal Law (Cambridge UP, $1^{\text {st }}$ ed, 1902; $2^{\text {nd }}$ ed, 1904). See also JWC Turner, Kenny's Outlines of Criminal Law $\left(19^{\text {th }}\right.$ ed, 1966, last edition).

${ }^{45}$ R Cross \& PA Jones, An Introduction to Criminal Law (2 ${ }^{\text {nd }}$ ed, 1949). The $1^{\text {st }}$ ed was in 1948.

46 JC Smith \& B Hogan, Criminal Law (1st ed, 1965). 
Finally, reference is made to Halsbury ${ }^{48}$ and to Blackstone's Criminal Practice (2013) ${ }^{49}$ as well as to a plethora of modern texts on criminal law. ${ }^{50}$ Where appropriate, reference is also made to articles concerning assault and battery.

\section{Roman Law ${ }^{51}$}

Prior to discussing the position of battery (wounding) under Anglo-Saxon law, brief mention may be made of the position under Roman law since it was later to surface in English law. Under later Roman law, violence against the person was not just a criminal offence in various instances. It was also a tort. That is, a civil wrong (injuria) ${ }^{52}$ one which also covered defamation. ${ }^{53}$ Thus, Prichard stated:

Iniuria, as a specific wrong, was, in fact, any wilful violation of the right of a freeman to safety and reputation. The possible wrongs were very wide, for iniuria included not merely assault, but also defamation...The following examples of iniuria are found in the Institutes [of Justinian]: ${ }^{54}$ wounding or beating with a fist or a club...composing or publishing defamatory writing or verses.... and an attempt upon chastity... ${ }^{55}$ The delict was developed gradually by the praetor from crude 'tariff' rules for assaults. The remedies given by the Twelve Tables ${ }^{56}$ were: for maimed limbs, retaliation; for broken bones, a penalty of 300 asses, if the person injured was a freeman, 150 if a slave; for other injuries, 25 asses. ${ }^{57}$

Given that the grossest insult could be atoned for by paying 25 asses under the Twelve Tables (a small sum), this brought the law into dis-repute. ${ }^{58}$ Prichard continued:

The praetor accordingly introduced the actio iniuriarum, under which the plaintiff was allowed to fix his own damages, the judge having power to reduce them if he thought them excessive, by virtue of the condemnatio clause which instructed him to condemn for what should seem fair and just (bonum et aequum). This continued to be the practice at the time of Justinian, the damages being calculated after

${ }^{47}$ G Williams, The General Part (1961).

${ }^{48}$ Halsbury, Laws of England (5 $5^{\text {th }}$ ed, with updates).

${ }^{49}$ Blackstone's Criminal Practice 2013 (eds. A Hooper \& D Ormerod)('Blackstone CP'). See also Archbold, Magistrates Courts Criminal Procedure ('Archbold Procedure').

${ }^{50}$ See, for example: (a) C McAlhone \& R Huxley-Binns, Criminal Law. The Fundamentals (3rd ed, 2013); (b) MJ Allen, Textbook on Criminal Law (12 ${ }^{\text {th }}$ ed, 2013); (c) A Ashworth \& J Horder, Principles of Criminal Law ( $7^{\text {th }}$ ed, 2013); (d) R Card et al, Criminal Law (20 ${ }^{\text {th }}$ ed, 2012); (e) CMV Clarkson \& HM Keating, Criminal Law, Text and Materials ( $7^{\text {th }}$ ed, 2010); (f) C Elliott \& F Quinn, Criminal Law ( $8^{\text {th }}$ ed, 2010); (g) R Heaton, Criminal Law ( $2^{\text {nd }}$ ed, 2006); (h) J Herring, Criminal Law ( $8^{\text {th }}$ ed, 2013); (i) M Jefferson, Criminal Law (9 $9^{\text {th }}$ ed, 2009); (j) Lacey, Wells \& Quick, Reconstructing Criminal Law. Text and Materials ( $\left.{ }^{\text {th }} \mathrm{ed}, 2010\right) ;(\mathrm{k}) \mathrm{J}$ Loveless, Complete Criminal Law. Text. Cases and Materials ( $3^{\text {rd }}$ ed, 2012); (1) N Padfield, Criminal Law ( $7^{\text {th }}$ ed, 2010); (m) A Reed \& B Fitzpatrick, Criminal Law (4 ${ }^{\text {th }}$ ed, 2009); (n) AP Simester, Simester \& Sullivan's Criminal Law: Theory and Doctrine ( $5^{\text {th }}$ ed, 2013); (o) D Ormerod, Smith \& Hogan's Criminal Law (13 ${ }^{\text {th }}$ ed, 2011); (p) DJ Baker, Glanville Williams Textbook of Criminal Law $\left(1^{\text {st }} \mathrm{ed}, 1978,3^{\text {rd }} \mathrm{ed}, 2012\right) ;(\mathrm{q})$ MJ Allen \& S Cooper, Elliott \& Woods' Cases and Materials on Criminal Law (1 $1^{\text {th }}$ ed, 2013); (r) M Molan, Cases and Materials on Criminal Law ( $4^{\text {th }}$ ed, 2008); (s) J Martin \& T Storey, Unlocking Criminal Law ( $3^{\text {rd }}$ ed, 2010); (t) P Hungerford-Welch \& A Taylor, Sourcebook on Criminal Law (1997); (u) M Molan et al, Bloy \& Parry's Principles of Criminal Law (4 $4^{\text {th }}$ ed, 2000); (v) W Wilson, Criminal Law (4 $4^{\text {th }}$ ed, 2011); (w) J Cooke, Law of Tort (11th ed, 2003).

${ }^{51}$ See generally AM Prichard, Leage's Roman Private Law (3 ${ }^{\text {rd }}$ ed, 1961), WW Buckland, A Text-Book of Roman Law from Augustus to Justinian (Cambridge UP, 1921), WW Buckland \& AD McNair, Roman Law and Common Law: A Comparison in Outline (Cambridge UP, $2^{\text {nd }}$ ed, 1952) and TC Sandars, The Institutes of Justinian (Longmans, 1962 impression). See also Stephen, History, n 42, vol 1, ch 2 and OF Robinson, The Criminal Law of Ancient Rome (John Hopkins UP, 1995), pp 48-51 (he discusses the difference between vis and injuria).

${ }_{52}$ Prichard, n 51, p 416 'Justinian says that the term injuria has several meanings - (i) any illegal act. (ii) the wrong done by a judge who pronounces an unjust sentence. (iii) an act implying dolus or culpa, as under the Lex Aquila. (iv) an insulting act, one that is primarily injurious to a man's dignity.'

${ }_{53}$ Anglo-Saxon law seems to have treated defamation (public slander) as a separate crime (see n 84). For Bracton (c. 1240) see n 145.

${ }^{54}$ Justinian (483-565) Byzantine emperor from 527-65, ordered the codification of Roman law (Corpus Juris Civilis) of which the Institutes (Institutiones Justiniani), form part. See Institutes, Title 4 (De Injuriis), for which see Sandars, n 51, pp 418-23.

${ }^{55}$ Later manifested, in English law, in the form of indecent assault.

${ }^{56}$ The Twelve Tables comprised a code of ancient Roman law said to have been promulgated c. 449 BC. See also Sandars, n 51, pp xiii-xvii. Buckland, n 51, p 585 'The XII Tables contained provisions against a certain number of forms of insult, probably only assaults [i.e. batteries], usually subjecting them to a fixed money penalty.'

${ }^{57}$ Prichard, n 51, pp 417-8.

${ }^{58}$ Buckland \& McNair, n 51, pp 378-9, 'The delict of iniuria ... originally limited to provisions in the XII Tables for fixed penalties for assaults [i.e. batteries], called iniuriae, these being no doubt the only kind of insult to which a primitive people is sensible, it was first modified, though not extended, by the praetor, who substituted penalties assessed by the court for the ancient fixed penalties which had become derisory with the change in value of money.' Also, p 381 'Some forms of injuria were also criminal from early times, and it seems that in later law all forms of it were. It does not appear that the principles were in any way different from those of the civil forms.' 
considering the nature of the iniuria, the character of the person injured and the surrounding circumstances generally.

In particular, the damages might be greatly augmented if the wrong amounted to that species of iniuria which was known as atrox. In the case of atrox iniuria it normally happened that the praetor indirectly decided the amount of the penalty when he fixed the bail (vadimonium); for the plaintiff would take this as the sum to claim, and the iudex [judge], though not bound to allow the full amount, would do so in deference to the praetor. An insult might be atrox - (1) Ex facto (or ex re), by reason of the nature of the act, as where a man was beaten with clubs. (2) Ex loco vulneris, because of the part of the body injured, e.g. the eye...(3) Ex loco, by reason of the place where the injury was done, as in the forum or a theatre. (4) Ex persona, by reason of the dignity of the person subjected to the injury; e.g. where a magistrate or senator was attacked.

The actio iniuriarum lay against not only principals but accessories to the act, all for the full amount...It was barred by dissimulatio, i.e. a man who failed to show immediate resentment was taken to acquiesce in the wrong done to him and could not afterwards bring the action. The actio iniuriarum was in factum, involving infamia and had to be brought within a year. Finally, in most cases of iniuria the person wronged could elect between the civil action and a criminal prosecution; e.g. under the lex Cornelia (c. $81 \mathrm{BC}){ }^{59}$ and under this law a distinct civil remedy came to be developed (in addition to the praetorian actio iniuriarum) for cases where one was beaten or struck or one's house was broken into. This action was not barred in a year. ${ }^{60}$ (wording divided for ease of reference)

It is unclear the extent to which Roman law prevailed after the Romans quit Britain in AD 410 (or thereabouts) until the issue of the first of the Anglo-Saxon laws still extant - that of Aethelbert (issued c. 597 at the earliest, see 4). However, it is likely that the above provisions of Roman law prevailed for quite some time. Further, it may be noted that various features contained in Roman law continued under Anglo-Saxon law ${ }^{61}$ - such as a tariff system of fines and that of punishing aggravated battery with a higher fine.

\section{Anglo-Saxon Law ${ }^{62}$}

Few Anglo-Saxon laws have come down to us and, as Pollock and Maitland pointed out, those which have, are likely to be mere 'superstructures on a much larger base of custom. ${ }^{63}$ That said, in respect of wounding (battery), ${ }^{64}$ the following may be noted:

\section{(a) Aethelbert (c. 558-616)}

The earliest extant code appears to be that of Aethelbert, king of Kent (there are variants to the spelling of his name). ${ }^{65}$ When it was issued is unclear. However, it seems likely this was between AD 597-616. The code ${ }^{66}$ comprises some 90 provisions. The majority of the crimes reflected in them comprised battery in some form whether it be murder, the rape of a woman or wounding - without any categorisation or specific legal distinction

\footnotetext{
59 The Lex Cornelia de Injuriis provided a penalty for injury to the person. See generally, Buckland, n 51, pp 585-8. See also A Watson (ed), The Digest of Justinian (University of Pennsylvania Press, 1985), vol 4, p 297 containing the Digest 47.10 .35 and 45.

${ }^{60}$ Prichard, n 51, pp 418-9. The Roman punishment for being beaten or struck in one's house was not dissimilar to the Anglo-Saxon hamsocn (an attack on a man's house). See also n 132. It may be noted that injuria could be direct or indirect, see e.g. Buckland, n 51, p 586. See also Digest, n 59, 47.10.11.1, which cites Ulpian, Edict, bk 57 'Not only he is liable for affront who actually inflicts it, that is, who inflicts the blow, but also he who deliberately brings it about or takes steps to ensure that a cheek be struck by a fist.'

${ }^{61}$ P Wormald, The First Code of English Law (Canterbury Commemoration Society, 2005), pp 15-7 also suggested that the law of Aethelbert would likely have had reference to earlier Roman law. For the Roman law on punishing atrox injuria, see Buckland, n 51, p 587 'In general the praetor fixed his maximum claim by a taxation, which the iudex [judge] could cut down. In atrox iniuria the praetor fixed the maximum, usually at a higher rate, and the iudex did not interfere with it.'

62 See generally, ns $6 \& 61$ (Wormold). See also Stephen (History), n 42, vol 1, ch .3.

${ }^{63}$ F Pollock \& FW Maitland, The History of English Law (Cambridge UP, 1968) ('P \& M'), vol 1, p 27. They (p 38) summarised the content of Anglo-Saxon laws generally as follows: 'In so far as we can trust the written laws, the only topics of general importance were manslaying, wounding, and cattle stealing.' Also, p 43 'The only substantive rules that are at all fully set forth have to do with offences and wrongs, mostly those which are of a violent kind, and with theft, mostly cattle lifting.' See also Stephen, (History), n 42, vol 1, ch 3.

${ }^{64}$ There would seem to be no evidence that assault (threatened battery or wounding) was punished by the criminal law.

${ }^{65} \mathrm{P} \& \mathrm{M}, \mathrm{n}$ 63, vol 2, p 27 'We have in the first place the considerable series of laws and ordinances of Saxon and English princes, beginning with those of Aethelbert of Kent, well known to general history as Augustine's convert, which are of about the end of the sixth century.'

${ }^{66}$ FW Maitland, The Collected Papers of Frederick William Maitland (Cambridge UP, 1911), vol 2, p 420 'To call this brief tariff a code may seem strange, but there are not wanting signs that the wise men of Kent are committing to writing as much of their traditional law as they can remember in the form of abstract propositions.'
} 
being made between them. ${ }^{67}$

- In respect of wounding a person, by way of punishment, a tariff of fines was laid down. ${ }^{68}$ One which was very specific as to the nature of the wound. ${ }^{69}$ See Appendix A;

- Compensation was also payable in the case of dis-figurements ${ }^{70}$ as well as for bruising (one suspects of a major sort). ${ }^{71}$ Compensation for the victim's medical treatment was also payable. ${ }^{72}$

As to why those particular injuries were selected for criminal punishment, most seem to relate to injuries which would have resulted in reducing the fighting capacity of a man or his ability to sustain himself (something which became a separate crime under English law, that is, mayhem). ${ }^{73}$ The following may also be noted:

- The level of fine (composition) imposed often depended upon the: (a) status of the victim; ${ }^{74}$ and (b) location (for example, if the battery occurred on the king's premises, the fine was the greater). ${ }^{75}$ This was similar to the position under Roman law; ${ }^{76}$

- These fines in Aethelbert's time (the $6^{\text {th }}$ century) would have been paid to the victim. However, it is likely that - by the $10^{\text {th }}$ century - they went to the king or to the church, ${ }^{77}$ as the latter began to appreciate that criminal punishments could be a useful 'revenue raising' device.

Finally, the purposive element of punishing these batteries - these 'breaches of the peace' - was that they were regarded not only as a personal wrong but also a wrong against the king himself (in effect, a breach of allegiance against his 'peace' or authority). ${ }^{78}$ The intent of the king (and his judges) in punishing them was not only to avoid people resorting to private redress by way of self-perpetuating feuds and retaliation ${ }^{79}$ but also to preserve overall public harmony - one on which the king's own rule was dependent. It may be noted that this tariff system

${ }^{67}$ See Attenborough, n 6, pp 5-17 and Thorpe, n 6, pp 1-10 (for the laws). See also Wormald, n 61. The other provisions of Aethelbert's code mainly covered theft, robbery and trespass.

${ }^{68} \mathrm{P} \& \mathrm{M}, \mathrm{n}$ 63, vol 2, p 47. 'A freeman's life has a regular value set upon it, called wergild, literally man's price or man-payment, [also called blood money] or oftener in English documents wer simply; moreover, for injuries to the person short of death there is an elaborate tariff.' Maitland, n 66, p 427 'We have called the written laws 'tariffs'. They prescribe in great detail the various sums of money which must be paid by wrong-doers. There are payments to be made to the injured person or the kinsfolk of the slain man; there are also payments to be made to the king, or some other representative of the tribe or nation.'

${ }^{69}$ Ibid, p 53. 'Injuries and assaults to the person were dealt with by a minute scale of fixed compensations, which appears, though much abridged, as late as the Anglo-Norman compilations.' Wormald, n 61, p 14 'All conceivable parts of one's body had their specific value.'

${ }^{70}$ Attenborough, n 6, p 11 'For the slightest disfigurement, 3 shillings, and for a greater 6 shillings [shall be paid as compensation].'

${ }^{71}$ Ibid, p 13 'If it leaves a bruise, 1 shilling [shall be paid as compensation]. If a blow is received with uplifted hand, a shilling shall be paid. If it leaves a black bruise [showing] outside the clothes, 30 sceattas shall be paid as compensation. If it [the bruise] is under the clothes, 20 sceattas shall be paid as compensation for each [bruise].' Wormald, n 61, p 11 'shillings and scaetta were weights of gold or silver which might take the form of a coin, of other precious objects, or of metal weights like those used on scales in pre-electronic days.' Also, p 176 'The sceatt[a] was the predecessor of the penny...'.

${ }^{72}$ Ibid. 'If a man received medical treatment, 30 shillings shall be paid as compensation.'

${ }^{73}$ In Anglo-Saxon law and the Laws of Henry I, there is a great emphasis on teeth (and which ones). Why? Bracton seemed to think it was due to the fact that teeth were important for fighting - although one suspects it was also due to the fact that a person in those times without teeth would have difficulty feeding himself and, thus, his life expectancy would be much reduced.

${ }^{74}$ For example, if a freeman was slain it was 50 shillings to the king, but if a smith (or a messenger) belonging to the king, then it was the 'ordinary' wergild. If a man slew another the ordinary wergild was 100 shillings, but if the victim was the dependent of a commoner, then 6 shillings and if a servant (who has committed no offence) his full value. See Attenborough, n 6, pp 5-6. If a man slew a laet of the best class, the fine was 80 shillings, if of the second class it was 60 shillings, if of the third class, it was 40 shillings. See also Wormald, $\mathrm{n} 61$, p 14 'the amount of compensation due was determined by the sufferer's status.'

${ }^{75}$ Thus, if a man slew another on the king's premises, the fine (compensation) was 50 shillings, but only 12 shillings if it occurred on a nobleman's premises.' See also Wormold, n 61, p 14 (who also noted that the integrity of a man's home (enclosure) and that marriage was upheld on the same basis as life and limb).

${ }^{76}$ See Prichard (see 3)(re atrox).

${ }^{77}$ Wormald, $\mathrm{n}$ 61, pp 14-5 'By the tenth century, royal action is the norm, and bot is payable not to victims, and/or their families but to the king, or God (i.e. the Church). We may by that stage, if not under Aethelberht, think in terms of 'Crime' and 'Punishment.' Bot was the compensation payable for an injury or wrong and it was by way of a peace offering, see JRC Hall, Concise Anglo-Saxon Dictionary ( $4^{\text {th }}$ ed, 1975 rep).

${ }^{78}$ P \& M, n 63, vol 2, p 45 'Breach of the king's peace was an act of personal disobedience, and a much graver matter than an ordinary breach of public order; it made the wrong-doer the king's enemy.'

${ }^{79}$ Wormald, n 61, pp 12-3 'monetary payment... which put an end to a feud.' See also Attenborough, n 6, p 39 referring to the laws of king Ine (king of Wessex, 688-725), 'If anyone exacts redress, before he pleads for justice, he shall give up what he has taken, and pay as much again, and 30 shillings compensation.' See also Robertson, n 6, p 11 (referring to the laws of king Edmund (936-46) re vendettas) 'The authorities must put a stop to vendettas.' 
was not restricted to England. Indeed, it likely was closely allied to Germanic tariffs, for example Old Frisian tariffs. The nature of these - and as to why the tariff emphasised hair pulling, pouring a liquid over a person etc. is discussed in Appendix F.

\section{(b) Ine (688-725) \& Alfred (871-99)}

The laws of king Ine (king of Wessex between 688-725) fined fighting (this later seems to have become known as fightwite) ${ }^{80}$ and the laws of Alfred (king of Wessex between 871-99) which were, possibly, issued in 892-3 (or earlier) ${ }^{81}$ made further provisions in respect of wounding. ${ }^{82}$ In this, the following may be noted:

- The laws of Alfred, basically, followed those of Aethelbert in respect of the tariff system (see (a)). However, Alfred's laws often increased the monetary sum payable as well as specified in even greater detail, the type of wound. ${ }^{83}$ See Appendix A;

- Under the laws of Alfred (if not before) public slander was dealt with as a separate offence ${ }^{84}$ something which happened in later times under the English criminal law; ${ }^{85}$

- Fighting - as well as the drawing of a weapon in certain places - was also punished. ${ }^{86}$

\section{(c) Edward the Confessor (1042-66)}

Subsequent to the laws of Alfred were those of king Edward the Elder (900-925?) and Ethelstan (925-39) as well as of other sovereigns. ${ }^{87}$ These tended to deal more with theft, suretyship etc. However, there is nothing to suggest that they were not incremental to the laws of Alfred and his predecessors.

- Finally, one arrives as the (alleged) laws of Edward the Confessor (1042-66). ${ }^{88}$ They do not make (it appears) any amendment to the prior tariffs for wounding laid down by Aethelbert and Alfred. Thus, it is likely that these earlier laws imposing a tariff of fines for battery applied up to the time of the Norman Conquest in 1066, at least. Indeed, probably up to c.1189 (at least), see 5;

- Further, it may be noted these Anglo-Saxon fines comprised both a part of criminal law (as a wite) as well as part of civil law (as bot) ${ }^{89}$ - since compensation was payable both to the king (as a wite) and to

\footnotetext{
${ }^{80}$ Attenborough, n 6, p 39 'If anyone fights in the king's house, he shall forfeit all his property, and it shall be for the king to decide whether he shall be put to death or not. If anyone fights in a monastery, he shall pay 120 shillings compensation. If anyone fights in the house of an ealdorman or of any other distinguished councillor, he shall pay 60 shillings compensation [to the householder] and he shall pay another 60 shillings as a fine. If, however, he fights in the house of a taxpayer or of a gebur, he shall pay 120 shillings as a fine, and 6 shillings to the gebur. And even if it [the fight] takes place in the open, a fine of 120 shillings shall be paid. If, however, two men quarrel over their cups and one endures it patiently, the other [who has recourse to violence] shall pay of a fine of 20 shillings.' 'Gebur' was (probably) a reference to one who did not possess a property of his own, see Attenborough, n 6, p 184. It would seem that the fine for fighting later became known as ' $f$ ihtwite', see Downer, n 8, p 337.

${ }^{81}$ Ibid, p 35.

${ }^{82}$ Stephen (History), $\mathrm{n} 42$, vol 1, p 56 'The crime of inflicting bodily harm is described in some of the laws with almost surgical minuteness. Of the seventy-seven laws of Alfred, no less than thirty-four define the different injuries which may be inflicted by unlawful violence.'

${ }^{83}$ Ibid, p 93 'If one man damages the tendons in another's neck, and wounds him so severely that he has no control over them, but [if] nevertheless he continues to live so wounded, 100 shillings shall be given to him as compensation, unless the councillors award him a juster and a greater sum.'

${ }^{84} \mathrm{Ibid}, \mathrm{p} 77$ 'If anyone utters a public slander, and it is proved against him, he shall make amends on no lighter terms than the excision of his tongue, [with the provision that] it shall not be ransomed at a cheaper price than [its value], estimated according to the [man's] wergild. Also, $\mathrm{p}$ 21 'If one man calls another a perjurer in a third man's house, or accosts him abusively with insulting words, he shall pay one shilling to him who owns the house, 6 shillings to him he has accosted, and 12 shillings to the king.'

${ }^{85}$ There was scandalum magnatum (slander of great men) as well as criminal libel (both these common law offences have been abolished).

${ }^{86}$ Attenborough, n 6, p 69 'If anyone fights or draws his weapon in the king's hall, and [if he] is arrested, it shall be for the king to decide whether he shall be put to death, or permitted to live, in case the king is willing to forgive him.' Ibid, $\mathrm{p} 73$ (fighting or drawing a weapon in the presence of the archbishop) and $\mathrm{p} 81$ (fighting or drawing a weapon at the meeting of ealdormen or commoners). For the earlier law of Ine on this, see $\mathrm{p}$ 39. Prior legislation of king Hlothhere (king of Kent, 673- 685/ 6) and of king Eadric (king of Kent, 685-6) had punished the drawing of a weapon when men were drinking. Attenborough, n 6, p 21 'If, where men are drinking, a man draws his weapon, but no harm is done there, he shall pay a shilling to him who owns the house, and 12 shillings to the king.'

${ }^{87}$ See generally, Attenborough, n 6, pp 102 et seq.

${ }^{88}$ See O'Brien, $\mathrm{n} 7$.

${ }^{89}$ There was, in any case, no meaningful distinction. P \& M, n 63, vol 2, p 449 'On the eve of the Norman Conquest what we may call the criminal law of England (but it was also the law of 'torts' or civil wrongs)...'
} 
the victim (as bot). ${ }^{90}$ That said, it is likely that the sovereign (or the church) was, by the $10^{\text {th }}$ century, claiming most (if not all) that sum. ${ }^{91}$

In conclusion, in Anglo-Saxon times, battery was punished by way of a tariff of fines, depending on the nature of the wound or the bruise or blow. A fine was also payable for fighting as such. However, there seems to have been no criminal penalty for mere assault (i.e. a threatened battery). This is understandable since it was a 'rude' age, and only a more civilised society would make the latter a crime.

\section{Henry I (1100-35) - Glanvill (c. 1189)}

It is likely that the Norman Conquest did not change the Anglo-Saxon criminal law on wounding. Evidence of this would appear to be clear from the text - the Laws of Henry I. ${ }^{92}$ This text was probably issued c. $1113-8$ and although it does not comprise a statement of the 'laws' as such (being a legal text) - it probably does reflect the legal position of that time fairly accurately. ${ }^{93}$

\section{(a) Henry I (1100-35)}

The Laws of Henry I are of considerable interest since - as well as devoting a considerable number of provisions to the law of homicide - they contain a detailed tariff of fines payable in respect of various designated batteries (see Appendix A). ${ }^{94}$ The tariff, clearly, seems to have been derived from Anglo-Saxon law - notably, the laws of Alfred (871-99)(see 4(b)). ${ }^{95}$

- Blodwite \& Fightwite. What is an extension of Anglo-Saxon law (it seems) is that the Laws of Henry I made a distinction between blodwite (the fine payable to the king for drawing blood) ${ }^{96}$ and fi $[\mathrm{g}] \mathrm{hwite}$ (the fine payable to the king for fighting when blood was not drawn). ${ }^{97}$ The purpose of this distinction is unclear - it may have related to whom the fine was payable; ${ }^{98}$

- Self-Defence. A right of self-defence was recognised 99 - even to the point of killing another - ${ }^{100}$ and a servant could come to the aid of this lord. ${ }^{101}$ Further, self-defence could be exercised pre-emptively; ${ }^{102}$

\footnotetext{
${ }^{90}$ That is, bot to the victim and a wite (fine) to the king. See P \& M, n 63, vol 2, p 451. They also note that (in later Anglo-Saxon times) 'Criminal jurisdiction became a source of revenue; 'pleas' and 'forfeitures' were among the profitable rights which the king could grant to prelates and thegns....In [king] Cnut's day [he was king from 985 or 995-1035] the time had come when it was necessary and possible for him to assert that certain pleas, certain crimes, were specially his own; that the cognizance and profits of them belonged only to him or those to whom he had granted an unusual favour. We get our first list of what in later days are called the pleas of the Crown.'

${ }^{91}$ See $\mathrm{n} 77$.

${ }^{92}$ There are also the so-called Laws of William I (1066-87), see Robertson, n 6, p 259 which contain a fore-shortened tariff. Thus, 'If a man wounds another and has to pay compensation, he shall, in the first instance, pay the cost of his medical attendance. With regard to sarbot, that is [compensation] for a wound: If he is wounded on the face, on a part which is visible, for every inch 8 pence shall be paid in every case; if on the head or in any other place where it is hidden, for every inch 4 pence shall be paid in every case. And for each piece of bone drawn out of the wound 4 pence shall be paid in every case...If it happens that a man cuts off the hand or foot of another, he shall pay him (as compensation) half his wergild according to his inherited rank. For the thumb he shall pay him half the value of his hand; for the finger next to the thumb 15 shillings according to the English reckoning, that is 4 pence to the shilling; for the middle finger 16 shillings; for the ring-finger 17 shillings; for the little finger 5 shillings. For the nail if it is cut away from the flesh, 5 shillings [shall be paid], and for the nail of the little finger 4 pence.'

${ }^{93} \mathrm{P} \& \mathrm{M}, \mathrm{n}$ 63, vol 2, p 457 'The writer of the Leges Henrici represents the criminal law of his time as being in the main the old law, and we have no reason to doubt the truth of what he tells us.'

${ }^{94}$ See also Downer, $n$ 8, pp 293-303.

${ }^{95}$ See the references of Downer, $\mathrm{n} 8$, in the footnotes to his text, pp 293-303 where he cross-references some of the batteries to provisions in Alfred's laws some 200 years earlier.

${ }^{96}$ Downer, n 8, p 301 'Anyone who does an injury to another and draws blood shall pay compensation for this by the inch; for each inch five pence, when the injury is in a concealed place, and for each inch ten pence, when the injury is in a visible place; and no compensation shall be payable for wounds without blood and closed up.' Cf. p 299 'Anyone who strikes another so that he does not cause his blood to flow, shall in accordance with the law pay compensation for only three blows, however many blows he in fact gives him; he shall pay five pence for each blow, which makes a total of fifteen pence.' Also, 'Blodwite and fightwite are not both to be received for the same offence.' See also Hall, n 77 (definition of blodwite, a blood offering, penalty for bloodshed).

${ }^{97}$ Ibid, pp 299-303 (concerning striking without the drawing of blood). e.g. p 300, 'Anyone who strikes another so that he does not cause his blood to flow, shall in accordance with the law pay compensation for only three blows, however many blows he in fact gives him; he shall pay five pence for each blow, which makes a total of fifteen pence.'

${ }^{98}$ See Downer, n 8, App 3, pp 435-7. It is unclear whether blodwite existed under Anglo-Saxon law, see Ibid, pp 127, 145 \& 435,(see also O'Brien, n 7, p 74). Cf. FRP Akehurst, The Coutumes de Beauvasis of Phillipe de Beaumanoir (Univ of Pennsylvania Press, 1992), pp 304-5 (although these Coutumes are a later text (one of 1283), there is a difference in fines whether blood is shed or not. If shed, it was greater).

${ }^{99}$ Downer, $\mathrm{n}$ 8, p 259 'Anyone may defend himself, if someone attacks him, in every place and circumstance, except against his lord, who is to be borne with, not killed - a matter which we repeatedly suppose to be worth heeding continually and profitably'. Also, p 271 'If anyone in his
} 
- $\quad$ Accidental \& Negligent Batteries. It was not a crime where the battery (wounding) was accidental ${ }^{103}$ or negligent. ${ }^{104}$ However, compensation (civil, i.e. bot) was payable. And, where it was an accident, people were encouraged to seek (private) compensation without involving the royal courts. ${ }^{105}$

Thus, the law on battery by c. 1113 was really quite advanced, with the criminal law punishing intentional batteries (wounding) but the civil law awarding compensation when it was negligent or accidental. Also, an emphasis on the parties coming to terms without court involvement, at least, in the case of the latter. ${ }^{106}$

\section{(b) Glanvill (c. 1189)}

Some 70 years after the Laws of Henry I, the first text on English law appeared - Glanvill, A Treatise on the Laws and Customs of the Realm of England (c. 1189). It did not deal with battery (wounding) but only with a small list of crimes ${ }^{107}$ though it did note that:

Pleas are either criminal or civil. Some criminal pleas belong to the crown of the lord king, and some to the sheriffs of counties.

After listing pleas of the Crown (treason, arson, robbery etc.) it noted:

If lords [of the manor] fail to do justice, then sheriffs also have jurisdiction over brawling, beatings, and even wounding, unless the accuser states in his claim that there has been a breach of the peace of the lord king. 108

Thus, it seems clear that the king's courts avoided dealing with battery and wounding - not least since most such incidents were likely of a private nature and did not have wider public repercussions. Instead, these were dealt with by the lords of the manor in their courts leet and, if they failed to act, then at the sheriff's tourn. Only if the accuser alleged that the wounding caused a 'beach of the king's peace' did the royal courts become involved. Further, it is likely that - even at the level of the court leet or sheriff's tourn - in 1189, minor blows, bruises and woundings were not treated as a criminal offence at all. Pollock and Maitland thought not - although redress might have available in the local courts (i.e. courts baron) pursuant to a civil action. ${ }^{109}$ Pollock and Maitland

own defence presents a spear or sword or any weapons against his enemy, and the latter, blinded by a detestable lust to inflict injury, rushes upon it, he shall bear responsibility himself for whatever happens to him.'

${ }^{100} \mathrm{Ibid}, \mathrm{p} 277$ 'In the case of a person compelled by necessity to commit a slaying the wite will with justice remain unpayable, which is equally true of a person who commits a revenge-slaying in a feud.'

${ }^{101}$ Ibid, p 273 'Any person may aid his lord without incurring a wite if anyone attacks him...however due consideration shall be given to the matter in all cases.' See also $\mathrm{p} 257$. This seems to derive, at least, as far back as the Laws of king Alfred which indicated a man might fight on behalf of his lord if the latter was attacked, without incurring a vendetta. So too could a man so fight on behalf of one related to him by blood. See Attenborough, n 6, p 85.

${ }^{102}$ Ibid, p 261 'If a quarrel arises as a sudden dispute between any persons because of an acrimonious exchange of words or any provocative occurrences, as a result of which any of them draws his sword from its scabbard, no one is obliged to wait passively until the swordsman strike him.'

${ }^{103}$ Ibid, p 271 'If a person in the course of a game of archery or of some exercise kills anyone with a spear or as a result of some accident of this kind, he shall pay compensation to him...For it is a rule of law that a person who unwittingly commits a wrong shall consciously make amends.' Also, p 273 'No one is obliged to make amends for his own child whom he did not kill intentionally, neither by way of money compensation nor by physical mutilation.'

${ }^{104}$ Ibid, p 269 'persons whose weapons they are shall not carry them carelessly.' Also, p 271 'If anyone carries a spear on his shoulder, and someone is killed by it, compensation to the extent of his wergild shall be paid, without imposition of the wite.' However, 'If the point of the spear is carried before the eyes of the bearer, he shall pay the wergild of the dead man, and if he is accused of deliberate intention in the matter he shall take care to make denial by an oath equal in value to the amount of the wite; and in this way the wite shall not be payable.' Also, p 279 'If anyone suffers any injury or mischief through the sudden discharge of a bow or ballista or because of a mantrap, erected for the capture of wolves or some other animal, the person who set it up shall pay amends.'

${ }^{105}$ Ibid, p 283 'There are very many kinds of misfortune which occur by accident rather than by design and which should be dealt with by the application of mercy rather than by formal judgment.' Also, 'For it is a rule of law that a person who unwittingly commits a wrong shall wittingly make amends.'

${ }^{106}$ It is important to note that there was no clear distinction between criminal, and civil, law in Anglo-Saxon times, in any case.

${ }^{107}$ Glanvill, The Treatise on the Laws and Customs of the Realm of England (c. 1189)(Nelson, 1965). Book 14 dealt with criminal pleas and discussed, inter alia, (a) treason; (b) concealment of treasure trove; (c) homicide; (d) arson; (e) robbery; (f) rape; (g) falsifying.

${ }^{108} \mathrm{Ibid}, \mathrm{p} 4$ 4'Ad vice-comites etiam pertinet per defectum dominorum cognoscere de melletis, de verberibus, de plagis etiam nisi accusator adiciat de pace domini regis infracta.' For contra pacem, see Milsom, Historical Foundations of the Common Law (2 ${ }^{\text {nd }}$ ed, 1981), pp 404-5 and TFT Plucknett, A Concise History of the Common Law ( $5^{\text {th }}$ ed, 1956), pp 456-7.

${ }^{109}$ P \& M, n 63, vol 2, p 525. See also JB Ames, Lectures on Legal History and Miscellaneous Legal Essays (Havard UP), p 41 'In the popular courts slighter injuries were redressed; they were known as battery (not amounting to mayhem), injury to property, personal or real, and actions for goods carried off. In appeal of battery (i.e. wounding), mayhem, and imprisonment, the appellor recovers damages.' Ames also noted: 'There is no appeal...for a slight battery which is only a trespass.' 
stated:

What did men [do] before they had this action [i.e. a civil action for damages]? What did they in Glanvill's day? .... as to blows and bruises we take it that they sued for some pre-appointed bot [i.e. civil compensation] in the local courts. The king was not to be troubled with such trifles. ${ }^{110}$

Pollock and Maitland also cited the Laws of Henry I which (albeit they were issued earlier than Glanvill, being in c. 1113) suggest that a man seeking to claim compensation in respect of minor batteries (i.e. minor blows, bruises and small wounds) would be treated with contempt. ${ }^{111}$ Thus, the Laws of Henry I state:

In some places the person who has committed blodwite, that is, the shedding of blood, is alone held liable; in others, so also is the victim, lest anyone, because he acts with impunity, should become arrogant or lest anyone who has suffered an affront should become accustomed to the sordid receipt of compensation. ${ }^{112}$

In certain places, as we have said, the person who deals or is dealt a blow is liable, so that no one who commits a wrong with impunity should become arrogant and no one who has suffered an affront should become accustomed to the sordid receipt of compensation. Where one is unwilling, two persons do not come to blows. Every lawbreaker is brother to another. He who answers a fool according to his folly is like unto him. ${ }^{113}$

In conclusion, by c.1113, it would seem that the criminal law punished by way of fine:

(a) the infliction of wounds (generally only those more than 1 inch in length) as well as other specified injuries (the loss of a limb, an eye etc.) according to a detailed tariff (see Appendix A);

(b) fighting generally - whether it resulted in the loss of blood (blodwite) or not (fightwite)

but that it did not punish the infliction of lesser blows and bruises, nor assault. A further dis-incentive to battery was that - if a man wounded another - he also had to pay for his medical treatment. ${ }^{114}$ The above position as to battery probably prevailed until close to the time when Glanvill wrote (c. 1189).

\section{End of Anglo-Saxon Tariff System for Battery}

The Anglo-Saxon tariff for battery seems to have survived into the $12^{\text {th }}$ century - possibly, close to 1189 . However, for reasons not fully understood, there was something of a sea-change in criminal law, probably around the time that Glanvill was writing in $1189 .{ }^{115}$ The tariff system disappears.

- Why this is so is unclear. Pollock and Maitland ascribed it to the inability of persons to pay the requisite fines. ${ }^{116}$ If they are correct, the sovereign (and the Exchequer) had realised that a large number of people were avoiding criminal punishment through inability to pay and, thus, a new system was required;

\footnotetext{
${ }^{110}$ Ibid. This would have applied even more so in the case of assault, for which there appears to be no criminal penalty. The nearest to it appears to be a provision in the Laws of Henry I which states: 'If anyone leaps to arms and disturbs the peace of the house, but does not strike anyone, his liability shall be fixed at half the penalty.' See Downer, n 8, p 261.

${ }^{111}$ P \& M, n 63, p 526, 'In Leg, Henr. [i.e. the Laws of Henry I] 39.84, there are exceedingly curious passages which show that in the twelfth century the man who sued for a bot (compensation) when he had been beaten was treated with contempt. Some courts would in such a case exact a wite from the stricken as well as the stricker. This is justified by a batch of proverbs: 'Ubi unus non vult, duo non certant; et omnis unlaga frater est alterius; et qui respondet stulto iuxta stultitiam suam similis est eius.' (see translation in the text to n 113). The first of these phrases means that it takes two to make a quarrel. But at any rate it is dirty to ask bot for dry blows.'

${ }^{112}$ Downer, n 8, p 145.

${ }^{113}$ Ibid. p 261. These latter sayings were, presumably, common proverbs of that time, just as 'it takes two to make a quarrel' is today.

${ }^{114}$ See ns $72 \& 92$ (laws of William I). It was also said that Henry I (1100-35), in 1008, ordered felons to be hanged instead of their being able to settle by paying a fine. T Blount, $A$ Law Dictionary $\left(3^{\text {rd }} \mathrm{ed}, 1717\right)($ felony). This would have affected the tariff system.

${ }_{115}$ P \& M, n 63, vol 2, p 458 'Now in England this elaborate system disappears with marvellous suddenness. In brief it is this: (1) There are a few crimes with wide definitions which place life and limb in the king's mercy. (2) The other crimes are punished chiefly by discretionary money penalties which have taken the place of the old pre-appointed wites, while the old pre-appointed bot has given way to 'damages' assessed by a tribunal. (3) outlawry is no longer a punishment; it is a mere 'process' compelling the attendance of the accused.' P \& M then quote the Dialogue of the Exchequer (see text in 6).

${ }^{116}$ P \& M, n 63, vol 2, p 460. TFT Plucknett, Edward I and Criminal Law (Cambridge UP, 1960), p 79 'The speculation of Maitland was that our old legal system called for the payments of so many and such large sums of money that the whole system broke down because there were few who could raise them. This system spelt disaster to many people, especially the criminal, for it assumed that if he cannot or will not pay, then his life is forfeit.' See also A Harding, The Law Courts of Medieval England (1973), p 28.
} 
- There now developed a system in which the death penalty became prodigal. ${ }^{117}$ Also, the use of imprisonment as a punishment seems to have been much more common (as well as the franchising of prisons, which made money for the king). ${ }^{118}$

The new system of punishment was summarised in the Dialogue concerning the Exchequer (Dialogus de Scaccario) ${ }^{119}$ - which is thought to have been written c. 1189 by (possibly) Richard Fitznigel (also called Richard Fitzneal, c. 1130-98). ${ }^{120}$ It noted:

For whosoever is convicted of an offence against the king, is condemned according to the degree of his crime in one of three ways. For minor offences, he is condemned in all his moveable goods; for major offences he can be mulcted of all his immoveable property, his lands and rents; and for the greatest and most heinous crimes he may be condemned in life and limb. ${ }^{121}$

To call this the 'new feudal law', Maitland suggested was 'too simple' in some cases. ${ }^{122}$ However, as Plucknett stated 'there can be no doubt that events were moving in that direction.' ${ }^{123}$ This new system of punishment - as referred to in the Dialogue of the Exchequer - can be seen in the legal writings of Bracton (c. 1240), Britton (c. 1290) and Fleta (c. 1290) - the main legal texts in the $13^{\text {th }}$ century, ones that were also to be such through the Yearbook years (see 9). These are now considered.

In conclusion - probably around, or after, 1189 - the Anglo-Saxon tariff system of fines for fighting (fightwite) and wounding became transmuted into a less formulaic one. Also, an emphasis was placed on parties seeking a civil remedy when there was no breach of the peace (i.e. a real threat to the communal order).

\section{Bracton (c. 1240), Britton (c.1290) \& Fleta (c. 1290)}

\section{(a) Bracton}

Bracton, in his On the Laws and Customs of England (c.1240), considered various pleas of the Crown, including homicide and battery (wounding). The latter was now treated as a felony ${ }^{124}$ and so punishable with death. That said, this rarely occurred - imprisonment and fine being the normal form of redress. ${ }^{125}$

- In the case of wounding 'in breach of the peace', Bracton cited the standard form in which an appeal of wounding was couched in those times. ${ }^{126}$ A small treatise from 1274-5 provides a similar form; ${ }^{127}$

- Bracton also detailed the duty of the coroner to inspect the wound; ${ }^{128}$

\footnotetext{
${ }^{117}$ Under William I (1066-87), for the death penalty, there had been substituted blinding and castration (or having his hands cut off, as an alternative to the latter), see Robertson, n 6, pp 243, 251.

${ }^{118} \mathrm{P} \& \mathrm{M}, \mathrm{n}$ 63, vol 2, pp 516-8.

${ }^{119}$ See Richard, son of Nigel, The Course of the Exchequer (trans Johnson, Thomas Nelson, 1950). See also (for another translation) R Fitzneale, The Ancient Dialogue concerning the Exchequer (printed for J Worrall, 1758).

${ }^{120} \mathrm{P} \& \mathrm{M}, \mathrm{n}$ 63, vol 1, pp 161-2.

${ }^{121}$ See n 119, p 113.

${ }^{122}$ P \& M, n 63, vol 2, p 459, n 1. Cf. Coutumes de Beauvasis (1283), n 98, p 305 'according to the old law, if a person caused loss of limb to another, the same was done to him as he had done, hand for hand and foot for foot; but things are no longer done this way according to our custom, instead you have to pay a penalty... and serve a long prison term and make restitution for his losses to the injured party according to his condition and what he is, and according to the wealth of the perpetrator.' However, the tariff system long continued under early German law, see M Dobozy (trans), The Saxon Mirror (Sachsenspiegel, Univ. of Pennsylvania Press, 1999), p 98.

${ }^{123}$ Plucknett, n 116, p 80 'Maitland may be right in saying that this is 'too simple', in some cases at least; but there can be no doubt that events were moving in that direction. In the competition for such money as there was to be had, the Crown was a favoured competitor, even when it was ranged (as it was sometimes) against ecclesiastical or civic authorities.'

${ }^{124} \mathrm{P} \& \mathrm{M}, \mathrm{n}$ 63, vol 2, pp 462-3,70.

${ }^{125}$ Ibid, p 488.

${ }^{126}$ Bracton, n 10, vol 2, p 406 'A appeals B for that on such a day, as he was in the king's peace in such a place (or 'as he went in the king's peace along the king's highway between such a vill and such on such a day') before (or 'after') such a feast, in such a year and at such an hour, the said B came with his force and attacked him in breach of the king's peace, feloniously and in a pre-meditated assault [et assultu praemeditato fecit ei insultum], and dealt him such a wound in such a part [of his body] with such a kind of weapon. And that he did this wickedly and feloniously he offers to prove against him by his body or as the court may award.' The concept of pre-meditated assault was particularly cited in the case of forsteal (or lying in wait for someone) under Anglo-Saxon law, see P \& M, n 63, vol 2, pp 468-9. See also Downer, n 8, p 249 (the offence of forsteal occurs if someone attacks his enemy unexpectedly or lies in wait for him on the road and assaults him).

${ }^{127}$ JM Kaye, Placita Corone (Selden Society, 1966), p 2 (apel de paye. an appeal of wounding). It states that one Adam de B appeals Richard de $\mathrm{C}$ who came 'with drawn sword in his right hand... and gave him a wound in the right shoulder: two inches wide, three inches long, and even more in depth so far as could be seen, in one place and another; and when he had committed this felony he at once ran off.'
} 
- Bracton noted that an appeal of wounding could sometimes be avoided by general exceptions - such as he had previously explained in his text when he considered appeals of homicide. There, he had noted, there were various general exceptions common to all appeals. ${ }^{129}$ Thus, it might be alleged that the appeal was not brought according to due legal process - which form of process then Bracton referred to - including in respect of wounding. ${ }^{130}$

\section{(b) Bracton - Defences}

The Laws of Henry I recognised self-defence as a defence to battery. ${ }^{131}$ So did Bracton, who expressly mentioned it in the context of homicide and hamsocn (entering another's house in breach of the peace) and would have also included it (almost certainly, although he did not specifically mention it) in the context of wounding. ${ }^{132}$ Bracton also included as a defence the trifling nature of the wound (this appears to have included blows and bruises not leading to a wound). Bracton stated:

It may also be avoided by special exceptions, for it may be avoided because of the trifling nature of the wound ${ }^{133}$...We must also see in what part of the body the wound was made and with what weapons, whether with arms having ground blades [or] a club or a stone. Though clubs and stones are included in the term 'weapons', sharpened weapons, as a sword, a two-edged axe and the like, cause a wound, but clubs and stones cause bruises and contusions which cannot be deemed wounds in the sense that the matter may be brought to the duel (i.e. to trial by battle). ${ }^{134}$

It is understandable why Bracton would have sought to avoid the punishment for wounding (which was death) when the injury only a minor one. Further, Bracton also mentioned other exceptions to an appeal of wounding:

- Administration of Justice. Bracton indicated it was not a crime to put a person to death according to the due administration of justice. ${ }^{135}$ This was likely treated as a defence (justification) on the basis that it was the due punishment for a breach of a peace and not, thus, itself a breach of the peace;

- Disciplining a Pupil. Bracton indicated that it was not homicide if a master beat (verberat) a pupil who then died - providing the master had not exceeded the 'mean and measure' in so beating. ${ }^{136}$ The

\footnotetext{
${ }^{128}$ Bracton, n 10, vol 2, p 345 'This is their official duty. If one has been appealed of breach of the peace and wounding, the wound must first be viewed, and if it is a dangerous one and the appellee is present let him be arrested at once and kept in custody until it is clear whether the wounded man can recover or not. If he cannot and dies, let the appellee be kept in prison; if he recovers, let the appellee be attached by four or more pledges, according as the wound is serious or slight: if it is mayhem, by many pledges, that there may be good security; if the wound is slight, two pledges are sufficient...They ought to view the said wounds, measure their length and depth, ascertain in what part of the body they are, whether on the head or elsewhere, and by what weapons they were inflicted.'

${ }^{129}$ Ibid, p 393 'Some exceptions are common to all appeals, [others] are special, varying in accordance with the several kinds of appeals, as appeals of homicide, breach of the peace and wounding, breach of the peace, wounding and mayhem or robbery, breach of the peace, wounding and imprisonment, or of robbery alone, or for felonious arson in breach of the peace, or the rape of virgins in breach of the peace. Against each of these appeals there are exceptions special to each case.'

${ }^{130}$ Ibid, p 394. 'He to whom an injuria has been done ought to raise the hue at once, as soon as he can, and go with it to the neighbouring and nearer vills and there make known the wicked and wrongful acts that have been done... It suffices for suit if the evil deeds committed are immediately shown to the king or to the justices if they are present, and there he will be told to go to the sheriff and coroners...And let the sheriff and coroners cause all the words of the appeal, just as they are pronounced before them, to be enrolled in order, and the form of the appeal...If it [is] an appeal of breach of the peace and wounding, what kind of wounds they were, fresh or old, and in what part of the body and of what length and depth.'

${ }^{131}$ See $\mathrm{n}$ 99. See also P \& M, n 63, vol 2, p 490 'We may gather from a case which occurred in 1225 that a mayhem committed in self-defence was justifiable...'

${ }^{132}$ Bracton, n 10, vol 2, p 438 (homicide) 'he who kills a thief, either a day thief or a night thief, is not liable, [that is], if he could not otherwise escape danger; if he could he is liable.' Bracton (hamsocn), p 408 'where one defends himself against hamsocn, which [the English call] the entering of a house in breach of the peace, and the intruder is slain, he will be free of liability if he who killed could defend himself in no other way.' See also Downer, n 8, p 253.

${ }^{133}$ Ibid, p 408. If punished criminally at all, around 1240, 'minor acts of violence, brawls, affrays, bloodshed' would have been punished (by amercement) in local courts - such as courts leet at the sheriffs' tourn. See P \& M, n 63, vol 2, p 520.

${ }^{134}$ Since a felony was a crime that could be prosecuted by an appeal, that is, by an accusation in which the accuser must generally offer battle (see P \& M, n 63, vol 2, p 466), what Bracton was saying was that trivial batteries were not felonious. See p 407 'whether it is a wound or a scratch (sit plaga vel rifflura), in order to ascertain from the deed whether it is an injuria or a felony.' See also P \& M, n 63, vol 2, p 467-8 'In the department of violence to the person a line is drawn between the wound and the bruise; 'blind blows' which neither break bone nor draw blood are no sufficient foundation for a charge of felony.'

${ }^{135}$ Bracton, n 10, vol 2, p 340 'But if it is done from a love of justice, the judge does not sin in condemning him to death, nor in ordering an officer to slay him, nor does the officer sin if, when sent by the judge, he kills the condemned man. But both sin if they act in this way when proper legal procedures have not been observed.'

${ }^{136}$ Ibid, p 341 'if he was engaged in a lawful act, as where a master has flogged a pupil as a disciplinary measure...in the case of the master by not exceeding mean and measure [non excedendo modum] in the flogging of his pupil, liability is not imputed to him.'
} 
rationale for this was that a teacher was in loco parentis and (following Roman law) a father had a large degree of control over his family, including the right to administer correction within the family unit (which included servants and slaves). These would not have been treated as criminal (unless unreasonable) since they did not result in a 'breach of the peace' in the wider communal context. Also, such correction would have been treated as minor (unless unreasonable);

- Just War. Bracton indicated that it was not homicide to kill a person in a 'just' war. As will be noted later, the rationale was that the act was designed to prevent a 'breach of the peace' and that, when martial law applied, in any case, the courts were silent. ${ }^{137}$

In conclusion, the courts in the $13^{\text {th }}$ century seem to have been keen to avoid minor wounds from being subject to the royal courts (the penalty for wounding generally being death). ${ }^{138}$ Finally, it is likely that - up to the time of Bracton at least - the criminal law only punished intentional batteries. Not those arising from recklessness, negligence or accident, where civil redress might be available. ${ }^{139}$

\section{(c) Bracton \& Britton - Mayhem}

As well as dealing with breach of the peace by wounding, Bracton considered the aggravated offence of wounding, called mayhem.

- Mayhem comprised a crime where wounding rendered a person incapable of fighting; ${ }^{140}$

- Mayhem had its pre-cursor in the Roman atrox injuria (see 3) as well as the Anglo-Saxon tariff where certain wounds were more heavily punished because they rendered a man incapable of fighting. ${ }^{141}$

Britton (writing c. 1290, some 50 years after Bracton) also referred to mayhem. ${ }^{142}$ and - from his description of $\mathrm{it}^{143}$ - it seems clear that the royal courts were concerned only to punish as a felony the more severe forms of wounding as formerly described in the Anglo-Saxon tariff. ${ }^{144}$

\section{(d) Bracton - Civil Remedy}

Bracton noted that - in the case of breach of the peace by wounding - a civil remedy was also available. He stated:

In an appeal of breach of the peace and wounding and imprisonment, though the deed is criminal, the

\footnotetext{
${ }^{137}$ Ibid, p 342 'Homicide also occurs in war, and we must then ascertain whether the war is just or unjust. If it is unjust he who kills will be liable; if just, as a war in defence of the patria, he will not, unless he acts with evil intent.'

${ }^{138}$ That said, for battery, where a civil remedy was not elected, there was trial by battle and the lex talionis applied if the aggressor lost. Ames, n 109, p 47 'In the appeals for smaller injuries, battery, imprisonment, and mayhem the convicted appellee, although technically a felon, was not punished with death, but the lex talionis was applied. He must suffer the same injury that he had inflicted upon the appellor: an eye for an eye, a tooth for a tooth (citing Britton). However, $\mathrm{p} 48$ 'At a comparatively early date the lex talionis was abandoned and pecuniary compensation given...'. Also, pp 48-9 'As trespass accomplished the same purpose as the compensatory appeal, and at the same time gave the plaintiff the advantage of a less technical and dilatory procedure, and particularly the benefit of trial by jury, those appeals would naturally become more infrequent; and there were hardly any reported cases of appeal of wounding or imprisonment in the Year Books, and not many appeals of mayhem. The latest case that I found of appeal of mayhem is that of Hudson v Lee (1590), in which a plaintiff who had obtained damages in trespass sought unsuccessfully to recover additional damages in an appeal.'

${ }^{139}$ OW Holmes, The Common Law (Little Brown, 1945), pp 3-4 (he thought that appeals were extended to embrace harms that were foreseen, but not the intended consequence of the D's act, until much later on - citing a case in 1466, 6 Hen IV, pl 18, fo 7 (Case of Thorns (Hulle $v$ Orynge), Seipp No 1466.020)). See also, p 39 'appeals of the early law were directed only to intentional wrongs.' See also Bracton, n 10, vol 2 , p 384 (accidental homicide) and p 388 (intentional homicide, an appeal of).

${ }^{140}$ Bracton, $\mathrm{n} 10, \mathrm{vol}$ 2, p 409 'It may be said to be mayhem when one is rendered incapable of fighting, especially by him whom he is appealing, as where the bones protrude from his head or a large splinter of bone projects, as was said, [or] a bone is broken in some part of his body, or a foot or hand, or part of a foot or hand, or a finger or other member is cut off, or where sinews and limb are crippled by the wound dealt, or fingers have become crooked, or an eye has been gouged out, or some other thing done to the man's body whereby he is rendered less able and effective in defending himself...Castration, though it is hidden, is deemed mayhem. There are also other kinds of mayhem for which, as is evident, the duel will not remain, as where an ear or nose is cut off, for this will be disfigurement of the body rather than diminishment of strength.'

${ }^{141}$ See Appendix A. Bracton, n 10, vol 2, p 409 noted it was not mayhem where a person 'showed no wound to the coroners, or nothing except a scratch or a bruise [riffluram vel brusuram], contusions made by a club rather than an edged weapon.' As Ames, $n$ 109, noted, $p 48$, appeal of mayhem was trial by jury - not battle - since the appellor, being maimed, could not give battle. The punishment was the lex talionis - loss of limb for limb, unless the appellor would seek monetary compensation. See also $n 138$.

${ }^{142}$ Britton, n 11, p 103-4 (of appeals of mayhem).

${ }^{143}$ Ibid, p 103 'And our will is, that nothing be deemed a mayhem unless a member be lost, whereby a man is rendered less able to fight; as the loss of an eye, a hand, or a foot, or fracture of the skull bone, or loss of the fore teeth; but the loss of the molar teeth, or of an ear, or of the nose, is not accounted a mayhem, but a disfigurement only.'

${ }^{144}$ Ibid. 'Concerning mayhems, we are content that the maimed shall sue by appeals of felony against the offenders...'.
} 
suit may be brought civilly, as where one says, as though complaining of an injuria, and without adding words of felony, that such a one imprisoned such a one against the peace of the lord of that court etc... No corporal punishment then follows, only a pecuniary penalty by way of damages. ${ }^{145}$

Thus, by Bracton's time, the law seemed anxious that victims seek civil redress and damages, rather than criminal redress. ${ }^{146}$ One surmises this was likely to prevent the criminal courts from being 'clogged up' with minor batteries. ${ }^{147}$ (when did the right of victims to elect for civil redress, by way of an action for trespass, come about ? Ames thought that it came about c. 1252, commencing in the Curia Regis). ${ }^{148}$ Writing some 50 years after Bracton, in 1290, it was also Britton's recommendation that parties avail themselves of the civil remedy in the case of wounds less than mayhem since he stated:

Appeals of felony may also be brought for wounds but for avoiding the perilous risk of battle, it is better to proceed by our writs of trespass than by appeals ... ${ }^{149}$

\section{(e) Bracton - Aggravated Injury}

Bracton also considered injuria which were atrox. Clearly influenced by Roman law, he stated:

An injuria may be slight or grievous. In assessing damages, it is adjudged 'grievous' from the deed itself, as where one has been badly wounded, beaten and mistreated in breach of the peace. Or from the place where it was committed, in the king's court or a seigniorial court, before the justices or in the county court before the sheriff, in a theatre, at a fair, or in a market place, or elsewhere in the presence of many people. Or from the position of the wound, as where it is on the forehead or in the eye rather than in a hidden part. Or from the status of the person concerned, as where an injuria is done to magistrates or bailiffs, to parents or patrons. ${ }^{150}$

Thus, it seems that, by Bracton's time (c. 1240), the Anglo-Saxon tariff for wounds had dis-appeared, to be replaced by four main categories, viz.

- Mayhem - which comprised injuries that incapacitated a man from fighting;

- Grievous (atrox) injuries. This was likely the pre-cursor to our modern grievous bodily harm ('GBH');

- Less serious wounds, but ones still sufficiently serious for them to be dealt with by the royal courts. This was likely the pre-cursor to our actual bodily harm ('ABH');

- Minor wounds which the local courts (courts leet, sheriffs' courts) punished (if at all) but not the royal courts.

Much of the latter 'minor wounds' likely fell within Bracton's reference to 'trifling' wounds (see 7(b)) - for which he thought a person had a valid defence. Bracton also encouraged parties to seek damages for the above types of wounds - as opposed to criminal justice - not least, since the latter could be so harsh. Thus, one suspects

\footnotetext{
${ }^{145}$ Bracton, $\mathrm{n}$ 10, vol 2, p 411. Also, pp 437-8 'Now we must speak of the minor and less serious crimes which are sued civilly, as the personal actiones iniuriarum, which belong to the Crown since they are [sometimes] committed against the peace of the lord king. [Bracton then discussed serious crimes and continued] An injuria of this kind entails the ultimate penalty, when it is sued criminally. There is also another kind of injuria which is punished by nothing more than a pecuniary penalty, sometimes that and imprisonment, depending on the nature of the deed. An injuria is committed not only when a man is struck with a fist or flogged or beaten with clubs but when he has been insulted or victimized by defamatory verses and the like.'

${ }^{146} \mathrm{P} \& \mathrm{M}, \mathrm{n}$ 63, vol 2, p 489 'About the middle of the thirteenth century the growth of the action of trespass afforded the injured party an alternative and preferable mode of procedure. Saying nothing of felony, he would sue for damages, and Britton strongly advised him to do so [see text to $\mathrm{n}$ 149]. Thus once more instead of vengeance he could obtain, to use the old phrase, a sufficient bot, but a bot the amount of which was no longer fixed by law. The new procedure became so much more popular than the old that all 'offences against the person', except homicide, dropped out of the list of felonies.' Pollock and Maitland also noted that the 'justices had a certain discretion in deciding whether there was a wound sufficient to support an appeal.' See also vol 2, pp 526 et seq.

${ }^{147}$ Ames, $\mathrm{n} 109, \mathrm{p} 45$ 'The concession of trespass to parties injured was not so generous as first might appear. For in the first place plaintiffs had to buy the writ of trespass; and secondly, the unsuccessful defendant had to pay a fine for breaking the king's peace.'

${ }^{148}$ Ibid, p 44 'The pecuniary advantage to the plaintiff was not the only reason for their preference for trespass. By adopting this action they were relieved from the risk of trial by battle and from the extreme technicality of the procedure in general. Trespass was always tried in the Curia Regis by a jury.' Ames also noted that in Glanvill's time (c. 1189), appeals were determined only by battle whereas, in Bracton's time, the appellee had the option of battle or jury.

${ }_{149}$ Britton, n 11, p 104. Britton also thought that - even if an appeal was made and the alleged aggressor lost - the loser should be punished by way of imprisonment and making satisfaction as opposed to the more harsh criminal punishment. Britton also considered that punishments should be heavier where, for example, a ribald (a worthless fellow) struck a knight or other 'honorable' (i.e. important) person. Ibid. Cf. Coutumes de Beauvasis (1283), n 98 (prison term if a commoner strikes a man of substance (homme vaillant)).

${ }^{150}$ Bracton, $\mathrm{n} 10$, vol 2, p 439. A person could elect to go for a criminal, or a civil, remedy. However, once he went by way of a criminal appeal he could not change to a civil one. Ibid, p 396.
} 
that most wounds less than mayhem did not result in a criminal prosecution, in practice.

\section{(f) Britton (c. 1290) - Tournaments}

Britton (c. 1290) also mentioned that - in the case of wounds received in 'jousts, or such warlike feats' - no offence was committed. ${ }^{151}$ Where tournaments were expressly permitted by the Crown (to encourage military prowess) the situation was treated as equivalent to martial law (see also Appendix G).

\section{(g) Fleta (c. 1290)}

Finally, Fleta (another legal writer in the $13^{\text {th }}$ century) discussed mayhem ${ }^{152}$ as well as wounds and wounding. ${ }^{153}$ Like Bracton, Fleta dismissed any criminal prosecution of trivial wounds and blows, for which civil redress only should be available. ${ }^{154}$ Fleta also referred to a standard form of the appeal of wounding - one similar to that of Bracton. ${ }^{155}$

In conclusion, there was a sea-change in relation to the criminal law on wounding, probably around 1189. Gone was the tariff of wounds. Instead, wounding, basically, fell into 4 categories. Further, victims were generally encouraged to seek civil - as opposed to criminal - redress.

\section{Summary - Law Up to 1290}

In relation to the development of English law up to 1290 - in so far as it concerns assault and battery - the position would seem to be fairly clear.

- Anglo-Saxon (6th c - 1066). The pre-dominant forms of battery, in Anglo-Saxon times, embraced by the criminal law (which was scant in nature) comprised: homicide, rape and wounding (also, later, fighting as such). The punishment for wounding was a tariff system, which specified the type of wound and the monetary fine payable - wite, to the sovereign and/or compensation (bot), to the victim or his family. The level of fine (and/or compensation) often depended on the status of the victim as well as the location where the wound was received. Major blows and bruises were also punishable. Assault (i.e. a threatened battery) does not appear to have been a crime;

- Henry I (c.1113). Even by the time of the Laws of Henry I (c. 1113) the Anglo-Saxon tariff for wounds had changed little. However, by this time (if not earlier) it seemed that - along with the tariff - and people being fined generally for fighting (fightwite) there was a larger fine payable where blood was shed as a result (blodwite). However, it is unlikely that minor wounds (blows or bruises) were subject to the sanction of the criminal law. Nor assault (i.e. a threatened battery);

- Bracton-Fleta (c.1240-90). By the time of Bracton (c. 1240) the tariff had been replaced by a 4 fourfold classification of injuries: (a) mayhem (wounds which incapacitated a man from fighting); (b) grievous wounds (atrox injuria); (c) other wounds sufficiently serious for the royal courts to deal with (because they could be said to involve a 'breach of the king's peace'); and (d) trivial wounds, bruises and blows (these the king's courts did not take into account and - if a criminal offence at all - they

\footnotetext{
${ }^{151}$ Britton, $\mathrm{n} 11, \mathrm{p} 105$ 'We have said, in time of peace, because as to injuries done at tournaments and jousts, or such warlike feats, we will not interpose, unless the acts be done in our presence.' (the latter reference appears to exclude unauthorized fighting in the sovereign's presence or in his palace or courts, see also 40(a)). J Selden, England's Epinomis (1683), pp 30-1 maintained that tournaments (designed to demonstrate martial valour) were instituted by Stephen (1135-54), prohibited by Henry II (1154-89) and then re-instituted by Richard I (1189-99) by a charter to the Archbishop of Canterbury (Hubert Walter, archbishop 1193-1205) which Selden reproduced. See charter of 22 August 1194 also referred to in H Hall, The Red Book of the Exchequer (Eyre \& Spottiswoode, 1896), pt 1, p xcii. At tournaments a person could often sustain serious injury or death. See generally R Barber \& J Barker, Tournaments (Boydell Press, 1989) and Appendix G.

${ }^{152}$ Fleta, n 12, SS, vol 24, p 96 'It remains to consider criminal wrongs which do not entail death, such as mayhems, imprisonings and woundings. When anyone receives a hurt in any part of his body, whereby he is rendered incapable of fighting, it may be said to be mayhem, as, for example, if a hand or a foot is cut off, an eye is put out or the skull is fractured; or should a man lose his front teeth or be castrated, he may be adjudged to be maimed. The loss of molar teeth or of an ear should be called disfigurement rather than mayhem, because a man's strength is not on that account diminished...If he is convicted thereby, he may justly be condemned to lose member for member, unless he can [otherwise] satisfy the party, and further be committed to goal for breach of the king's peace.'

${ }^{153}$ Ibid, ch 39.

${ }^{154}$ Ibid. 'Further [he may pray judgment] of the triviality of the wound, as for example if it be no more than a scratch [ruflura], in which it should be called trespass rather than felony, or if it were done with a stick or stone, since weapons of this sort, though they make fearful blows, do not make wounds; and in these cases battle should not be joined.'

${ }^{155}$ Ibid, p 97. 'A appeals B [for that on a certain day, whereas he was in the king's peace in a certain place], the said B came with his force and against the king's peace, feloniously and in a premeditated assault [in assultu premeditato], attacked him and dealt him a certain wound in such a place in his body, of such length, width and depth, with a weapon of such a kind. And that he did this wickedly and feloniously, he offers to prove against him by his body as the court shall award.' See also n 126 (Bracton's version).
} 
would only have been subject to a fine by the local courts (courts leet, sheriff's courts etc.)). Assault as a crime had not yet emerged. This legal position was the same in 1290;

- Defences. The Laws of Henry I recognised self-defence as a defence to a charge of battery (wounding);

- No Criminal Redress. Bracton recognised the following as not being subject to criminal redress: (a) the trifling nature of the wound; (b) where punishment was lawfully administered by the requisite legal authorities (to prevent a breach of the peace or to punish it); (c) in a ' $j u s t$ ' war (where martial law would apply); (d) lawful correction (i.e. reasonable chastisement by a parent, schoolmaster, master of servants and apprentices etc.). Finally, tournaments and jousts conducted with the permission of the sovereign, were treated as akin to martial law.

In conclusion, by 1290, an elaborate tariff had been reduced to more manageable classification. There was also an emphasis on parties seeking civil redress (damages). As such, the law had become more civilised. ${ }^{156}$

\section{Yearbook Cases}

The Yearbooks contain cases for cases for the period $1268-1535 .{ }^{157}$ These include a number on assault and battery, ones often referred to in later legal texts.

- However, it is a pity there is no legal text dealing with battery after Fleta (c. 1290) until Lambard in $1581{ }^{158}$ since changes to the law on battery - as well as the recognition of the concept of 'assault' (i.e. a threatened battery only) - would then be more easily identified;

- That said, the Yearbook cases are useful ${ }^{159}$ and, in this period, assault and battery was treated both as a criminal, and a civil, offence - with the victim being able to elect. It is also important to note (as Putnam does) that - although many cases cited in the Yearbooks were civil ones - this did not diminish the ability of the victim to proceed by way of a criminal appeal. ${ }^{160}$ The desire of victims to seek a civil remedy accords with the emphasis placed by Bracton and Britton that they seek civil redress where possible (see 7). Also, one imagines that victims were (usually) more satisfied with damages rather than having the assailant receive a fine or being imprisoned, for what might be a relatively small sum or a short period.

- Yearbook cases from 1348 indicate that assault (i.e. a threatened battery) was recognised.

Yearbook cases often cited include the following:

\section{(a) Assault}

By 1348 (at least) assault was recognised as separate from battery. Cases often cited in respect of this comprise the following:

- Case in 1348. A case of trespass before the King's Bench. A would-be tavern customer struck out at an innkeeper's wife with a hatchet when she told him the tavern was closed. Although he did not hit her, damages were awarded; ${ }^{161}$

\footnotetext{
${ }^{156}$ I say this because (like Roman law) the English courts became more interested in punishing - by means of the criminal law - only woundings that were especially severe and (in the case of the royal courts) those which could be said to affect the king's peace (as opposed to private quarrels which did not affect the wider community). Further, the English courts moved away from a tariff system and towards a more flexible method of punishment - one which depended, to a greater extent, on the facts in the instant case.

${ }^{157}$ See $\mathrm{n} 14$.

${ }^{158}$ As will be seen, Lambard's Eirenarcha in 1581 deals with assault and battery in a short passage (see 10) and Lambard tended to be often cited by later legal writers.

${ }^{159}$ A wordsearch of the Seipp Index in respect of the words 'assault' and 'battery' also produces many interesting cases.

${ }^{160}$ BH Putnam, Proceedings before the Justices of the Peace in the Fourteenth and Fifteenth Centuries (1938), pp clvi-ii. 'the civil action of trespass and the indictable trespass share a joint prosperity. The growth of the writ is not, it would seem, at the expense of the indictment, and there is no encroachment of the one upon the other, no serious gap, and therefore no loss of ground by crime in favour of tort.' She also noted, $\mathrm{p}$ cliv 'In the sixteenth century lawyers found the useful word 'misdemeanour' which they applied to trespasses when made the subject of criminal proceedings, thus leaving the old word 'trespass' to mean exclusively the civil form of action begun by original writ instead of by indictment.' In order to bring writs of trespass before the king's justices they had to contain the words 'with force and arms' (vi et armis) and 'against the king's peace' (contra pacem regis), or if they concerned the infringement of royal franchises. However, by 1350, the 'vi et armis' restriction was being avoided. See JH Baker, An Introduction to English Legal History (4 ${ }^{\text {th }}$ ed, 2002), pp 60-2.

${ }^{161} 22$ Edw 3, Lib Ass, pl 60 fo 99a (1348), Seipp no 1348.268ass. Seipp commentary '(Latin begins) I. of S. and his wife M. complain of W. of S. that in the year etc. with force and arms at S., W. made an attack on M. and wounded her (Latin ends). W. pleaded not guilty. It was found by verdict of the jury (dEnquest) that W. came at night to the house of the said I., and wanted to have purchased his wine, but the door of the tavern was closed, and he struck upon the door with a hatchet that he had in his hand. The woman P put her head out (oustr') at a window and commanded him to leave (lesser), and he perceived her and struck with the hatchet, but he did not touch the woman. Therefore the jury
} 
- Case in 1366. A case of trespass for assault, battery and wounding. ${ }^{162}$ It was held that a person could be guilty of assault, yet be excused of battery;

- $\quad$ Case in 1368. A case of trespass for assault, wounding and battery. Damages were awarded for the assault although there was no battery; ${ }^{163}$

- $\quad$ Case in 1371. A writ of trespass before the King's Bench for assault and battery (and for goods carried off). The prisoner was held liable for assault but not battery.

As to this, Reeves, in his History of the English Law (1787) stated: ${ }^{165}$

Actions for a battery were usually laid with an assault also; insultum fecit, et ipsum verberavit, vulneravit, et male tractavit, etc. [he insulted him and beat him, wounded him and ill-treated him etc.]. In the $22^{\text {nd }}$ year, [1348] a jury found that the defendant struck at the plaintiff with a hatchet, but did not hit him; and they prayed the discretion of the court as to the law upon the point, when the damages were ordered to be taxed for the assault only, and the judgment against the defendant was, capiatur [the name of a writ issued to levy a fine due to the king].

Again, where a defendant was found guilty of the assault, but not guilty of the battery, the plaintiff recovered damages for the former, and was amerced for the latter. Thus assault began to be considered as a distinct and independent cause of action. ${ }^{166}$ (wording divided for ease of reference)

It may be noted that a 'verbal' assault (i.e. threatening someone) was also treated as a form of assault. Thus, in a case in $1353,{ }^{167}$ it was held that - to threaten a tax collector such that he fled without collecting the tax - was an

(l'Enquest) said that it seemed to them that there was no trespass, since he did no harm (mal). Thorp CJKB said that there was wrong (mal) and trespass, for which he should recover damages, since he made an assault on the woman, as was found, although he did not do other harm. Therefore he said to assess (taxes) his damages, and they assessed (taxer') the damages at half a mark. Thorp CJKB adjudged that they recover their damages, and that the other was taken. (Latin begins) And note this (Latin ends), that for an assault made, one recovered damages.'

${ }^{162} 40$ Edw 3 pl 19 fo 40a (1366). Seipp no 1366.101. Seipp commentary 'In a writ of trespass, the P counted that on a certain day and year in a certain place, the D had made assault on him, and had beaten and wounded him wrongfully. The other pleaded not guilty, and it was found by nisi prius that he had made assault on him on various days, but that he had not beaten him. Now the P prayed judgment on the verdict. The D's counsel said that it was found against the P, because it was found that he had not beaten him, but that he had made assault on him, which was not a matter against the peace, because one would not have this action for an assault without more. And also they had said that he had made assault on him on various days, and they had assessed (taxes) damages at 20 marks for all the assaults that he had made on him, where he had counted of a trespass committed on one day, so that he would not have an action for trespasses made on other days. The P asked the D's counsel where his client was, and because the D was not now in court, and it was found that he had made assault on him to the damages of 20 marks, it was awarded that the P recover his damages of 20 marks, and because it was found that he had not beaten him, the P was amerced.' See also 7 Edw 4, pl 31, fo 24a-b. Seipp no 1467.069)(trespass for breaking life and limb. By Choke and Nedham, a person will have an action on the case for threatened assault made to his person, although he was not beaten).

$16342 \mathrm{Edw} 3$, pl 25, fo 7a (1368). Seipp no 1368.025. Seipp commentary 'Trespass was brought against one, and he counted that he had made assault on him, and had wounded and beaten him etc. The D pleaded not guilty. The jury (l'enquest) came and said that he had made assault upon him, but he had not taken any damage, and he was not beaten or wounded, and they assessed (taxer') the damages at half a mark, and awarded that the P recover half a mark.' See also TA Street, The Theory and Principles of Tort Law (1906 ), p 11 which cites this case.

${ }^{164} 45$ Edw 3 pl 35 fo 24b-25a (1371). Seipp no 1371.058. Seipp commentary. 'In a writ of trespass brought in the king's bench for assault and battery and for goods carried off, the D pleaded not guilty. The inquest was taken at nisi prius before Wychyngham JCP, where it was found by verdict that he was not guilty of the battery and of carrying off the goods, and it was found that the D, on the same day that the P had assigned battery, had made assault on the P, and also on another day, to his damages of 20 pounds. Now on the day that they had in court (en banke), the P prayed judgment on the verdict. The D said that it was found by verdict that he was not guilty of the battery and also of carrying off the goods, and the assault that was found was not a trespass for which the party could be damaged, so that he understood that it was found for the D. The $\mathrm{P}$ said that one would recover damages by reason of assault, because he was disturbed from his affairs, so it was understood that he was damaged by this, so that it was right (reason) that he recover his damages assessed by the jury (l'enquest). The D said that the damages were assessed (taxes) at 20 pounds by the verdict, and he was excused of everything except of the assault, and they had said that on another day he had made assault, and they had assessed (taxer) the one assault and the other at 20 pounds, so that they had assessed (taxes) more than the P had counted, so that the P would not recover damages for something else than he had complained of. Fyncheden CJCP said that when he made assault on one day, as was supposed by the count, and also on another day he continued the first tort, thus in law the same assault, therefore the court awarded that he recover his damages assessed (taxes) at 20 pounds, and that the D be taken.'

165 J Reeves, History of the English Law (2 ${ }^{\text {nd }}$ ed, 1787, rep Rothmans, 1969). See also Street, n 163, p 7(he cites earlier Yearbook cases where self-defence was not a good justification for a battery).

166 Ibid, vol; 3, p 85. Reeves cited the cases of 1348 and 1366 (see above text).

16727 Edw 3, Lib Ass, pl 11 fo 134a (1353). Seipp no 1353.136ass. Seipp commentary 'A collector of the fifteenth of a vill sued for the king and for himself against certain persons, that at the time when he was collecting the king's money (deniers), he assaulted and beat him, and by force of this threat (menasse) drove him out of the vill. They pleaded not guilty. It was found that in performing his office they had rebuked him for (or with) bad words, so that by reason of this he did not dare to remain in the vill, but in right of battery not guilty. And because it was found that they had rebuked him, thereby he had made assault, and it was adjudged that he recover his damages, assessed by the jury (l'enquest) at 100 shillings. Query, if the king had not been party.' 
assault. In conclusion, the situation was summarised by Holdsworth:

As early as the fourteenth century it was held that trespass would lie for an attempted battery which had failed to take effect - for instance when one had thrown a hatchet at another which had missed; for a threatened battery if accompanied by actual damage; and even for threatening words which put the plaintiff in fear, and caused him damage. ${ }^{168}$

\section{(b) Defence - Self Defence \& Defence of Others}

The Laws of Henry I treated self-defence as a defence to battery. So did Bracton - as defences to homicide and hamsocn (and he, doubtless, would have included battery). ${ }^{169}$ Yearbook cases include the following:

- Case in 1369. A case of trespass before the Common Pleas for battery, self-defence was raised; ${ }^{170}$

- Case in 1388. A case of trespass for the battery of a man's wife. D pleaded that the husband and wife had assaulted him first; ${ }^{171}$

- $\quad$ Case in 1400. A case of trespass before the Common Pleas for battery. It was held that a victim, if he could escape, could not, lawfully, beat his assailant (i.e. self-defence must be proportionate). It may also be noted that, in this case, Cockayn (Sjt and later Chief Baron of the Exchequer) asserted that a person did not have to wait for the blow (this accords with the law in the time of Henry I (c.1113), see 5), ${ }^{172}$

- $\quad$ Case in 1410. A case of trespass for battery. Colepepper JCP observed that self-defence would be a justification; 173

- $\quad$ Case in 1440. A case of trespass for an assault against the wife of a man. Self-defence was asserted; ${ }^{174}$

- $\quad$ Case in 1455. A case of trespass for threats against life and member. If a person was assaulted and he could escape with his life, without being wounded or mayhemed, it was unlawful for him to beat (or wound) the person assaulting (see also the case in 1400 above). In effect, self-defence must be proportionate; ${ }^{175}$

\footnotetext{
${ }^{168}$ W Holdsworth, A History of English Law (Sweet \& Maxwell, 2009 rep), vol 8, p 422. Holdsworth cited the cases in 1348 (see n 161) and 1353 (see n 167). Holdsworth went on to state; 'It was the same emphasis on intention which has given us our modern definition of battery. In its original conception it meant the infliction of physical injury; and we have seen that in the Middle Ages an action lay whether it was committed intentionally, negligently, or accidentally.'

169 See ns 99 \& 132. JH Baker, Collected Papers on English Legal History (Cambridge UP, 2013), vol 2, ch 53, Some Early Newgate Reports 1315-1328, p 968 cited an early case where a person pleaded not guilty to murder in that, being struck by a stick wielded by the deceased, he had drawn a knife to ward off the blow. The deceased had then struck his arm against the knife, sustaining a fatal wound. The right to self defence can be found in Continental legal systems at this time. See eg. JM Powell, The Liber Augustalis or the Constitutions of Melfi promulgated by the Emperor Frederick II for the Kingdom of Sicily in 1231 (Syracuse University Press, 1971), p 18 which also asserts the legal justification for this: 'The authority of the law of nations has introduced that each man should be permitted to protect his own body, and natural reason does not find this abhorrent.' The Constitutions also noted that (like English law) the principle extended to the protection of family members and to property, movable and immovable. Ibid, $\mathrm{p} 19$.

${ }^{170} 43 \mathrm{Edw} 3 \mathrm{pl} 18$ fo 23b(1369). Seipp no 1369.072. Seipp commentary 'A man brought a writ of trespass for battery, and supposed by the writ that the $\mathrm{D}$ had beaten him in $\mathrm{D}$. The $\mathrm{D}$ said that, whereas the $\mathrm{P}$ had supposed that he had beaten the $\mathrm{P}$ in $\mathrm{D}$., he said that on the same day that the $\mathrm{P}$ had counted, the $\mathrm{P}$ had made assault on him in S., and the harm (male) that the $\mathrm{P}$ had was of his own assault, without this that the D had beaten him in D. in the manner that the writ supposed; judgment if tort etc.'

${ }^{171} 12$ Ric 2 pl 10, Ames 59 (1388). Seipp no 1388.077am. Seipp commentary 'Deiser: In trespass by the husband and wife for a battery to the wife, the D alleged that, the husband and wife had assaulted him, so that the injury to the wife was the result of her own wrong.' See GF Deiser, Year Books of Richard II: 12 Richard II (1388-1389) Ames Foundation, vol 59 (Cambridge, 1914).

1722 Hen 4 pl 41 fo 8a-b (1400). Seipp no 1400.041, Seipp commentary 'When one man assaults another, if he who is assaulted can escape with his life, the law does not permit him to beat his assailant. Quod tota curia concessit. Cockayn [Sjt] I am not held to wait for his blow.' For the latter cf. n 102 (Laws of Henry I). See also Fitzherbert, n 18 (title Barre) no 172 and Rolle, n 21, vol 2, p 547.

17311 Hen 4, pl 21, fo 65a-b, Seipp no 1410.059. Seipp commentary 'Colepepper JCP 'if one commits battery in self-defence, he could make justification on this matter.'

17419 Hen 6 pl 101, fo 47a (1440), Seipp no 1440.119. Seipp commentary 'Newton CJCP: if one assault me on Sunday, and I beat him in my defence, and for this trespass he brings a writ, and counts the trespass to have been committed on the Saturday before or the Monday after, or any other day, it is no traverse to say that I did not beat him on the day that he has counted, and if I say 'not guilty' generally, and the inquest (jury) appears and says that I beat him on another day than it really was, that was the assault of the P himself, such verdict amounts to 'guilty', and by such manner of pleading as before it will be aided, so it is better to plead thus, and not generally 'not guilty', for the mischief of the verdict.'

17533 Hen 6 pl 10 fo 18b (1455). Seipp no1455.037.This case was best summed up by Fitzherbert as contained in the Seipp commentary 'Fitzherbert Trespas 72, fol. 207v, dated Pasch. 33 Hen. 6, fol. 18: Note by Prysot CJCP that if one assault me by beating (me) (battery) I cannot lawfullly (per ley) threaten (manasse) his life and member unless it be to save my life, that is, in such a place where I cannot flee (fuere), etc., in (a case of) Trespass brought on threats (manasse) only.'
} 
- $\quad$ Case in 1457. A case of trespass for battery before the Common Pleas (for the beating of servants, loss of their service and the taking of goods and chattels). It was held by the court to be a defence that the servants were protecting their master since this was regarded the same as if the master were protecting himself (se defendendo); ${ }^{176}$

- Case in 1470. A case of trespass before the Common Pleas. A servant (on the orders of his master) assaulted one who was assaulting the D's son. This was held to be a good defence; ${ }^{177}$

- $\quad$ Case in 1472. A case of battery before the King's Bench. Self-defence was pleaded by a number of persons; ${ }^{178}$

- $\quad$ Case in 1477. A case of trespass for assault, battery and threats. Self-defence was pleaded; ${ }^{179}$

- $\quad$ Case in 1491. A case of trespass for assault, beating and wounding. Self-defence was pleaded. ${ }^{180}$

\section{(c) Defence - Protecting Land or Goods}

The courts also upheld the right of a person to defend his land and possessions which included his wife, villains and (by extension of villains) servants.

- $\quad$ Case in 1402 - Land. A case of trespass for assault, battery, wounding and imprisonment A man seized another by the neck to prevent him stopping the river at the former's mill; ${ }^{181}$

- Case in 1433 - Goods. A case of trespass before the Common Pleas. It was held a good defence for a man to act to protect his possessions (a booth at a fair in Cambridge); ${ }^{182}$

\footnotetext{
${ }^{176} 35$ Hen 6 pl 15 fo 50b-51a (1457). Seipp no 1457.015. Seipp commentary 'The other Ds pleaded that they were with another (not named in the writ) as his servants, and then P with his servants arrayed with armor came with bows and arrows, who there assaulted Ds' master and would have slain him, and that Ds in defence of their master beat P and his servants, so it was their (P's and his servants') own assault, and as to the goods, the other Ds pleaded that the took the armor, bows and arrows for their safety, and kept them until their (P's and his servants') malice had diminished and passed, and then redelivered the goods back.'

1779 Edw 4 pl 4 fo 48b (1470). Seipp no 1470.004. Seipp commentary.'D master sued for assault committed by D's servant at D's command. Sjt Catesby (for P): where one makes an assault on me, if I beat him in my defence I will be excused, but if he makes an assault on a stranger I cannot beat him in defence of him (the stranger), because I have nothing to do with him, but I can separate (departer) them, etc. Moyle JCP and Nedeham JCP: if I see one committing an assault on another, I can separate (departer) them, and put my hand on he who made the assault, and hold him so that he does not come to the other (victim of his assault), etc. but they (Moyle JCP and Nedeham JCP) said that I cannot draw my sword (traher mon espe) and beat he who made the assault, etc., but it is otherwise if one make an assault on my master, I can beat him, in defence of my master, etc. Choke JCP: this is true, because the servant is held (tenus) and bound (lie) to the master, and so he can (beat another) for (in defence of) his mistress (Mastresse), etc.; but the master cannot do so for (in defence of) his servant, because he (master) is not bound (tenus) to do for his servant, etc.'
}

${ }^{178} 12$ Edw 4 pl 15 fo 6a.(1472). Seipp no 1472.023. Seipp commentary. 'Ds pleaded that P had assaulted Ds, that Ds had defended themselves, and that the wrong (tort) done to P was of P's own assault and in Ds' defence (self-defence). The Justices held Ds' plea good because each D could defend the other against a joint assault.' Noted by Brooke, n 19 (title Trespass), no 37.

${ }^{179} 16 \mathrm{Edw} 4 \mathrm{pl} 8$ fo $11 \mathrm{a}-\mathrm{b}$ (1477). Seipp no 1477.008. Seipp commentary ' D pleaded as to the coming with force and threatening (?), not guilty, and as to the rest of the trespass D pleaded that $\mathrm{P}$ on the same day and at the same time had made an assault on $\mathrm{D}$, that $\mathrm{D}$ asked $\mathrm{P}$ to suffer $\mathrm{D}$ to be in peace, and $\mathrm{P}$ would not, D said that he would defend himself, and sooner than D would suffer himself to be beaten, D would beat $\mathrm{P}$, that $\mathrm{P}$ would not cease (surcesser) from P's assault, so D in his own defence beat P, which was the same assault and threatening of which P had conceived his action, which matter D wanted to aver. The Court said that D's plea amounted to no more than that the damage that P had was P's own assault (de son assaut demesne), and in D's defence, so all the rest (of D's plea) was void. D said that this was not so in this case, but D's plea was good, because P had counted and complained of being aggrieved by D's threatening, for which P intended to recover damages, so D necessarily ought to answer to this, or otherwise such an answer would be denied to D. The Court agreed to this.'

${ }^{180} 6$ Hen 7 pl 2 fo 41b (1491). Seipp no 1491.012.Seipp commentary. 'One D justified wounding (navrer) and the wounds (les plages) by assault by the $\mathrm{P}$ himself, and the ill (mal) that $\mathrm{P}$ had was his own assault, and in the first D's self-defence. P replied that (the trespass was) of the first D's own wrong denying (sans) such cause. The parties were at issue.' The other two Ds pleaded 'not guilty'. The jury appeared. It was said by award of the Court that if the plea of the first $\mathrm{D}$ who justified was found against the first $\mathrm{D}$, then the first $\mathrm{D}$ would be charged for the entire damages, and the jury would not inquire whether or not the Ds wounded (navrerent) P, because this was confessed by the (first D's) justification, but as to the other two Ds, the jury would inquire what (combien) they did, because they could make asault and not wound (navrer) P, and so if it were so, the damages against all (three) Ds in common for the assault, and for the wounding (navrer) and the rest, against the first D who justified.'

${ }^{181} 3$ Hen 4 pl 3 fo 8b-9a (1402). Seipp no 1402.003. Seipp commentary. 'D pleaded not guilty to assault and taking fine, and as to battery P stopped the river at D's mill and D held him by the neck. As to imprisonment, D justified as aiding the constable in arresting P to find surety for the peace. P pleaded the constable had no power to make men find surety. P did not dare to demur. Issue joined on D's plea 'P's own fault' (de son tort demesne sans tiel cause).' See also Rolle, n 21, vol 2, p 547, line 11.

${ }^{182} 11$ Hen 6 pl 20 fo 23a (1433). Seipp no 1433.020. Seipp Commentary. D pleaded the mayor and bailiffs assigned him a place for his booth at the fair, and as he was building his booth, P came and would have broken up D's booth, but D took P by the arm in a peaceable manner, and asked him not to break up D's booth. P replied that the place that D claimed to be assigned to him was the freehold of a prior who assigned it to 
- Case in 1440 - Goods. A case of trespass for assault, wounding and maltreatment. The court accepted that it was a defence to protect one's goods (including a wife); ${ }^{183}$

- Case in 1469 - Goods. A case of trespass for battery before the Common Pleas. The court held that it was not a battery to prevent a person taking (stealing) one's goods; ${ }^{184}$

- Case in 1470 - Land. A man might beat another in defence of his freehold, farm or highway.

\section{(d) Lawful Correction - Servant, Pupil, Apprentice, Madman}

Although the courts held (in 1460) that a servant could not be physically compelled to return to his service, ${ }^{186}$ a servant (or apprentice) could be beaten for negligence. Wives could also be corrected. And madmen beaten, in order to restrain them.

- Case in 1348. A bill of trespass for beating, wounding, maiming and imprisonment. It was pleaded in defence that $\mathrm{P}$ was a madman and he was restrained to prevent him harming others; ${ }^{187}$

- Case in 1481. A case for trespass for assault, battery and false imprisonment. A London apprentice (aged 14) was beaten by his master for being (it was asserted) negligent in his (hosiery) trade. The case does not indicate an outcome. However, this case was later taken as authority for the lawful correction of an apprentice by Pulton (see 12) and others; ${ }^{188}$

- Case in 1481. A case of trespass for battery. It related to correction of an apprentice. The issue of beating a servant twice over for the same offence was canvassed; ${ }^{189}$

- $\quad$ Case in 1483. A case of false imprisonment before the King's Bench. A man imprisoned (for an hour) another man (a Scot) on the basis that he might be a traitor. ${ }^{190}$ Meeting the Scotsman's wife on a

$\mathrm{P}$, and D came to P and beat him with swords and staffs and wounded him. Paston JCP said that the freehold was irrelevant. P replied that even if P came and broke up D's booth, D could not beat P. Paston JCP said that D's plea was good. See also Rolle, n 21, p 547, line 115.

18319 Hen 6 pl 59, fo 31a-b (1440). Seipp no 1440.077. Seipp commentary 'Interesting case, in which D justifies assaulting P as defence of D's chattels, and P argued that because D had a remedy at common law in trespass for P's taking of D's goods, D should not be justified in resorting to self-help; and Paston JCP argued that one would want to beat a person who wanted to take his wife, and that this would be in defence of one's chattel (meaning that a wife was a chattel, or perhaps meaning that the wife would be taken with her clothes which were chattels of D husband) justification of defence of goods pleaded, defence of servant.' See also Rolle, n 21, vol 2, p 546, line 52. See also Street, n 163 , p 8.

${ }^{184} 9$ Edw 4 fo 28b, pl 42 (1469). Seipp no 1469.085. Seipp commentary: 'D pleaded that $P$ would have taken D's 5 pence, that $P$ put his hand on $\mathrm{D}$ (? or D put his hand on $\mathrm{P}$ ), and that $\mathrm{D}$ (? or P) did not suffer him (to do so). It was held by the Justices that one could put hands on another to prevent him from taking one's goods, and could beat the taker sooner than letting him carry those goods off.'

${ }^{185} 10 \mathrm{Edw} 4$ fo 6b, pl 15 (1470). Seipp no 1470.033ss, Archbishop of Canterbury v Chapman \& Others, see SS, vol 47, p 58 (self defence in the case of assault when defending intrusion onto his alleged land). See also SS, vol 48, pp 58-9 (trespass for trampling grass, assault and affray to servants or tenants and threats to life and member, and breaking close).

${ }^{186} 38$ Hen 6 pl 2 fo 25a-b (1460). Seipp no 1460.010. Seipp commentary: Markham JCP: if my servant departs out of my service, I am not allowed (il ne list a moy) to take him against his will, but it is lawful for me to require (perhaps trans. request) that he return in my (son) service.'

18722 Edw 3 Lib Ass 56 fo 98a (1348). Seipp no 1348.264ass. See also Rolle, n 21, vol 5, p 546, line 26. Also, JH Baker \& SFC Milsom, Sources of English Legal History (1986), pp 311-2, 'Fyncheden [Sjt]. As to the battery and imprisonment, we tell you that at the time the P was in a mad fit and doing great harm; and for this reason the D and [the P's] other relations took him and tied him up and put him in a house and chastised him and beat him with a rod, without this that we imprisoned or beat him in any other manner; and we do not think that for such imprisonment and battery he can assign wrong in our person.' See also Street, $\mathrm{n} 163, \mathrm{p} 9$ and a case cited by Glanvill J in Beale v Carter (1588) Owen 98 (714 ER 927) where he referred to a case in 1568 (a constable locked up a madman who later died. It was held that the action of the constable was justifiable). Madmen were generally under the care of their relatives, see Downer, n 8, p 245, citing from the Laws of Henry I (c. 1113) 'Their relatives should compassionately care for insane persons and dangerous people of this kind.'

${ }^{188} 21 \mathrm{Edw} 4 \mathrm{pl} 17$ fo 6(a) (1481). Seipp no 1481.025. Cf. the commentary of Littleton JCP who appeared to argue that the matter would be governed by the deed of indenture in this case. Seipp commentary: 'Littleton JCP: this is no plea, because it is not lawful for one to beat his apprentice, even if he does not perform nor attend to his art (work), because you (D) can have a writ of covenant against him (P) query whether a schoolmaster can justify, because there is no prejudice to him (the schoolmaster) if the scholar (student) does not want to take learning (ne veut my prendre erudition), etc.' As to a schoolmaster and Bracton's words, see n 136. For a later case relating to the immoderate beating of an apprentice, see $R v$ Keller (1683) 2 Shower 289 (89 ER 945).

18921 Edw 4 pl 17 fo 53a. (1481). Seipp no 1481.085. Seipp commentary 'beating apprentices.(the reporter:) I was not present, but others said so to me. Spelman: it appears here that the D beat the P in another vill outside of L. (county), and I understand that one cannot beat his apprentice in any other vill except where he $(\mathrm{P})$ is made apprentice, and also he (D master) cannot beat him (P apprentice) twice for one same cause (odd application of double jeopardy principle?). Fairfax JKB: this is not so, because if he goes to the fair at Cambridge to sell his merchandise, and he commands his apprentice to sell his (chaffer-), and he (apprentice) refuses, it is not lawful for him (master) to beat (the apprentice)?, I say that it is; and as to the other case of beating him (apprentice) twice for one cause it is lawful, because if he said to the apprentice you have deserved 6 stripes for this fault (default) and you have 2 this day and 2 tomorrow, etc., some say then he (apprentice) will be beaten forever (infinite) which is unreasonable (n' est reason).'

19022 Edw 4, pl 9 fo 45(a)(1483). Seipp no 1483.009. 
highway he informed her of this and she went wild. So, he imprisoned her (for an hour) as well. The court did not dispute, in this case, the right of a person to restrain a madmen on the basis that he might otherwise cause injury to himself or to others (i.e. a breach of the peace). ${ }^{191}$

In conclusion, it is unsurprising that personal correction was available in these cases since it was a corollary of the head of the household being responsible for his family, servants and slaves - and that this had long been the position under English (as well as Roman) law. ${ }^{192}$

\section{(e) Defence - Legal Justification}

Restraint or chastisement lawfully inflicted pursuant to due legal process was upheld, since it was to prevent a breach of the peace or to punish it.

- $\quad$ Case in 1477. A case of trespass before the Common Pleas, for assault, battery and imprisonment. Legal justification was pleaded, that of helping a constable arrest a suspected robber; ${ }^{193}$

- $\quad$ Case in 1489. A case of trespass for assault, wounding and imprisonment. A village constable pleaded that he had arrested $\mathrm{P}$ and taken him to jail for breach of the peace. This was held to be a good plea (justification); ${ }^{194}$

- Case in 1505. A case of trespass before the King's Bench, for assault, battery and wounding. Legal justification was pleaded (the making of an arrest pursuant to a warrant). ${ }^{195}$

\section{(f) Duels}

Tournaments (unless authorised by the sovereign, for encouraging martial prowess) were unlawful as a breach of the peace. This is unsurprising since the intent behind many tournaments (and jousts) as well as duels was to kill or severely injure the other person.

- $\quad$ Case in 1496. This case appears to be one of felony by misadventure. Fineux CJ indicated that it was a felony where two people agreed to a duel and one killed the other. ${ }^{196}$ And (although Fineux CJ did not expressly say so) the same logic also applies in respect of battery.

\footnotetext{
19122 Edw 4 pl 10 fo 45a-b (1483). Seipp no 1483.010. Seipp commentary 'D pleaded that D, on the day and year the other imprisonment was supposed (in the previous plea [see n 190) met (obvia) this same P's wife in the highway and D told (narra) and gave notice of all the matter (in the previous plea), that $\mathrm{P}$ was taken in prison as a Scot, that P's wife behaved in such a way that it seemed that P's wife was wild like one who was a lunatic, that $\mathrm{D}$ to avoid the graver mischief that could ensue to P's wife, took P's wife and put her in his house for the space (time) of one hour. Fairfax JKB said that this was no plea, and told D that D should have surmised in fact that P's wife was wild (fere, insane), and should have supposed that P's wife would have slain herself or done other mischief, and that D was in fear (en drede) that P's wife would have done some mischief, so D took P's wife and put her in D's house.'

192 See also ns 214-8. Holmes, n 139, pp 19-20 'To return to the English, the later laws, from about a hundred years after Alfred [king from 871-99] down to the collection known as the laws of Henry I [c.1113], compiled long after the Conquest, increase the lord's liability for his household, and make his surety for his men's good conduct.'

${ }^{193} 17 \mathrm{Edw} 4 \mathrm{pl}$ 1, fo 5a-5b (1477). Seipp no 1477.022. Seipp commentary 'D pleaded that one was robbed by two robbers on such a day, that the robbers came to the P's house, that the constable of the same vill, because the constable had suspected P of the same felony, arrested P, that inasmuch as $\mathrm{P}$ would not obey his arrest, the constable of the vill commanded D to assist him, that D put his hands on $\mathrm{P}$, which was the same battery, that $\mathrm{D}$ went with the constable in aid of him, and that $\mathrm{D}$ delivered $\mathrm{P}$ to the gaoler, which was the same imprisonment of which $\mathrm{P}$ brought his writ. $\mathrm{P}$ replied that $\mathrm{P}$ had complained that $\mathrm{D}$ had imprisoned $\mathrm{P}$, and that $\mathrm{D}$ had shown the imprisonment to have been done by another, that is to say, the gaoler, which was no answer to P.' The court held (teignont) the plee good enough notwithstanding this.' See also Brooke, n 19 (title Trespass), no 335 .

${ }^{194} 5$ Hen 7 pl 12 fo 6a-6b (1489). Seipp no 1489.043. Seipp commentary 'P counted that D on such a day and year with force and arms had assaulted P, and wounded (navre) and imprisoned P for the space of one day. D justified the wounding, because P made assault on D himself the same day and year in the same place, and the wrong that P had was P's own assault and in D's defence, and as to imprisonment D pleaded that $\mathrm{D}$ was constable in the same vill, and because $\mathrm{P}$ made assault on $\mathrm{D}$, and breached the peace, $\mathrm{D}$ took $\mathrm{P}$ and brought $\mathrm{P}$ to the gaol for conservation of the peace. This was held a good plea by all the Court. P replied that D's assault was of D's own wrong, denying such cause (de son tort demesne). This was held a good reply, because no matter of record was alleged in D's plea.'

${ }^{195} 21$ Hen $7 \mathrm{pl} 51$ fo 39a (1505). Seipp no 1505.051. Seipp commentary 'D pleaded that at the same day and place D had a warrant to arrest P, so at the same time and place D put his hands on P peaceably and arrested P, which was the same assault, battery, and wounding (of which P complains). Fyneux CJKB said that this was no plea, because this was neither assault, battery, nor wounding, but that D could have pleaded that P assaulted D and the injury to P was P's own assault.'

${ }^{196} 11$ Hen 7 pl 14 fo 23a (1496.029). Seipp commentary: 'Fyneux CJKB: if two play (ludunt) together with sword and buckler (= shield), or they joust (justent) together by their common assent, if the one kills (occist) the other, it will be called felony, because even though these games (ludes) are allowable (soufferables) by law, yet it is not lawful to use them except by the king's command when he (the king) commands them to joust, or to play (luser, should be luder?) with swords and bucklers before him (before the king)...it is otherwise if it be by the king's command, as in joustings (Justings), or suchlike distinction between accident and felony also mentioned in $1498.005=$ Hil. 13 Hen. 7, pl. 5, fol. 14a-14b (mayhem).' See also Brooke, n 19, (title Coron), no 229. Cf. Downer, n 8, p 271 (Laws of Henry I, c.1113), 'If a person in the course of a game of archery or of some exercise kills anyone with a spear or as a result of some accident of this kind, he shall pay [civil] compensation for
} 
Baker refers to an early $14^{\text {th }}$ century case (perhaps c 1330) in which, in a ball game (possibly, pelot (handball), a man gave another a blow. Even though he had struck the other against the peace, Scrope CJ awarded that he be discharged ('qil alast quit'). It seems likely that he was discharged on the basis that the blow was minor and, thus, not subject to the cognisance of the criminal courts. ${ }^{197}$ It is dubious whether any 'defence' had developed at this stage on the basis that a person had 'consented' to any intentional injury in the criminal context (where a person was accidentally, or negligently, injured the criminal law would not have applied in any case).

In conclusion, the Yearbook cases evidence that assault and battery could result in a criminal appeal or a civil penalty - at the victim's election. Further, self-defence as well as lawful correction and legal justification were recognised by the courts as 'defences' (justifications) to assault and battery - providing they were proportionate (reasonable).

\section{Lambard (1581)}

Since it was the duty of Justices of the Peace ('JP's') - as well as constables - to keep the peace, it is not surprising that the law of assault and battery was considered in texts relating to the same. This did not occur in the earliest texts. ${ }^{198}$ Thus, The Boke of Justices of Peas (1506) ${ }^{199}$ did not analyse the law on assault and battery. Nor did The Boke for a Justice of Peace (1534). ${ }^{200}$ However, Fitzherbert, in The Newe Boke of Justice of the Peas (1538), ${ }^{201}$ noted the right of a constable to exercise self-defence, in the case of an action for battery brought against him. ${ }^{202}$

\section{(a) Lambard-Definitions}

It was to Lambard, Eirenarcha (or the Office of the Justice of Peace)(1581), that many later legal texts dealing with assault and battery made reference. Lambard stated:

An assault, as it is fetched from an other fountain [i.e. from another legal system], namely from the latin assultus, which denoteth a leaping (or flying) upon a man: so that it can not be performed, without the offer of some hurtful blow, or at the least some fearful speech ${ }^{203} \ldots$

And to strike at a man (although he were neither hurt, nor hit, with the blow) was adjudged an assault, 22 lib assis pl 60 [case in 1348]. ${ }^{204}$ For this assault does not always necessarily imply a hitting: and therefore, in trespass of assault and battery, a man may be found guilty of the assault, and yet be excused of the battery: $40 \mathrm{Ed} 3.40$ and $45 \mathrm{Ed} 3.24$ [cases in 1366 and 1371] ${ }^{205}$ (spelling modernised).

Lambard went on mention cases where - although there had been an assault or battery - no breach of the peace was committed. ${ }^{206}$ These instances are now considered.

\section{(b) Lambard - Self Defence \& Defence of Others}

Lambard referred to self-defence and the defence of certain others. He stated:

\footnotetext{
him.' For duelling and the suppression of it (especially in the time of James I (1603-25), see Holdsworth, n 168, vol 5, pp 199-200 and Stephen, $\mathrm{n} 42$ (History), vol 3, pp 99-102. If either (or both) people in a duel were wounded either (or both) were guilty of affray and of assault and battery. See also Holdsworth, n 168, vol 5, p 200 citing Yearbook cases.

${ }^{197}$ Baker, n 169, p 976. See also JH Baker, The Reports of Sir John Spelman, SS, vol 94, pp 312-4(sword play). Tournaments seem to have been banned again in 1495, see Winn LJ in Lane v Holloway [1968] 1 QB 379, 394.

198 The exception is the reading of Thomas Marow in 1503, see $\mathrm{n} 207$.

199 The Boke of Justices of Peas (1506)(rep Professional Books, 1972).

${ }^{200}$ The Boke for a Justice of Peace (London, Thomas Berthel, 1534).

${ }^{201}$ See $\mathrm{n} 27$.

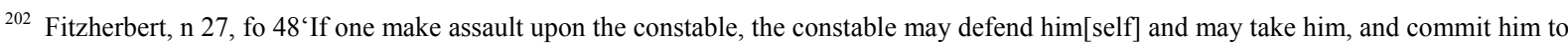
the jail until he have found surety to keep the peace, though that the assault were made upon himself. As it appears M 5 Hen 7 [a reference to a case in 1489, see Seipp no 1489.043, n 194] in the title Barre [see Fitzherbert, n 18, title Barre, no 141] much more then if a constable see one making assault upon a strange person, may he take him, and commit him to prison, or to the jail, until he has found surety to keep the peace.' (spelling modernised). See also Crompton, n 27 (published in 1584), p 173.

${ }^{203}$ Lambard, n 28, p 135. As to speech, Lambard continued 'And therefore, to rebuke a collector with foul words, so that he departed for fear without doing his office, was taken for an assault, 27 lib assis plac 11.' (spelling modernised) This refers to a case in 1353 (see n 167).

${ }^{204}$ See the case in Seipp no 1348.268ass, see n 161.

${ }^{205}$ See cases in Seipp no 1366.101, n 162 and 1371.058, n 164.

${ }^{206}$ Since no breach of the peace (i.e. no crime) was committed this should be reflected in legislation, as opposed to it being a 'defence'. The problem is that the words ' $j u s t i f i a b l e$ ' and 'defence' were commonly used by legal writers (and still are). However, it needs to be clear that, if a person, for example, lawfully arrests another he is not committing a battery (as opposed to his committing a battery but having a 'defence' (i.e. an excuse) for being punished for the same). See also 39.
} 
if a man be inforced [i.e. forced] to repulse violence (done unto his own person, or to the person of his wife, mother, child, kinsman, master, servant, or to his goods being in his possession) either by threatening or striking again: his so doing is also justifiable, as may be seen in Marr, ${ }^{207} 33 \mathrm{H} 618$ [case in 1455], ${ }^{208} 19 \mathrm{H} 631$ [case in 1440], ${ }^{209} 9 \mathrm{E} 448$ [case in 1470] ${ }^{210} \& 35$ Hen 650 [case in 1457]. ${ }^{211}$

However, Lambard noted that a fermor (or tenant) could not justify such an act in defence of his landlord. Nor a commoner in defence of the mayor (or bailiffs) of a corporate town. ${ }^{212}$

\section{(c) Lambard - Defence: Land \& Goods}

With respect to goods, in (b) above, reference was made by Lambard to 'his goods being in his possession.' Thus, he accepted that it was a defence to a charge of assault or battery, for a person to assert that they were defending their land or goods.

\section{(d) Lambard - Lawful Correction}

Lawful chastisement could also be asserted as a defence to assault or battery:

- Lambard noted that there was lawful chastisement in the following cases - providing that it was in moderation (i.e. reasonable): (a) a parent chastising his child; (b) a husband his wife; ${ }^{213}$ (c) a master his servant; (d) a schoolmaster his pupil; (e) a jailer his 'unruly prisoners'; (f) a lord his villain;

- These defences reflected - to a considerable extent - the position under Roman law where a father had potestas (authority) over his children and his wife, ${ }^{214}$ a master had authority over his slaves and servants, ${ }^{215}$ a tutor had authority over his pupil ${ }^{216}$ and a curator had authority over a mentally ill person. ${ }^{217}$ In other words, early English law (like Roman law) treated a man's wife, children, wards, villains and servants as equivalent to his possessions - not least since he was responsible for them; ${ }^{218}$

- These categories are also to be found in a reading (that is, a series of lectures) given by Thomas Marow in 1503 - which reading Lambard cited in his text of 1581. ${ }^{219}$ Because Marow's reading was never translated from its law French, it was Lambard was quoted to a much greater extent by subsequent legal writers.

\footnotetext{
${ }^{207}$ The reference is to T Marow, whose Reading on the Peace (a series of lectures in the Inner Temple) in 1503 (written in law French) is contained in BH Putnam, Early Treatises on the Practice of the Justices of Peace in the Fifteenth and Sixteenth Centuries (1924), p 332 et seq. See also JH Baker, Readers and Readings in the Inns of Court and Chancery (Selden Society, 2000). Marow (c. 1460-1505) is spelt a number of ways (including Marowe and Marrow). See generally, Oxford Dictionary of National Biography (Thomas Marow).

${ }^{208}$ See Seipp no 1455.037, see n 175.

${ }^{209}$ See Seipp.no 1440.119, see n 174.

${ }^{210}$ See Seipp no 1470.004, see n 177.

${ }^{211}$ See Seipp no 1457.015, see n 176. See also Harecourt v Spycer (1520), SS, vol 119 (Yearbooks of Henry VII), p 7 per Elyot J 'With respect to a man's person, it is not lawful for anyone to touch it forcibly unless he is in such great danger that he will perish without help: in that case one may beat a man to save the life of another, and it is justifiable. Thus, a servant may justify the battery in saving the life or limb of his master. So may a husband for his wife. These things are when someone is in danger; but otherwise one may not intermeddle with the person. With goods, however, it is [never] lawful for anyone to intermeddle. It is not lawful for someone to enter my land without my leave, even if his presence benefits me it may not suit my pleasure. Thus, driving beasts out of my corn, without my leave to enter the land, is wrong.' The latter cites Cuny v Brugewode (1506) Caryll's Reports, SS, vol 116, p 542.

${ }^{212}$ Lambard, n 28, p 139.

${ }^{213}$ Baker, $\mathrm{n}$ 169, vol 2, p 968, refers to a case before Bereford CJ (CJ of the Common Pleas, 1309-26) of an 80 year old man who killed his wife against his will while chastising her ('auxi cum il la voleyt aver chastice').

${ }^{214}$ Sandars, $\mathrm{n} 51$, $\mathrm{p}$ xxxvliii 'The paterfamilias, the head of the family, was said to have all the other members of his family in his power; and this power (patria potestas) was the foundation of all that peculiarly characterised the Roman family. At the head of the family stood the paterfamilias alone. Beneath him came his children, sons and daughters, and his wife, who, in order to preserve the symmetry of the system, was treated by law as a daughter. If a daughter married, she left his family, and passed into the family of her husband, but if a son married, all his children were as much in the power of the paterfamilias as the son himself. Thus all the descendants through the male line were in the power of the same person.'

${ }^{215}$ The power of a Roman citizen over his slave was, formerly, unlimited, but later became subject to restrictions. See Sandars, n 51 , p 511 .

${ }^{216}$ Sandars, $\mathrm{n} 51$, pp xl-xl1 'the Roman notion of a tutor... was a person who supplied something that was wanting, who filled up the measure of his pupil's persona. He of course took care of the person and property of the child; but this was only an accessory of his position; his primary office was to supply by his auctoritas what the pupil fell short of.' See also, pp 513-7.

${ }^{217} \mathrm{Ibid}, \mathrm{p}$ xli 'Curators were appointed to watch over the interests of insane persons, and of persons notoriously prodigal, as well as of those who had attained the age of puberty, but were under the age of twenty-five.' See also pp 517-8.

${ }^{218}$ See also Holmes, n 192.

${ }^{219}$ See n 207 (text of Marow).
} 
Thus, Lambard stated as to lawful correction:

But concerning the menacing, assault or battery of the person of one, this is to be noted by the way, that it is not in all cases a violation and breach of the peace: for some are allowed to have privately, a natural and some a civil power (or authority) over others, so that they may excuse themselves if but (in reasonable manner) they correct and chastise them for their offences, without imputation of any such breach.

After the one sort, the parent is suffered (with moderation) to threaten and chastise the child within age. By reason of the other sort of power, the husband is not punishable (so that it be not outrageously) if he chastise his wife, ${ }^{220}$ the master his servant, the schoolmaster his scholars, and a gaoler (or his servant, by his commandment) his unruly prisoners and the lord may beat his villain. But these things must nevertheless be done in convenient place, and therefore not in the presence of the prince, as it is thought 27 lib ass pl 49 [case in 1353]. ${ }^{221}$

The power of the master and schoolmaster, over the servant, and scholar, is affirmed by M[r] Marrow and confirmed by some opinion in the book $21 \mathrm{E} 46$ and 53 [cases in 1481]. ${ }^{222}$ Whereunto I may also add the mind of those that made the statute ( $33 \mathrm{H} 8$ cap 12) concerning malicious striking in the king's house: for they do therein specially exempt the master that strikes his servant, with his hand, fist, small staff, or stick, for his correction for any offence. ${ }^{223}$

Howbeit in these cases, I do advise both husband and master not to provide so much how they may escape the breach of a recognizance or punishment of our laws, as to forsee that they keep the law of God, and do nothing against honesty: the one as knowing that the wife is his own flesh and the other as considering that he also has a master in heaven. Every man may take also his kinsman that is mad, and put him in a house, and bind and beat him with rods, without breach of the peace. 22 lib ass plac 56 [case in 1348]. ${ }^{224}$

\section{(e) Lambard - Legal Justification}

\section{Lambard stated:}

A constable or other officer, or any other, being of their company, that shall be driven to strike any person, for the better executing of their office or charge (as in many cases they may lawfully do) breaks not the peace nor shall be in any peril of forfeiting any recognizance of the peace, by reason of any such assault or battery, as may be well inferred upon the book cases 17 E 45 [case in 1477]: ${ }^{225} 2$ E 46 \& 8 :

\footnotetext{
${ }^{220}$ Lambard, n 28, p 137. The text also stated: 'This power of the husband over the wife, seems to be permitted by the words of the supplicavit that is set down for her in the Register 89 [see S Theloall, Registrum Brevium (1687), 89] when she standeth in need of the peace against him, where it is said, that he shall be bound to do her no corporal harm, but with this exception 'aliter quam ad virum ex causa regiminis et castigationis uxoris suae licite et rationabiliter pertinent': [other than what is reasonably necessary to the discipline and correction of the wife] wherein it agrees with the civil law, which yields to the husband that power, so that he may use it modice, moderately. And sayeth M Peter Martyr upon the 1 to the Corinthians c 2 v 3. The husband may corrigere et castigare uxorem eadem charitate qua Christus ecclesiam verberat, nimiru, ut melior fiat etc. ' [chastise and punish his wife out of the same love with which Christ beats his church, surely, in order that it may become better.'] (spelling modernised). Peter Martyr (1457-1526) was an Italian born Spanish historian who also wrote on religious matters. See also Fitzherbert, The New Natura Brevium (6 $6^{\text {th }}$ ed, 1718), 80 (writ de securitate pacis) 'This writ lieth when a man is in fear or doubt that another will beat or assault him, and lieth properly where one man doth threaten another to kill him, beat him, or assault him.' See p 179F (if a husband threaten his wife to beat, or to kill her, she shall have this writ). See also Blackstone, $\mathrm{n} 36$, vol 4, pp 250-1 'Wives may demand it against their husbands; or husbands, if necessary, against their wives.'

${ }^{221} 27$ Edw 3 Lib Ass 49 fo 140a (1353). Seipp no 1353.174ass. Seipp commentary 'Trespass brought by the king and by a priest, and he counted how he was a priest of the king of his chapel of Westminster, and was in the king's protection, supposing that the trespass was committed against him within the Palace of Westminster in the presence of the king and of his Justices and in contempt of the king and against his protection, to the P's damage. The D denied tort and force, and whatever was against the peace, and the protection of the king, and in contempt etc., and he said that the $\mathrm{P}$ should not be received because he was villain of a certain manor, which manor he had of the lease of the prince, of whom the manor etc. until the age of an heir who was still within age, and he was seised of the manor. The P said, judgment of him as undefended, because in such case he should have defended, and have done justice etc., and although he was his villain, still he could not take him in the presence of the king, as he did. Willoughby JCP said that this was true. Therefore he told the D to answer etc., because one could not take his villain in the presence of the king.'

${ }^{222}$ See Seipp no 1481.025 (1481), see n 188 and 1481.085, see n 189. See also Putnam, n 207, p 332 quoting Marow 'Item une scole master de gramer poet chastiser cez scolers...' ('a schoolmaster may chastise his scholars').

${ }^{223}$ See 33 Hen 8 c 12 (an Act for murder and malicious bloodshed within the court). See s 6 for the exception $r e$ the master and servant.

224 See Seipp no 1348.264ass, see n 161.

225 See Seipp no 1477.022 , see n 193.
} 
[cases in 1462] ${ }^{226} 4 \mathrm{H} 71$ [case in 1489] ${ }^{227} \& 14 \mathrm{H} 78$ [case in 1498]. ${ }^{228}$ For such acts be justifiable. And see for this purpose also M Stamforde fo $13.14 .15 .^{229}$

\section{(f) Lambard - Tournaments}

Finally, Lambard stated:

If one man also hurt or kill another at fence play, or at the tilt, tournament ${ }^{230}$ or barriers (in presence of the Queen, and by her licence) or in a wager of battle for the trial of a cause according to the ancient laws of this realm, it is no breach of the peace at all. Marr. ${ }^{231}$

This statement reflected the current law that - when the Crown authorised a tournament - no battery inflicted was unlawful since the tournament permitted it. Thus, there was no breach of the peace (i.e. breach of the criminal law) although there would be in any other case.

\section{(g) Other Legal Texts}

Lambard also referred to assault in his text on Constables in $1582 .{ }^{232}$ Finally, the first legal text on criminal law, Staunford, Les Plees del Coron (1577), dealt with mayhem, ${ }^{233}$ but not with assault and battery.

In conclusion, Lambard defined assault as requiring a 'hurtful blow' (i.e. a battery) or to 'strike at a man (although he were neither hurt, nor hit, with the blow)' (i.e. an assault). Lambard also indicated various defences to a charge of assault, ones culled from the Yearbooks. viz. where a person, acting moderately (i.e. reasonably):

- $\quad$ acted in self-defence;

- $\quad$ acted to protect certain others (his wife, children, servants or villains, or they him);

- acted to protect his land or goods;

- inflicted lawful correction;

- inflicted lawful punishment, being the requisite legal authority;

- in the course of a lawful tournament.

\section{Etymology of the Words Assault and Battery}

\section{(a) Assultus}

Lambard indicated that the English word 'assault' derived from the latin 'assultus' which - it may be noted - had been used in early times to refer to battery since assault (i.e. a threatened battery) was not a crime (at least, probably, not prior to the mid- $14^{\text {th }}$ century, see 9(a)).

\footnotetext{
${ }^{226}$ See 2 Edw 4 pl 15 fo 6b-7a(1462). Seipp no 1462.015 and 2 Edw 4 pl 20 fo 8b-9a. Seipp no 1462.020 (trespass for assault, battery, wounding and imprisonment of a servant and for loss of his service).

${ }^{227} 4$ Hen 7 pl 2 fo 1b-2a (1489). Seipp no 1489.002 (trespass for assault and battery). Seipp commentary 'D pleaded that various felonies were committed in these parts where the trespass (was alleged), that $\mathrm{D}$ was watching in D's house, that $\mathrm{D}$ came out of his house, that $\mathrm{P}$ came into the high road at the hour of 10 in the night, that D came to P and thrust (ject') D's hands on P in a peaceable manner to see P's face (visage), that when D saw P and (saw) that P was a true man (voyer home), D departed and went from P, which was the assault and battery of which $\mathrm{P}$ (complained). P replied (?) that D's plea was double, the suspicion of felony and that D was a watcher for nightwalkers under the 1285 statute. .D, by an apprentice, rejoined (it was touched upon) that $\mathrm{P}$ could not traverse (deny) that D had cause of suspicion. This was denied by all the Court (that P could not traverse suspicion). Huse CJKB mentioned (touch) that watchmen could do this for the common good. And so Fairfax JKB held that watchmen could do this lawfully. But Huse CJKB and Fairfax JKB did not speak to the double pleading.'

${ }^{228} 14$ Hen 7 pl 19 fo 7b-10a (1498). Seipp no 1498.059 (trespass for assault, battery and imprisonment).

${ }^{229}$ Staunford, n 29, pp 13-5 (see folio 13 (homicide when inflicted by way of legal punishment), 14 (homicide when defending one's house or goods against robbers), 15 (homicide when by way of self-defence).

${ }^{230}$ See ns $151 \&$ 196. See also $n 287$ and Appendix G, re meaning of tilting and barriers.

${ }^{231}$ Putnam, n 207, p 333. See also Roman Law, Digest, $n 59$ see 47.10 .3 quoting Ulpian, Edict, bk 56 'if someone strike another in jest or during a contest, he will not be liable to the action for insult.' Also, Coke, n 32, vol 3, p 56 'If at a joust or tournament, or at the play with sword and buckler by the king's commandment, one does kill another, this is no felony. In the reign of king H 2 [1154-89] it was enacted, that if in such case one was slain, it should be no felony, for that in friendly manner they contended to try their strength, and to be able to do the king service in that kind, as occasion should be offered.' Coke referred to the Mirror of Justices (c. 1290), n 13, pp 31-2 (see n 993).

${ }^{232}$ W Lambard, Dueties of Constables, Borsholders, Tythingmen and such other lowe and lay Ministers of the Peace $\left(1^{\text {st }} \mathrm{ed} 1582,8^{\text {th }} \mathrm{ed} 1599\right.$, last ed, 1640). Lambard stated (I cite the 1599 ed), pp 16-7, 'these officers [i.e. constables] ought to arrest those that do make assault upon any private person; so also they may arrest any such as shall make assault (or affray) upon themselves whilst they be in doing their offices: and may for that purpose both lawfully defend themselves, and also take the offendors and commit them to the goal, or carry them to a justice of the peace, for the finding of such surety as is aforesaid....'(spelling modernized). Lambard cited 5 Hen 76 (see Seipp 1489.043, see n 194).

${ }^{233}$ Staunford, n 29, pp 38-9. He simply cited Bracton and Britton (see 7) without analysing mayhem in detail.
} 
- The latin 'assultus' ${ }^{234}$ derives from 'saltus' which referred to a jumping (or springing) out on, or the attacking of, a person. ${ }^{235}$ The latter word was closely connected to the word 'insultus ${ }^{, 236}$ - from 'insulto' to spring (or leap) at, or upon, a thing. ${ }^{237}$ Also, to the word 'assilio'- to spring (or leap) to, or on, something; ${ }^{238}$

- Hence, in latin, 'assultus' covered both assault and battery since the latin word did not necessarily connote the physical touching of a person. 'Assultus' was used in Anglo-Saxon law ${ }^{239}$ as well as in the Laws of Henry I (1100-35) $)^{240}$ and by Bracton (c. 1240). ${ }^{241}$ In law French, assultus was translated as 'assaut' or 'assault', ${ }^{242}$ as may be seen in legislation of Richard II (1377-99), for example; ${ }^{243}$

- The English word 'assault' ${ }^{244}$ - deriving from the latin 'assultus' - also possesses (like the latin) the concept of attacking someone, ${ }^{245}$

- The word 'battery' derives from the French 'battre' (to beat) ${ }^{246}$ and the Anglo-Saxon 'beatan' (to beat) and 'batt' (a club) ${ }^{247}$ - and it likely came into use in English legal language ${ }^{248}$ to help distinguish the situation between where an assault was physically effected (i.e. battery, in legal terms) and where it was not (i.e. assault, in legal terms);

- In conclusion, the Latin 'assultus' (and its many synonyms) connoted attacking or beating someone. That is, physically injuring them. This was then reflected in the Anglo-Saxon 'beatan', the French 'battre' and the English 'battery' which are translations of the same. The latin 'assultus' also covered affronting a person in terms of insulting them or threatening them.

\section{(b) Cowell - Definition of Assault}

An early English law dictionary, Cowell, in his Interpreter or Booke containing the Signification of Words (1607)

\footnotetext{
${ }^{234}$ Lewis \& Short, A Latin Dictionary ( $1^{\text {st }}$ ed 1879, OUP 1993)(definition of assultus) 'A leaping to or toward, an attack, assault.' Also, 'assulto', to jump or leap to a place, to jump or leap'. Also, 'esp[ecially] of warlike operations, to attack, assault.'

${ }^{235}$ Ibid (definition of saltus) 'a leaping, leap, spring, bound.'

${ }^{236}$ Ibid (definition of insultus) 'a scoffing, reviling, insult.'

${ }^{237}$ Ibid (definition of insulto) 'to spring or leap at or upon a thing, to leap, bound, spring, jump.'

${ }^{238}$ Ibid (definition of assilio) 'to leap or spring to or upon something.'

${ }^{239}$ Thus, the Laws of Edward the Confessor (1042-66, see O'Brien, n 7, p 170) referred to assaltu (assault). Assultus was also used in Anglo-Norman law, see e.g. JA Everard, Le Grand Coutumier de Normandie (c. 1274-8, Jersey and Guernsey Law Review Ltd, 2009), pp 310-1 'The suits are [the same] for assault and for breach of the peace' (the latin version used the word 'assaltu', the Anglo-Norman, 'd 'assault).' See also JH Baxter \& C Johnson, Medieval Latin Wordlist (OUP, 1934, rep 1955).

${ }^{240}$ e.g. Downer, n 8, p 109 (premeditatus assultus), p 267 (assultus injustus). The definition of assault in later editions of Cowell's dictionary (such as in 1708, cited here) referred to the Laws of Edward the Confessor c 12 (see n 239). Also, to 'Cart. 1 Hen 1 in Cartulary Abbat, de Radinges, MS f.1.b.. Habeant Abbas et Monachi Radingenses in tota possessione sua omnem justitiam assultu, et murdris et furtis, de sanguinis effusione et pacis infractione.' ('The abbot and monks of Bury St Edmunds may have throughout their possessions all jurisdiction for the crimes of assault, murder, theft, wounding (i.e. shedding of blood) and breach of the peace.'). This is a reference to a charter of Henry I (1100-35) to the abbot and monks of Bury St Edmunds in 1100 (reproduced in C Coates, The History and Antiquities of Reading (1802), app 1).

${ }^{241}$ See Bracton, $\mathrm{n} 10$ (online website, word search).

${ }^{242}$ Anglo-Norman dictionary (www.anglo-norman.net)(assault), to assault, attack (including verbal assault). There are variant spellings.

${ }^{243}$ See e.g. 11 Ric 2 c 1 (1387, rep) and 13 Ric 2 stat 2 c 1, 2 (1389)(rep). See Statutes of the Realm, vol 2 (on DVD, Tanner Ritchie Publishing). Other examples may be found by wordsearch.

${ }^{244}$ The OED (definition of assault, see $\mathrm{n} 245$ ) notes that the word 'asult' was altered (with an eye to the Latin) in c. 1530, to 'assault'.

${ }^{245}$ Oxford English Dictionary ('OED') (definition of assault) '1. An onset or rush upon any one with hostile intent; an attack with blows or weapons. 2. The sudden rush or charge of an attacking force against the walls of a city or fortress; a storm.3 An unlawful attack upon the person of another (in Law a menacing word or action is sufficient to constitute an assault, the term battery being tecn.[technically] added when an actual blow is inflicted). Also, 1 To make a violent hostile attack by physical means upon (a person, army etc.): to commit an unlawful or criminal assault upon the person of. 2 To attack with hostile words; to speak or write directly against.' See also e.g. 4 Jac 1 (1606-7), c 10 'suddaine assaulte and surprise of forreine enymies.'

${ }^{246} \mathrm{OED}, \mathrm{n} 245$ (definition of battery) F[rench] batterie $\left(13^{\text {th }} \mathrm{c}\right)$ 'beating, battering, a group of cannon.' Also, 'F[rench] battre to beat'. Also, '1. The action of beating or battering. A. An assailing with blows: spec[ially] in law as unlawful attack upon another by beating or wounding," including technically the slightest touch of another's person or clothes in a menacing manner. b. A mark of beating; a wound or bruise (obs). See also OED definition of 'batter.'

${ }^{247}$ See Hall, n 77, definition of 'beatan', to beat, pound, strike, thrust, dash, hurt, injure and 'batt', a bat, cudgel, club.

${ }^{248}$ The earliest citation in the OED, n 245, is in 1531. However, it was used in legislation in the time of Richard II (1377-99)('batrie'), see $\mathrm{n}$ 243. See also 1 Hen IV c 18-20 (1399), s 18 (rep). Separate references to 'assault' and 'battery' may be found in legislation such as $21 \mathrm{Jac} 1 \mathrm{c}$ 8 (1623-4), s 4 (rep) and c 16, s 3 (rep).
} 
249 stated:

Assault. insultus, cometh of the French verb (assailir i. [id est, that is]. adoriri, appetere, invadere) which French also proceedeth from the Latine (assilire, ${ }^{250}$ i. [id est, that is] assilire i. [id est] vim afferre [to bring force], oppugnare.[to beat]). ${ }^{251}$ It signifieth in our common lawe a violent kind of injurie offered to a man's person, of a higher nature than batterie. For it may be committed by offering of a blowe, or by fearefull [i.e. threatening] speech... ${ }^{252}$

Cowell also noted (in a later edition in 1708, for example):

That assault does not always imply a blow or striking, appears, in that in trespass for assault and battery, a man may be found guilty of the assault, and excused of the battery. $25 \mathrm{E}$ ca 24 [1371]. ${ }^{253}$

Cowell's definition of assault (in the first edition of this work in 1607 and in later editions) ${ }^{254}$ cited a German professor of civil law at Freiburg university, Ulrich Zasius (1461-1536). He defined assault in his work on Feuds (in 1550), as follows:

'assultus' is an attack against a person or a place, whether this be done by foot, or on horseback or by mechanical means, or by other related means (assultus, est impetus in personam aut locum, sive hoc pedibus fiat, vel equo, aut machinis, aut quacunque alia re affiliatur).

\section{(c) Later Dictionary Definitions of Assault}

Cowell's definition was subsequently adopted (in whole or part) by many other writers of law dictionaries such as:

- Doderidge (in 1631); ; $^{255}$

- Blount (whose dictionary was from $1656-1717){ }^{256}$

- $\quad$ Rastell (whose Termes de La Ley was from 1624 - 1742); ${ }^{257}$ and

- Jacob (whose dictionary was from $1729-1835$ ). ${ }^{258}$

\footnotetext{
249 J Cowell, Interpreter or Booke containing the Signification of Words (Ist ed 1607, last ed 1727). Prior to Jacob's law dictionary which was first published in 1729 (see n 258) Cowell was generally regarded as the best law dictionary. See also Holdsworth, n 168, vol 5, p 22.

${ }^{250}$ See $\mathrm{n} 238$ (assilio). Cowell took as an inspiration for his dictionary that of J Calvinus, Magnum Lexicon Juridicum (first published 1600). In his dictionary, Calvinus - while not defining assultus - defined 'assilire' as 'pro vim affere, adoriri, oppugnare, lib feud 1 tit 5 \# 1 eod[em] lib 17'. This was a reference to Ulrich Zasius. Thus, both Cowell and Calvinus referred to Zasius (see n 254).

${ }^{251}$ Lewis \& Short, n 234 (definition of oppugnare) 'to beat with fists, to buffet.' See also (definition of adoriori), 'to approach one with a hostile intent, to assault, assail'. Also, (definition of appetere), 'to attack, seize upon, assault, assail.' Also, (definition of invadere) 'to make an attack on, seize, lay hold of, attack.'

${ }^{252}$ Cowell referred to Lambard, see 10. In later editions of his dictionary (as in 1708), the wording continued: 'As to threaten a collector with harsh words, so that he dares not for fear execute his office, hath been reckoned an assault. To strike at a man, though he be neither hurt nor hit, hath been adjudged the like, 22 Lib Ass pl 60.' (see Seipp no 1348.268ass, see n 161).

${ }^{253}$ This is almost certainly a mis-reference to 45 Edw 3 c. 24 (see Seipp no 1371.058, see n 164). The 1708 edition of Cowell stated 'Assault, insultus or assultus, cometh of the French verb assayler, i.e. adoriri, invadere and that French word may be derived from the latin, assilire, that is vim affere, oppugnare. It signifies in law a violent kind of injury to a man's person, of a higher nature than battery; for it may be committed by offering a blow, or by a terrifying speech.' It cited Lambard (see 10).

${ }^{254}$ Cowell (in his dictionary in 1607): 'The Feudists call this (assultum), and define it thus: Assultus est impetus in personam aut locum, sive hoc pedibus fiat, vel equo, aut machinis, aut quacunque alia re affiliatur. Zafius de Feud parte $10 \mathrm{nu} 38$. And (assilire) est, vim adferre, adoriri, oppugnare, li[b] feud 1, tit 5 \# 1.' The Tractatus de Feudis was published in 1550. It was written by U Zasius, FS von Tautenburg \& F Sonsbeck). See generally S Rowen, Ulrich Zasius: A Jurist in the German Renaissance (Frankfurt am Mein,1987). Also, Udalricus Zasius, Opera Omnia (Sceinta Verlag Aalen. Germany 1964-6. 7 vols, rep Lyon 1550 ed).

$255 \mathrm{~J}$ Doderidge, The English Lawyer (London, printed by the assigns of I More, 1631, rep Law Book Exchange), pp 71-2, 'An assault upon a man's person by another, is so called of the latin word assultus and does import the offer of any hurtful blow or fearful speech.'

${ }^{256}$ T Blount, A Law Dictionary and Glossary ( $3^{\text {rd }}$ ed, 1717) 'Assault (assultus) is a violent injury offered to a man's person, of a higher nature than battery, for it may be committed by offering a blow, or by a terrifying speech (Lamb Eiren $1 \mathrm{~b} 1$ cap 3 [for Lambard, see 10]).' Also 'Battery (from the Fr batre, i.e. to strike, or Sax batte, i.e. fustis is a violent striking or beating a man...'

${ }^{257}$ Les Termes de la Ley or Certaine Difficult and obscure Words, and Termes of the Common Lawes of this Realme expounded. See e.g. 1708 ed. 'Assault (from the French assailer) signifies a violent kind of injury offered to a man's person, of a more large extent than battery; for it may be committed by offering a blow, or by a terrifying speech. Lamb Eiren lib 1 cap 3 [for Lambard, see 10]. Also 'Batterie is an act which tends to the breach of the peace of the realm; as when a man assaults and beats another.' Les Termes de la Ley (this title was first used in 1624) was preceded by Rastell's Exposicions of the Termes of the Law of England (Exposiciones Terminorum Legum Anglorum ) first published c. 1523 (in French). The definition of batterie is first found in the 1624 edition. See also Baker, n 169, vol 2, ch 39, John Rastell and the Terms of the Law.
} 


\section{(d) Problems with Cowell's Definition of Assault}

Cowell's definition was not very satisfactory for a number of reasons:

- Cowell defined an assault as the 'offering of a blow'. ${ }^{259}$ In this, he likely used the older meaning of the English word 'offer', being an 'attempt'. ${ }^{260}$ This was also, likely, a translation of the Latin 'vim affere' which Cowell cited in his definition. Unfortunately, subsequent writers used both the terms 'offer' and 'attempt' without noting that they were synonyms. Thus, it would have been better for Cowell to have to simply referred to an 'attempt'. That said, an assault is not an attempted battery - since a person may not intend to carry out their act (i.e. they might strike at someone with a weapon but deliberately intend to miss);

- Given this (in hindsight) Cowell should, perhaps, have defined an assault as a 'threatened battery.' However, the common law at that time also recognised 'threatening' (menacing) a person in certain instances to be a criminal offence (see Pulton in 12). Therefore, one suspects, Cowell avoided such a definition, in order not to confuse the common law on threats and assaults even though (even then) they were closely connected.

Thus, the heart of the problem vis-à-vis any definition of assault was that the common law recognised: (a) threats; (b) assault; and (c) battery, when there was a considerable overlap between (a) and (b). As it is, in modern times with common law threats no longer existing - it is appropriate to define assault in terms of a 'threatened battery'.

\section{(e) Cowell - Definition of Battery}

In his dictionary in 1607, Cowell defined 'battery' as follows:

Battery commeth of the French batre. I [id est, that is] verberare [to beat], cudere [to beat], percutere [to inflict] and signifieth in our common lawe, a violent striking of any man which the civilians call iniuriam personalem, quia persone infertur per verbera, cruciatu etc. Wesemb. parat de injuria \& fam libel [personal injury because a person is attacked by blows, torture etc. Matthaeus Wesenbecius, Paratitla in Pendectarum Iuris Civilis (1566), re injuries and libels]

In later editions, Cowell's definition of battery changed slightly, so that it read (for example in the $1708 \mathrm{ed):}$

Battery (from the French batre, to strike, or the Saxon batte, a club) is a violent striking or beating any man, for which, in regard it tends to the breach of the peace. ${ }^{261}$

\section{(f) Problems with Cowell's Definition of Battery}

One can understand why Cowell referred to 'violent' since assultus (and its many synonyms) did indeed connote the idea of attacking, striking, beating, someone.

- However, one would assert that Cowell's definition was not wholly adequate, even in his time, since no case had actually held that battery had to be violent. Indeed, Bracton (see 7) mentioned 'trifling' batteries. However, he still regarded them as batteries - although they were (he considered) too minor to trouble the royal courts with;

\footnotetext{
${ }^{258}$ G Jacob, A New Law Dictionary (e.g. $7^{\text {th }}$ ed, 1756) 'Assault (assultus) from the French verb assayler. Signifies a violent injury offered to a man's person, of a more extensive nature than a battery: for it may be committed by offering a blow, or by a terrifying speech. Lamb. Eiren. Lib 1, cap 3.'(for Lambard, see 10). Also, 'Battery (from the Fr batre to strike, or Sax. batte, a club). Is an injury done to another in a violent manner; as by striking or beating of a man, pushing, jolting, filliping upon the nose, etc.'

${ }^{259}$ OED, n 245 (blow) '1. A strike, esp a firm strike; a violent application of the fist or of any instrument to an object....3. An act of hostility...4b To strike a blow: to make an attack.'

${ }^{260}$ Ibid (definition of offer) ' 3 . An attempt, an essay at doing something, or a showing of this; the act of aiming at something, an aim (now rare or obs)'. Also '5. To make an attempt to inflict, deal, or bring to bear (violence, or injury of any kind); to put forth one's effort to make (attack, resistance).'

${ }^{261}$ Cowell, n 249 (battery). See also Lewis and Short, n 234, verbero 'to lash, scourge, whip, flog, beat.' Also, cudo 'to strike, beat, pound, knock.' Also, percutio 'to strike, beat, hit, smite, shoot etc.' The reference to Matthaeus Wesenbecius is to Matthew Wesenbeck (1531-86), a Belgian jurist who provided commentary on Justinian's Digest (also called the Pandects, see $\mathrm{n} 59$ ) in his Paratitla in Pandectarum Iuris Civilis (1566, 5 vols). This reference to striking was also found in indictments from, at least, the $14^{\text {th }}$ century (see text to Reeves, $\left.\mathrm{n} 165\right)$. ' insultum fecit, et ipsum verberavit, vulneravit, et male tractavit, etc. [he insulted him and beat him, wounded him and ill treated him etc.].' It was still a standard form in the $18^{\text {th }}$ century (e.g. JW, Officium Clerici Pacis. A Book of Indictments etc. (London, 1705), p 246). By 1826, the English translation was given by Chitty as 'did beat, bruise, wound, and ill-treat' although he noted 'it would be preferable, when only a slight assault can be proved, to frame the indictment according to the facts, and omit the latter words'. See J Chitty, A Practical Treatise on the Criminal Law (1826), vol 3, p $821 \mathrm{~b}$.
} 
- $\quad$ That said, in using the word 'violent', Cowell was probably seeking to reflect the standard wording ' $v i$ et armis' (by force and violence) which was to be found in an indictment or action for trespass for assault and battery. This went back to the need, for the purposes of the criminal law, that the battery must be contrary to the 'king's peace', in order for it to be prosecuted criminally before the king's courts.

As it is, Cowell's definition was taken up by subsequent writers who made reference to a battery having to be 'violent' in their definitions (as well as other pejorative words, such as revengeful, angry, rude, insolent, see Appendix B). Unfortunately, this mis-represented the true nature of battery since no prior text, or case, seems to have asserted a battery could only occur when the act was violent. Indeed, Bracton had only distinguished between 'trifling' batteries which the criminal law did not deal with, and serious ones which it did (see 7(e)).

\section{(g) Roman Law}

In defining assault and battery, there is something of a 'dictionary trail' - in that Cowell referred to Lambard (writing in 1581) and to Zasius (writing in 1550), as well as citing from Wesenbeck (in 1566) and Calvinus (in 1600). However, all of these writers, ultimately, were referring to the same thing - to the Digest of Justinian and, quite probably, to the words of a famous Roman jurist quoted in it, Ulpian. In chapter 47 of the Digest (Contumelies and Defamatory Writings) reference is made to a work by Ulpian (his Edicts, book 57) where he stated:

Not only he is liable for affront [for injuria] who actually inflicts it, that is, who inflicts the blow, but also he who deliberately brings it about or takes steps to ensure that a cheek be struck by a fist. ${ }^{262}$ (non solum autem is iniuriarum tenetur, qui fecit iniuriam, id est qui percussit: verum ille quoque contenetur, qui dolo fecit injuriam, vel qui procuravit, ut qui mala pugno percuteretur).(underlining provided)

The heart of battery under Roman law (excluding defamation) was, therefore, inflicting a blow, which likely accounts for Lambard (in 1597) referring to 'striking at a man' and 'hitting' as well as to Cowell (in 1607) referring to 'violent striking of any man.' The better of these definitions is that of Lambard, since 'striking' and ' hitting' a person do not necessarily have to be 'violent', though they invariably are. ${ }^{263}$

In conclusion, the word 'assault' (like its latin pre-cursor 'assultus') - with all the synonyms for both connoted the concept of 'attacking' a person, causing injury. However, the word 'assault' did not (like its latin precursor) distinguish between a blow landed and a blow threatened. Cowell's definitions of assault and battery, which were later widely cited, could have been improved on.

- Cowell defined (in 1607) battery as the 'violent striking of any man' and (in 1708) as the 'violent striking or beating any man'. In hindsight, it would have been better if he had referred to the 'unlawful striking' of a man. Or, even better, to the 'unlawful infliction of physical injury' on a man;

- Also, it would have been more helpful for Cowell to have defined 'assault' not as an attempted battery (the 'attempt' or 'offer' of a blow) but, rather, as a 'threat to commit a battery.' However, one suspects that Cowell sought to avoid the word 'threat' since there existed, in his day, a common law offence of threatening (menacing) - one separate to the offences of assault and battery - although, even in his day, threatening and assault were closely allied.

\section{Pulton (1609)}

After Lambard, the next principal writer who wrote on assault and battery, Pulton, in the first edition of his De Pace Regis et Regni (1609) commenced his work with a chapter on menaces (threats), ${ }^{264}$ assaults, batteries, (false) imprisonment and mayhems. ${ }^{265}$

\section{(a) Definitions: Assault \& Battery}

Pulton noted the close nexus between threats and assault and battery, stating:

\footnotetext{
${ }^{262}$ The Digest (see n 59) 47.10.11.1. See also Blackstone, $\mathrm{n} 400$.

${ }^{263}$ Cf. in his definition of assault, Lambard referred to a 'hurtful blow' (see 10(a)) and Cowell likely treated the word 'hurtful' as 'violent'. See also OED, n 245 (hurt) 'To knock, strike, give a blow to (so as to wound or injure).'

${ }^{264}$ Pulton, n 30, p 1. 'Undertaking to write of the peace of the king, and the kingdom, and the chief impediments thereof, and to declare which be the great and general offences, I have thought it good to begin with the very root and principal cause of the same, which are menaces, threatenings, and other bitter words, being as streams gushing out of contentious spirits, and venomous tongues, their natural fountains and spring heads, from whence do ensue sometimes assaults, batteries, routs, unlawful assemblies, forces, and forcible entries; some other times forgeries, perjuries, and oppressions; and sometimes mayhems, manslaughters, and murders.'

${ }^{265}$ Ibid, pp 1-23.
} 
Menaces, assaults and batteries be things of several natures, and yet for the most part they tend to one effect, viz. to hurt him against whom they are bent, menacing is a threatening of some hurt to be done or procured by the speaker or some other by his means to the person of the hearer, or his wife, servant, tenant or other, whereby he receives loss, or hurt.

Assault is an attempt ${ }^{266}$ to execute the thing menaced by force and violence. Battery is the performing of the thing before threatened, viz. the beating of him that was first menaced, and then assaulted. Menacing begins the quarrel, assaulting does increase it, and battery accomplishes it: menacing lays together fire and coals in the house of peace, assault blows it and makes it burn. And battery does endeavour to consume the whole building to the ground. ${ }^{267}$ (words modernised for ease of reference)

After noting the law also gave an action of trespass to one who was menaced, assaulted or beaten ${ }^{268}$ and after discussing various forms of menace, Pulton continued:

Assault and battery be for the most part an accomplishment of that which menace did threaten, and a performance by deeds of that which the other forewarned by words: that is to say, a violent and forcible abusing, or attempting to abuse by blows and stripes the person of an other, contrary to the peace of the realm, and the law of the same; which hath ordained, that no person shall be judge or revenger of his own wrong, but leave that to the censure of the law, that is always ready to hear and redress man's just complaints. ${ }^{269}$ (words modernised for ease of reference)

Pulton noted that - in the case of assault - a party could recover damages in an action for trespass with a fine to the king 'for by the assault, the party assaulted is put in fear, evil handled and hindered of his business. ${ }^{270}$

\section{(b) Defence - Self Defence \& Defending Others}

Pulton referred to the right of self-defence, with reference to various Yearbook cases:

if he that was so assaulted and beaten, did first make an assault upon him that after did beat him, and would have beaten, wounded, or etc. and in his said assault did receive from the other some stripes or blows, the defendant may justify his said assault and battery, as a thing done in defence of his own person from imminent and present peril, and wherein the law will protect and defend him... ${ }^{271}$ [i.e. self-defence]

if the plaintiff made the first assault, and the defendant in his own defence (and rather than he would be beaten or wounded) did beat, strike, or wound the plaintiff, then the plaintiff shall recover no damages against the defendant, but shall be amerced to the king for his false suit: neither shall the defendant be charged to pay to the king any fine. ${ }^{272}$ [i.e. pre-emptory self-defence]

And if one man will assault and offer to beat two, three or more persons, and they in their own defence do beat or wound him, he shall have no action of trespass or other remedy against them, and one of them may defend and help the other. ${ }^{273}$ [i.e. mutual help in self-defence]

But it is to be observed in this case, that if one man do assault an other, and if he which is assaulted may escape with his life, or without being wounded or mayhemed, it is not lawful for him to beat or wound the other who made the assault. ${ }^{274}$ [i.e. self-defence must be proportionate] (wording modernised and

\footnotetext{
${ }^{266}$ The problem with an 'attempt' or 'offer' is that it did not cover words threatening a battery, as noted in $\mathbf{1 1}$.

${ }^{267}$ Ibid, p 2. Also, p 3 'a man shall not have an action of trespass for menace only, unless he has also thereby some other loss or hurt.' See also OED, n 245 (menace) 'A declaration or indication of hostile intention, or of a probable evil or catastrophe: a threat.' Also, 'to hold out as a punishment, penalty, or danger; to threaten to inflict.'

${ }^{268}$ Pulton, $\mathrm{n}$ 30, p 4 cited the case in 1353 on threats (Seipp no 1353.136ass, see n 167). Also, 30 Ass p 14 (bill of trespass bought in the court of common pleas that, when coming towards the court to answer a plea relating to land, the D did so beat, assault and menace him that he dare not go to the court. D compelled to find pledges of his good behaviour for the peace etc.). See 30 Edw 3 Lib Ass 14 fo 176a-b (Seipp no 1356.129ass).

${ }^{269}$ Ibid, p 5.

${ }^{270}$ Ibid. Pulton cited cases in 1348 (Seipp no 1348.268ass, see n 161), 1366 (Seipp no 1366.101, see n 162) and 1368 (Seipp no 1368.025, see n 163). Also, 6 Hen 7 pl 2 fo 4lb (of 5 Hen 7) 2a (no folio 1) (1491). Seipp no 1491.011 (Appeal of mayhem. Broken bones, self defence pleaded).

${ }^{271}$ Ibid. Pulton cited cases in 1369 (Seipp no 1369.072, n 170), 1440 (Seipp no 1440.119, n 174), 1477 (Seipp no 1477.008, n 179 ), 1491 (Seipp no 1491.012, n 180) and 1455 (34 Hen 6 pl 29, fo 15b-16a. Seipp no 1455.095 (trespass for assault and battery in two counties)).

272 Ibid, p 5. Pulton cited a case in 1472 (Seipp no 1472.023, see n 178).

${ }^{273}$ Ibid. Pulton cited a case in 1400 (Seipp no 1400.041, n 172).

${ }^{274}$ Pulton cited a case in 1455 (Seipp no 1455.037, n 175).
} 


\section{divided for ease of reference)}

In respect of defending others, Pulton stated:

As the law does account it no breach of the peace for one man to beat an other in the defence of his own person from killing, wounding, or beating, but a thing justifiable, so does she impute it no fault punishable for the husband to beat him, that does assault and would beat, wound, or evil intreat his wife, being of one flesh... (words modernised for ease of reference)

Pulton then made the same proposition in respect of a:

- $\quad$ wife protecting her husband;

- son (or daughter) protecting their parents;

- parents protecting their son (or daughter) within age and unable to defend themselves;

- lord protecting a villain; or

- $\quad$ servant protecting his master (or mistress). ${ }^{275}$

\section{(c) Defence - Defence of Goods \& Land}

Pulton stated in respect of a man defending his possessions:

As the law does allow a man to beat another in defence of his person, from extreme peril: so does she tolerate one man to beat another for the preservation of his goods from rapine and spoil: for as it stands not with the peace of the realm, that one man without some lawful cause should beat another: so it stands not with the justice of the realm, that one man should take another's goods injuriously from him. And he that will attempt by force and violence to take away another man's goods wrongfully from him, may justly by force and strong hand be resisted: and if in that case he that shall make an assault to take those goods, be in the encounter beaten by the owner of the same goods, the law will excuse the owner therein, and protect him to defend those goods, whereof he has a lawful property... ${ }^{276}$

And the same law is, if a man has no property in goods, but only possession by the bailment of another, to be re-delivered when they shall be required: if in this case a stranger will assay by force to take the same away, he that has possession of the same goods (though it be but a bloodhound) may defend the same by force: and if the said stranger shall be hurt or beaten in the assault, he shall have no remedy by action of trespass, or otherwise, against him that has the said possession, for he may justify the defence of the goods so bailed unto him, in respect that he has the lawful possession of them, and stands chargeable to re-deliver them, or the very value of them to him, who bailed them unto him, whensoever he shall be required. ${ }^{277}$ (wording modernised for ease of reference)

In respect of a man's defending his land, Pulton stated:

And so it is if one has a mill whereunto a river or spring of water does run, and has run time out of the remembrance of man, and another would stop the course of that water, and turn it another way, and the owner of the mill does disturb him therein, whereupon that other does assault and attempt to beat him: in this case, if the owner of the mill for his own safeguard, and for the defence of his ancient watercourse, does beat him again, it is justifiable: for this beating was not an intended breach of the peace, but to defend him from violence offered to his person, and injury to his freehold or term.

And the same law is in every case of battery of another, who does menace or assault the right owner, and attempt to beat him for the lawful defence of his own freehold, or term, or from his lawful highway. ${ }^{278}$ (wording modernised for ease of reference)

\section{(d) Defence - Lawful Correction}

As to a schoolmaster and pupil, Pulton stated:

In an action of trespass of assault and battery, it is a good plea for the defendant to plead, that he is a schoolmaster, and a teacher and instructor of children, and that the plaintiff put himself to be scholar

\footnotetext{
${ }^{275}$ Pulton, with reference to caselaw, went into considerable detail about the master and servant (including the master's remedy if someone beats his servant).

${ }^{276}$ Pulton cited the cases in 1440 (Seipp no 1440.077, n 183), 1469 (Seipp no 1469.085, n 184) and 1441 (Seipp no 1441.029). Also, a case in 1506, see Keilw 92 (72 ER 255)(justifiable assault re re-possession of a horse).

${ }^{277}$ Pulton, n 30, p 6.

${ }^{278}$ Ibid, Pulton cited a case in 1402 (Seipp no 1402.003, n 181) and in 1470, see 10 Edw 46 (see n 185).
} 
with him, and to be taught and instructed in his book[s]; and because the plaintiff was careless and negligent in learning of that whereof he was instructed, or did beat and abuse other scholars his school fellows, the defendant did beat him with a rod, as it was lawful for him to do. ${ }^{279}$ (words modernised for ease of reference)

As to a master and his apprentice, Pulton stated:

In an action of trespass and battery it is a good plea for the defendant to plead, that he is a free man of the city of London, occupying the trade of a draper: and that the plaintiff being above the age of 14 years, put himself apprentice unto him, to serve him in that trade, by the space of 7 years: and because the plaintiff was negligent in learning his trade, he did strip him, and beat him with a rod, and it was lawful for him to do: and if he did not sufficiently beat him for his offence at one time, he may beat him again... ${ }^{280}$

As to a master and his servant, Pulton stated:

In an action of trespass of assault and battery, the defendant pleaded, that the plaintiff was his servant retained, and departed out of his service, and that he laid hold upon him, and led him home to his house to do his service: but this was adjudged no plea; for it is not lawful for the master in this case to beat, or forcibly to compel his servant against his will to return and do his service; but to require him to do it, and if he will not, then the master may have an action of covenant against his servant, and recover so much in damages, as he has received hinderance by his loss of service ${ }^{281} \ldots$...and as the master cannot by beating, nor by force compel his servant, to serve him against his will: no more can a lord compel his ward, by beating, or by force to come unto him, or to tarry with him against his will: but if he do depart from him, then his lord is to have his action against him. ${ }^{282}$ (words modernised for ease of reference)

As to a madman, Pulton stated:

If a man be frantic, furious, or mad, and attempts being at liberty to burn a house, or to do some other mischief, or to hurt himself, or others: it is lawful for his parents, kinsmen and other friends, to take him, put him into a house, to bind him, and to beat him with rods, and do any other forcible act to reclaim him, or to keep him in a house or place alone, where he shall do no hurt: and he shall have no action of trespass or assault and battery, action of false imprisonment, nor other remedy against them: for in this case, and the others before rehearsed, the peace of the realm was not broken, but a lawful punishment was inflicted upon those who had deserved it, to the end they should be reformed, and hereafter do their duties the better. ${ }^{283}$ (words modernised for ease of reference)

\section{(e) Defence - Legal Justification}

Pulton stated:

If one man do make assault upon another attempting to beat him, and so to break the peace, if a justice of peace do command him who makes the assault to keep the peace and to surcease his assault, and he will not do it, or will answer that he will not: the justice of the peace may lay his hands upon the offender, and arrest him to find sureties of his good behaviour: and if the offender do make rescue, and resist the arrest by force, and then be beaten, he shall have no remedy against the same justice of peace, who has done nothing but that which belonged to his office and duty: and the offender first in breaking the peace, and after in resisting the justice of the law, being beaten by the justice of the peace, or any other in his company, has worthily tasted the due reward of his own disobedience. And also the justice of the peace may in this case commit the offender to prison, until he has found sureties to keep the

\footnotetext{
${ }^{279}$ Pulton, n 30, p 6. Pulton cited a case in 1481 (see Seipp no 1481.025, see n 188).

${ }^{280}$ Pulton continued 'Some do hold that if an apprentice or servant be above the age of 21 years, and then do his service negligently, that his master ought not to beat him therefore, but to have an action of covenant against him. But note the form of the indenture of an apprentice touching [i.e. concerning] chastising him: and it appeareth by the statute of $33 \mathrm{H} 812$ (see n 223) that the master may strike his servant with his hand, fist, small staff, or stick for correction, and though he do draw blood.' See also T Smith, De Republica Anglorum (1583), p 140 '[an apprentice] must suffer such correction as his master shall think meet'.

${ }^{281}$ Pulton, $\mathrm{n} 30$, p 7 cited a case in 1460 (38 Hen 6 pl 2, fo 25a-b. Seipp no 1460.010). Also, 5 Eliz 4 (punishment of servants who refused to work). See 5 Eliz 4 (1562-3) An Act touching divers orders for artificers, labourers, servants of husbandry and apprentices. See s 6 for refusal to serve.

${ }^{282}$ Pulton cited the cases of 38 Hen 625 (Seipp no 1460.010, see n 186) and 22 Ass p 85 (22 Edw 3 lib ass 85 fo 104b-105a, 1348.293ass (wardship)).

${ }^{283}$ Pulton cited the cases of 22 Lib Ass 56 (Seipp no 1348.264ass, see n 187) and 22 Edw 445 (Seipp no 1483.010, see n 191).
} 
peace: a justice of peace may arrest one to find surety of peace, and though he does let the same party after to go at liberty, without finding surety of peace, yet he shall have no action or other remedy to punish the same justice, because he is justice of record. ${ }^{284}$

If one man enter a plaint against another in a court having jurisdiction to hold plea of that suit, and the sarjeant of the court does arrest the defendant, and the defendant will draw his sword to defend himself, and after does run away, with intent to escape from the sarjeant, if in this case, the sarjeant and he that did enter the plaint, do pursue him, beat, and hurt him, if he will not be apprehended and yield to the arrest, they may justify the same in an action of trespass of assault and battery; for they have not broken the peace, nor offended the law, in seeking to justify him, who does attempt to fly from the justice and indifferent trial of the law. But if the party had not been arrested, the sarjeant, nor any other with him could have justified the beating of him. ${ }^{285}$

In an action of trespass of assault and battery, is a good plea by the defendant to plead, that he had a warrant to arrest the plaintiff, and that by force of that warrant he did arrest him, and then the plaintiff made assault upon him, and therefore the hurt which he received, was by his own assault: for every subject is bound to obey the king's writs and all mandates, precepts and warrants awarded by his justices, sheriffs and officers sufficiently authorised: and he that does resist them, or denies to obey them, encounters the justice of the law; and therefore the beating of him who refuses to submit himself to the obedience of the law, is no breach of the peace, but a means to perform the law. ${ }^{286}$ words $^{2}$ modernised for ease of reference)

\section{(f) Defence - Consent}

Pulton stated:

If two or more do agree together to run at tilt, joust, barriers, or to play at backsword, bucklers, [i.e. jousting or fencing] ${ }^{287}$ football, or such like, and one of them does beat, bruise, or wound an other; the party grieved shall not have an action of trespass of assault and battery against the other; for that it was a combat by consent, and put in practice to try their strength, valour, or agility, and not to break the peace.

But if the same day or some other after that the pastime is at an end, and they departed asunder, one will assault or beat an other, in respect of some wrong conceived to be received in the time of the said play; then an action of trespass of assault may be pursued by him that is so beaten against the trespasser. ${ }^{288}$ (wording divided for ease of reference).

Pulton appears to have been one of the first legal writers (if not the first) to argue that battery by 'consent' was a defence, other than in the case of a lawful tournament.

- Prior to this, it is asserted that it is unclear whether 'consent' ever was a defence. Rather, the issue was 'was there intended a breach of the peace'? If the battery was minor, since Bracton (c. 1240) the criminal courts had ignored minor batteries. And, in the case of licensed tournaments, more serious batteries were non criminally liable on the basis that that a tournament was a martial activity and, thus, martial (military) law applied;

- One can understand why the concept of 'consent' was applied (and needed) since other games such as football were being played. However, it is important to note that the logic behind 'consent' was that only minor batteries were excepted. Thus, any game where there was an intent to commit serious batteries (such as an unlawful tournament, or duel) would have been subject to the criminal law.

In conclusion, for Pulton, assault was an 'attempt to execute the thing menaced by force and violence' and battery was the actual 'beating of him that was first menaced.' The defences which Pulton listed in 1609 were similar to those of Lambard in 1581 (albeit, more detailed).

\footnotetext{
${ }^{284}$ Pulton cited 9 Edw 43 (Seipp no 9 Edw 4 pl 10 fo 3a. 1469.030 (trespass for assault and battery, JP) and 21 Hen 722 (21 Hen 7 pl 22 fo $32 b$ Seipp no 1505.022 (surety of the peace)).

${ }^{285}$ Pulton, $\mathrm{n}$ 30, pp 6-7.

${ }^{286}$ Pulton, n 30, p 8, cited 21 Hen 739 (Seipp no 1505.051, see n 195) and Fitzherbert, n 18 (title Trespass) 108.

${ }^{287}$ OED, n 245 (barriers) 'The palisades enclosing the ground where a tournament, tilting, or other martial contest or exhibition was held, the lists. Hence, the expression to fight at barriers, and barriers, as the name of a martial exercise in the $15^{\text {th }}$ and $16^{\text {th }}$ centuries.' (bucklers) 'to play at bucklers, at sword and buckler; to fence.' (back-sword) 'A stick with a basket-hilt, used instead of a sword in fencing, a single stick hence b. fencing exercise with it'.

${ }^{288}$ Pulton, n 30, p 7 cited Fitzherbert, n 18 (title Barre) 244.
} 


\section{Dalton (1619)}

Dalton, The Countrey Justice, was a popular work from when it was first published in 1618 until the final edition in 1746, when it was superseded by the (equally) popular text of Hawkins (see 14). Further, it is noteworthy that the wording in Dalton in respect of assault and battery from the first edition in1618 until the last edition in 1746 (128 years' worth) changed very little (as I indicate in the footnotes).

\section{(a) Assault \& Battery}

Dalton dealt with assault and battery in the context of the forfeiture of recognizances given for surety of the peace. Thus, in the second edition of his work (1619), ${ }^{289}$ he stated:

And first this breach of the peace may be committed by using any fearful or threatening speeches to another: Therefore all menacing or threatening to kill, or beat another, to his face, is a forfeiture of this recog[nizance] otherwise if the party so threatened, be absent; and yet if the party so bound, shall threaten to kill or beat A who is absent, and after shall lie in wait for him to kill or beat him, this is a forfeiture of his recognizance. ${ }^{290}$ So assaults etc. to strike at, or offer to strike at, a man, although he never hurt, not hit him, is a forfeiture of this recognizance. ${ }^{291}$ (spelling modernised)

Then, without defining battery, Dalton mentioned various offences which also resulted in a forfeiture of a recognizance. He stated:

All imprisonment, or arresting of another, without warrant, is a forfeiture of this recognisance. So to thrust another into the water, whereby he is in danger of drowning. So to ravish a woman against her will [i.e. rape]. So to commit any burglary, robbery, murder, or manslaughter, all of which are to the person of another, or to procure the same, all and every of these are forfeitures of this recognizance. So to do any treason against the person of the king.

However, by the final edition of his work in 1746, Dalton had stated:

Battery is the wounding or beating another. Assault is, when one unlawfully sets upon the person of another, offering to beat him, although he beats him not, or striking at him, though he strikes him not. 292 (bold provided)

\section{(b) Defences}

Dalton stated (in the 1619 edition of his work):

Also though assaults and batteries be for the most part contrary to the peace of the realm, and the laws of the same, yet some are allowed to have a natural, and some a civil power (or authority) over others; so that they may (in reasonable and moderate manner only) correct and chastise them for their offences, without any imputation of breach of the peace; yea they may (by the law) justify the same. ${ }^{293}$ (wording modernised)

Dalton then cited the same defences as Pulton, viz.

- $\quad$ Self Defence \& Defending Others. It was no breach of the peace (i.e. battery) for a private man to beat, strike, or wound another in defence (and safeguard of) his own person, from killing, wounding, or beating. ${ }^{294}$ Further, it was no breach of the peace for a man to beat a person who assaulted (and would beat or wound or evil entreat) his wife, father, mother or master. ${ }^{295}$ Further (possibly) a master might

\footnotetext{
${ }^{289}$ The first edition in 1618 was amended by the $2^{\text {nd }}$ edition in 1619 and so the latter tends to be cited.

${ }^{290}$ Dalton, n 31, p 160. Dalton cited Lambard and 18 Edw 428 (see 18 Edw 4 pl 24 fo 27b-28a. Seipp no 1479.024) noted in Brooke, n 19 (title Peace) no 16. In the 1746 version of Dalton (the last edition) the wording in the text was very similar.

${ }^{291}$ Ibid. Dalton cited Crompton (see n 27) and continued 'Much more all affrays, or violent and malicious batteries, strikings, beatings, woundings, or other misintreatings of the person of another, are forfeitures of this recognizance. The difference of these 3 are, menacing begins the breach of the peace, assaulting increases it, and battery accomplishes it.' (spelling modernised). In the 1746 version the wording was very similar.

${ }^{292}$ Dalton, n 31 (1746 ed), p 281

${ }^{293}$ Ibid, n 31, p 161.

${ }^{294}$ Ibid. Dalton continued, p 162 'yet it seems if another shall assault me, if I may escape with my life, or without being wounded, maimed or hurt, it is not lawful for me to beat or wound the other, who first made the assault, but I must first fly, or go from him so far as I can.' (spelling modernised). Dalton cited, inter alia, (a) 2 H 48 (Seipp no 1400.041, see n 172); and (b) 33 Hen 618 (Seipp no 1455.037, see n 175). The wording in the 1746 edition of Dalton was almost identical.

${ }^{295} \mathrm{Ibid}, \mathrm{pp} 162-3$ 'Also it is no breach of the peace for a man to beat him, that does assault and would beat, wound or evil intreat his wife, father, mother, or master, but is justifiable. So if the wife shall beat him that shall assault, and would beat or evil intreat her husband. So if the father, or mother, shall beat him that does assault and would beat, or evil entreat their child, being then within age, and not able to defend itself. But
} 
beat another in defence of his servant. ${ }^{296}$ However, a fermor (or tenant) could not justify an assault or battery in defence of his landlord, nor could a citizen in defence of the mayor (or bailiffs) of the city (or town) where he dwelt; ${ }^{297}$

- Defending Goods \& Land. The law allowed a man to beat another for the 'preservation of his goods'. ${ }^{298}$ The same applied in respect of one's land; ${ }^{299}$

- Legal Correction. A parent (with moderation) might chastise his children within age. ${ }^{300}$ So too, a schoolmaster his scholars. He might chastise a scholar who was careless and negligent in learning, or who abused his schoolfellows, or for other the like occasions; ${ }^{301}$ A master might (with moderation) chastise his servant or apprentice. ${ }^{302}$ A man might chastise any kinsman that was mad etc. ${ }^{303}$ Dalton observed 'it is lawful for the parents, kinsmen, or other friends of a man that is mad, or frantic (who being at liberty attempts to burn a house, or to do some other mischief, or to hurt himself, or others) to take and put him into a house, to bind or chain him, and to beat him with rods, and to do any other forcible act to reclaim him, or to keep him so as he shall do no hurt.' 304 A gaoler (or his servant by his commandment), might chastise his unruly prisoners; 305

- Legal Justification. A constable might be legitimately forced to strike any person who would not yield to their arrest or who resisted arrest or fled from it. ${ }^{306}$ Assault and battery might also be imposed by way of legal punishment; ${ }^{307}$

though the servant may lawfully beat him that does assault, and would beat, or evil intreat his master, or mistress; yet the servant cannot justify the beating of another in defence of the father, mother, brother, sister, son or daughter of his master or mistress, for he owes no obedience or duty to any of them.' (spelling modernized). The wording in the 1746 edition was almost identical.

${ }^{296}$ Ibid, p 163 'By some opinions the master cannot justify the beating of him that does assault, and would beat his servant; but the master with a sword, staff, or other weapon may defend his servant assaulted from being beaten, in respect of the loss of his service: yet master Lambert and master Crompton are of the opinion that the master may beat another in defence of his servant.' (spelling modernised). Dalton cited Lambard (see 10) and Crompton (see $\mathrm{n}$ 27). The wording in the 1746 edition was almost identical.

297 Ibid, p 163. Dalton cited Lambard (see 10). The wording in the 1746 edition was almost identical.

298 Ibid, p 163 'Also the law does tolerate a man to beat another for the preservation of his goods: and therefore he that shall attempt by force and violence, to take away my goods wrongfully from me, whether they be goods whereof I have a lawful property, or such goods whereof I have only a possession by the bailment of another, I may justify to defend the same by force, and if I shall hurt or beat such person, it is no breach of my recog[nizance] for the peace; but if I kill him, it is felony, and then a breach of the recog[nizance].' (spelling modernised). Dalton cited: (a) 9 Edw 428 (Seipp no 1469.085, see n 184); (b) 19 Hen 631 (Seipp no 1440.077, see n 183). The wording in the 1746 edition was almost identical.

${ }^{299}$ Ibid, p 163 'The same law is in every case, where another shall attempt by force to take away my land, freehold, copyhold, or lease; or to stop or turn my lawful highway, or my ancient river, or watercourse leading to my mill; in these and like cases, if I shall disturb him therein, whereupon he does assault and attempt to beat me, I may justify to beat him again, as well in defence of my person, as of my possessions, but not to kill him.' (spelling modernized). Dalton cited: (a) 10 Edw 46 (in 1470, see n 185); (b) 3 Hen 49 (see Seipp no 1402.003, see n 181) and (c) 11 Hen 633 (this would appear to be 11 Hen 6 pl 23 fo 33a-34a. Seipp no 1433.045 (trespass for taking animals)). The wording in the 1746 edition was almost identical.

${ }^{300}$ Ibid. p 161 'And therefore the parent (with moderation) may chastise his child within age.' (spelling modernized). Dalton did not cite any authority. However, see Lambard (see 10). The wording in the 1746 edition was almost identical.

${ }^{301}$ Ibid. 'So may the schoolmaster his scholars.' At p 162 'Also the schoolmaster, with a rod, may chastise his scholar, which is careless and negligent in learning, or that shall abuse his schoolfellows, or for other the like occasions.'(spelling modernized). The wording in the 1746 edition was almost identical.

${ }^{302}$ Ibid, 'So may the master his servant or apprentice.' Dalton also stated, p 161 'Note that the master may strike his servant with his hand, fist, small staff, or stick, for correction; and though he do draw blood thereby, yet it seems no breach of peace, as appears by the statute of $33 \mathrm{H} 8$ ca 12 [see n 223]. And where the servant shall be negligent in his service, or shall refuse to do his work etc. there the master may chastise his servant for such negligence or refusal; so [long] as he does it not outrageously. But if the servant shall depart out of his masters service, and the master happen after to lay hold of him, yet the master in this case may not beat, or forcibly compel his said servant, against his will to return, or tarry with him, or do his service, but either he must complain to the justices of peace for his servant's departure; or he may have an action of covenant against his servant, if being required to do his service he shall refuse it. And as the master without the breach of the peace, cannot by beating or force, compel his servant to serve him against his will: no more can a lord, or guardian in chivalry, compel his ward, by beating, or by force, to come unto him or to tarry with him against his will.' (spelling modernized) . The wording in the 1746 edition was almost identical.

${ }^{303}$ Ibid, p 161. 'So may any man his kinsman that is madde etc.' Dalton referred to cases in 1348 , see n 187 and 1483 , see ns $190-1$. The wording in the 1746 edition was almost identical.

304 Ibid, p 162. The wording in the 1746 edition was almost identical.

${ }^{305}$ Ibid, p 161 'So may a goaler (or his servant by his commandment) [chastise with moderation] his unruly prisoners.' (spelling modernized). Dalton cited no authority. The wording in the 1746 edition was almost identical.

${ }^{306}$ Ibid, p 162 'Also if a constable, sarjeant, bailiff or other officer of justice or any other being of their company, for the better executing of their office, shall be forced to strike any person, that will not yield to their arrest, or that shall resist, or fly from their arrest, they shall not be in any danger to forfeit any recog[nizance] of the peace by any such assault, or striking, but may well justify such act.' (spelling modernised). 
- Consent. It was not against the peace if two (or more) agreed to play barriers, back-sword, bucklers, ${ }^{308}$ football or the like and one wounded, or hurt, another. ${ }^{309}$

Finally, it may be noted that Coke, in his Institutes of the Laws of England (1618-41), did not deal with assault and battery in any detail. ${ }^{310}$ Nor did Sir Matthew Hale in his History of the Pleas of the Crown (published in 1736 but written in the 1670 's) ${ }^{311}$ although definitions of assault and battery were provided in other $17^{\text {th }}$ century legal texts such as Sheppard, The Faithful Counsellor (1653) ${ }^{312}$ and Hughes, Abridgment (1675). ${ }^{313}$

In conclusion, Dalton closely followed Lambard and Pulton in defining assault and battery - as well as the categories of defence.

\section{Cases: 17th -18 th Century}

In the period between when Dalton first wrote (1618) and when Hawkins first wrote (1716) there were a number of cases relating to assault and battery of importance - not least since they tended to be much cited in legal texts thereafter. However, most of these cases comprised the tort, rather than the criminal offence of assault and battery. These cases comprise:

\section{(a) Assault}

- $\quad$ Turberville v Savage (1669) ${ }^{314}$ An action for assault, battery and wounding. The court held that, if a man lay his hand upon his sword and say, 'If it were not assize time, I would not take such language' it was not an assault. Also 'if one strike another upon the hand, or arm, or breast in discourse, it is no assault, there being no intention to assault; but if one, intenting to assault, strike at another and miss him, this is an assault: so if he hold up his hand against another in at threatening manner and say nothing, it is an assault.';

- Anon (1674) ${ }^{315}$ D drew a sword and waived it in a menacing manner at P, but did not touch P. This was held to be an assault.

These cases comprise useful examples of the essence of assault, a threat (by words or gesture) to inflict unlawful physical injury on another, a threat not thereafter executed.

\section{(b) Battery}

\footnotetext{
Dalton referred to Staunford, n 29, pp 13-4 (see n 229 )and 21 Hen 739 (see Seipp no 1505.051, see n 195). The wording in the 1746 edition was almost identical.

${ }^{307}$ Ibid, p 163 'The same law is also in every case, where an offender is by order of law punished with whipping, stocks, pillory, or otherwise, for any offence by him committed contrary to the laws or statutes of the realm, there is no peace broken, nor any recog[nizance] of the peace forfeited, by him or them which shall lawfully excuse such punishments.' (spelling modernised). The wording in the 1746 edition was almost identical.

${ }^{308}$ OED, n 245 (barriers), OED (backsword), OED (bucklers).

${ }^{309}$ Dalton, n 31, p 162 'If two or more agree together to play at barriers, back-sword, bucklers, foot-ball, or such like, and one of them does wound or hurt another, the party hurt shall not have an action of trespass therefore against the other, for that it was by consent, and to try their valour, and not to break the peace.'(spelling modernised). Dalton cited Fitzherbert, n 18 (title Barre) no 244. Dalton continued 'Yet if such a man were before bound to the peace, such act seems to be a forfeiture of his recognizance: see Br[ooke] Coron 229 [see $\mathrm{n}$ 196] for although such sports be suffered, yet they are not lawful.' The wording in the 1746 edition was almost identical.

${ }^{310} \mathrm{Cf}$. Coke, $\mathrm{n}$ 32, vol 2, p 315 'There is also another diversity between an appeal of mayhem, or an action of trespass for wounding, or mannas of life and member; and an action of trespass of assault and battery for a man in defence, or for the preservation of his possession of lands or goods; for in that case he may justify an assault and battery; but he cannot justify either mayheming, or wounding, or mannas of life and member: and so note a diversity between the defence of his person, and the defence of his possession and goods.'(quotation from 1824 ed).

${ }^{311}$ Hale, n 33, pp 485-6 (entering the possession of another, where justifiable, where not). He stated 'If A pretending a title to the goods of B take them away from B as a trespasser B may justify the beating of A but if he beat him so that he die, it is neither justifiable, nor within the privilege of se defendendo, but it is manslaughter. Hale cited Dalton. Also, 'A is in possession of the house of B. B endeavours to enter upon him, A can neither justify the assault nor beating of B for B had the right of entry into the house, but if A be in possession of a house, and B as a trespasser enters without title upon him, A may not beat him, but may gently lay his hands upon him to put him out, and if B resist and assault A then A may justify the beating of him, as of his own assault.' Hale did not deal with assault and battery in his Pleas of the Crown, seen $\mathrm{n} 33$. ${ }^{312}$ W Sheppard, The Faithful Councellor or the Marrow of the Law (printed by R W, 1653), p 280 'Assault (which is) where one does unlawfully set upon and attempt to beat another, but does it not. Battery (which is) when one does unlawfully beat another.'

${ }^{313}$ Hughes, n 20 (definition of battery) 'Battery signifieth a violent striking of any man, or a personal wrong.'

3141 Mod 3 (86 ER 684). Buller, n 37, p 15 'These words would prevent the action from being construed to be an assault, because they shew he had no intent to do him any corporal hurt at that time.' See also T Weir, An Introduction to Tort Law (2 ${ }^{\text {nd }}$ ed, 2006), p 137 (who noted that the assault point was actually raised by the defendant). See also T Weir, A Casebook in Tort (10 $\left.{ }^{\text {th }} \mathrm{ed}, 2004\right), \mathrm{p} 325$.

3151 Vent 256 (86 ER 171).
} 
- Weaver $v$ Ward (1627) ${ }^{316}$ An action for assault and battery. D accidentally discharged a musket, wounding a fellow soldier. He was found (in effect) guilty of negligence. Reference was also made to the fact that - if the act had been consensual or accidental - an action would not have succeeded; $;{ }^{317}$

- $\underline{\text { Anon (1638) }}{ }^{318}$ An action of trespass and battery. A man whipped a horse with a twig, causing the rider to fall and be injured;

- Dodwell v Burford (1670) ${ }^{319}$ An action for battery. It was held a battery when a person on a horse was thrown and injured, after his horse was (deliberately) struck;

- Dickinson v Watson (1682) ${ }^{320}$ An action for assault, battery and wounding. D discharged a pistol, injuring P. It was held that a justification (defence) was of no avail in trespass without unavoidable necessity [i.e. by proving it was an accident]. Judgment was given for the $\mathrm{P}$;

- Gibbons v Pepper (1695) ${ }^{321}$ An action for assault and battery. D whipped a horse which then ran down and injured the P. Held D liable; ${ }^{322}$

- Cotesworth (1704) ${ }^{323}$ Spitting in a person's face was a battery; ${ }^{324}$

- Cole v Turner (1704) ${ }^{325}$ In this case, Holt CJ stated: 'First, that the least touching of another in anger is a battery. Secondly, if two or more meet in a narrow passage, and without any violence or design of harm, the one touches the other gently, it will be no battery. Thirdly, if any of them use violence against the other, to force his way in a rude inordinate manner, it will be a battery: or any struggle about the passage to that degree as may do hurt, will be a battery'. It is asserted that this dictum must be understood against the background of the law in Holt's time. In 1704, when he wrote, the royal courts would only have had cognizance of batteries in 'breach of the peace'. Thus, if there was no intent to commit a breach of the peace, the act would not have been subject to the criminal law. This was re-inforced in part by the indictment containing the words ' $v i$ et armis' (by force and violence) (see also 11(f)). However, the terse formulation of Holt CJ, unfortunately, led later legal writers (notably Hawkins) to subsequently make anger (or revenge or hostility) a pre-requisite for battery, when this was not previously so. There needed be no emotional element to the same;

- Ingram \& Ux (1711) ${ }^{326}$ An indictment against a husband and wife for an assault and battery. Parker CJ stated: 'there cannot be a battery and wounding without an assault, though there may be the latter without the former'.327

\section{These cases confirmed a long established principle that assault or battery - if accidental - did not constitute a crime. Cole $v$ Turner is problematic in that it is inaccurate. Battery was not restricted to the infliction of angry}

\footnotetext{
${ }^{316}$ Hob 134 (80 ER 284). See also, in respect of this case, Baker \& Milsom, n 187, pp 331-3 and Baker, n 160, p 404. See also, for an explanation of this case, Croom-Johnson LJ in Wilson v Pringle (1986)(see 30), p 246 'The defendant could not be excused of trespass 'except it be judged utterly without his fault'. In other words the defendant would be liable in trespass if he acted negligently, even though he had no intention to shoot the plaintiff. Nowadays an action such as that could only be brought in trespass on the case, in negligence.'

${ }^{317}$ Cf. p 134 'though it were agreed, that if men tilt or turney [tournaments] in the presence of the king, or if the masters of defence playing their prizes [i.e. fencing] kill one another, that this shall be no felony... yet in trespass, which tends only to give damages according to hurt or loss, it is not so...'. Also, 'if here the defendant had said, that the plaintiff ran cross his piece when it was discharging, or had set forth the case with the circumstances, so as it had appeared to the court that it had been inevitable, and that the defendant had committed no negligence to give occasion to the hurt.' For 'tilting' and 'tournaments' which were permitted by the king, see n 151.

${ }^{318}$ W Jon 444 (82 ER 233).

3191 Mod 24 (86 ER 703). See also FA Trindade, Intentional Torts: Some Thoughts on Assault and Battery (1992) 2 Oxford Journal of Legal Studies, p 217.

${ }^{320}$ Sir T Jones 205 (84 ER 1218)

$3214 \operatorname{Mod} 505$ (87 ER 469).

${ }^{322}$ Per curiam 'if I ride upon a horse, and JS whips the horse, so that he runs away with me and runs over any other person, he who whipped the horse is guilty of the battery, and not me. But if I by spurring was the cause of such accident, then I am guilty. In the same manner, if A takes the hand of $\mathrm{B}$ and with it strikes $\mathrm{C}, \mathrm{A}$ is the trespasser and not B.' Buller, $\mathrm{n} 37, \mathrm{p} 16$ cited this case and noted:' quaere, in the other case, if the $\mathrm{P}$ were to prove that the horse had been used to run away with his rider, for in such case the rider is not free from blame [i.e. he is negligent].' He noted that there would be no trespass if the horse ran away with his rider on a sudden fright and injured someone, since it was accidental.

3236 Mod 172 (87 ER 928).

${ }^{324}$ Holt CJ at p 172 'It is a battery.'

${ }^{325} 6$ Mod 149 (87 ER 907). See also Holt 108 (90 ER 958). The cases cited to Holt in the reports do not directly support a pre-requisite for 'violence'.

326 Salk 384 (91 ER 335).

${ }^{327}$ At $\mathrm{p} 335$.
} 
(or violent) physical injury on another. It could also occur without violence or anger. The case report is scant and so Holt's views may not have been well reported.

\section{(c) Defence - Self-Defence \& Defence of Others}

- Marler $\boldsymbol{v}$ Ayliffe \& Evlett (1606) ${ }^{328}$ An action of trespass for taking a gun and dagger from P. One of the D's justified this because P had assaulted one JS with them and - in preservation of the peace and for safeguarding the life of JS - he took them from P and so was justified. The jury found P guilty and assessed costs;

- Dause v Luce (1665) ${ }^{329}$ An action for trespass for assault, battery, wounding and mutilation. D pleaded self-defence. It was held to be a good plea. The court noted that: 'the defence must be proportionate to the assault as laid'. ${ }^{330}$ Twisden $\mathrm{J}$ also noted that: 'the assault must be such, as is [a] just ground of terror [apprehension] as by holding up a sword'; 331

- Leward v Basely (1694) ${ }^{332}$ It was held that a wife may justify an assault in defence of her husband and a servant in defence of his master;

- Cockcroft v Smith (1705) ${ }^{333}$ An action for assault, battery and mayhem. Holt CJ stated: 'for every assault he did not think it reasonable a man should be banged with a cudgel' (i.e. self defence should be proportionate). ${ }^{334}$ In this case a court clerk (during a scuffle) pointed a finger towards the D's eye. D then bit it off.

These cases confirmed that any self-defence, and defence of others, should be proportionate.

(d) Defence - Defence of Possessions

- Lee v Atkinson \& Brooks (1609) ${ }^{335}$ Action for battery for assaulting P (pulling him off a horse) and for beating, wounding and evil treating him. It was held that - if a person hired a horse for a certain time to go to a particular place - the owner could not justify re-taking the horse violently within that time, although the hirer went to a different place;

- Seaman v Cuppledick's Case (1614) ${ }^{336}$ An action for assault and battery. It was held that a master could act to defend his servant;

- Skevill v Averv (1628) ${ }^{337}$ An action for assault, battery and wounding. D may justify that he was possessed of a house, and molliter manus imposuit (i.e. he gently placed his hand on another) in defence of his possession, without setting up his specific title, for his title (or interest) is not in issue;

- $\underline{U x} \boldsymbol{v}$ Tebbart $(\mathbf{1 6 9 3})^{338}$ An action for trespass for assault and battery. D came to P's house and continued there after $\mathrm{P}$ required him to leave. $\mathrm{P}$ commanded his wife to put $\mathrm{D}$ out of his house which she did (molliter manus imposuit). The plea was held to be justified. The court noted: 'to put hands upon any one against his will, is a battery'; 339

- Shingleton v Smith (1698) ${ }^{340}$ D beat and wounded a horse. The servant of the owner, in order to defend the horse, put his hands on $\mathrm{D}$ who then beat $\mathrm{P}$. It was held the replication in the pleadings was bad (because it did not allege the D had beaten the horse before P put his hands on the D).

\section{These cases confirmed the right of a person to defend their property.}

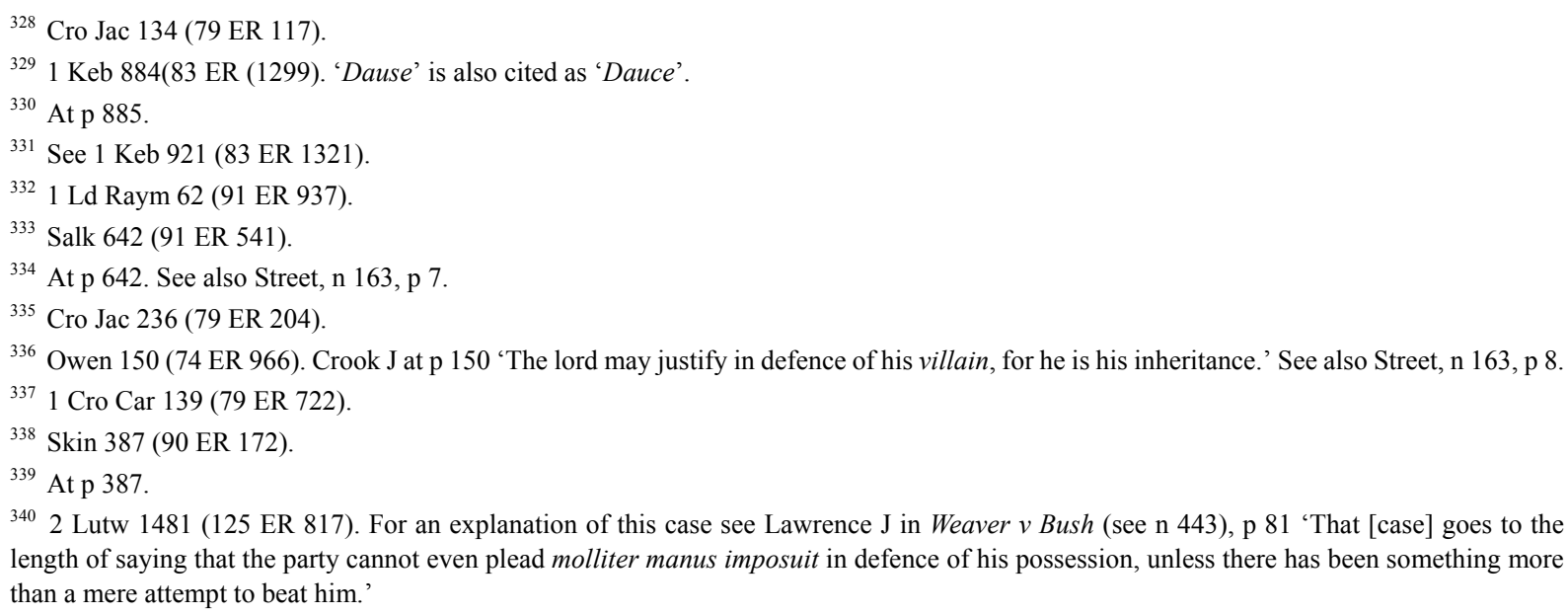




\section{(e) Legal Correction}

- The Wife of Cloborn v Her Husband (1629) ${ }^{341}$ A complaint by a wife against her husband in the spiritual court, who, it was alleged, had given her a box on the ear, spat in her face, whirled her about and called her a damned whore. The court held 'And certainly the matter alleged is cruelty; for spitting in her face is punishable by the Star Chamber. But if Mr Cloborn had pleaded a justification, and set forth a provocation to him by the wife, to give her reasonable castigation; then there would be some colour of a prohibition.';

- Manby v Scott (1639) ${ }^{342}$ The court noted that, if a man beat his wife, she could have him bound over for good behaviour by a JP ('Et pur ceo si baron batue sa feme il poit luy a son bone port devant un justice de peace.');

- Bleeke v Grove (1663) ${ }^{343}$ An action for trespass for assault, battery and wounding by a servant who had been beaten by his master for neglect; ${ }^{344}$

- $\quad \underline{\text { Keite }}$ (1696) $^{345}$ In this case, Holt CJ stated: 'if a master gives correction to his servant, it ought to be with a proper instrument, as a cudgel, etc. And then if by accident a blow gives death, this would be but manslaughter. The same law of a school-master. But a sword is not a proper instrument for correction.... 346

\section{These cases confirmed the right of parents etc. to administer correction. However, it had to be reasonable.}

\section{(f) Legal Justification}

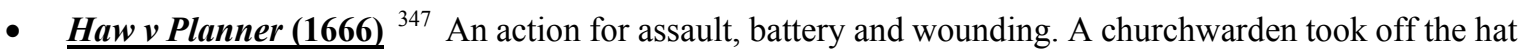
of another in church, when he refused to take it off. This was held a good justification, in order to prevent a breach of the peace in church;

- $\quad$ Truscott v Carpenter and Man (1697) ${ }^{348}$ The court held that: "where an express battery is laid it is not enough to justify the imprisonment upon legal process, which includes a battery; but the defendant ought to go on, and shew that he arrested the plaintiff, and the plaintiff offered to rescue himself, and so the defendant was compelled to beat him. For otherwise if it be not upon some such occasion, a man cannot justify a battery in an assault.'; ${ }^{449}$

- Lane v Degberg (1699) ${ }^{350}$ In this case Treby CJ indicated that D might justify even a mayhem, if done by him as an officer in the army on a person for disobeying orders;

- Genner v Sparks (1704) ${ }^{351}$ A bailiff having a warrant for D went to his house and told him that he had a warrant and had come to arrest him. He pronounced the word 'arrest' but did not touch him. D snatched up a pitchfork, kept the bailiff away and threatened to kill him if he approached closer. The court agreed that 'if the defendant were within reach of the bailiff when he pointed the pitchfork at him, he might have his action of assault against him; so if he had presented a gun at him at such a distance as the shot would reach him.' 352

\section{These cases considered the right of the requisite authorities to administer due legal punishment.}

\section{Hawkins (1716-21)}

The next major legal text of those times was that of Hawkins.

\footnotetext{
${ }^{341}$ Hetley 149 (124 ER 414).

${ }^{342} 1 \mathrm{Sid} 109$ at 116 (82 ER 1000)(Exchequer Chamber). The case concerned a wife who had separated from her husband, without his consent, for 12 years. She returned home and then ran up bills with a tradesman.

${ }^{343} 1 \mathrm{Sid} 176$ (82 ER 1040).

${ }^{344}$ The court referred to 1481.025 (see n 188). Also to W Rastell, Colleccion of Entries (1670 ed) p 613, pl 18 (schoolmaster and pupil)

${ }^{345} 1$ Ld Raym 139 (91 ER 989).

${ }^{346}$ At p 144. Also, '[if] it was immoderate correction, and the [servant] well might return the blows.'

347 Sid 301 (82 ER 1119).

${ }^{348} 1$ Ld Raym 229 (91 ER 1051).

${ }^{349}$ At p 232.

${ }^{350}$ Cited by Buller, n 37, p 19.

${ }^{351} 6 \operatorname{Mod} 173$ (87 ER 928).

${ }^{352}$ At $\mathrm{p} 174$.
} 
- In the first edition of his treatise on the Pleas of the Crown in 1716-21(a publication that was to continue until 1824) Hawkins considered 'several kinds of actual disturbances of the peace' including assault and battery;

- It may be noted that the wording in Hawkins on assault and battery changed remarkably little from the first edition of Hawkins in 1716-21 until the last edition of Hawkins in 1824 (the same as happened with Dalton with his work, see 13).

Changes (or the lack of) are mentioned in the footnotes.

\section{(a) Definition - Assault}

Hawkins stated: 'notwithstanding the many ancient opinions to the contrary, it seems agreed at this day, that no words whatsoever can amount to an assault. ${ }^{353}$ This statement refers to a change in the law since a case in 1353 (the threatening of a tax collector, see 9(a)) as well as Lambard (writing in 1581, see 10(a)) and Dalton (writing in 1619 , see 13(a)) were clearly of the opinion that a threat to beat someone up (for example), could be an assault 354 As to the definition of assault, Hawkins stated:

an assault is an attempt, or offer, with force and violence, to do a corporal hurt to another. ${ }^{355}$

It is asserted the word 'offer' here is used as a synonym for an 'attempt' and not as a separate concept. ${ }^{356}$ Hawkins gave some examples of assault, a person:

- striking at another with (or without) a weapon; or

- presenting a gun at such a distance to which the gun will carry; ${ }^{357}$ or

- pointing a pitch fork at another, standing within reach of it; ${ }^{358}$ or

- holding up a fist at another; or

- any other like act done in an angry (or threatening) manner. ${ }^{359}$

Thus, Hawkins restricted 'assault' to an 'attempt' to do a battery. ${ }^{360}$

- It was unfortunate that Hawkins referred to 'corporal hurt' in his definition of assault and yet to 'injury' in his definition of battery, since a reference to physical injury applies to both and so the same words can be used;

- Hawkins asserted that 'no words' (including threats) could amount to an assault - even though this was contrary to any 'ancient opinions' to the contrary, including those of Lambard and Dalton. However, Hawkins appears to cite insufficient authority for his assertion; ${ }^{361}$

- Hawkins referred to 'force and violence' in his definition of assault and yet to 'in an angry, or revengeful, or rude, or insolent manner' in his definition of battery. ${ }^{362}$ Neither are required since battery can relate to the slightest touch (and assault, a threat to impose the same). It is likely that Hawkins took this wording from Holt CJ in Cole v Turner (1704)(see 14(b)) without considering the matter further. This was unfortunate since Hawkins' definition was endlessly cited thereafter;

\footnotetext{
${ }^{353}$ Hawkins, $\mathrm{n} 34$, vol $1 \mathrm{p} 134$. This Hawkins linked to the fact that a recognizance for surety of the peace was not forfeited by words alone, At p 130 'it seems that it shall not be forfeited by bare words of heat and choler, as the calling a man knave, teller of lies, rascal, or drunkard, for tho' such words may provoke a cholerick [i.e. irascible] man to break the peace, yet they do not directly challenge him to it, nor does it appear that the speaker designed to carry his resentment any further; and it hath been said, that even a recognizance for the good behavior, shall not be forfeited for such words, from whence it follows, a fortiori, that the recognizance for the peace shall not.'

${ }^{354}$ Bracton was of a similar opinion (see $\mathrm{n}$ 145), following Roman law.

${ }^{355}$ Hawkins, n 34, vol 1, p 133. Hawkins cited Pulton.

${ }^{356}$ See n 260

${ }^{357}$ Hawkins, n 34, vol 1, p 133 referred to Genner v Sparks (see 14) and to Rolle, n 21, vol 2, pl 545, 10, 11 (Rolle referred to 1348.268 ass (see n 161).

${ }^{358}$ Hawkins referred to Genner $v$ Sparks (see 14).

${ }^{359}$ Hawkins, n 34, vol 1, pp 133-4. Hawkins referred, in support of this definition, to Lambard and Pulton as well as to various Yearbook cases, viz. (a) 40 Edw 3 40a (see Seipp no 1366.101, see n 162); (b) 42 Edw 3 7a (see Seipp no 1368.025, see n 163); (c) 45 Edw 3 24b, 25a; (see Seipp no 1371.058, see n 164) (d) 22 Ass 60 (see Seipp no 1348.268ass, see n 161); (e) 22 Ass pl 11 (see Seipp no 1353.136 ass, n 167). Hawkins also referred to Rolle, n 21 vol 2, $545 \mathrm{pl} 1-8$ as well as to Dause v Luce (see 14),

${ }^{360}$ The reference to 'offer' likely derived from Cowell. See also n 260.

${ }^{361}$ In the side note, Hawkins cited only 1 Keb 921 (Dause v Luce, see 14) and 6 Mod 173, 174 (Genner v Sparks, see 14, the word 'arrest' was not used as a threat). However, in neither of these cases was such a proposition made.

${ }^{362}$ The words 'force' and 'violence' For these words see Cowell (see 11(f)) and Holt CJ in Cole v Turner (see 14(b)).
} 
- Assault was an offence in a private place. As Hawkins noted, when in a public place, the offence was affray. ${ }^{363}$

It would have been appropriate (and succinct) for Hawkins (in hindsight) to have defined an assault as a threat to commit a battery - since an assault is not an attempted battery (a person might, for example, raise a weapon but not intend to strike). However, given the existence of a separate common law offence in respect of menaces (threats)(see 12) this may have been the reason why Hawkins did not describe an assault as a 'threat' to batter someone.

\section{(b) Definition - Battery}

Hawkins stated that a battery comprised:

any injury whatsoever, be it never so small, being actually done to the person of a man, in an angry, or revengeful, or rude, or insolent manner. ${ }^{364}$

Hawkins gave as examples, a person:

- spitting in another's face; ${ }^{365}$ or

- in any way touching another in anger; ${ }^{366}$ or

- violently jostling another out of the way.

\section{(c) Defences}

Hawkins referred to his prior discussion on the surety of the peace ${ }^{367}$ where he had stated: 'there are some actual assaults on the person of another, which do not amount to a forfeiture of such a recognizance'. He provided the following examples:

- $\quad$ Self Defence. A man beats, wounds or maims one who assaults him - especially, if it appears he did all he could to avoid fighting before he gave the wound. ${ }^{368}$ A man threatens to kill one who puts him in fear of death in a place where he cannot safely fly from (i.e. escape); ${ }^{369}$

- Defending Others. A man forces a sword from one who offers to kill another therewith. ${ }^{370}$ A man gently lays his hands on another to stop him from inciting a dog against a third person. ${ }^{371}$ A man beats, wounds or maims one who assaults him, his wife, parent, child ${ }^{372}$ or master $^{373}$ - especially, if it appears he did all he could to avoid fighting before he gave the wound. A man fights with (or beats) someone who attempts to kill a stranger. ${ }^{374}$ A person imprisons those whom he sees fighting, until the 'heat' is over; ${ }^{375}$

\footnotetext{
${ }^{363}$ Hawkins, n 34, vol 1, p 134 'it is said, that the word affray is derived from the French word effrayer, to terrify, and that in a legal sense it is taken for a public offence, to the terror of the people, from whence it seems clearly to follow, that there may be an assault which will not amount to an affray, as where it happens in a private place, out of the hearing of seeing of any, except the parties concerned; as in which case it cannot be to the terror of the people...'

${ }^{364}$ Ibid.

${ }^{365}$ See Cotesworth (see 14).

${ }^{366}$ See Cole v Turner (see 14).

${ }^{367}$ Hawkins, n 34, vol 1, p 134 'this is so fully set forth already in the chapter of surety of the peace, that there seems to be no need of any further consideration thereof in this place...'.

${ }^{368}$ Ibid, p 130. Hawkins cited, inter alia: (a) 8 Hen 4 8a-b (Seipp no 1400.041, see n 172); (b) 9 Edw 4, 48 (Seipp no 1470.004, see n 177) and (c) 12 Edw 4 6a (Seipp no 1472.023, see n 178). Also, Coke (see n 310) and Rolle, n 21, vol 2, p 547. Hawkins also cited Dause v Luce (see 14) and $R v$ Mawgridge (1707) Kely 119 (84 ER 1107) at $\mathrm{p} 128$ 'It is not reasonable for any man that is dangerously assaulted, and when he perceives his life in danger from his adversary, but to have liberty for the security of his own life, to pursue him that maliciously assaulted him; for he that hath manifested that he hath malice against another is not fit to be treated with a dangerous weapon in his hand.'

${ }^{369}$ Hawkins cited: (a) 33 Hen 6 18b (Seipp no 1455.037, see n 175) and (b) 10 Edw 46 (in 1470, see n 185).

${ }^{370}$ Hawkins cited Marler $v$ Ayliffe \& Eylett (see 14) and Rolle, n 21, vol 2, p 546.

${ }^{371}$ Hawkins cited Rolle, n 21, vol 2, p 546.

${ }^{372}$ See Rolle, n 21, vol 2, p 546 (citing Walter v Jones (1634)(inciting a dog at a child)).

${ }^{373}$ Hawkins cited: (a) 35 Hen 6 50, 51 ( see Seipp no 1457.015, see n 176); (b) 19 Hen 6 31, 66 (see Seipp no 1440.077, see n 183) and (c) 12 Edw 46 (see Seipp no 1472.023, see n 178). Also, Dalton, Crompton (see n 27) and Rolle, n 21, vol 2, p 546 (case in 1634).

${ }^{374}$ Hawkins cited 12 Hen 8 2b (12 Hen 8 pl 3 fo SS, vol 119, pp 14-18, Case of Fyloll v Assheleygh (1520)(trespass for beating a servant and carrying away a bloodhound) per Broke J, p 15 'if a lord beats his villain, or a husband his wife, or someone beats an outlaw, traitor or heathen: these people shall have no action, because they are unable to sue.).'

${ }^{375}$ Ibid, p 131. Hawkins cited Rolle, n 21, vol 2, p 559.
} 
- Defending Goods \& Land. A man beats one (without wounding him, or throwing at him a dangerous weapon) who wrongfully endeavours, with violence, to dis-possess him of his land or goods ${ }^{376}$ and will not desist when hands are gently laid on him;

- Lawful Correction. A parent, in a reasonable manner, chastises his child ${ }^{377}$ a husband his wife, ${ }^{378}$ a schoolmaster his scholar ${ }^{379}$ a master his servant, ${ }^{380}$ a gaoler his prisoner. ${ }^{381}$ Or a person confines a friend who is mad and binds and beats him in such a manner as is proper in such circumstances; ${ }^{382}$

- Legal Justification. An officer with a warrant beats (or wounds) a person who will not suffer himself to be arrested. ${ }^{383}$ And, 'it is said to be no battery to lay one's hand gently on another whom an officer has a warrant to arrest, and to tell the officer that this is the man he wants.'; ${ }^{384}$

- Consent. Hawkins stated: 'it seems to be the better opinion, that a man is in no danger of such a forfeiture from any hurt done to another, by playing at cudgels, or such like sport, by consent, because the intent of the parties seems no way unlawful, but rather commendable, and tending mutually to promote activity and courage; yet it is said, that he who wounds another in fighting with naked swords, does in strictness forfeit such a recognizance, because no consent can make so dangerous a diversion lawful. ${ }^{385}$

Hawkins also make it clear that negligence and accidental behaviour (misadventure) resulting in an assault or battery were not criminal. Thus, he stated:

it seemeth, that a man shall not forfeit such recognizance, by a hurt done to another merely through negligence, or mischance; as where one soldier hurts another by discharging a gun in exercise, without sufficient caution; for notwithstanding such person must, in a civil action, give the other satisfaction for the damage occasioned by his want of care, yet he seems not to have offended against the purport of such recognizance, unless he be guilty of some wilful breach of the peace. ${ }^{386}$

In conclusion, Hawkins followed Pulton and Dalton. However, he excluded words (threats) from assault and incorrectly - indicated that battery must be done in an angry, revengeful, rude or insolent manner (which expression was later summarised in the word 'hostile'). Hawkins expressly noted that assaults and batteries arising from accident or negligence were not criminally liable.

\section{Summary of the Law from 1290-1721}

The law of assault and battery from 1290 (after Britton wrote) until the first edition of Hawkins is not at all complex. Indeed, it is remarkable for its consistency:

- $\quad$ Assault \& Battery. The caselaw in the Yearbooks suggests that assault was recognised as a separate offence by the mid- $14^{\text {th }}$ century (see 9(a));

- Definitions of Assault \& Battery. The most recurrent definitions were those of: Cowell (in 1607), Dalton (in 1619) and Hawkins (in 1716-21).Thus,

\footnotetext{
${ }^{376}$ Hawkins cited: (a) 3 Hen 469 (Seipp no 1402.003, see n 181); (b) 19 Hen 631 (case in 1440, Seipp no 1440.077, see n 183 ); (c) 10 Edw 4 $6 \mathrm{~b}$ (in 1470, see n 185)); ((d) $11 \mathrm{Edw} 428 \mathrm{~b}$ (Seipp no 1471.005 (trespass for breaking close)). Hawkins also cited a case in 1506, see n 276 as well as Shingleton $v$ Smith (see 14) and Seaman v Cuppledick's Case (see 14). Hawkins also cited Coke (see $\mathrm{n} 310$ ) as well Lee v Atkinson \& Brooks (see 14), Skevill v Avery (see 14) and Dodwell v Burford (see 14). Hawkins also cited Rolle, n 21, vol 2, p 547-9 as well as Pulton and Dalton.

${ }^{377}$ Hawkins cited Dalton and Crompton (see n 27).

${ }^{378}$ Hawkins cited (contra) Manby v Scott (see 14) and The Wife of Cloborn v Her Husband (see 14). Hawkins also cited Crompton (see $\left.\mathrm{n} 27\right)$ and Fitzherbert, $\mathrm{n} 220$ (writ de securitate pacis).

${ }^{379}$ Hawkins cited Bleeke v Grove (see 14). Also, 21 Edw 46 (Seipp no 1481.025, see n 188).

${ }^{380}$ Hawkins cited 33 Hen 625 (Seipp no 1460.010, see n 186) and Bleeke v Grove (see 14). See also Rastell, n 344.

${ }^{381}$ Hawkins cited Dalton.

${ }^{382}$ Hawkins cited: (a) 22 Ass 56 (Seipp no 1348.264ass, n 187) and (b) 22 Edw 45 (Seipp no 1483.010, see n 191). Also, Rolle, n 21, vol 2, p 546. See also an Act of 12 Anne sess 2 c 23 s 22 (1712) which provided for JP's, by warrant to constables etc., to have lunatics and persons furiously mad locked up and, if necessary, chained).

${ }^{383}$ Hawkins cited (a) 2 Edw 46 (Seipp no 1481.025, see n 188); (b) 21 Hen 739 (Seipp no 1505.051, see n 195).

${ }^{384}$ Hawkins, n 34, vol 1, p 134 cited Cole v Turner (see 14), Cotesworth (see 14) and Rolle, n 21, vol 2, p 546, pl 1 \& 2 (which refers to cases in 1614 \& 1615).

${ }^{385}$ Hawkins, n 34, vol 1, p 131. Hawkins cited Dalton and a case in 1496 (Seipp no 1496.029, see n 196). The wording in the text was the same in the 1824 version.

${ }^{386}$ Hawkins cited Weaver $v$ Ward (see 14) and Rolle, n 21, vol 2, 548 (citing Weaver $v$ Ward). The wording in the text was the same in the 1824 version.
} 
Cowell - (assault) a 'violent kind of injury offered to a man's person' even though it 'did not always imply a blow or striking'. (battery) 'a violent striking or beating any man';

Dalton - (assault) 'when one unlawfully sets upon the person of another, offering to beat him, although he beats him not, or striking at him, though he strikes him not.' (battery) 'the wounding or beating another';

Hawkins - (assault) 'an attempt, or offer, with force and violence, to do a corporal hurt to another.' (battery) 'any injury whatsoever...actually done to the person of a man, in an angry or revengeful or rude or insolent manner.'

There are difficulties with all these definitions in that there is insufficient detail as to the actus reus and mens rea of them - such that the definitions are too wide in scope, in the criminal context. Cowell, Dalton and Hakwins captured one of the elements of battery - physically injuring another. However, they failed to note that it should be unlawful and that violence was not necessary (since it could effected by the lightest touch). In particular, Hawkins' reference to battery needing to be done in a 'an angry or revengeful or rude or insolent manner', although incorrect, was endlessly repeated by later writers.

After Hawkins first wrote in 1716-21, his definitions of assault and battery - as well as his description of the same and the defences - became the standard ones cited and this continued even after the last edition of this work in 1824. The problem with this was that endless repetition was not conducive to later writers analysing the essential elements of these offences - not until the $20^{\text {th }}$ century.

\section{Burn (1755), Finch (1759), Blackstone (1768-9) \& Buller (1788)}

When considering legal texts in the 18th century vis-à-vis assault and battery, Hawkins was the dominant text and other legal writers usually cited him.

\section{(a) Burn (1755) \& Finch (1759)}

Burn, in the first edition of The Justice of the Peace and Parish Officer (1755) - a popular text that was to last until 1869 (see 24) - cited Hawkins for all his propositions. Thus, the definitions by Burn of assault ${ }^{387}$ and battery 388 closely followed those of Hawkins. Following Hawkins, Burn also cited instances where an assault might be justified. viz.

- self-defence; ${ }^{389}$

- defence of certain others; ${ }^{390}$

- defence of a man's land and possessions; ${ }^{391}$

- lawful correction; ${ }^{392}$

- legal justification. ${ }^{393}$

\footnotetext{
${ }^{387}$ Burn, n 35, vol 1, p 75. 'Assault, assultus, from the French assayler, is an attempt or offer, with force and violence, to do a corporal hurt to another, as by striking at him with or without a weapon; or presenting a gun at him, at such a distance to which the gun will carry; or pointing a pitch-fork at him, standing within the reach of it, or by holding up one's fist at him; or by any other such like act, done in an angry, threatening manner. And from hence it clearly follows, that one charged with an assault and battery, may be found guilty of the assault, and yet acquitted of the battery... But every battery includes an assault; therefore on an indictment of assault and battery, in which the assault is laid, if the D be found guilty of the battery, it is sufficient.'

${ }^{388}$ Ibid, p 76. 'Battery (from the French batre, to strike, or the Saxon batte, a club) seems to be, when any injury whatsoever, be it never so small, is actually done to the person of a man, in an angry, or revengeful, or rude, or insolent manner, as by spitting in his face, or any way touching him in anger, or violently jostling him out of the way, and the like.'

${ }^{389} \mathrm{Ibid}$, 'A person may justify an assault, in defence of his person, or of his wife, or master, or parent, or child within age, and even a wounding may be justified in defence of his person, but not of his possessions.' Burn cited 3 Salk 46 (91 ER 683) which stated, inter alia, 'A master may justify the beating his apprentice, servant, scholar etc. if the beating is in the nature of correction only, and with a proper instrument, otherwise immoderate castigavit [correction] is a good reply.' It cited Keite (see 14). See also Burn, vol 1, p 53 (master allowed by law with moderation to chastise his apprentice).

${ }^{390}$ Ibid.

${ }^{391}$ Ibid, 'a person may justify an assault and battery of another, who doth menace or assault him and attempt to beat him from his lawful watercourse or highway.' Burn cited Pulton. Ibid, p 76 'if a person comes into my house, and will not go out, I may justify laying hold of him, and turning him out.'

${ }^{392}$ Ibid 'if an officer having a lawful warrant lay hands on another to arrest him, or if a parent in a reasonable manner chastise his child, a master his servant, a schoolmaster his scholar, a gaoler his prisoner, and even a husband his wife, as some say, or if one confine a friend who is mad, and bind and beat him in such a manner as is proper in his circumstances, or if a man force a sword from one who offers to kill another therewith; in all these cases, and such like, it is justifiable.' Burn cited Hawkins.

393 Ibid.
} 
Finch, A Description of the Common Laws of England (1759) ${ }^{394}$ provided definitions of 'assault' ${ }^{395}$ and 'battery'. 396

\section{(b) Blackstone (1768) - Definitions}

Blackstone (writing in 1768), in his Commentaries on the Laws of England, said virtually nothing on assault and battery in the criminal context. ${ }^{397}$ Instead, his definitions were delivered in the civil context. Thus, in the third volume of his work (published in 1768) (398 $^{39}$ he stated, in respect of injuries affecting the limbs and body:

assault; which is an attempt or offer to beat another, without touching him: as if one lifts up his cane, or his fist, in a threatening manner at another; or strikes at him, but misses him; this is an assault, insultus, which Finch describes to be 'an unlawful setting upon one's person.' 399

battery; which is the unlawful beating of another. The least touching of another's person wilfully, or in anger, is a battery; for the law cannot draw the line between different degrees of violence, and therefore totally prohibits the first and lowest stage of it: every man's person being sacred, and no other having the right to meddle with it, in any the slightest manner. And therefore upon a similar principle the Cornelian law de injuriis prohibited pulsation as well as verberation; distinguishing verberation, which was accompanied with pain, from pulsation which was attended with none. ${ }^{400}$

\section{(c) Blackstone (1768) - Defences}

As to defences, Blackstone stated:

But battery is, in some cases, justifiable or lawful; as where one who hath authority, a parent or master, gives moderate correction to his child, his scholar or his apprentice. So also on the principle of self-defence: for if one strikes me first, or even only assaults me, I may strike in my own defence; and, if sued for it, may plead son assault demesne, or that it was the plaintiff's own original assault that occasioned it. So likewise in defence of my goods or possession, if a man endeavours to deprive me of them, I may justify laying hands upon him to prevent him; and in case he persists with violence, I may proceed to beat him away. ${ }^{401}$

Thus too in the exercise of an office, as that of a churchwarden or beadle, a man may lay hands upon another to turn him out of church, and prevent his disturbing the congregation. ${ }^{402}$ And, if sued for this or the like battery, he may set forth the whole case, and plead that he laid hands upon him gently, molliter manus imposuit, for this purpose. On account of these causes of justification, battery is defined to be the unlawful beating of another; for which the remedy is, as for assault, by action of trespass vi et armis:

\footnotetext{
394 The first edition of this work was in 1613, the last in 1759. Blackstone often cited him.

${ }^{395}$ H Finch, A Description of the Common Laws of England (London, 1759), p 68 'Assault is when one unlawfully sets upon the person of any man; as if he offer to beat him, tho' he do not beat him in deed; if he strike at him with a hatchet, or the like, tho' he do not hit him.' The first edition of Finch (Nomotechnia, 1613) is usually known by the title of the $2^{\text {nd }}$ edition (in 1627), Law, or a Discourse thereof. It stated, pp 202-3 'Assault is an unlawful setting upon one's person... [citing a case in 1366, see n 162]... Batterie is the wrongful beating of one.'

396 Ibid, p 67 'Battery is the wrongful beating of one: but if a man will take my goods, I may lay my hands upon him, and hinder him, and if he will not leave them, I may beat him rather than he shall have them.' Cf. p 68 'Menaces are threatening words to beat any one, for the like, for the fear of which he loseth his business; for menace alone, without other loss, does not make the trespass, but both together.'

396 Ibid.

397 Blackstone, n 36, vol 4, p 145.

${ }^{398}$ Ibid, vol 3, p 119. He called assault and battery ‘in a public light [i.e. under the criminal law] ... a breach of the king's peace, an affront to his government, and a damage done to his subjects.' Also, 'assault, battery, and mayhem, an indictment may be brought as well as an action; and frequently both are accordingly prosecuted: the one at the suit of the crown for the crime against the public; the other at the suit of the party injured, to make him a reparation in damages.'

399 See Finch, n 395. Blackstone continued 'This also is an inchoate violence, amounting considerably higher than bare threats; and therefore, though no actual suffering is proved, yet the party injured may have redress by action of trespass vi et armis; wherein he shall recover damages as a compensation for the injury.'

${ }^{400}$ Blackstone cited Justinian's Digest (see n 59) 47.10 .5 (Contumelies and Defamatory Writings) Ulpian, Edict, book 56 'the lex Cornelia gives an action on three grounds: that a person was beaten or was thrashed or that his house was entered by force. It appears that every physical affront is covered by the lex Cornelia. Between beating and thrashing there is, as Ofilius writes, this difference: to thrash is to hit with the infliction of pain, to beat is without it.' Ulpian (c. 170-223) was Roman jurist whose works were often cited. Ofilius $\left(1^{\text {st }}\right.$ c BC) was also a Roman jurist and a friend of Cicero.

401 Blackstone cited Finch.

${ }^{402}$ Blackstone cited Haw v Planner (see 14).
} 
wherein the jury will give adequate damages. ${ }^{403}$

In conclusion, Blackstone's definition of battery was a useful advance - in that it indicted that the battery must be unlawful and that the least touching was sufficient (i.e. violence or hostility was unnecessary).

\section{Cases: 18th Century}

The following cases were often cited in relation to assault and battery:

- Green v Goddard (1702) ${ }^{404}$ A battery cannot be justified on account of breaking his close, in law, without a request to depart. However, it is otherwise, if a person come to my close vi et armis, for that is but returning violence with violence;

- Underwood v Hewson (1724) ${ }^{405} \mathrm{D}$ was uncocking a gun. P was standing close to him to see it. It went off and wounded the latter. It was held that P could maintain an action an action for trespass, for accidental hurt;

- Gill (1731) ${ }^{406}$ An indictment against D for throwing down a skin in a man's yard which was a public way. The skin was blown away, damaging another's eye. D was held not criminally liable since it was accidental;

- Boulter v Clerk.(1747) ${ }^{407}$ In an action of assault and battery (fighting with fists by consent with no money involved), since fighting was unlawful, consent to fight was no bar to an action for assault and battery;

- Short v Lovejoy (1752) ${ }^{408}$ Buller stated as to this case: 'if a man wantonly [i.e. intentionally] do an act by which another man is hurt; as by pushing a drunken man, he will be answerable in an action of assault and battery, but if he intend doing a right act, as to assist such drunken man, or prevent him from going along the street without help, and in so doing, an hurt do ensure, [i.e. if it is accidental] he will not be answerable.'

- Scott $\boldsymbol{v}$ Shepherd (1773) ${ }^{409}$ An action for trespass and assault for throwing, casting and tossing a lighted squib at the P, striking him on the face, with the result that he lost the sight of an eye. Nares J stated: 'The intermediate acts ... will not purge the original tort in the defendant. But he who does the first wrong is answerable for all the consequential damages. ${ }^{410}$

\section{Buller (1788) \& East (1803)}

Buller, in his Introduction to the Law relative to Trials at Nisi Prius (1788), considered assault and battery. He stated:

an assault is an attempt or offer by force or violence, to do a corporal hurt to another, as by pointing a pitchfork at him, when standing within reach; presenting a gun at him; drawing a sword, and waiving it

\footnotetext{
${ }^{403}$ Blackstone, n 36, vol 3, pp 120-1. Blackstone then refers to mayhem '4. By mayhem or wounding; which is an injury still more atrocious, and consists in violently depriving another of the use of a member proper for his defence in fight. This is a battery, attended with this aggravating circumstance, that thereby the party is forever disabled from making so good a defence against future external injuries, as he otherwise might have done. Among these defensive members are reckoned not only arms and legs, but a finger, an eye, and a fore-tooth, and also some others. But the loss of one of the jaw-teeth, the ear, or the nose, is no mayhem at common law; as they can be of no use in fighting. The same remedial action of trespass vi et armis lies also to receive damages for this injury; an injury, which (when wilful) no motive can justify, but necessary self-preservation...'.

4042 Salk 641 (91 ER 540).

${ }^{405} 1 \mathrm{Str} 596$ (93 ER 722).

4061 Stra 190 (93 ER 466).

${ }^{407}$ Buller, n 37, p 15. Ibid, pp 16-7 stated 'In an action of assault and battery, Mr Serjeant Howard would have proved that the plaintiff and the defendant fought by consent....but Parker Chief Baron denied it, and said, the fighting being unlawful, the consent of the plaintiff to fight (if proved) would be no bar to his action; and cited Winch 49. 2 Lev 174 [i.e. Allen v Rescous] and Webb and Bishop of Gloucester Lent Assizes 1731, before the Lord Ch Baron Reynolds, where in an action for five guineas on a boxing match, the judge held it an illegal consideration, and the plaintiff was nonsuited. Comb 218 Matthew v Ollerton, where it was said, that if a man licence another to beat him, such licence is void because it is against the peace; and thereupon the plaintiff had a verdict, and 30s damages.' Thus, Buller referred to Allen $v$ Rescous (1676) 2 Lev 174 (80 ER 505)(a contract to beat another up was illegal and void) and to Matthew v Ollerton (1693) Com 218 (90 ER 438)(the court stated 'licence to beat one is void, because 'tis against the peace.').

408 Ibid, p 16.

4092 W Black 289 (96 ER 525). See also p 893 'That the natural and probable consequence of the act done by the defendant was injury to somebody, and therefore the act was illegal at common law.' Nares also gave as an example of battery setting a mad ox loose in a crowd made the person doing so liable for battery for any contact made with a person. See also Trindade, n 319, p 217.

${ }^{410}$ At p 526.
} 
in a menacing manner etc... ${ }^{411}$

a battery, which always includes an assault, is the actual doing an injury, be it ever so small, in an angry, or revengeful, or rude, or insolent manner; as by spitting in his face, or violently jostling him out of the way. But if two by consent play at cudgels, and one hurt the other, it is no battery; ${ }^{412}$ so if one soldier hurt another in exercise; but, if he plead it, he must set forth the circumstances, so as to make it appear to the court, that it was inevitable, and that he committed no negligence to give occasion to the hurt: for it is not enough to say, that he did it casualiter et per infortunium, contra voluntatem suam, for no man shall be excused a trespass, unless it may be justified entirely without his default [i.e. wholly accidental]; ${ }^{413}$ and therefore it has been holden, that an action lay where the plaintiff standing by to see the defendant uncock his gun, was accidentally wounded. ${ }^{414}$

Buller then considered justification ${ }^{415}$ which might be pre-emptive ${ }^{416}$ but must be reasonable. ${ }^{417}$ Finally, following Hawkins, he stated:

There are many other matters which may be pleaded in justification: as if an officer having a warrant against one who will not suffer himself to be arrested, beat or wound him in the attempt to take him; so if a parent in a reasonable manner chastise his child, or a master his servant, or a schoolmaster his scholar, or a gaoler his prisoner; or if I beat one who wrongfully endeavours to dispossess me of my lands and goods, or who assaults my wife, parent, child or master... 418

In conclusion, Burn and Buller added little to Hawkins. However, Blackstone (usefully) noted that a battery must be unlawful and that the least touching was sufficient (i.e. it did not need to be violent or hostile). He also defined assault as an attempt (or offer) to beat another.

\section{East (1803)}

East, in his Treatise of the Pleas of the Crown (in 1803) considered assault and battery. However, he did so only briefly since, citing Buller, he noted 'they are so fully discussed in other books treating of the civil remedy for such injuries to the party grieved. ${ }^{419}$ East stated:

An assault is any attempt or offer with force and violence to do a corporal hurt to another, whether from malice or wantonness, as by striking at him, or even by holding up one's fist at him in a threatening or insulting manner, or with such other circumstances as denote at the time an intention, coupled with a present ability of using actual violence against his person; as by pointing a weapon at him within the reach of it. ${ }^{420}$

Where the injury is actually inflicted, it amounts to a battery (which includes an assault) and this, however small it may be; as by spitting in a man's face, or any way touching him in anger without any lawful occasion.

But if the occasion were merely accidental and undersigned, or if it were lawful, and the party used no more force than was reasonably necessary to accomplish the purpose, as to defend himself against a prior assault, or to arrest the other, or make him desist from some wrongful act or endeavour, or the like; it is no assault or battery in the law, and the party may justify the force; and any matter in justification

\footnotetext{
${ }^{411}$ Buller, $\mathrm{n} 37, \mathrm{p} 15$. Buller cited $R$ v Ingram \& Ux (see 14). See also Bacon (in 1798), $\mathrm{n} 25$, vol 1, $\mathrm{p} 242$ 'An assault is an attempt or offer with force and violence to do a corporal hurt to another.' (same in the last edition in 1832).

${ }^{412}$ Buller cited Weaver $v$ Ward (see $\mathrm{n}$ 14) and Boulter v Clerk.( see 18) See also Bacon, $\mathrm{n} 25$, vol 1, p 243 'Any injury whatsoever, be it ever so small, being actually done to the person of a man, in an angry or revengeful, or rude or insolent manner, as by spitting in his face, or any way touching him in anger, or violently jostling him out of the way, are batteries in the eyes of the law.' (same in the last edition in 1832).

${ }^{413}$ Buller, n 37, p 16, Buller cited Short v Lovejoy (see 18) and Gibbons v Pepper (see 14). See also Baker, n 160, p 405.

${ }^{414}$ Ibid, p 16. Buller cited Underwood \& Hewson (see 18).

${ }^{415}$ Ibid, p 17 'Justification is an insisting upon something that made it lawful for him to do the fact laid to his charge...The most general matter of justification is, that the $P$ made the first assault.'

${ }^{416}$ Ibid, p 18 'If the defendant prove that the plaintiff first lifted up his staff, and offered to strike him, it is sufficient assault to justify his striking the plaintiff, and he need not stay till the plaintiff has actually struck him.'

${ }^{417}$ Ibid, 'every assault will not justify a battery; but it is a matter of evidence whether the assault was proportionate to the battery.' Buller cited Cockcroft $v$ Smith (see 14) and Dause v Lucy (see 14).

${ }^{418}$ Ibid, p18. Among other cases Buller cited Green v Goddard (see 14) and Lane v Degberg (see 14). See also Bacon (in 1798), n 25, vol 1, pp 244-5 (defences. Bacon cited Hawkins).

${ }^{419}$ East, n 38 p 406.

${ }^{420}$ East cited Hawkins and Buller.
} 
or excuse, such as son assault demesne, may upon an indictment be given in evidence under the general issue: and the defendant who is charged with an assault and battery, may be found guilty of the one and acquitted of the other. But son assault demesne is no excuse, if the retaliation by the defendant were excessive, and bore no proportion to the necessity, or the provocation received. ${ }^{421}$

East defined an assault: as 'an assault is any attempt or offer with force and violence to do a corporal hurt to another, whether from malice or wantonness.' The reference to malice and wantonness (wilfulness) is better expressed by reference to 'intent. ${ }^{, 422}$ Thus, East clarified that:

- No crime was committed if it were 'accidental';

- $\quad$ Self-defence must be proportionate;

- 'The present ability of using actual violence' was required for an assault. A future threat was insufficient; it had to be immediate.

In conclusion, East referred to the need for the assault or battery to be immediate (and not future), a criterion followed by later authors.

\section{Russell (1819)}

Russell, in the first edition of his Crimes and Misdemeanors (1819), a text which continued until 1964, ${ }^{423}$ considered the law on assault and battery under the heading of 'common and aggravated assaults.'

\section{(a) Definition - Assault}

Russell stated:

An assault is an attempt or offer, with force and violence, to do a corporal hurt to another; as by striking at another with a stick or other weapon, or without a weapon, though the party striking misses his aim. So drawing a sword or bayonet, or even holding up a fist in a menacing manner, throwing a bottle or glass with intent to wound or strike, presenting a gun at a person who is within the distance to which the gun will carry, pointing a pitchfork at a person who is within reach, or any other similar act, accompanied with such circumstances as denote at the time an intention, coupled with a present ability; of using actual violence against a person of another, will amount to an assault. ${ }^{424}$ (italics supplied)

In providing such a definition, Russell referred to previous legal writers. ${ }^{425}$ The essence of his definition of assault was: 'an attempt or offer, with force and violence, to do a corporal hurt to another' coupled with 'an intention, coupled with a present ability, of using actual violence'.

\section{(b) Definition - Battery}

Russell stated:

A battery is more than an attempt to do a corporal hurt to another: but any injury whatsoever, be it ever so small, being actually done to the person of a man, in an angry or revengeful, or rude, or insolent manner, such as spitting in his face, or in any way touching him in anger, or violently jostling him out of the way, is a battery in the eye of the law ${ }^{426}$....It should be observed that every battery includes an assault. ${ }^{427}$

The injury need not be effected directly by the hand of the party. Thus there may be an assault by encouraging a dog to bite; by riding over a person with a horse; or by wilfully and violently driving a cart, etc. against the carriage of another person, and thereby causing bodily injury to the persons travelling in

\footnotetext{
${ }^{421}$ Ibid. East then considered various statutory assaults (all of which have now been repealed), viz. assaults: (a) on privy counsellors; (b) MP's; (c) clergymen; (d) revenue officers; (e) in the king's palace; (f) in Westminster Hall (common law); (g) in churches and churchyards; (h) with intent to murder; (i) with intent to rob; (j) with intent to spoil clothes; (k) on persons wrecked; (l) on master woolcombers; (m) on account of gaming; (n) with intent to obstruct the free passage of grain.

${ }^{422}$ See Williams, 28(c).

${ }^{423}$ The last edition was edited by JWC Turner (see 29).

${ }^{424}$ Russell, n 38, vol 1, p 862.

${ }^{425}$ viz. Hawkins, Bacon, Burn, East, Buller, Selwyn and Blackstone. Russell also noted, p 862, that words did not make an assault. 'But it appears to be now quite settled, though many ancient opinions were to the contrary, that no words whatsoever, be they ever so provoking, can amount to an assault.' Russell cited Hawkins and Bacon.

${ }^{426}$ Russell cited Bacon and Hawkins. He continued, p 863 'For the law cannot draw the line between different degrees of violence, and, therefore, totally prohibits the first and lowest stage of it; every man's person being sacred, and no other having a right to meddle with it in any the slightest manner.' Russell cited Blackstone.

${ }^{427}$ Russell cited Termes de la Ley (definition of battery)(see n 257), Hawkins and Bacon.
} 
it. ${ }^{428}$ And it seems that it is not necessary that the assault should be immediate; as where a defendant threw a lighted squib into a market place, which, being tossed from hand to hand by different persons, at last hit the defendant in the face, and put out his eye, it was adjudged that this was actionable as an assault and battery. ${ }^{429}$ And the same has been holden where a person pushed a drunken man against another; and thereby hurt him: $:{ }^{430}$ but if such person intended doing a right act, as to assist the drunken man, or to prevent him from going along the street without help, and in so doing a hurt ensued, he would not be answerable. [i.e. no liability if accidental]

\section{(c) No Assault or Battery - Accident}

After then discussing the nature of false imprisonment which Russell treated as an assault, ${ }^{431}$ the author continued in respect of accidental batteries:

Whether the act amounted to an assault must, in every case, be collected from the intention... if the injury committed were accidental and undersigned, it will not amount to a battery. Thus, if one soldier hurts another by discharging a gun in exercise, it will not be a battery. ${ }^{432}$ And it is no battery if, by a sudden fright, a horse runs away with its rider, and runs against a man. ${ }^{433}$ So where upon an indictment for throwing down skins into a man's yard, being a public way, by which a person's eye was beaten out, it appeared by the evidence, that the wind blew the skin out of the way, and that the injury was caused by the circumstance, the defendants were acquitted. ${ }^{434}$

\section{(d) Defences}

Russell referred to the same defences as Hawkins. Thus, he referred to self- defence, defence of certain others, legal justification and lawful correction:

In some cases force used against the person of another may be justified, and will not amount to an assault and battery. Thus, if an officer having a warrant against one who will not suffer himself to be arrested, beat or wound him, in an attempt to take him; or if a parent, in a reasonable manner, chastise his child; or a master his servant, being actually in his service at the time; or a schoolmaster his scholar; or a gaoler his prisoner; or if one confine a friend who is mad, and bind and beat him, etc. in such a manner as is proper in such circumstances; or if a man force a sword from one who offers to kill another therewith; or if a man gently lay his hands upon another, and thereby stay him from inciting a dog against a third person; no assault or battery will be committed by such acts. ${ }^{435}$

A wife may justify an assault in defence of her husband. ${ }^{436}$ It has been holden that a defendant may justify even a mayhem, if done by him as an officer in the army, for disobeying orders... ${ }^{437}$

Russell also referred to consent ${ }^{438}$ and to the right of a person to protect his land and goods:

So if A beat B (without wounding him, or throwing at him a dangerous weapon) who is wrongfully endeavouring, with violence, to dispossess him of his lands, or of the goods, either of himself or of any other person, which have been delivered to him to be kept, and will not desist upon A's laying his hands

\footnotetext{
${ }^{428}$ Russell referred in a footnote to precedents contained in J Chitty, A Practical Treatise on the Criminal Law (1819, containing precedents of indictments. See $\mathrm{n}$ 261).

${ }^{429}$ Russell cited Scott $v$ Shepherd (see 18). See also D Ibbetson, A Historical Introduction to the Law of Obligations (OUP, 1999$)$ ), p 162. Squibs (fireworks) were regulated by $9 \& 10 \mathrm{~W} 3$ c 7 (1697, rep) (fine for throwing squibs in the street etc.).

${ }^{430}$ Russell cited Short $v$ Jovejoy (1752) (see 18).

${ }^{431}$ See also McBain, $\mathrm{n} 4$.

${ }^{432}$ Russell cited Weaver $v$ Ward (see 14), Rolle, n 21, vol 2, p 548 and Bacon. Russell continued in the fn 'But if the act were done without sufficient caution, the soldier would be liable to an action at the suit of the party injured: for no man will be excused from a trespass, unless it be shewn to have been caused by inevitable necessity, and entirely without his fault.' Russell cited Dickenson v Watson (see 14), Underwood $v$ Hewson (see 18) and Selwyn. See also Baker, n 160, p 405.

${ }^{433}$ Russell cited Gibbons $v$ Pepper (see 14) and continued 'But if the horse running against the man were occasioned by a third person whipping him, such third person would be a trespasser.' Russell cited Bacon and continued 'And, upon the principles which have been before-mentioned, such an act in a third person, causing death to any one, may, under certain circumstances, amount to felony.'

${ }^{434}$ Russell referred to Gill (see 18).

${ }^{435}$ Russell referred to Hawkins and Bacon.

${ }^{436}$ Russell cited Leward v Baseley (see 14).

${ }^{437}$ Russell cited Lane v Degberg (see 14).

${ }^{438}$ Russell, $n$ 38, vol 1, p 867. 'It seems also... that if two, by consent, play at cudgels, and one happen to hurt the other, it would not amount to a battery, as their intent was lawful and commendable, in promoting courage and activity.' Russell cited Bacon, Dalton and Brooke (title Coron), no 229 (see n 196).
} 
gently upon him, and disturbing him; or if a man beat, wound, or maim, one who is making an assault upon his own person, or that of his wife, parent, child, or master; or if a man fight with, or beat, one who attempts to kill any stranger; ${ }^{439}$ in these cases also it seems that the party may justify the assault and battery. ${ }^{440} \ldots$

It should be observed, with respect to an assault by a man on a party endeavouring to dispossess him of his land, that where the injury is a mere breach of a close, in contemplation of law, the defendant cannot justify a battery without a request to depart; but it is otherwise where any actual violence is committed, as it is lawful in such case to oppose force to force: therefore, if a person breaks down the gate, or come into a close vi et armis, the owner need not request him to be gone, but may lay hands on him immediately; for it is but returning violence with violence. ${ }^{441}$

So if one come forcibly and take away another's goods, the owner may oppose him at once, for there is no time to make a request. ${ }^{442}$ But, in general, unless there be violence in the trespass, a party should not, either in defence of his person, or his real or personal property, begin by striking the trespasser, but should request him to depart or desist, and if that is refused, should gently lay hands upon him in the first instance, and not proceed with greater force than is made necessary by resistance. ${ }^{43}$ Thus, where a churchwarden justified taking off the hat of a person who wore it in church, at the time of divine service, the plea stated, that he first requested the plaintiff to be uncovered, and that the plaintiff refused. ${ }^{44}$

\section{(e) Defences - Pre-emptive}

Russell also noted that a person might act pre-emptively:

And in all cases where the force used is justified, as not amounting to an assault, under the particular circumstances of the case, it must appear that it was not greater than was reasonably necessary to accomplish the lawful purpose intended to be effected. ${ }^{45}$ Therefore, though an offer to strike the defendant, first made by the prosecutor, is a sufficient assault by him to justify the defendant in striking, without waiting till the prosecutor had actually struck him first; yet even a prior assault will not justify battery, if such battery be extreme; and it will be matter of evidence whether the retaliation by the defendant were excessive, and out of all proportion to the necessity or provocation received. ${ }^{446}$

\section{(f) Minor Assaults \& Batteries}

Long before, Bracton (c.1240) had spoken of the fact that the criminal law should not deal with trivial batteries. As to these, Russell stated:

This offence is punishable as a misdemeanour: and the punishment usually inflicted is fine, imprisonment, and the finding of sureties to keep the peace. But as the offence, though undoubtedly in some degree concerning the public, principally and more immediately affects an individual, the defendant is frequently permitted by the court to speak with the prosecutor, after conviction and before any judgment is pronounced; and if the prosecutor declares himself satisfied, a trivial punishment, generally a fine of a shilling, is inflicted. 447

\section{In conclusion, Russell defined assault as ' an attempt or offer, with force and violence, to do a corporal hurt to another' and battery as 'any injury...done by... a man, in an angry or revengeful, or rude, or insolent manner.' The latter borrowed from Hawkins and was incorrect. Russell usefully noted that a battery could be direct or indirect.}

\footnotetext{
439 Although Russell referred to a 'stranger' this extension was not to be adopted and subsequent legal writers continued to refer to certain 'family' categories, until Kenny (in 1904, see 27).

${ }^{440}$ Russell referred to Hawkins ('and the numerous authorities there cited') and to Bacon.

441 Russell cited Green v Goddard (see 18) and Leward v Baseley (see 14).

${ }^{442}$ Russell cited Green v Goddard (see 18).

${ }^{443}$ Russell cited Weaver v Bush (1798) 8 TR 78 (101 ER 1276). In an action for assault and battery, D may plead that P, with force and arms and with a strong hand, endeavoured forcibly to break and enter D's close whereupon D resisted and opposed such entrance etc. and if any damage happened to $\mathrm{P}$, it was in defence of possession of the said close. Kenyon CJ, p 81 stated: 'A party may resist and oppose force by force in defence of his possession, if necessary: if the resistance be excessive, the plaintiff may show that in a new assignment.' See also Selwyn.

444 Russell cited Haw v Planner (see 18).

445 Russell cited East.

446 Russell cited cited Buller and East.

447 Ibid. Russell, n 38, vol 1, p 872 then considered various statutory aggravated assaults (they are not discussed her since they have long been repealed).
} 


\section{Archbold (1822) \& Hawkins (1824)}

Archbold, in the first edition of his Summary of the Law relative to Pleading and Evidence in Criminal Cases (1822), stated:

An assault is an attempt to commit a forcible crime against the person of another: such as an attempt to commit a battery, murder, robbery, rape etc... Striking at another with a cane, stick, or fist, although the party striking misses his aim; ${ }^{448}$ drawing a sword or bayonet, or throwing a bottle or glass, with intend [sic] to wound or strike; presenting a gun at a man who is within the distance to which the gun will carry; pointing a pitchfork at him, when within reach of it; or any other act indicating an intention to use violence against the person of another, is an assault. ${ }^{49}$ Mere words, however, can never amount to an assault. So if a man strike at another, but at such a distance that he cannot by possibility touch him, it is no assault. ${ }^{450}$

A battery, in the legal acceptation of the word, includes beating and wounding. To beat, also in the legal acceptation of the term, means not merely to strike forcibly with the hand, or a stick, or the like, but includes every touching (however trifling) of another's person, in an angry, revengeful, rude, or insolent manner ${ }^{451}$ as for instance, thrusting or pushing him, in anger ${ }^{452}$...holding him by the arm; spitting in his face ${ }^{453}$...jostling him out of the way; ${ }^{454}$ pushing another man against him ${ }^{455}$... throwing a squib at him ${ }^{456}$ striking a horse upon which he is riding, whereby he is thrown; ${ }^{457}$ or the like. If a man strike at another with a cane or fist, or throw a bottle at him, or the like: if he miss him, it is an assault; if he hit him, it is a battery. A wounding is where the violence is so great as to draw blood, by striking or stabbing with sword, knife, or other instrument; or by shooting, or by striking with a cudgel, or fist, or the like. ${ }^{458}$

Archbold then noted that it was a good defence to prove that the alleged battery:

- happened by misadventure (i.e. by accident); ${ }^{459}$ or

- was consensual (i.e. pursuant to 'an amicable contest'); ${ }^{460}$ or

- comprised lawful correction (the correcting of a child by his parent or a servant (or scholar) by his master); ${ }^{461}$ or

- was in self-defence; ${ }^{462}$ or

- in defence of others; ${ }^{463}$ or

\footnotetext{
${ }^{448}$ Rolle, n 21, vol 2, 545, 145.

${ }^{449}$ Archbold cited Hawkins.

${ }^{450}$ Archbold, n 39, pp 241-2. Archbold cited Comyns, see n 26, vol 2 (battery).

${ }^{451}$ Archbold cited Hawkins.

${ }^{452}$ Archbold cited Holt CJ in Cole v Turner (see 14).

${ }^{453}$ Archbold cited Cotesworth (see 14). See also R v Lynsey [1995] 3AE 654.

${ }^{454}$ Archbold cited Cole v Turner (see 14).

${ }^{455}$ Archbold cited Buller.

${ }^{456}$ Archbold cited Scott $v$ Shepherd (see 18).

${ }^{457}$ Archbold cited Anon (see 14).

${ }^{458}$ Archbold, n 39, p 242.

459 Ibid, p 243.

${ }^{460}$ Ibid 'as, that he wrestled with the prosecutor for a wager. So, that it happened by accident whilst the D was engaged in some sport or game, which was neither unlawful nor dangerous...is a good defence.'

${ }^{461}$ Ibid. Archbold referred to Comyns and Hawkins. Also, to Watson v Christie (1800) 2 B \& P 224 (126 ER 1248 (excessive chastisement of a crew member by the ship's captain. Fined £500). Archbold continued 'provided the correction be moderate, in the manner, the instrument, and the quantity of it, or that the criminal be punished in the manner appointed by law...'.

${ }^{462} \mathrm{Ibid}$ 'It is a good defence, in justification even of a wounding or mayhem, to prove that the prosecutor assaulted or beat the D first, and that the D committed the alleged battery merely in his own defence... if he prove an assault merely, as, for instance, that the prosecutor lifted up his staff and offered to strike him, it is sufficient to justify the D's striking him, for he need not, in such a case, stay till the other has actually struck him...So, a husband may justify a battery in defence of his wife, a wife in defence of her husband, a parent in defence of his child, a child in defence of his parent, a master in defence of his servant, and a servant in defence of his master.... But in all these cases, the battery must be such only as was necessary to the defence of the party or his relation; for if it were excessive, if it were greater than was necessary for mere defence, the prior assault will be no justification...Also, it will be sufficient answer to this defence, to prove that the first assault was justifiable... "

${ }^{463}$ See $\mathrm{n} 462$ above.
} 
- in defence of possessions; ${ }^{464}$ or

- $\quad$ in accordance with justice. ${ }^{465}$

The last edition of Hawkins was in 1824 and (as noted previously, see 14) it reflected little change to the position in 1716, save for some more caselaw. 466

In conclusion, Archbold (in 1822) and the last edition of Hawkins (in 1824) added little to Russell (who commenced writing in 1819 on assault and battery). Russell became the most important commentary on this subject after Hawkins.

\section{Gabbett (1843)}

Gabbett, in his Treatise on Criminal Law (1843), considered the law on assault and battery.

\section{(a) Assault}

As to a definition of assault, Gabbett stated:

any attempt or offer with force and violence to do a corporal hurt to another, whether from malice or wantonness, as by striking at him, with or without a weapon, throwing a bottle of glass with intent to wound or strike, drawing a sword or bayonet, or even holding up one's fist at him, in an angry or threatening manner, is an assault, which, as a disturbance of the public peace, is indictable at common law ...

It is also essential that the circumstances of the attempt or inchoate violence must not only be such as to denote the intention, but be coupled, at the time, with an ability of using actual violence against the person who is the object of it: as by pointing a pitchfork or other weapon at him, when he is within reach of it; or presenting a gun at him at such a distance to which the gun will carry. ${ }^{467}$

\section{(b) Battery}

As to the definition of battery, Gabbett stated:

when the injury which is menaced or intended, be it never so small, is actually inflicted, it is then distinguishable as a battery, as by spitting in a man's face, or any way touching him in an angry, revengeful, rude, or insolent manner, without lawful cause, a 'battery' not being confined to a violent striking, which the term in common parlance imports, but extending even to the laying on of hands against a person's will ${ }^{468}$ for the law cannot draw the line between different degrees of violence, and therefore totally prohibits the first and lowest stage of it; every man's person being sacred, and no other having a right to meddle with it, in any the slightest manner, ${ }^{469}$ except in such cases as amount to a special jurisdiction.

Gabbett also noted that:

Assault may be direct or indirect. It was unnecessary to constitute an assault (or battery) that the injury

\footnotetext{
${ }^{464}$ Ibid, p 244. 'The D may justify a battery, by proving that he committed it in defence of his possession; as, for instance, to remove the prosecutor out of his close or house...or to prevent him from entering it...to restrain him from taking or destroying his goods, etc... from taking or rescuing cattle etc. in his custody upon a distress....or the like. In the case of a trespass in law, merely, without actual force, the owner of the close, etc. must first request the trespasser to depart, before he can justify laying his hand on him for the purpose of removing him; and even if he refuse, he can only justify so much force as is necessary to remove him.... But if the trespasser use force, then the owner may oppose force to force.... and in such a case, if he be assaulted or beaten, he may justify even a wounding or mayhem, in self defence, as mentioned above. In answer, however, to a justification in defence of his possession, the other party may prove that the battery was excessive... or justify the alleged trespass on the defendant's possession, by proving that he had a right of way over the close, or the like.'

${ }^{465}$ Ibid. 'It is a good defence to prove that the D, as an officer of justice, arrested the prosecutor by virtue of a certain writ of process, which is the alleged battery complained of...A sheriff's officer, however, can only justify laying his hand upon a man, in order to arrest him upon a writ or process; unless he resist, or an attempt be made to rescue him... and even then, he can justify no greater degree of force than was necessary in order to secure his prisoner. And the same as to officers of justice, and persons acting in their aid, arresting on suspicion of felony, without warrant; and as to private persons arresting men committing felonies in their presence... So, a man may justify laying his hand upon another to prevent him from fighting, or committing a breach of the peace...or to prevent him from rescuing goods taken in execution...Y Yet even in these cases he must not use more force than is requisite to restrain the other party; otherwise he can avail himself of the threatened breach of the peace, etc. as a justification.'

466 The only difference related to the citation of cases in the fns. These are reflected in the footnotes to 15 .

${ }^{467}$ Gabbett, n 40, vol 1, p 81. Cobbett v Grey (1849) 4 Ex 727, 744 per Pollock CB '[I]f you direct a weapon, or if you raise your fist within those limits which give you the means of striking, that may be an assault.'

${ }^{468}$ Gabbett cited Uxv Tebbart (see 14). Also, Bacon, see $\mathrm{n} 25$.

${ }^{469}$ Gabbett cited Blackstone (see 17).
} 
should be effected directly by the hand of the party. Thus, there could be an assault by: (a) encouraging a dog to bite; or (b) pushing a drunken man against another; or (c) willfully and violently driving a cart, etc. against the carriage of another, causing bodily injury to the persons travelling in it; or (d) a squib being thrown through various hands to reach the victim; ${ }^{470}$

Violence. An assault did not only necessarily imply a striking or beating or violence to the person. It was not even required the corporal touch should be in anger. Therefore, 'indecent liberties' with a female against her will, though no resistance was made, was an assault. ${ }^{471}$

Gabbett noted that assaults on the person of another might be justified, citing Hawkins and Bacon ${ }^{472}$ In particular, he referred to self defence ${ }^{473}$ which should be preventive (and not vindictive) ${ }^{474}$ and reasonable, ${ }^{475}$ although it could be pre-emptive. ${ }^{476}$

\section{In conclusion, Gabbett usefully noted that assaults and batteries could be indirect as well as direct and that violence (anger, hostility) was not a requirement (effectively correcting Hawkins on this).}

\section{Burn (1869) \& Selwyn (1869)}

It is instructive to consider the final edition of Burn on Justice of the Peace (in 1869) as well as the final edition of Selwyn on Nisi Prius (1869) ${ }^{477}$ since they reflect how little the law between 1716-1869 had changed in respect of assault and battery - including definitions and defences.

\section{(a) Assault}

Burn stated:

An assault (assultus, from the French assayler) is an attempt to offer or offer, with force and violence,

\footnotetext{
${ }^{470}$ Gabbett cited Scott $v$ Shepherd (see 18).

${ }^{471}$ Gabbett referred to Nichol (1807) Russ \& Ry 130 (168 ER 720)(if a master takes indecent liberties with a female scholar, without her consent, although she does not resist, he is liable for assault). Also, to R v Rosinski (1824)(1 Mood 19 (168 ER 1168)(D, a doctor, made a female patient strip on the pretence that it was necessary for him to diagnose her. If he had taken off her clothes it would have been an assault).

${ }^{472}$ Gabbett, $\mathrm{n}$ 40, vol 1, $\mathrm{p}$ 83: stated 'thus, if an officer having a warrant against one who will not suffer himself to be arrested, or endeavours to rescue himself, beat or wound him in the attempt to take him; or if a parent, in a reasonable manner, chastise his child, or a master his servant, being actually in his service at the time; or a schoolmaster his scholar; or a gaoler his prisoner; of if one confine a friend who is mad, and bind and beat him etc. in such a manner as is proper in the circumstances; or if a man force a sword from one who offers to kill another therewith; or if a man gently lay his hands upon another, and thereby stay him from inciting a dog against a third person: so if a man beat another (without wounding him, or throwing at him a dangerous weapon) who is wrongfully endeavouring, with violence, to dispossess him of his hand or goods, or the goods of another delivered to him to be kept for him, and will not desist upon his laying his hands gently on him, and disturbing him; or if a man beat, wound, or maim one who is making an assault upon his own person, or that of his wife, parent, child, or master, especially if it appear that he did all he could to avoid fighting, before he gave the wound; in all such cases the law excuses the assault.' Gabbett cited Hawkins.

${ }^{473}$ Ibid. 'And it seems that a man may also justify the assault or beating, if he fights with or beats one who attempts to kill any stranger: but he may clearly imprison or detain those whom he sees fighting, until the heat is over. A wife may also justify an assault in defence of her husband, but it does not seem to be so clearly settled that the master can justify an assault in defence of his servant...'

${ }^{474}$ Ibid 'The interposition in several of the cases above mentioned ought to be preventive, and not vindictive: as where the wife uses force in defence of her husband, or a man in defence of his wife, parent, child, or master.'

${ }^{475}$ Ibid. 'And in all cases where the force used is justified, under the particular circumstances, as not amounting to an assault, it should appear that it was not greater than was reasonably necessary to accomplish the lawful purpose intended to be effected and therefore though an offer to strike the D, first made by the prosecutor, is a sufficient assault by him to justify the D in striking, without waiting until the prosecutor has actually struck him first, yet even a prior assault will not justify a battery, if such battery be extreme, and it will be a matter of evidence whether the retaliation by the $\mathrm{D}$ was excessive, and out of all proportion to the necessity, or provocation received.' Gabbett cited Buller and East.

${ }^{476}$ Ibid. 'in general, unless there be violence in the trespass, a party should not, either in defence of himself or any other person, or of his or their real or personal property, begin by striking the trespasser; but should request him to depart or desist; and if that is refused, should gently lay his hands upon him in the first instance, and not proceed with greater force than is made necessary by the resistance. But if one come forcibly, and take away another's goods, the owner may oppose him at once, for there is no time to make a request: and so if a person break down the gate of a close, or enter it with considerable violence, the owner need not request him to be gone, but lay hands on him immediately; for it is but returning violence with violence. Gabbett cited Weaver v Bush (see n 443), Haw v Planner (see 14) and Green v Goddard (see 18).

${ }^{477}$ The last edition of Selwyn is cited only, since prior editions add little. The first edition was in 1806-8 (see n 43). See also J Paterson, Commentaries on the Liberty of the subject and the Laws of England relating to the Security of the Person (Macmillan, 1877), pp 288-9 'An assault consists in an attempt to touch or strike another's person against his will, or in using an imminent threat to do so forthwith...An assault is resolvable into four elements - (1) the intention of the assailer; (2) the attempt to touch the person, or the threat to do so forthwith; (3) the non-consent of the assaulted; and (4) the want of a lawful excuse. A battery...denotes...when an actual blow has been given, direct or proximate, or a touch accompanied with insolence or anger.' Paterson also considered the various defences to assault, see pp 293-310 ( a useful summary of the law by 1877).
} 
to do a corporal hurt to another, whether from malice or wantonness. ${ }^{478}$

Selwyn similarly stated:

An assault is an attempt, with force or violence, to do a corporal injury to another against his will. ${ }^{479}$

Burn noted that the mere passive obstruction of a person's progress (e.g. a person placing himself passively in a person's way, obstructing entrance into a room) was not an assault. ${ }^{480} \mathrm{He}$ also noted that mere words did not constitute an assault. ${ }^{481}$

\section{(b) Battery}

Burn defined battery as follows:

Battery (from the Saxon batte, a club, or beaten, to beat, from whence cometh also the word battle) seemeth to be, when any injury whatsoever, be it ever so small, is actually done to the person of a man in an angry, or revengeful, or rude, or insolent manner...The hurt or touch must be with a hostile intention, and therefore, a touch given by a constable's staff for the purpose of engaging a person's attention only is not a battery. ${ }^{482}$

Selwyn stated:

A battery, which always includes an assault, is an injury inflicted on a person by beating, either with the hand or an instrument, or by any substance put or continued in motion by him, by throwing water even. $^{483}$

\section{(c) Defences}

Both Burn ${ }^{484}$ and Selwyn ${ }^{485}$ referred to the same defences as in past times, viz.

- $\quad$ self-defence (but it must be proportionate);

- defence of relations (i.e. a wife, children and servants as well as their defence of their parent or master);

- defence of land and goods;

- lawful correction (i.e. of a schoolmaster, parent or gaoler);

- legal justification;

- $\quad$ contest (i.e. amicable contests or lawful games). ${ }^{486}$

\section{In conclusion, Burn and Selwyn did not add anything substantive to the law on assault and battery.}

\section{Harris (1881) \& Stephen (1883)}

\section{(a) $\underline{\text { Harris (1881) }}$}

Harris, in the second edition of his Principles of the Criminal Law (1881), ${ }^{487}$ stated:

\footnotetext{
${ }^{478}$ Burn, n 35, vol 1, p 308. Burn continued 'as by striking at him with or without a weapon, though the party striking misses his aim; so drawing a sword, throwing a bottle or glass, with intent to wound or strike, presenting a loaded gun or pistol at a person within the distance to which the gun or pistol will carry, or pointing a pitchfork at a person standing within reach; holding up one's fist at him, in a threatening or insulting manner, or with such other circumstances as denote at the time an intention (coupled with a present ability) of using actual violence against his person, will amount to an assault.'

${ }^{479}$ Selwyn, $\mathrm{n} 43$, vol 1, p 41. Selwyn continued: 'as by holding up a fist in a menacing manner; striking at another with a cane or stick, thought the party striking misses his aim; drawing a sword or bayonet; throwing a bottle or glass with intent to wound or strike; presenting a gun at a person who is within the distance to which the gun will carry; pointing a pitchfork at a person who is within reach; or by any other similar act, accompanied with such circumstances as denote at the time an intention, coupled with a present ability, of using actual violence against the person of another, as by $\mathrm{D}$ and his servants surrounding the $\mathrm{P}$, tucking up their sleeves and threatening to break his neck if he did not leave their shop... Whether the act shall amount to an assault must in every case be collected from the intention.'

${ }^{480}$ Burn cited Innes $v$ Wylie (1844) 1 Car \& K 257 (174 ER 800)(policeman passively obstructed a person from entering a room). Denman CJ at 263 'If the policeman was entirely passive like a door or a wall put to prevent the $\mathrm{P}$ from entering, and simply obstructing the entrance of the P, no assault has been committed on the P.' See also Trindade, n 319, p 226.

${ }^{481}$ Burn, $\mathrm{n} 35$, at $\mathrm{p} 309$

482 Ibid, p 312. Burn cited Wiffin v Kennard (1807) 2 B \& P 471 (127 ER 713)(in an action for assault, battery and false imprisonment, a constable touched a man with his staff, desiring him to get down from some railings). Per J Mansfield, $\mathrm{p} 472$ 'The court were clearly of the opinion that the touch given by the constable's staff, in order to engage the P's attention, did not amount to a battery.'

${ }^{483}$ Selwyn, $\mathrm{n} 43, \mathrm{p} 42$.

${ }^{484}$ Burn, n 35, pp 312-5.

${ }^{485}$ Selwyn, $n$ 43, pp 47-50.

${ }^{486}$ Burn, n 35, pp 314-5.
} 
An assault is an attempt or offer to commit a forcible crime against the person of another; for example, presenting a loaded gun at a person. It will be noticed that there need not be an actual touching of the person assaulted. But mere words never amount to an assault. ${ }^{488}$

A battery is not necessarily a forcible striking with the hand or stick or the like, but includes every touching or laying hold (however trifling) of another person, or his clothes, in an angry, revengeful, rude, insolent or hostile manner; for example jostling another out of the way. Thus, if a man strikes at another with a cane or fist, or throws a bottle at him, if he misses it is an assault; if he hit, it is a battery. 489

\section{(b) Stephen (1883)}

The eminent criminal jurist and judge Sir James Fitzjames Stephen did not deal with assault and battery in his History of the Criminal Law (in 1883). However, in his Digest of the Criminal (1883), article 241, he defined assault and battery as follows:

An assault is (a) an attempt unlawfully to apply any the least actual force to the person of another directly or indirectly, (b) the act of using a gesture towards another giving him reasonable grounds to believe that the person using that gesture meant to apply such actual force to his person as aforesaid, (c) the act of depriving another of his liberty, in either case without the consent of the person assaulted or with such consent if it is obtained by fraud. ${ }^{490}$

A battery is an assault whereby any the least actual force is actually applied to the person of another, or to the dress worn by him, directly or indirectly.

Provided that such acts as are necessary for the reasonable intercourse of life, are not assaults or batteries if they are done for the purpose of such intercourse only and with no greater force than the occasion requires. No mere words can in any case amount to an assault.

Stephen provided various examples of assault ${ }^{491}$ and battery. ${ }^{492}$ He also formulated separate articles to deal

${ }^{487}$ Harris, $\mathrm{n} 41$

${ }^{488}$ Ibid, p 179. Harris cited Hawkins. Harris continued 'The unlimited character of this crime makes it a convenient method of punishing a variety of crimes which do not at first sight seem to be assaults, at least not in the popular signification of the term; for example, putting a child in a bag, hanging it on some palings, and there leaving it.' Harris cited $R v$ March (1844) 1 C \& K 496 (174 ER 909).

${ }^{489}$ Ibid. Harris continued 'As a rule, consent on the part of the complainant deprives the act of the character of an assault, unless, indeed, non-resistance has been brought about by fraud. But the fact of consent will in general be immaterial when an actual battery or breach of the peace has been committed'

${ }^{490}$ See also Draft Criminal Code of 1878 ('CC-1878') 'An assault is the act of intentionally applying force to the person of another directly or indirectly, or attempting or threatening by any act or gesture to apply such force to the person of another, if the person making the attempt or threat has, or causes the other to believe upon reasonable grounds that he has, present ability to effect such purpose.' See Irish University Press Series of British Parliamentary Papers. Royal Commission Select Committee and Other Reports on the Criminal Law with Proceedings Minutes of Evidence Appendix and Index 1847-79, p 474. It is also interesting to note the definition of assault in HAD Phillips, Manual of Indian Criminal Law ( ${ }^{\text {nd }}$ ed, 1887), art 351 'Whosoever makes any gesture or any preparation, intending or knowing it to be likely that such gesture or preparation will cause any person present to apprehend that he who makes that gesture or preparation is about to use criminal force to that person, is said to commit an assault.' Phillips was of the Bengal Civil Service and his Manual was intended for Indian magistrates. As examples, Phillips cited: (a) A shakes his fist at Z, intending (or knowing) it to be likely that he may thereby cause Z to believe that A is about to strike Z; (b) A begins to unloose the muzzle of a ferocious dog, intending (or believing) it to be likely that he may thereby cause $\mathrm{Z}$ to believe that he is about to cause the dog to attack Z; (c) A takes up a stick, saying to Z 'I will give you a beating.' Here, though the words used by A could in no case amount to an assault, and though the mere gesture, unaccompanied by any other circumstances, might not amount to an assault, the gesture explained by the words may amount to an assault.'

${ }_{491}$ (a) A strikes at B with a stick, without hitting him; (b) A aims a pistol at B which A knows is unloaded, but which B believes to be loaded. Stephen cited Hawkins and $R v$ St George (1840) 9 C \& P 483 (173 ER 921) per Parke B at p 493 'it is an assault to present a pistol at all, whether loaded or not.' Stephen also asserted that no assault or battery was committed in the cases where: (a) A lays his hand on B to attract his attention; (b) A, falling down, catches hold of B to save himself; (c) A crowd of people, going into a theatre, push and are pushed against each other.

492 (a) A cuts B's dress while B is wearing it, but without touching (or intending to touch) any part of B (Stephen cited Day (1845) 1 Cox CC 207(used a penknife to scar the frock of the P). Per Parke B 'it is an assault on a man's person to inflict injury to the clothes on his back. In the ordinary case of a blow on the back, there is clearly an assault, though the blow is received by the coat on the person'); (b) A sets a dog at $\mathrm{B}$, which bites the latter (Stephen indicated that Russell cited many cases); (c) A man professing to act as a medical adviser fraudulently induces a girl to all him to undress her, falsely alleging it is necessary for medical reasons (Stephen cited Rosinski (see $\mathrm{n} 471$ ) and $R v$ Case (1850) 1 Den 580 (169 ER 381)(Doctor had sex with a patient pretending to treat her medically. She made no resistance since she thought it was part of the treatment. Held assault. Per Platt B, p 583 'Her non-resistance was caused by the prisoner's fraud.'); (d) A touches a boy of 8 in an indecent manner, B acquiescing in ignorance of the nature of the act (Stephen cited $R v$ Lock (1872) 2 CCR 10 and $R v$ Barnett (1873) 2 CCR 81); (e) A induces B to have sex with him, pretending to be her husband (Stephen cited $R v$ Williams (1838) 8 C \& P 286 (173 ER 497)(a man had sex with a woman who consented, thinking it was her husband, an assault)). 
with various aggravated assaults. ${ }^{493}$

In conclusion, the commentary of Harris added nothing to the substantive law on assault and battery and the definition of Stephen is insufficient in that it did not reflect the actus reus and mens rea of assault and battery in sufficient detail. ${ }^{494}$

\section{Summary of the Law from 1721-1883}

The development of the law of assault and battery - in terms of legal writers and caselaw - may be stated succinctly:

- $\quad$ Legal Writers. Burn (1755-1869), Finch (1759), Blackstone (1768-9), ${ }^{495}$ Buller (1788), East (1803), Archbold (1822), Selwyn (1869), Harris (1881) and Stephen had little to say on assault and battery. And, what they did say, tended to be heavily influenced by Hawkins (1716-1824) or Russell (which text commenced in 1819). Thus, the main texts of interest during this period are Hawkins and Russell, although commentary by Gabbett (1843) is also useful;

- $\quad$ Assault \& Battery - Definitions. The definitions of assault and battery changed little from the time of Hawkins. Thus,

○ Hawkins (assault, in 1824, last edition) 'an attempt, or offer, with force and violence, to do a corporal hurt to another', (battery) 'any injury whatsoever, be it never so small, being actually done to the person of a man, in an angry, or revengeful, or rude, or insolent manner.'

- Russell (assault) 'an attempt or offer, with force and violence, to do a corporal hurt to another'

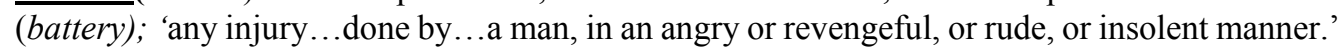

- Gabbett (assault) 'any attempt or offer with force and violence to do a corporal hurt to another... as to denote the intention... coupled... with an ability of using actual violence', (battery) 'when the injury which is menaced or intended, be it never so small, is actually inflicted.'

The problem with these definitions is that they did not reflect the actus reus or mens rea of these offences in detail - not least because none of the writers in this period analysed the same in any detail. Further, various parts of the definitions were incorrect ${ }^{496}$ or unnecessary; ${ }^{497}$

- $\quad$ Assault \& Battery - Mens Rea. It had been accepted early on that criminal liability applied where the assault or battery was intentional but not when accidental ${ }^{498}$ or negligent. ${ }^{499}$ The question of recklessness in the criminal aspect was not considered by legal writers until Kenny (see 27) and not fully accepted until much later in the $20^{\text {th }}$ century (see Venna (1975), see 30). It was accepted in Victorian times that hostility, or anger, was not needed (e.g. Gabbett 1843, see 23);

- Defences. The same defences as in the time of Hawkins (and back to Marow in 1503) were accepted. In particular, it was accepted that self-defence, defence of certain others (one's wife, children etc.) and defence of one's land and goods had to be proportionate (though it could be pre-emptive). Also, that lawful correction had to be in moderation (reasonable). Further, assault and battery, for the purposes of the criminal law, did not include minor (i.e. every day) assaults and batteries; ${ }^{500}$

\footnotetext{
${ }^{493}$ Thus, (a) art 242 (assault with intent to commit sodomy or indecent assault on a male), (b) art 243, assaults on persons protecting wreck; (c) art 244, assaults occasioning actual bodily harm; (d) art 245, assaults punishable with 2 years imprisonment (including assaults on police officers and clergymen); (e) art 247, assaults on officers preventing smuggling; (f) art 251, assaults punishable with 3 months imprisonment (including assaults on persons selling grain and on seamen).

${ }^{494}$ In (c), Stephen included false imprisonment which is a separate offence (and was then).

${ }^{495}$ The final edition of Blackstone was in 1841, see Stephen, $\mathrm{n} 36$. The definition of assault was identical to that in 1768 and that of battery had one word removed (instead of 'unlawful beating of another' it was 'beating of another'). See Stephen, vol 3, p 469.

${ }^{496} \mathrm{Viz}$.(a) an assault is not an attempt (or offer) to batter (i.e. an attempted battery) since there may be no such intention; (b) an assault or battery does not require force, violence or hostility - nor rudeness, revenge or insolence. It can be committed by the lightest touch; (c) assault and battery can be committed recklessly as well as intentionally.

497 e.g. 'offer' was a synonym for 'attempt.'

498 e.g. Gill (1791) (see 18), Keite (1696)(see 14). The proposition that a person was not criminally liable in the case of an accident or negligence, goes back to the Laws of Henry I (c.1113), see ns 103 \& 104.

499 Ibid.

${ }^{500}$ The right to take pre-emptory action was accepted as early as the Laws of Henry I (c. 1113), see n 102. Proportionality re self-defence etc. was accepted by 1400 (see n 172). Bracton (c. 1240) was asserting that trivial batteries did not count in his time (see 7).
} 
- Assault \& Battery. It was accepted that the assault or battery could be either direct or indirect, something Roman law had also accepted. ${ }^{501}$ However, the act must be present (i.e. actual, immediate) and not future. The act could be against the person or (pursuant to caselaw) the clothes on him. ${ }^{502}$ It was accepted (by caselaw) that assault and battery could not be by omission. ${ }^{503}$

\section{Kenny (1904)}

In the second edition of his text, Outlines of the Criminal Law (in 1904), Kenny stated:

\section{(a) Definition of Assault \& Battery}

An 'assault' is an attempt, or offer, with force and violence, to do a corporal hurt to another. ${ }^{504} \mathrm{~A}$ battery is an injury done to the person of a man in an angry, revengeful, rude or insolent manner. ${ }^{505}$ In other words, an assault is a movement which attempts, or threatens, the unlawful application of force to another person; whilst such an application itself, when actually effected, constitutes a battery. Thus riding at a person is an assault, ${ }^{506}$ riding against him is a battery. ${ }^{507}$

Alarm is essential to an assault. Hence if a person who strikes at another is so far off that he cannot by possibility touch him, it is certainly no assault. ${ }^{508}$ And it has even been said that to constitute an assault there must, in all cases, be the means of carrying the threat into effect. ${ }^{509}$ Accordingly, whilst pointing a loaded pistol at a person is undoubtedly an assault, it was held in Reg $v$ James, ${ }^{510}$ that it was no assault to present an unloaded one. But in an earlier case, Reg $v$ St George, ${ }^{511}$ it was held, on the contrary, that if a person presents a firearm which he knows to be unloaded, at a man who does not know that it is unloaded, and who is so near that (were it loaded) its discharge might injure him, an assault is committed. ${ }^{512}$

One would assert that these cases of pointing pistols would be much more definitively decided today, it not being a matter of whether (in fact) it was loaded but, rather, how the D reacted. If he (reasonably) believed (apprehended) it to be loaded and that it would inflict a battery on him it should be an assault - not least since he should then have a right of self-defence (so that, if for example, he pushes away the arm of the person holding the pistol he then commits no battery). ${ }^{513}$

\footnotetext{
${ }^{501}$ See $\mathrm{n} 60$.

${ }^{502}$ See Day (1845, see n 492).

${ }^{503}$ See Innes $v$ Wylie (see n 480).

${ }^{504}$ Kenny, n 44, p 151 cited Hawkins. See also HW Disney \& H Gundry, The Criminal Law (Stevens \& Sons, 1895) p 135 'An assault in the strict sense of the word is an unlawful attempt to do a corporal hurt to another against his will, as by striking at him with or without a weapon...A battery is the unlawful beating of another; and, in law, the least touching of another's person, wilfully or in anger, is a battery.' Also 'An aggravated assault differs from a common assault in that it is a more serious assault, with aggravating circumstances, as when an assault causes grievous bodily harm.'

505 Ibid.

${ }^{506}$ Kenny cited Mortin v Shoppee (1828) 3 C \& P 373 (172 ER 462) (riding after a person and obliging him to run away into a garden, to avoid being beaten, is an assault).

${ }^{507}$ Kenny, n 44, p 151 . He continued 'A mere assault, even without a battery, is not only a tort but also a misdemeanour. Hence if a battery ensue, it does not enhance the degree of the crime; though it is important as affording clear proof of the hostile intention of the movements which constitute the assault. Usually, of course, both the two offences are committed together; and the whole transaction is legally described as 'an assault and battery'. This became shortened in popular language to 'an assault'; and now the common speech even of lawyers habitually uses that word as if synonymous with 'battery.'

${ }^{508}$ Kenny cited Comyns, Battery (C). See Comyns, n 26, (1792 ed), p 131 'But it is no assault, if a man speak menacing or provoking words against another in his absence. Or strike at him at such a distance that he cannot touch him, or put him in fear.'

${ }^{509}$ Kenny cited Stephens v Myers (1830) 4 C \& P 349 (172 ER 735)(A advanced with a threatening attitude to strike B, so that his blow would have almost immediately reached B, if he had not been stopped. Held to be an assault). Per Tindal CJ at $\mathrm{p} 350^{\circ}$ It is not every threat, when there is no actual personal violence, that constitutes an assault, there must, in all cases, be the means of carrying the threat into effect.' See also Trindade, n 319, pp 230-1.

${ }^{510}$ Kenny cited James (1844) 1 C \& K 530 (172 ER 735)(an assault to point a loaded pistol at anyone; but not, when it is proved not to be so loaded as to be able to be discharged).

${ }^{511}$ Kenny cited St George (see n 491).

${ }^{512}$ Kenny, $\mathrm{n} 44, \mathrm{p} 151$ continued 'This latter view, which makes the offence depend upon the alarm naturally (however mistakenly) aroused in the person threatened, is in accord with Scotch law; and it agrees with the predominance of authority in America, where this question has much more frequently come before the courts than in this country.'

${ }^{513}$ Whether he is fearful or terrified or not is also irrelevant. It is simply a matter of whether he believes that a battery is about to be inflicted on him.
} 


\section{(b) Discussion of Battery}

In a discussion of battery, Kenny stated:

Even in a battery, no actual harm need be done or threatened. The slightest force will suffice, if it were exercised in a hostile spirit; thus merely spitting at a person may amount to an indictable battery. The force applied (or threatened) need not involve immediate contact between the assailant and the sufferer. Thus it is sufficient if harm is done (or threatened) to a person's clothes without touching his skin. ${ }^{514}$ And, similarly, the hostile force may be exercised either directly or even indirectly, as by striking and horse and thereby making it throw its rider. ${ }^{515}$... some bodily movement is essential to an assault or battery; so that where there is only mere motionless obstruction ${ }^{516}$ - as where a cyclist is brought down by a collision with a person who only stands still, however wilfully, in front of him - no proceedings can be taken for assault. (The much graver offence of 'maliciously causing grievous bodily harm', may, however, have been committed). ${ }^{517}$

\section{(c) Definition of Battery}

Kenny cited the same defences as cited by Marow some 400 years before (with one or two less examples), ${ }^{518}$ viz:

- $\quad$ Self Defence \& Defending Others. Kenny noted that a person had a right to defend his own person ${ }^{519}$ as well as his wife, a child his parent, a master his servant or a servant his master ${ }^{520}$ and 'perhaps the courts would now take a still more general view of this duty of the strong to protect the weak. ${ }^{521} \mathrm{He}$ noted that such a right might be pre-emptive; ${ }^{522}$

- Defending Land \& Possessions. Kenny noted that a person had a right to defend his existing lawful possession of any property (whether land or goods); ${ }^{523}$

- Lawful Correction. A person might correct his own children or scholars (or apprentices) placed under his authority; ${ }^{524}$

\footnotetext{
${ }^{514}$ Kenny cited Day (n 492) per Parke B.

${ }^{515}$ Kenny cited cf. Dodwell v Burford (see 14).

${ }^{516}$ Innes $v$ Wylie (see n 480).

${ }^{517}$ Kenny, n 44, p 152. He cited Innes $v$ Wylie (see n 480). Kenny also stated 'Similarly, mere words, however threatening, can never make an assault. Yet they may unmake an assault. Kenny cited Turberville v Savage (see 14).

${ }^{518}$ References to villains and gaolers were absent.

${ }^{519}$ Ibid. 'In defending either (a) your person, or (b) your existing lawful possession of any property (whether it consist of lands or merely of goods).'
}

${ }^{520}$ Ibid. 'Nor is the right of defence limited to the particular person assailed; it includes all who are under any obligation, even though merely social and not legal, to protect him. The old authorities exemplify this by the case of a husband defending his wife, a child his parent, a master his servant, or a servant his master; (and perhaps the courts would now take a still more general view of this duty of the strong to protect the weak). A familiar modern instance is the force exercised by the stewards of a public meeting, to remove those who persistently disturb it.'

${ }^{521}$ Kenny cited US authority, J Bishop, Criminal Law of USA ( $8^{\text {th }}$ ed, 1892).

${ }^{522}$ Kenny, n 44, p 154 'Nature prompts a man who is struck to resist; and he is justified in using such a degree of force as will prevent a repetition'(citing Parke B in Anon (1836) 2 Lewin 48 (168 ER 1075)). Nor is it necessary that he should wait to be actually struck, before striking in self-defence. If one party raise up a threatening hand, then the other may strike.' Parke B in Anon stated, p 48 'If a party raise up a hand against another, within a distance capable of the latter being struck, the other may strike in his own defence to prevent him; but he must not use a greater degree of violence than is necessary. Where a man strikes at another, within a distance capable of being struck, nature prompts the party struck to resist it, and he is justified in using such a degree of force as will prevent a repetition.'

${ }^{523}$ Ibid. Also, p 155 'The right of self-defence extends, as we have said, to the defence not only of your person, but also of your property. Thus force may lawfully be used in expelling anyone who is trespassing in your house, or on your land, if no milder mode of getting rid of him would avail. Hence if his entry had itself been effected forcibly, as by a burglary or even by breaking open a gate, you may at once use force to expel him. But in the case of an ordinary peaceful trespasser, it will not be until you have first requested him to depart, and he has failed to comply with the request, that you will be justified in ejecting him by the strong hand. Disturbance of an easement is a wrong in the nature of a trespass, and therefore force may be used to prevent it.' Also, p 156 'A similar right exists in the case of movable property. Force may accordingly be used to resist anyone who attempts to take away your goods from you. And there is modern authority for saying that force may even be used to recapture your goods, after they have been actually taken out of your possession. But this alleged right to use force, not merely to protect an existing possession but to create one, is not beyond doubt. In the case of real property it certainly does not exist. '

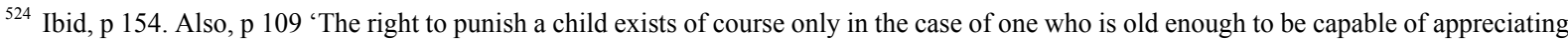
correction; not, for instance, in that of an infant of the age of two and a half [citing $R v$ Griffin (1869) 11 Cox CC 402 (an infant of that age was not capable of appreciating correction. Held manslaughter]. And, in all cases, the character and amount of the punishment that can be recognized as lawful will vary with the age and the sex and the apparent physical condition of the child. But where the punishment has clearly a lawful occasion, and it is not unreasonable in the manner of its infliction or even in its amount, the fact that the child has died in consequence 
- Legal Justification. Assault and battery in furtherance of public authority was justifiable, as in preventing a breach of the peace or arresting a felon or executing any process issued by a court of law;

- Consent. Consent was a defence unless the force was a breach of the peace or causelessly dangerous. ${ }^{526}$ Violenti non fit injuria. Hence, seduction was no assault, either in the law of crime or tort. ${ }^{527}$ However, even the most complete consent was insufficient to legalise an assault when there were public grounds for prohibiting the same. ${ }^{528}$

Kenny also excluded the trifling degree of force involved in petty instances of contact which inevitably arose in the ordinary social intercourse of everyday life, ${ }^{529}$ such as tapping a friend's shoulder to attract his attention or jostling past one's neighbour in a crowd. However, to be justifiable, such acts had to be bona fide, and with no 'unusual vehemence. 530

In conclusion, Kenny usefully suggested the extension of one of the defences (the protection of wives, children and servants) to strangers generally (which now applies). Kenny also stated what (it is asserted) was the law on consent in the past - and which should be the law at present:

- No consent can justify an intentional breach of the peace (i.e. a crime). There simply was (and is) no defence;

- Thus, to intentionally injure a person for whatever reason - whether in a game (or during sexual activity) or in an operation (for example, to mutilate a person by cutting off their arm without a therapeutic reason) or by immoderately beating a child is a crime - save where legislation expressly permits the same, such as in the case of tatooing.

\section{Turner (1945), Cross \& Jones (1949), Williams (1957), Smith \& Hogan (1965)}

The major criminal legal texts in the early 20th century were Harris (the last edition was in 1973), Russell and Kenny. The first (Harris) added little to what was previously stated. ${ }^{531}$ and the last editions of Russell (in 1964) and Kenny (in 1966) are considered later (see 26). As to other works:

\section{(a) Turner (1945)}

\footnotetext{
of it, will not render the parent or master who inflicted it guilty of a felonious homicide. Such a death may ensue where the child has some hidden peculiarity of structure...'

${ }^{525}$ Kenny, n 44, p 154, noted 'This has been sufficiently considered in discussing the subject of homicide.'

526 Ibid. See also p 110.

${ }^{527}$ Kenny, n 44, p 157 cited Pollock on Torts $\left(6^{\text {th }}\right.$ ed, 1901), p 226. Kenny continued 'But the consent must be given freely (i.e. without force, fear or fraud), and by a sane and sober person, so situated as to be able to form a reasonable opinion upon the matter to which consent is given. For 'fraud vitiates consent'; and accordingly an imposter who, by pretending to be a surgeon, induces an invalid to submit to be operated upon by him, will be guilty of assault, notwithstanding the consent which was nominally given.'

${ }^{528}$ Ibid, p 157 'Thus, consent is no defence for any assault that amounts to a breach of the peace; a principle that establishes the illegality of prize fights. The interests of the State similarly preclude the consent of the person injured from affording any defence where the violence exercised (and consented to) involved some extreme and causeless injury to life, limb, or health. If, therefore, one of the parties to a duel is injured, his consent is no excuse [citing Barronet (1852) Dears 51 (169 ER 633) (acted as seconds in a duel in which a man was killed. Committed on a charge of murder, although being foreigners, they did not know duelling was unlawful]. Yet it is uncertain at what degree of danger the law thus takes away a man's right to consent to be placed in situations of peril (as for instance, by allowing himself to be wheeled in a barrow along a tightrope).' [citing Stephen, Digest, see n 42]. But in the case of a surgical operation carried out by a competent surgeon, however great be the risk, there will usually be adequate cause for running it; and so the patient's consent will be full justification for what would otherwise be an aggravated assault. And even injuries which are occasioned in the course of a mere game, if it be a lawful one and be played with due care, are not regarded as causeless.' Kenny cited $R v$ Coney (1882) 8QBD 534, 539 per Cave J, 'a blow struck in anger, or which is likely or intended to do corporal hurt, is an assault, but that a blow struck in sport, and not likely, nor intended to cause bodily harm, is not an assault, and that, an assault being a breach of the peace and unlawful, the consent of the person struck is immaterial.' This case concerned a prize fight.

${ }^{529}$ Kenny referred to Hopper $v$ Reeve (1817) 7 Taunt 698 (129 ER 278)(trespass to drive a carriage against another, injuring a passenger in the latter even if they did not own the same). Per Gibbs CJ at p 700 'he who throws over a chair or a carriage in which another person is sitting, commits a direct trespass against the person of him who is sitting in that carriage or chair.' See also Trindade, n 319 , p 217.

${ }^{530}$ Kenny, n 44, p 156.

531 See e.g. Harris, n 41 (1950 ed), pp 273-4 'An assault is constituted by any attempt to apply unlawful force to another or any threat which is accompanied by or consists of any act or gesture showing a present intention to use unlawful force, and is also accompanied by 'a present ability to carry the threat into execution.' He cited Read v Coker (see n 547). Also, 'A battery includes every touching and laying hold (however trifling) of another's person or clothes in an angry, revengeful, rude, insolent, or hostile manner', or even an act such as striking a horse on which a man is riding so that he is thrown.' He cited Archbold.
} 
Turner wrote a useful article on Assault at Common Law in $1945 .{ }^{532}$ Instead of simply citing Hawkins, ${ }^{533}$ he noted, as to definitions of assault provided by Hawkins, Archbold, Russell, Halsbury and Kenny 'Not only do these definitions lack precision but they also do not coincide with one another in substance. ${ }^{, 54}$ Turner then went on to analyse the actus reus, and the mens rea, of assault.

- Turner submitted that: 'the actus reus of assault was 'causing the person threatened to believe that unlawful force is about to be applied to him by the wrongdoer, i.e. causing a state of mind in the victim'; 535

- As to mens rea, Turner stated that it: 'is merely the realization in the mind of the wrongdoer that his conduct will produce the necessary impression on the mind of the victim. He must, in other words, either intend to alarm the victim, or (it is submitted) intend to do something which he realizes may cause such alarm.' 536

In conclusion, Turner offered his definition of assault:

It is an assault at common law when any person intentionally, or recklessly, by active conduct threatens to apply unlawful physical force to the person of another in such a manner as to create in the mind of that other a belief that such force is about to be so applied. (italics)

This definition of assault by Turner is useful in a number of respects. A review of the history of the offences of assault and battery (from the $6^{\text {th }}$ century) until Turner in 1945 evidences that, by the latter, writers (and the courts) were beginning to come to the conclusion that assault and battery (and wounding) could be committed in four ways: 537

- Intentionally (criminal);

- Recklessly (criminal);

- Negligently (civil);

- Accidently (civil).

Turner reflected this state of judicial analysis, by expressly using the words 'intentionally or recklessly'. In such fashion, he rendered prior definitions of assault (and battery) out of date.

- It is noteworthy that - after Turner - subsequent writers adopted a similar approach. They also concentrated on analyzing the actus reus and mens rea of assault and battery - and reflected their elements in their own definitions;

- Turner also noted in his definition of assault that there must be 'active conduct' and that omission was not sufficient. Also, that the act must be 'unlawful' in that there must be no legal justification for the same.

\section{(b) Cross \& Jones (1949)}

Cross and Jones, in their Introduction to Criminal Law (in 1949), ${ }^{538}$ stated:

An assault is the intentional display of unlawful physical force by one person against another in such circumstances as to create in the mind of such other person the belief that such physical force is about to be used. A battery is the intentional use of unlawful physical force by one person against another. ${ }^{539}$

\footnotetext{
532 Turner, Assault at Common Law, in PH Winfield, The Modern approach to Criminal Law (Macmillan, 1945$)$, ch 18.

${ }^{533}$ Ibid. p 344 'The student who seeks to discover the essential elements of the crime of assault at common law as distinct from battery does not receive much help from the standard text books. Most of them in substance follow the description of assault given by Hawkins 'An assault is an attempt to offer, with force and violence, to do corporal hurt to another.'

${ }^{534}$ Ibid, pp 347-8. For example, Turner questioned as to why there was a distinction between 'attempt' and 'offer' in the definition of Hawkins and that Archbold had omitted the latter word. See also n 260.

${ }^{535}$ Ibid, p 346. Turner also stated, p 348, 'the actus reus in assault consists in creating the expectation in the mind of the victim that unlawful force is about to be applied to him. If this is so, it does not matter whether or not the assailant intends to inflict such force, or can inflict it. It will, however, be no assault if the person threatened does not apprehend that the force will be inflicted either because he may think it impossible (e.g. he may know or believe that he is out of reach or that a weapon is unloaded) or because he does not know that he is being threatened (e.g. he may be asleep, or a newly born baby or his assailant may be secretly approaching from behind). The suggested tests of attempting, or of intending to inflict violence are not true and exclusive tests.'

536 Ibid, p 351.

537 The same applies to murder.

538 Cross \& Jones, n 45.

539 Ibid, p 234. Cross \& Jones noted: 'A person can be guilty of an assault although he does not touch the person assailed, and a man has been convicted of an assault for shaking his fist at another in a threatening manner although he did not touch him [citing Stephens $v$ Myers, see $\mathrm{n}$ 509].
} 
These definitions may be criticised in that they do not cover recklessness. ${ }^{540}$ Cross and Jones had little else to say about these offences save that consent was often a defence, but that it could not excuse an unlawful act. ${ }^{541}$ Also, that - even if there was no consent - the accused might still have a defence. ${ }^{542}$

\section{(c) Williams (1957)}

In a short article in $1957,{ }^{543}$ Glanville Williams considered the nature of threats as assault. He defined assault as follows:

An assault in the strict sense, as opposed to a battery, may be defined as any conduct creating the apprehension of immediate force (e.g. a menacing gesture), provided that, to constitute a crime, there must be the requisite mens rea. ${ }^{544}$

Williams noted that:

- the operative word was 'immediate' - gestures which merely conveyed a threat to commit a battery in the future were not an assault; ${ }^{545}$

- menacing conduct was an assault if it created an apprehension before re-assuring words were uttered; ${ }^{546}$

- a threat to cause serious harm to a trespasser if he did not leave was an assault. ${ }^{547}$

As to whether words alone could constitute an assault, Williams noted:

It is stated in nearly all the books on criminal law and the law of tort that words cannot make an assault. The judicial authority for this supposed rule is of the slightest: little more than a direction to the jury in Meade (1923). ${ }^{548}$

If he touched him he would have been guilty of a battery.' The gist of the offence of assault is the creation of a fear in the mind of the person assailed that unlawful force is about to be used against him. The pointing of an unloaded gun by one person at another may therefore amount to an assault [they refer to St George, see n 491 and to James (see n 510)], but the threatening gesture may be accompanied by words indicating that there is no intention to carry it out as in the old case of Turbervell v Savage [see 14]... If the circumstances are such that there cannot possibly be any fear that the threat will be carried out as where a person on a rapidly moving train shakes his fist at someone who is standing on the platform, an assault is not committed.'

${ }^{540}$ Cross and Jones did exclude 'accidental' assault and battery. At p 235 'On general principles, a mere accidental contact, such as jostling in a queue or a collision on the pavement, is, while technically a battery, not punishable as such on the ground that it was an accident.' Cross and Jones cited Ackroyd v Barett (1894) 11 TLR 115 (a bicyclist who, when riding furiously and recklessly, knocks down and injures another unintentionally cannot be convicted of an assault. No intention). However, today, this position might be different if the person was reckless.

${ }^{541} R v$ Donovan [1934] 2 KB 498. The accused was charged with an assault on a women to gratify a sexual impulse (caning her). It was held that consent was not a defence if the blows were likely to cause grievous bodily harm. Swift J, p 509 stated that the jury should have been directed that it was a battery if 'they were satisfied that the blows struck by the prisoner were likely or intended to do bodily harm to the prosecutrix.' Cross and Jones added that 'if a lawful game is being played according to the rules, a technical assault by one participant upon another is not punishable because the game is in itself lawful and all the players, by joining in on the basis of the rules, must be assumed to have accepted the risk of being assaulted. It is otherwise if the contest is one which is unlawful in itself e.g. a prize fight or duel. It may sometimes happen that a player will be guilty of battery, although he keeps to the rules, if he uses an unreasonable and unjustified amount of physical force upon another participant.' See also Williams, n 575, p 155.

${ }^{542}$ Cross and Jones, n 45, p 236 added 'Parents and schoolmasters have the right to inflict reasonable punishment upon children, but if the amount or nature of the punishment are unreasonable, the battery will be punishable. Again, a man may use a reasonable amount of force in defending himself or his family or in ejecting a trespasser from his property, but if the force used is unreasonable in the circumstances or is applied for the purposes of revenge, the battery is punishable.' Cross and Jones cited R v Driscoll (1841) Car \& M 214 (174 ER 477) per Coleridge $\mathrm{J}$, at p 214 'If one man strikes another a blow, that other has the right to defend himself: and if, when all danger is past, he strikes a blow not necessary for his defence, he commits an assault and battery.'

${ }^{543}$ Williams, Assault and Words [1957] Crim LR 219.

544 Ibid.

545 Ibid.

546 Ibid, p 220.

${ }^{547}$ He cited Read v Coker (1853) 13 CB 850 (138 ER 1437)(D, the occupier of premises, told P to leave. On his failure to do so, D collected some men, who mustered around P, tucking up their sleeves and threatening to break his neck if he did not leave. P seeing they would carry out the threat, departed. D was held liable for assault. It was held that P became a trespasser on his failure to leave - but it would not have been lawful to break his neck or inflict other serious harm on him or to use any force on him except that which was necessary for his ejection. Threats that went beyond that, constituted an assault. Per Jervis CJ at p 860, there was an assault since there was 'a threat of violence exhibiting an intention to assault, and a present ability to carry the threat into execution.' See also Osborn v Veitch (1858) 1 F \& F 317 (175 ER 744$)$ (a threat to shoot a person, coupled with the act of presenting a loaded firearm at him, although it was at half-cock, was an assault). See also Street, $\mathrm{n} 163$, pp 11-2.

${ }^{548}$ Mead's \& Belt's Case (1823) 1 Lew 185 (168 ER 1006) per Holroyd J at p 185 'no words or singing are equivalent to an assault.' In the case troublemakers surrounded his house, singing songs. He fired from it and killed one. See also Trindade, n 319 , p 231. 
Williams considered that a verbal threat of immediate force had all the essential elements of an assault (particularly when it was uttered with the intention of imposing a present restraint on the conduct of the victim, and that there was nothing contrary to this view).

- Williams noted that, in the medieval period, there was a common law action of menacing and that 'menaces' meant threats of immediate injury - whether coupled with a condition or not. He noted that this had not only failed to make an entry in the modern works on tort and crime but that it was not even noticed in the legal histories. There was, however, no reason to suppose that it could not be successfully revived; 549

- In support of this, Williams referred to a case in 1353 (see 9(a)) but noted that it 'concerned the king, which might have made a difference. ${ }^{550}$ Williams also referred to a case in 1476 concerning threats (menaces) referred to by Brooke (in 1586) and Fitzherbert (in 1577) in their abridgments. ${ }^{551}$

One would agree with Williams. Indeed, it may be noted, that a threat could be an assault in early times and this was asserted by legal writers until Hawkins (in 1716) who - without good reason (it seems) - excluded them (see 15(a)) with later writers following his stance. Today, however, it would seem better to exclude threats (when not accompanied by an act) from assault and, instead, treat them as a form of harassment.

\section{(d) Smith \& Hogan (1965)}

Smith and Hogan, in the first edition of their Criminal Law (1965), had a chapter on assault and battery ${ }^{552}$ in which they analysed the actus reus and mens rea of the same. They stated, as to a definition of assault:

An assault is any act which D, intentionally or (possibly) recklessly, causes $\mathrm{P}$ to apprehend immediate and unlawful personal violence. A battery is an act by which $\mathrm{D}$, intentionally or (possibly) recklessly, inflicts unlawful personal violence upon P. ${ }^{553}$ An assault is often described as an attempt to commit a battery ${ }^{554}$ or other crime of personal violence; but this is too narrow, for an assault may be committed where D has no intention to carry out a battery. ${ }^{555}$

As to the actus reus and mens rea of assault and battery, Smith and Hogan noted as follows:

- $\quad$ Assault. There had to be some act done by D (it was difficult to envisage an assault done by omission). ${ }^{556}$ Further, there was no assault: (a) if the act was unobserved by $\mathrm{P}^{557}$ or (b) D was unable to carry out his threat; ${ }^{558}$ or (c) the threat was a future (as opposed to a present) one. ${ }^{559}$ As to mens rea, Smith

\footnotetext{
${ }^{549}$ Williams, n 543, p 224.

550 Ibid, p 225.

${ }^{551}$ Brooke, n 19 (Trespass, pl 388) and Fitzherbert, n 18 (Trespass, pl 143). See 16 Edw 4 p 11 fo 7b (1476, Seipp no 1476.029). Seipp cites ‘
}

Brooke Trespas 388, fol. 299r: Trespas de manasse le defendant dit que le pleintiff fuit indet a luy, et il dit a luy, que il voet suer pur ceo per le ley, et luy imprison s il poet, que est mesme le manas; Et per opinio Curia, ceo n est ple, car 1 un est tortious manas, et 1 auter est loyal manas (in Trespass for threatening, the defendant pleads that the plaintiff was indebted to him (defendant), and he (defendant creditor) said to him (plaintiff debtor) that he (defendant creditor) would sue (plaintiff debtor) for this (debt) by the law, and (defendant creditor would) imprison him (plaintiff debtor) if he (defendant creditor) could, which was the same threat; and by the opinion of the Court, this is no plea, because the one (trespass of which plaintiff counted) was a wrongful threat (tortious manas), and the other (threat of which defendant pleaded) was a lawful threat (loyal manas).' See also Comyns, n 26 (1792 ed), p 131 'So trespass lies if a man threaten another with his life and members... or threaten to pull down his house... or if he says, that he will cut off his arm...That if he call him a traitor, he will defend himself upon his body, and kill rather than he will be killed...or will defend himself during the life of one of them...so if he says, that if he will come out of church etc. and speak so, he will beat him etc...so if he threaten a battery, unless he cease a suit against him.' Comyns cited Rolle, $\mathrm{n} 21$, p 545 which cited cases in 1458 (37 Hen 6 pl 4, fo 2b-3b. Seipp no 1458.039) and 1459 (37 Hen 6 pl 8 fo 19b-21a. Seipp no 1459.015). For a threat of forcible ejectment, see Ansell v Thomas \& Another [1974] Crim LR 31.

552 They referred to Turner, Assault at Common Law MACL 344 (see 28(a)) and to Williams, see n 543.

${ }^{553}$ Rolfe (1952) 36 Cr App R 4 (an indecent assault). Goddard CJ, p 6 'An assault can be committed without touching a person. One always thinks of an assault as the giving of a blow to somebody, but that is not necessary. An assault may be constituted by a threat or a hostile act committed towards a person, and if a man indecently exposes himself and walks towards a woman with his person exposed and makes an indecent suggestion to her that, in the opinion of the court, can amount to an assault.'

${ }^{554}$ For 'attempt' and 'offer' see n 260.

${ }^{555}$ Smith \& Hogan, n 46, p 262. they also stated: 'Assault is an independent crime and should be treated as such. It should be noted that assault and battery are also torts; and many, though not all, of the principles appear to be equally applicable in both branches of the law.'

${ }^{556}$ One would agree. All prior examples from Hawkins (1716-21) refer to positive acts. Smith \& Hogan also considered whether words could amount to an assault. Ibid, pp 263-4.

${ }^{557}$ Smith \& Hogan, n 46, p 262 'as where D approaches P from behind, or P is asleep or insensible or too young to appreciate what D appears likely to do.' See also Trindade, n 319, p 235.

${ }^{558}$ Ibid, 'there can be no assault if it is obvious to $\mathrm{P}$ that $\mathrm{D}$ is unable to carry out his threat, as where D shakes his fist at $\mathrm{P}$ who is safely locked inside his car.' As to D pointing an unloaded gun at $\mathrm{P}$ 'If $\mathrm{P}$ knows the gun is unloaded, there is no assault, for then he could not be put in fear. If 
and Hogan noted that the cases generally referred to the necessity of an intention in assault ${ }^{560}$ but that they thought recklessness should also be included ${ }^{561}$ - but not negligence. ${ }^{562}$ They did not think a 'hostile' intention was necessary. ${ }^{563}$ Nor that an attempt to commit an assault was a crime, ${ }^{.64}$

- Battery. Smith and Hogan indicated that this consisted in the infliction of unlawful personal violence by $\mathrm{D}$ on $\mathrm{P}^{565}$ or the clothes he was wearing. ${ }^{566}$ The violence did not need to be direct. ${ }^{567}$ While noting the civil offence of battery might be applied intentionally, recklessly or negligently, they were uncertain as to the latter two in the criminal context - although there seemed cause to consider recklessness in the criminal context. ${ }^{568}$

As noted later, one would assert that assault and battery in the criminal context should cover only intentional and reckless conduct (leaving negligent and accidental conduct to the civil sphere). One would agree with Smith \& Hogan that:

P believes the gun is, or may be loaded, there is an actus reus, for now he suffers the apprehension which is an essential element of the crime.' One would agree. It is the apprehension (belief) of $P$ that $D$ is about to inflict a battery on him which is the conduct which should be the relevant factor - whether or not (in fact) D can do it (unless P knows that D cannot do it). See also Logdon v DPP [1976] Crim LR 121 (Guilty of assault when he held a VAT inspector hostage and showed her a pistol which he said was loaded (although it was a replica and not loaded).

${ }^{559} \mathrm{Ibid}, \mathrm{p} 263$ 'It is clear that a threat to inflict harm at some time in the future cannot amount to an assault - an apprehension of immediate personal violence is essential.' They cited Stephens $v$ Myers (see n 509).

${ }^{560} \mathrm{Ibid}, \mathrm{p} 264$ 'In the earlier authorities, where assault was described as an attempt to inflict violence it was consistent to hold that nothing less than an intention to inflict it would do. According to the modern view, however, it would be an assault if $\mathrm{D}$ struck in the direction of $\mathrm{P}$, intending only to alarm him and not to touch him; but it could not be an attempted battery.'

${ }^{561}$ Ibid, p 264 'It is submitted that it would be in accordance with principle to hold D guilty if he were merely reckless whether P might not be alarmed by his gesture.' Cf. Cunningham [1957] 2 QB 396 (A stole a gas meter from a house, fracturing a pipe with the result that gas seeped into an adjoining house and was inhaled by $\mathrm{W}$ who was asleep. A was prosecuted under the OPA, $\mathrm{s} 23$ (unlawfully and maliciously causing W to take a noxious thing, so as to endanger her life)). The court treated 'maliciously' the same as recklessly (following Kenny, n 44 , (16 ${ }^{\text {th }}$ ed, 1952), p 186).

${ }^{562}$ Ibid. 'It may be although there is no authority on the point, that a civil action will lie for a negligent assault; but, in principle, it should not be a crime.' Smith \& Hogan cited H Street, The Law of Torts ( $3^{\text {rd }}$ ed, 1963), p 20.

${ }^{563}$ Ibid.' It is often said that D must have had a hostile intention in assault and battery. So far as assault is concerned, this adds nothing to intentionally and recklessly causing apprehension. It would be no defence that D was friendly with P and did it for a joke - unless P's consent could be implied.' They referred to Coward v Baddeley (1859) 4 H \& N 478 (157 ER 927)(a person cannot justify giving another into custody for merely laying hands on him to attract his attention, provided it is not done hostilely), per Martin, $\mathrm{p} 481$ 'Touching a person so as merely to call his attention, whether the subject of a civil action or not, is not the ground of criminal proceedings.' They also referred to Fairclough $v$ Whipp [1951] 2 AE 834 (a case relating to an asserted indecent assault under the OPA 1861, s 52, where Goddard CJ stated, p 834 'I do not know any authority which says that where one person invites another person to touch him that can be said to be an assault.'). See also DPP $v$ Rogers [1963] 2 AE 644 (sexual behaviour between man and consenting daughter) and Beal $v$ Kelley [1951] 2AE 763 (indecent assault on a boy under 16 under OPA 1861, s 62, per Goddard CJ p 764 'assault - a hostile act because it was done against the boy's will. It does not matter that the boy could not give consent.'). See also Christopherson v Bere (1848) 11 QB 477 (116 ER 556) per Patteson J at p 477 'An assault must be an act done against the will of the party assaulted: and therefore it cannot be said that a party has been assaulted by his own permission.'

${ }^{564} \mathrm{Ibid}$ 'It has been questioned whether there can be an attempt to assault, since assault itself was regarded as an attempt to commit a battery. It is submitted that, since assault itself is now wider than attempted battery, there is no reason why there should not be attempt to commit it; as where $\mathrm{D}$ points an unloaded gun at $\mathrm{P}$, intending to frighten him, but $\mathrm{P}$, knowing the gun is unloaded, is unperturbed.'

${ }^{565}$ At p 265 'It used to be said that every battery involves an assault; but this is plainly not so, for in battery there need be no apprehension of the impending violence. A blow from behind is not any less a battery because $\mathrm{P}$ was unaware that it was coming.'

${ }^{566}$ Ibid. 'For this purpose the person of the victim includes the clothes he is wearing; Parke B ruled that there was a common assault where D slashed P's clothes with a knife: [the cited Day, see n 492]. Presumably in this example, however, it is necessary that the blow be felt by P, for there is no injury to his clothes.'

${ }^{567}$ Ibid. 'Most batteries are directly inflicted, as by D's striking P with his fist or an instrument, or by a missile thrown at him, or by spitting upon P. But it is not essential that the violence should have been so directly inflicted. Thus Stephen and Wills JJ thought that there would be a battery where D digs a pit for P to fall into, or, as in Martin [1881 8 QBD 54 ] he causes P to rush into an obstruction. It would undoubtedly be a battery to set a dog onto another. [they cited Plunkett v Mitchell [1958] Crim LR 252]. If D beat O's horse causing it to run down P, this would be a battery by D. [they cited Gibbons v Pepper, see 14]. No doubt the famous civil case of Scott $v$ Shepherd [see 18] is equally good for the criminal law. D throws a squib into a market house. First $\mathrm{E}$ and then $\mathrm{F}$ flings the squib away in order to save himself from injury. It explodes and injures P. This is battery by D.' In Plunkett v Mitchell, the D's guard dog sprang at a person, gripping his wrist and tearing his clothing but not injuring him. Self defence was pleaded. It was held the use of the dog was not reasonable in the circumstances. M was convicted and discharged absolutely. In Martin, with the intention of causing terror in the minds of persons leaving a theatre, put out the gaslights on a staircase where a large number of people had to descend, in order to leave the theatre. Also, with the intention of obstructing the exit, he placed an iron bar across the doorway through which they had to leave. People panicked on leaving and a number injured themselves. M was held guilty of unlawfully and maliciously inflicting GBH on A and B pursuant to the OPA, s 20. Per Coleridge CJ at $\mathrm{p} 58$ 'He acted 'unlawfully and maliciously', not that he had any personal motive against the particular individuals injured, but in the sense of doing an unlawful act calculated to injure, and by which others were in fact injured.'

${ }^{568}$ At p 266 'It may look odd to convict reckless road users of battery; but, if they are reckless whether they cause personal injury, why not?' 
- a 'hostile' intention is not necessary (since 'hostile' adds nothing);

- $\quad$ an attempt to assault should not be a crime.

Also, that an assault is not committed if:

- the threat is only a future one;

- the threat is unobserved by the 'victim' (contra, if a battery);

- $\quad \mathrm{D}$ is unable to carry out his threat and $\mathrm{P}$ knows this.

However, if there is a reasonable apprehension (belief) of $\mathrm{P}$ that $\mathrm{D}$ will carry out his threat (whether D can or not), one would assert that this is sufficient for assault.

\section{(e) Defences}

- $\quad$ Self Defence \& Defending Others. Smith \& Hogan noted that, since self-defence might afford a defence to murder, 'obviously it might do so for lesser offences against the person and subject to similar conditions'. However, it should be proportionate; ${ }^{.69}$

- Lawful Correction. Smith \& Hogan noted that parents were entitled to inflict moderate and reasonable chastisement on their children and that school teachers 'are in the same position as parents with regard to the conduct of the child at, or on its way to or from school. ${ }^{570}$ They also noted 'The ancient right to chastise a wife, a servant or an apprentice may now be regarded as obsolete.'; 571

- Consent. Smith and Hogan indicated that the essence of assault and battery were that 'they are done against the will of the victim. Consent therefore negatives either crime and the onus of proving the absence of consent is on the Crown.' 572 They noted that fraud did not necessarily negative consent. It did so only if $\mathrm{P}$ was deceived as to the substance of the act done. ${ }^{573}$ Consent might be negatived by duress and submission was not consent. ${ }^{574}$ Further, Smith and Hogan noted that there were limits to the degree of physical harm that might be inflicted by consent, ${ }^{575}$ such as in prize fights. ${ }^{576}$ And that, in sports, a person could not consent to acts which were likely to cause him death or serious injury (and the rules of any sport so permitting would be irrelevant). ${ }^{577}$ Further, that there were public policy considerations involved. ${ }^{578}$

\footnotetext{
${ }^{569} \mathrm{Ibid}$, pp 269-70 'An attack which would not justify D in killing might justify him in the use of some less degree of force, and so afford a defence to a charge of wounding, or, a fortiori, common assault. But the use of greater force than is necessary to repel the attack will result in liability to conviction for common assault, or whatever offence the degree of harm caused and intended warrants.' They referred to Driscoll (see $\mathrm{n}$ 542). See also $R v$ Morse (1910) Cr App R 50 (prosecutor attacked appellant with fists who then twice struck him on the head with a razor. Held unnecessary violence to use a razor in self-defence against an unarmed assailant).

${ }^{570}$ At $\mathrm{p} 269$.

571 Ibid.

${ }^{572}$ Smith \& Hogan cited Donovan (see n 541).

${ }^{573}$ Smith \& Hogan referred to Clarence (1888) 22 QBD 23 (prisoner gave a sexual disease to his wife. No offence within OPA 1861 , ss 20 \& 27). Cf. Dica [2004] 3 WLR 213 and Konzani [2005] EWCA Crim 706.

${ }^{574}$ At p 267 'Consent may also be negatived by duress which may be implied from the relationship between the parties - for example where D is acting as schoolmaster, and P a thirteen-year-old pupil. [cited Nichol, see n 471]. As in rape and indecent assault, submission is not consent. But an unfounded belief in P's consent ought to afford a defence, at least if it is reasonable, and, in principle, even if it is not.'

575 They cited an article by G Williams, Consent and Public Policy [1962] Crim LR 74 (in which he considered duels, prize fights, unregulated fights, consent in games, sexual activity and surgical operations).

${ }^{576}$ Ibid 'It is clear that there are limits to the degree of physical harm to which a person can effectively consent but where the line is to be drawn is by no means clear. To take the most obvious example, it is no defence on a charge of murder for $\mathrm{D}$ to say that $\mathrm{P}$ asked to be killed. 'Prize fights' have long been held to be batteries. It seems that 'prize fight' in this context signifies a fight without gloves, or otherwise likely to cause more serious injury than boxing under the Queensbury rules.' They cited Coney (see n 528). See also M Foster, Crown Cases ( ${ }^{\text {nd }}$ ed, 1776), pp 260-1 (prize cases). He also referred, p 261, to public jousts and tournaments being prohibited save with special licence of the king, which accords with $\mathrm{n} 151$

577 At p 268. Smith \& Hogan also considered sexual acts citing Donovan (see n 541) as well as surgical operations, see p 268.

${ }^{578}$ Smith \& Hogan referred Wright (1603) mentioned by Coke, n 32, vol 1, 127a \& b (a beggar, to lend colour to his begging and to avoid labour, had a companion strike off his left hand. Coke says 'both of them were indicted, fined and ransomed therefore, and that by the rest of the justices for the cause aforesaid'). Also, 'Maiming, even with consent, was unlawful because it deprived the king of a fighting man. In early Victorian times when soldiers, as part of their drill, had to bite cartridges, a soldier got a dentist to pull out his front teeth to avoid the drill. Stephen J thought that both were guilty of a crime.' Smith \& Hogan cited Stephen (Digest), n 42 ('When it was an essential part of a common soldier's drill to bite cartridges I believe that it was not an uncommon military offence to get his front teeth pulled out, and this would, I presume, be an offence at common law also.'
} 
It is a pity that Smith and Hogan did not commence their discussion of consent by stating the basic principle which has prevailed, vis-à-vis battery from time immemorial, viz. that no consent can justify an intentional breach of the peace (i.e. a crime). And that a breach of the peace was held to have occurred where a person inflicted an injury (other than a minor one) on another person. There simply was no defence. Thus, all prior cases related to where there was no intent to injure (such as in surgery, where it was therapeutic, to heal a wound rather than create one) or where, albeit intentional, it was treated as minor (minor correction of a child or minor injuries sustained in the course of a game or, indeed, in sexual activity - forcefully whipping a person not being treated as minor, even if consensual).

Finally, Smith \& Hogan dealt with 'trivial blows' and noted that:'there is an implied consent to that degree of contact which is necessary or customary in everyday usage. ${ }^{579}$

In conclusion, Smith and Hogan provided one of the first substantive analyses of the actus reus and mens rea of assault and battery and in so doing rendered much of what past legal writers had written (including Hawkins) otiose.

\section{Russell (1964) \& Kenny (1966)}

The final edition of Russell (in 1964) and the final edition of Kenny (in 1966) were both edited by Turner. Thus, there was a considerable degree of commonality and it is useful to discuss both at the same time (I refer to the 1964 edition of Russell and add material in respect of the final edition of Kenny in 1966 in the footnotes since the commentary in the latter was much shorter and added little to the former).

\section{(a) Assault}

Russell stated:

An assault, as distinct from battery, is a threat by one man to inflict unlawful force (whether light or heavy) upon another; it constitutes a crime at common law when the threatener, by some physical act, has intentionally caused the other to believe that such force is about to be inflicted upon him. ${ }^{580}$

The actus reus of assault thus consists in the expectation of physical contact which the offender creates in the mind of the person whom he threatens. The mens rea consists in the realisation by his offender that his demeanour will produce that expectation. ${ }^{581}$

Turner noted that assault was constituted notwithstanding the threatener did not intend to apply the threatened force. Further, the anticipated contact did not need not be dangerous - a threat to kiss (or stroke) a person unlawfully was enough. ${ }^{582}$ Thus, to hold up a hand against another in threatening manner and say nothing was an assault. Also, 'it would seem that the common law principle of assault would include a threat unlawfully to project a light, heat, electrical energy, gas, odour or any other thing on to the person of another. ${ }^{583}$ Turner also noted the following:

- the threat had to be a present (and not a future) one; ${ }^{584}$

- $\quad$ inability to carry out the threat was no defence, if the person threatened did not know it; ${ }^{585}$

\footnotetext{
${ }^{579}$ Ibid, p 265 'Violence' here includes the smallest degree of personal contact - a mere touching without consent is enough. But there is an implied consent to that degree of contact which is necessary or customary in everyday usage. In Tuberville $v$ Savage [see 14] it was said that it was no assault to strike another on the hand, arm or breast in ordinary discourse. Touching another to attract his attention is not a battery, even as if, in Coward v Baddeley [see n 563], P has already told D to go away and mind his own business. In Coward v Baddeley, the court put its decision on the ground of lack of hostility, but there are difficulties in requiring the act to be hostile, and not only in indecent assaults. If $\mathrm{D}$, out of concern for P's morals, were to drag P away to prevent him watching an indecent exhibition, this would surely be a battery; but would it be 'hostile.'?'

${ }^{580}$ Russell, n 38, vol 1, p 652 also refers to 'recklessly' in a footnote. Cf. Kenny, n 44 (1966 ed Turner), p 217 'Assault [is] a threat to inflict unlawful force (however slight or great) upon another man.'

${ }^{581}$ Russell (ed Turner, 1964), n 38, vol 1, p 652. Cf. Kenny, n 44 (1966 ed Turner), p 217 'The actus reus of the crime at common law is constituted when the threatener has made some movement which has caused the other person to believe that this unlawful physical contact is imminent, In other words the actus reus consists of the effect on the victim's mind which the threat creates.' Also, 'The mens rea is constituted by the threatener's intention to produce that expectation in the victim's mind. It is thus irrelevant that the threatener had no intention to inflict, or even no ability to inflict, the contact which he had induced the victim to expect.' Russell cited Beal v Kelley, Fairclough $v$ Whipp and DPP $v$ Rogers (see n 563).

${ }^{582}$ Kenny, n 44 (ed Turner), vol 1, p 652.

${ }^{583}$ Ibid, pp 652-3 referring to Queensland Criminal Code 1899.

${ }^{584}$ Ibid, p 652 'So drawing a sword or bayonet, or presenting a gun at a person who is within reach, or any similar act, in such circumstances as suggest an intention, coupled with an actual or apparent present ability to apply actual force to the person of another will amount to an assault provided that other is caused to believe that the force is about to be so applied.'
} 
- there was no assault if the person threatened did not know it; ${ }^{586}$

- there was no assault if person threatened knew the threat could not be carried out. ${ }^{587}$

\section{(b) Battery}

Russell stated:

A battery consists in the actual application of unlawful force to another person, but any force whatsoever, be it ever so small, being actually applied to the person of a man adversely (i.e. without his consent) in an angry or revengeful, or rude or insolent manner, such as spitting in his face, or in any way touching him in anger, or violently jostling him out of the way, or throwing water over him, is a battery in law. ${ }^{588}$

Russell noted that - as with assault - the battery must be intentional or reckless. ${ }^{59}$ It need not be effected by the hand of the party accused ${ }^{590}$ or be direct. ${ }^{591}$ Also, that it was untrue to say that every battery included an assault. ${ }^{592}$

\section{(c) Defences}

Russell considered the same defences as in the first edition (in 1819), viz:

- Self Defence, Defending Others \& Property. Russell stated: 'The use of force is lawful for the necessary defence of self or others ${ }^{593}$ or of property; ${ }^{594}$ but the justification is limited by the necessity of the occasion, and the use of unnecessary force is an assault';

- Lawful Correction. 'A parent may chastise his child, a schoolmaster his pupil and a master his apprentice, if the chastisement is moderate in the manner, the instrument and the quality and the child is old enough to appreciate correction.'; 595

- $\quad$ Legal Justification. 'there are circumstances in which force may lawfully be applied to one who does not consent e.g. where the force is used in the due execution of the law. ${ }^{, 596}$

\footnotetext{
${ }^{585} \mathrm{Ibid}, \mathrm{p} 653$ 'As the gist of the crime lies in the effect which the threat creates upon the mind of the victim it is plain that on principle it can make no difference if the threatener in fact is quite unable to carry out the threat, provide the victim does not know this, but believes that the threat is about to be implemented. Therefore, if a person presents a pistol, purporting to be a loaded pistol, at another who is within range and who is caused to believe that it is about to be fired at him, it is an assault in point of law, although in fact the pistol is unloaded.'

${ }^{586}$ Ibid, p 655 'for example, if he were asleep or did not see the other party advancing upon him.'

${ }^{587}$ Ibid 'nor can there be an assault if the person threatened knows that the threat cannot be carried out, for example, if he knows that a pistol which is aimed at him is not loaded. And this will be so even if the other party mistakenly believes that the pistol is loaded.'

${ }^{588}$ Ibid, p 655. Cf. Kenny (1966, ed Turner), p 218 'A battery consists in the actual application of unlawful force, and it can be committed on a person whether he expects it or not; for example because his back is turned, or he is asleep.'

${ }^{589} \mathrm{Ibid}$ 'As in the crime of assault, so also in the crime of battery, the force complained of must have been intentionally or recklessly applied by the accused, and it must be force which cannot be legally justified.' Russell also noted that cutting a man's clothes when on him was a battery, citing Day (see n 492) but that passive obstruction was not (citing Innes $v$ Wylie, see $\mathrm{n} 480$ ).

${ }^{590}$ Ibid, p 656 (encouraging a dog to bite etc.).

${ }^{591}$ Ibid, p 656 citing Scott $v$ Shepherd (see 18) and Short v Lovejoy (see 18).

${ }^{592} \mathrm{Ibid}, \mathrm{p} 655$ 'Some early authorities stated that every battery included an assault, but it is plain that, at any rate in the subsequent development of the common law, this statement is no longer true, since it is most clearly laid down that some kind of alarm or anticipation by the person assaulted is essential, whereas a battery may be committed secretly and suddenly without any knowledge on the part of the victim that he was about to be struck.' See also Trindade, n 319, p 227 who cited as batteries where a lady is kissed when asleep, a man punched when in a drunken stupor and a person who, while under an anaesthetic, has a different operation performed to one he consented to.

${ }^{593}$ Ibid, p 681 'if a man beats, wounds, or maims one who is making an assault upon his own person, or that of his wife, parent, child or master; or if a man fights with, or beats, one who attempts to kill any stranger; in these cases also it seems that the party may justify the assault and battery, and a wife may justify an assault in defence of her husband.'

${ }^{594}$ Ibid, p 680 'So if A beats B (without wounding him, or throwing at him a dangerous weapon), who is wrongfully endeavouring, with violence, to dispossess him of his lands, or of the goods, either of himself or of any other person, which have been delivered to him to be kept, and will not desist upon A's laying his hands gently upon him and disturbing him.' See also p 682. Russell also cites Driscoll (see n 542), Morse (see n 569) and $R v$ Hussey (1924) 18 Cr App R 160 (Tenant was given notice to quit but rejected it. The landlady and others then attempted to force their way into the property which he had barricaded. The appellant fired on them, wounding two. Hewart CJ cited Archbold, $26^{\text {th }}$ ed (1922), p 887 'In defence of a man's house the owner or his family may kill a trespasser who would forcibly dispossess him of it, in the same manner as he might by law, kill in self-defence a man who attacks him personally; with this distinction, however, that in defending his home he need not retreat, as in other cases of self-defence, for that would be giving up his house to his adversary).'

595 Ibid, p 677.

${ }^{596}$ Ibid, p 657. Russell then considered the duties of JP's and constables in respect of arrest, pp 657-77 (the material is now out of date).
} 
- Consent. 'The use of force against the person of another is not unlawful when he has consented to it; thus it is not battery to lay a hand gently on another without hostile intention, but merely to attract his attention, for men are presumed to consent to such contacts in everyday life, ${ }^{597}$ Russell then considered fraud, games and surgical operations. ${ }^{598}$

Finally, Russell stated: 'Save in special circumstances a victim of assault alone is rarely disposed to initiate a prosecution since he has suffered no actual hurt. ${ }^{599}$ This simple observation was rarely emphasised by prior writers. However, it is important and it re-inforces the point made as long ago as Bracton (see 7) that trivial matters should not be subject to criminal prosecution.

\section{Cases: 1967- 85}

A number of useful cases clarifying various issues in respect of assault and battery occurred in this period. These comprise:

- Kenlin v Gardiner (1967) ${ }^{600}$ Two boys were charged with assaulting a constable contrary to the Police Act 1964, s 51(1). They pleaded justification. It was held this defence was available (as in the case of any other assault) provided the prior assault of the constable was not justified (it was not, since taking the boys' arm was not to arrest them);

- $\quad \underline{\operatorname{Lamb}(\mathbf{1 9 6 7 )}}{ }^{601} \mathrm{D}$ (in jest, and with no intention to harm) pointed a revolver at a friend (who also took it as a jest) and discharged it, killing him. D was charged with manslaughter. The court held that mens rea being an established ingredient, manslaughter could not be established except by proving that element of intent without which there could be no assault. Sachs LJ '[Counsel] rightly conceded that there was no evidence to the jury of any assault of any kind. ${ }^{602}$

- $\quad$ Fagan v MPC (1969) ${ }^{603}$ The accused drove his car towards a police officer and stopped it with the off-side wheel on the latter's foot. James J (who gave judgment for the court) stated 'An assault is any act which intentionally - or possibly recklessly - causes another person to apprehend immediate and unlawful personal violence.' ${ }^{604} \mathrm{He}$ also noted that a battery could be committed indirectly ${ }^{605}$ but not by way of omission. ${ }^{606}$ Further, for the assault to be committed both the actus reus and mens rea must be present at the same time; ${ }^{607}$

- Donnelly v Jackman (1970) ${ }^{608}$ A constable touched the D on the shoulder, intending to stop him in order to speak to him. Held, in so doing, the officer was not acting outside the ambits of his duties, per

\footnotetext{
${ }^{597}$ Ibid, p 657 'the answer, therefore, to any criminal charge which a resentful man might threaten against one who had innocently touched him in a way, would be a reasonable mistake of fact in thinking that the man touched was a consenting party. But if a person has made it plain to the other that he objects to being touched it would thereupon be assault to offer to touch him and a battery to touch him.'

${ }^{598}$ Ibid, pp 678-80 (the material is now out of date).

${ }^{599}$ Kenny, n 44 (1966 ed), p 218.

${ }^{600}$ [1967] 2 QB 510.

${ }^{601}$ [1967] 2 QB 981.

${ }^{602}$ At $\mathrm{p}$ 988. It is asserted that this case (prior to Venna (1975) and the recognition of recklessness) would not be so decided today. Instead, the issue (being in jest) would be whether D was reckless. If so, then a battery (criminal) was committed, since the victim suffered an unlawful injury as a result. If not reckless, if $\mathrm{D}$ was negligent, a battery at civil law was committed.

${ }^{603}$ [1969] 1 QB 439.

${ }^{604}$ Ibid, p 444.

${ }^{605}$ Ibid. 'Where an assault involves a battery, it matters not, in our judgment, whether the battery is inflicted directly by the body of the offender or through the medium of some weapon or instrument controlled by the action of the offender. An assault may be committed by the laying of a hand upon another, and the action does not cease to be an assault if it is a stick held in the hand and not the hand itself which is laid on the person of the victim. So for our part we see no difference in principle between the action of stepping on to a person's toe and maintaining that position and the action of driving a car on to a person's foot and sitting in the car while its position on the foot is maintained.'

${ }^{606}$ Ibid, 'a mere omission to act cannot amount to an assault.' See also Constable of Thames Valley Police [2012] EWCA Civ 1841 per Sedley LJ 'While it is not an assault simply to get in someone's way, it is a technical assault to obstruct them in circumstances which makes it clear that if they go on they will be stopped forcibly.'

${ }^{607}$ Ibid, p 445 'For an assault to be committed, both the elements of actus reus and mens rea must be present at the same time. The 'actus reus' is the action causing the effect on the victim's mind...The 'mens rea' is the intention to cause that effect. It is not necessary that mens rea should be present at the inception of the actus reus; it can be superimposed upon an existing act. On the other hand, the subsequent inception of mens rea cannot convert an act which has been completed without the mens rea into an assault...There was an act constituting a battery which at its inception was not criminal because there was no element of intention but which became criminal from the moment the intention was formed to produce the apprehension which was flowing from the continuing act.'

${ }^{608}$ [1970] 1 WLR 562.
} 
Talbot $\mathrm{J}$ 'one ought to bear in mind that it is not every trivial interference with a citizen's liberty that amounts to a course of conduct sufficient to take the officer out of the course of his duties. '; ${ }^{609}$

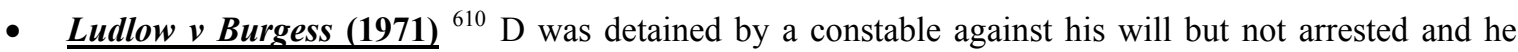
lashed out kicking the constable in the thigh. He was held not guilty of assaulting a police officer under the Police Act 1964, s 51(1) for the act of the constable was outside the execution of his duty;

- Venna (1975) ${ }^{611}$ The court definitively laid it down that battery could be committed recklessly as well as intentionally, James LJ stating: 'We see no reason in logic or in law why a person who recklessly applies physical force to the person of another should be outside the criminal law of assault.' 612

- $\quad$ DPP v Morgan (1976). ${ }^{613}$ Lord Simon stated: 'The actus reus of assault is an act which causes another person to apprehend immediate and unlawful violence. The mens rea corresponds exactly. The prosecution must prove that the accused foresaw that this act would probably cause another person to have apprehension of immediate and unlawful violence, or would probably have that consequence, such being the purpose of the act, or that he was reckless as to whether or not his act caused such apprehension. The foresight (the term of art is 'intention') or recklessness is the mens rea in assault;' 614

- Bentley v Brudzinski (1982) ${ }^{615}$ In a case concerning a constable placing a hand on a person's shoulder without consent and his reaction (swearing and striking the constable in the face), Donaldson LJ stated: ' $I$ hope that police prosecutors will consider making an alternative charge of common assault when they have reason to think that there may be a technical challenge to the officer's authority and when the reaction of the citizen has been wholly unjustifiable. This will enable the limits of an officer's authority to be defined, whilst at the same time doing justice and giving the police officers the support which they are entitled to expect.' 616

- Williams (1983) ${ }^{617}$ Lane CJ stated: 'Assault ...is an act by which the defendant, intentionally or recklessly, applies unlawful force to the complainant.'; 618

- Smith v Chief Superintendent, Woking Police Station (1983) ${ }^{619}$ D entered an enclosed garden at night. Looking through the windows of a ground floor bedsit occupied by an elderly widow, he terrified her and she summoned the police. It was held that $\mathrm{D}$ had intended to frighten his victim and that he did so do. The Court of Appeal cited with approval a definition of Archbold ${ }^{620}$ and held that it was open to JP's to find that his intention was to frighten his victim, in order to cause her to fear some act of immediate violence. The court cited with approval a definition of Archbold. Therefore, there was an assault. Kerr LJ stated: 'it seems to me that they were perfectly entitled to convict the defendant who had gone there, as they found, with the intention of frightening her and causing her to fear some act of immediate violence.'; ${ }^{621}$

\footnotetext{
${ }^{609}$ At p 565 .

61075 Cr App R 227.

${ }^{611}$ [1975] 3 WLR 737 (man being arrested kicked a police officer, fracturing his hand. Charged with, inter alia, common assault).

${ }^{612}$ At p 743. James LJ indicated that $R v$ Bradshaw (1878) 14 Cox CC 83 'can be read as supporting the view that unlawful physical force applied recklessly constitutes a criminal assault.' In Bradshaw it was held that, if while engaged in a friendly game, one of the players committed an unlawful act where death is caused, he was not guilty of manslaughter. Bramwell LJ at pp 84-5 'No rules or practice of any game whatever can make that lawful which is unlawful by the law of the land...But, independent of the rules, if the prisoner intended to cause serious hurt to the deceased, or if he knew that, in charging as he did, he might produce serious injury and was indifferent and reckless as to whether he would produce serious injury or not, then the act would be unlawful.' As to the civil position Trindade, n 319, p 223 (writing in 1992) 'If there is no reason in logic or in law why a person who recklessly applies force to the person of another should be outside the criminal law of assault and battery there is surely no reason in logic or in law why a person who recklessly applies force to the person of another should be outside the civil law of battery (or assault).' (one would agree).

613 1976] AC 182.

${ }^{614}$ At pp 216-7.

61575 Cr App R 217.

${ }^{616}$ At p 226.

${ }^{617}$ (1983) 78 Cr App R 276.

${ }^{618}$ At p 279.

${ }^{619}$ (1983) 76 Cr App R 234.

${ }^{620}$ Archbold, $\mathrm{n} 39$ (41 $\left.{ }^{\text {st }} \mathrm{ed}\right)$, para 20-144 'An assault is any act which intentionally - or recklessly - causes another to apprehend immediate and unlawful violence.'

${ }^{621}$ At $\mathrm{p} 238$.
} 
- Kimber (1983) ${ }^{622}$ Lawton LJ stated: 'An assault is an act by which the D intentionally or recklessly caused the complainant to apprehend immediate, or to sustain, unlawful personal violence. ${ }^{.623}$

- Collins v Wilcock (1984) ${ }^{624}$ Robert Goff LJ stated:' An assault is an act which causes another person to apprehend the infliction of immediate, unlawful, force on his person; a battery is the actual infliction of unlawful force on another person. Both assault and battery are forms of trespass to the person...The fundamental principle, plain and incontestable, is that every person's body is inviolate. It has long been established that any touching of another person, however slight, may amount to a battery... ${ }^{625}$ most of the physical contacts of ordinary life are not actionable because they are impliedly consented to by all who move in society and so expose themselves to the risk of bodily contact. So nobody can complain of the jostling which is inevitable from his presence in, for example, a supermarket, an underground station or a busy street; nor can a person who attends a party complain if his hand is seized in friendship, or even if his back is, within reason, slapped...Although such cases are regarded as examples of implied consent, it is more common nowadays to treat them as falling within a general exception embracing all physical contact which is generally acceptable in the ordinary conduct of daily life. ${ }^{626}$

- Mansfield Justices, ex p Sharkey (1985) ${ }^{627}$ Lane CJ stated: 'An assault is any act by which the defendant intentionally, or recklessly, causes the victim to apprehend immediate unlawful violence. There is no need for it to proceed to physical contact. If it does, it is an assault and a battery.'; ${ }^{628}$

- Wilson v Pringle (1986) ${ }^{629}$ In a civil case of trespass, Croom-Johnson LJ, principally following a dictum of Holt CJ in Cole v Turner (1704, see 14), stated: 'In our view; the authorities lead one to the conclusion that in a battery there must be intentional touching or contact in one form or another of the plaintiff by the defendant. That touching must be proved to be hostile touching.' ${ }^{630}$ The proposition as to hostile touching (it is asserted) is incorrect and was doubted by Lord Goff in $\operatorname{Re} F(1990){ }^{631}$

\section{Law Commission Reports - 1980 \& 1992}

In 1980, the Criminal Law Revision Committee (the 'CLRC') - in its Fourteenth Report on Offences against the Person ${ }^{632}$ - discussed common assault (also, assault against a policeman).

- However, its consideration was very brief ${ }^{633}$ and its recommendations few viz. that assault should remain an offence and that the definition of common assault should be left to the common law; ${ }^{634}$

- As it is, this 1980 report was (effectively) superseded by a Law Commission ('LC') Consultation Paper in 1992, Legislating the Criminal Code, Offences against the Person and General Principles ${ }^{635}$ one which considered the law on common assault, as well as aggravated offences. It is now analysed:

\footnotetext{
62277 Cr App R 225.

${ }^{623}$ At $\mathrm{p} 228$.

${ }^{624}$ [1984] 1 WLR 1172.

${ }^{625}$ He cited Cole v Turner (see 14).

${ }^{626}$ At $\mathrm{p} 1177$. He cited Turberville $v$ Savage (see 14).

${ }^{627}$ [1985] 1 AE 193.

${ }^{628}$ At p 203.

${ }^{629}$ [1987] QB 237.

${ }^{630}$ At p 252-3.

${ }^{631}$ [1990] 2 AC 1, p 73 'I respectfully doubt whether whether that is correct. A prank which gets out of hand; an over-friendly slap on the back: surgical treatment by a surgeon who mistakenly thinks that the patient has consented to it - all these things may transcend the bounds of lawfulness, without being characterized as hostile. Indeed the suggested qualification is difficult to reconcile with the principle that any touching of another's body is, in the absence of lawful excuse, capable of amounting to a battery and a trespass.' See also Wainwright $v$ HO [2004] 2 AC 406, 417 per Lord Hoffman, p 417 'Battery involves a touching of the person with what is sometimes called hostile intent (as opposed to a friendly pat on the back) but which Robert Goff LJ in Collins $v$ Wilcock...re-defined as meaning any intentional physical contact which was not 'generally acceptable in the ordinary conduct of life'. See also $R v$ Brown [1994]1 AC 212, at $\mathrm{p} 244$ per Lord Jauncey who cited Wilson $v$ Pringle (see 30) as providing that 'hostility could not be equated with ill-will or malevolence'.

${ }^{632}$ Criminal Law Revision Committee. $14^{\text {th }}$ Report. Offences against the Person.(Cmnd 7844).

${ }^{633}$ It did not cite legal texts or caselaw. The report of the Working Paper on Offences against the Person (August 1976) was also very brief on assault, see p 46-9. It, basically, quoted Smith \& Hogan, Fagan (see 31) and Venna (see 31) and little else.

${ }^{634} \mathrm{Ibid}, \mathrm{p} 76$. They also thought that no new offence of threatening assault or unlawful force should be created.

${ }^{635}$ Law Commission, Legislating the Criminal Code. A Consultation Paper (HMSO, 122)('LC'). See also ATH Smith, Offences against Public Order (1987), p 183 'an assault is either the application of force to the person of another, or the threat to apply it in such a way as to cause the other to fear or apprehend that he is about to be subjected to force.' See also R Stone, Offences against the Person (1999), p 103 '[assault]
} 


\section{(a) Assault \& Battery - Confusion}

The LC cited the CLRC definition of assault:

At common law, an assault is an act by which a person intentionally or recklessly causes another to apprehend immediate and unlawful personal violence... and a battery is an act by which a person intentionally or recklessly inflicts personal violence upon another. ${ }^{636}$

The LC recognised there was confusion in that: (i) both ordinary legal usage and legislation regularly used the word 'assault' to cover both assault and battery; ${ }^{637}$ and (ii) it was unclear whether common assault was a common law, or statutory, offence. ${ }^{638}$

\section{(b) LC Recommendations}

Unlike the CLRC, the LC thought that assault and battery should be defined. ${ }^{639}$ Further (following the view of the CLRC) that it should be a single offence.

- That said, the LC were (clearly) in two minds about this ${ }^{640}$ and, in any case, they noted: 'whatever policy is eventually adopted on this point [it] will not affect the actual law to be applied., ;"64

- The LC also thought that battery (i.e. physical assault) should be called 'assault' and assault (which they called 'psychic assault') should be called 'threat to assault.' ${ }^{642}$

\section{(c) Definition - Assault}

The LC proposed (in a Clause 8(1)) that a person would be guilty of assault if:

(a) he intentionally or recklessly applies force to or causes an impact on the body of another, (i) without the consent of the other; or (ii) where the act is likely or intended to cause injury, with or without the consent of the other; or

(b) he intentionally or recklessly, without the consent of the other, causes the other to believe that any such force or impact is imminent. ${ }^{643}$

In respect of this, the $\mathrm{LC}$ also noted the following:

- Injury. For the purpose of Clause 8 (above), 'There is no need to prove injury, if such is intended, an offence is committed under clause 6 [intentional or reckless injury]'; ${ }^{644}$

- Indirect. The application need not be direct, the offence could cover cases of 'booby traps' (e.g. the D misleads the victim into falling into a pit); ${ }^{645}$

- Assault. Assault covered where there was no battery, but fear was caused of an immediate application of force (eg. a pistol was pointed at the $\mathrm{D}$ which he believed to be loaded). ${ }^{646}$ 'However, the threat must cause the person to believe that the force or impact was imminent';

refers to the situation where there is no physical contact, but where D's behaviour induces in the V a fear of unlawful violence'. Also, $p$ 111, 'battery is the application of unlawful force by the D to the V.'

${ }^{636}$ At $\mathrm{p} 37$.

${ }^{637}$ LC, $\mathrm{n}$ 635, p 37. 'This analysis [in the 1980 Report, see $\mathrm{n}$ 632] indicated the serious terminological confusion whereby the word 'assault' is sometimes limited to what may be called psychic assault, in the sense of causing an apprehension of violence; but sometimes encompasses also the actual physical contact that is technically known as battery. That confusion is increased by the use in statutes of other terms such as 'common assault.' This expression, for instance as used in the second part of section 47 of the 1861 Act, is presumably used to differentiate the assaults to which it refers from special cases of assault that attract specific and increased statutory penalties: for instance, the assault occasioning actual bodily harm that is dealt with in the first part of section 47 of the 1861 Act. However, it still has to be determined whether 'assault' when used in either of those contexts means simply (psychic) assault, or also includes battery.'

${ }^{638}$ Ibid, p 38. The LC discussed DPP v Little [1992] 1 AE 299, 304, per Mann LJ (assault was made statutory by the OPA).

${ }^{639}$ Ibid, p 39.

${ }^{640}$ Ibid. 'The creation of two clearly separate offences, whilst not making any substantive alteration in the law, might make plainer the two different types of activity that are made punishable...'

${ }^{641}$ Ibid, p 40.

${ }^{642}$ Ibid, p 39 'As to terminology...it would probably be easiest, and would certainly fit with normal if not necessarily at present strictly correct usage, to call physical assault simply 'assault', and to reserve a term such as 'threat to assault' for psychic assault...'

${ }^{643}$ Ibid, p 39.

${ }^{644}$ Ibid. The LC was recommending a separate offence of 'intentional or reckless injury.'

${ }^{645}$ It cited Martin (see n 567). Cf. M Hirst, Assault, Battery and Indirect Violence [1999] Crim LR 577. See also Kenny, n 44 (1966 ed Turner), p 218 cited as an example of a battery (also, an indirect one) the 'breaking the ice in front of a skater'. 
- Consent. [Clause 8 see above] made provision on the consent of the victim, preserving common law defences. ${ }^{647}$

- Trivial Touching. The LC sought to except these by the wording 'within the limits of what is acceptable as incidental to social intercourse or to life in the community. ${ }^{648}$ The test should be an objective one. ${ }^{649}$ The LC did not think this wording was likely to be a frequent focus of argument or decision. ${ }^{650}$

In conclusion, the LC's definition was a composite one. One which recognised that assault and battery could be committed intentionally or recklessly (but not negligently or accidentally). Also, that an act was required (omission being insufficient).

\section{Caselaw: 1990-2000}

Material cases on assault and battery in this period comprise:

- $\quad$ Spratt (1990) ${ }^{651}$ It was held that the mens rea of every type of offence against the person covered both intent and recklessness (the latter being, the taking the risk of harm ensuing with foresight that it might happen);

- Savage \& DPP v Parmenter (1992) ${ }^{652}$ The appellant had fired an air pistol from a flat, intending to hit a sign, but hit, and injured, a girl. It was held that, to establish an offence under the OPA 1861, s 20 (for actual bodily harm) the prosecution had to prove $\mathrm{D}$ intended or foresaw that his act might cause physical harm to some person - albeit it was only harm of a minor character;

- Ireland (1998) ${ }^{653}$ The appellant made a large number of phone calls to women and remained silent when they answered, causing psychological damage. Held that an assault might be committed by words or by gestures alone, depending on the circumstances. And, where the making of a silent call caused fear of immediate and unlawful violence, the caller was guilty of assault. Lord Steyn defined battery and assault. ${ }^{654}$ He thought battery could not include psychiatric injury. ${ }^{655}$ However, he considered that assault could include words alone - depending on the fact situation; ${ }^{656}$

\footnotetext{
${ }^{646}$ Ibid, p 40 'Clause 8(1)(b) [see text above] covers the case where there is no battery, but fear is caused of an immediate application of force: for instance if the $\mathrm{D}$ points a pistol at a person who believes it to be loaded. However, in accordance with the policy adopted by the CLRC, the offence does not extend to threats to strike in the future: the threat must cause the person at whom it is aimed to believe that force or impact is imminent.' (italics provided).

${ }^{647}$ Ibid. 'Clause 8 [ ] ...makes special provision in respect of the consent of the victim...existing common law defences based on the consent of the victim remain unaffected by the Bill, and the law will apply, for instance, to the offences in clauses 4-6 of the Bill [clause 4 dealt with intentional serious injury, clause 5 with reckless serious injury and clause 6 with intentional or reckless injury]. Strictly speaking, therefore, it is not necessary to mention consent in clause 8 either. However, the whole essence of an assault is that it is an act done without the consent of the victim. Since non-consensual interference is so significant an element in assault it seemed helpful to mention consent in clause 8.' Also, '[This] Clause also preserves the common law rule that, in general, one cannot consent to the infliction of injury. There are some recognized exceptions to that rule, the most obvious being the boxer or the surgeon's patient. It would have been difficult, and indeed unduly limiting, to try to provide for all such cases in the Bill. They will, therefore, continue to be exempted from liability for assault by the common law...'

${ }^{648}$ Ibid, pp 40-1. It cited Robert Goff LJ in Collins $v$ Wilcock (see 30). The LC preferred this expression to that in his judgment of 'generally acceptable in the ordinary conduct of daily life' Thus, their Clause 8.2 read '(2) Except where the force or impact is intended or is likely to cause injury, a person does not commit an offence under this section in respect of any force or impact that is within the limits of what is acceptable as incidental to social intercourse or to life in the community.'

${ }^{649}$ Ibid. 'The test is therefore an objective one.' However, 'the tribunal is likely to take into account any information that the accused had as to whether the person prima facie assaulted in fact objected to the contact involved so, to adapt one of Lord Goff's examples in his judgment...if the accused knew that a particular person objected to otherwise unobjectionable back-slapping, the tribunal might well think that such conduct towards that person was not within the limits of what society found acceptable.'

${ }^{650}$ Ibid, p 41 'Clause 8(2) is unlikely to be a frequent focus of argument or decision: people are not prosecuted in practice for trivial touchings of others. But sometimes, for instance, the question whether a police officer was acting in the execution of his duty will turn on the lawfulness or otherwise of the officer's contact with the body of a citizen whose attention he wants to attract, with whom he wishes to speak, or whom he seeks to detain or restrain. Actual detention or physical restraint requires statutory warrant or a purpose justifying the use of force, and falling within clause 28 of our Bill. But the lawfulness, in any particular circumstances, of less serious contact has to be judged against 'acceptable standards of conduct' and would therefore in future fall to be decided under clause 8(2).' The LC referred to Kenlin $v$ Gardiner (see 30), Donnelly v Jackman (see 30), Ludlow v Burgess (see 30), Bentley v Brudzinski (see 30) and Collins v Wilcock (see 30).

${ }^{651}$ (1990) 91 Cr App R 362.

652 1992] 1 AC 699.

${ }^{653}$ [1998] AC 147.

${ }^{654}$ At p 161 'battery...involves the unlawful application of force by the dependent upon the victim....assault is an act causing the victim to apprehend an imminent application of force upon her.' (Lord Steyn had mentioned that assault was often used to cover battery as well as
} 
- Haystead v Chief Constable of Derbyshire (2000) ${ }^{657} \mathrm{D}$ was found to have committed assault and battery to a child, when he punched the mother of the child in the face. She dropped the child on the ground as a result. He was convicted of battery, albeit it was indirect;

- D v DPP (2005) ${ }^{658}$ During a struggle to avoid re-capture, D brought the police officer's hand to his mouth. In such circumstances, the JP's had been entitled to find that there was a clearly foreseeable risk, taken by D, of the contact of the officer's hand with D's teeth, as D shouted and struggled.

\section{Summary of the Law on Assault \& Battery}

The law on assault and battery is rather extraordinary in that - until post 1945 - there was so much repetition by legal writers of the definition of these offences (together with 'stock' examples) and yet so little analysis of their actus reus and mens rea. The history of these offences can be stated succinctly.

\section{History:}

- Anglo-Saxon times to Bracton (c.1240). In the $6^{\text {th }}$ century the law was simple. There was a tariff system for battery (wounding) with financial penalties imposed in the case of wounds, including higher penalties when the injury affected a man's fighting ability. By the time of Bracton (c.1240) the tariff was replaced with one in which battery was a felony. Thus, the death penalty could be imposed. However, in practice, the penalty was imprisonment and a fine (the level of which was at the discretion of the court);

- Bracton (c.1240) - 1350. By Bracton (if not before), certain defences to battery were recognised, viz. (a) self-defence; (b) moderate correction of a pupil by a schoolmaster; (c) legal justification (i.e. when battery was imposed pursuant to due legal process). It was also likely that trivial batteries were not a crime. Further, Bracton and Britton advocated that victims of battery seek civil - as opposed to criminal - redress. By the $14^{\text {th }}$ century, assault (i.e. threatened battery) was recognised as a crime (as well as a tort);

- Yearbooks \& Marow (1503). The Yearbooks confirmed the principal defences to assault and battery which Marow summarised in a Reading in 1503 viz. (a) self-defence; (b) defence of certain others (wife, children, servants, villains); (c) defence of land and possessions; (d) moderate correction (of a schoolmaster, parent, gaoler, guardian, of a madman); (e) legal justification (i.e. when the assault or battery was imposed pursuant to due legal process). In all these cases the rationale was the same - there was no intent to commit a breach of the peace. These types of defence - as well as the royal courts not having cognizance of 'minor' batteries have remained unchanged to date, apart from their scope being further limited (e.g. they no longer apply vis-à-vis servants, villains, gaolers etc.). It is asserted that surgery was never recorded as a 'defence' since - from Anglo-Saxon times - it was never treated as 'inflicting' a would, being the healing of the same (i.e. therapeutic). In any case, there would be no intent to commit a breach of the peace;

- Pulton. Prior to Pulton, it seems unlikely that there was any defence based on 'consent' - even in the case of licensed tournaments (a Crown licence being required for them since 1194) since they comprised 'military' practice and, thus, exceptionally, they were governed by martial law (if a man was

assault). See also Lord Hope, p 165 who cited with approval Archbold (1997), p 1594, para 19-66 that assault comprised 'any act by which a person intentionally or recklessly causes another to apprehend immediate and unlawful violence.'

${ }^{655} \mathrm{Ibid}$, 'In my view it is not feasible to enlarge the generally accepted legal meaning of what is a battery to include the circumstances of a silent caller who causes psychiatric injury.'

${ }^{656} \mathrm{Ibid}$, 'Counsel argued that as a matter of law an assault can never be committed by words alone and therefore it cannot be committed by silence. The premise depends on the slenderest authority, namely, an observation by Holroyd $\mathrm{J}$ to a jury that 'no words or singing are equivalent to an assault'. Mead [see n 548]. The proposition that a gesture may amount to an assault, but that words can never suffice, is unrealistic and indefensible. A thing said is also a thing done. There is no reason why something said should be incapable of causing an apprehension of immediate personal violence. e.g. a man accosting a woman in a dark alley saying 'Come with me or I will stab you.' I would, therefore, reject the proposition that an assault can never be committed by words.' At $\mathrm{p} 162$ 'Whether a silent caller may be guilty of an assault, The answer to this question seems to me to be 'Yes', depending on the facts.' Weir (Introduction), n 314, p 136 said as to heavy breathing on the phone 'negligence or harassment is available here, and there is no need to extend the tort of trespass.' Also, 'Corporeal integrity is protected against direct physical invasion by the tort of battery. Physical impact is traditionally required, and this requirement should not be weakened, as was done when it was suggested that it might be a battery to take a flashlight photo of a person [Kaye v Robertson [1991] FSR 62]. It is quite unnecessary to extend the scope of trespass because if any actual harm is done, a claim in negligence will surely lie, and if the act is repealed, a claim for harassment, including an injunction.'

${ }^{657}$ [2000] 3 AE 890.

${ }^{658}$ [2005] Crim LR 962. 
killed in the tournament there was no redress). It is likely that Pulton (in 1609) and later Dalton (in 1618) and others, developed the idea that games involved 'consensual' battery, to cater for fencing and football. In hindsight, it would have been better to have based the exclusion of the criminal law in the case of such sports (whether organised or not) on the basis of the battery in such cases being either 'minor' and part of everyday human activity (Bracton and other writers from the $13^{\text {th }}$ century arguing that the royal courts did not take cognisance of minor batteries) or there being no 'intent' to commit a breach of the peace - since reference to 'consent' has developed in the late $20^{\text {th }}$ century to suggest that a person can consent to 'major' batteries, when it has never (ever) been the position under the criminal law that the court can allow parties to 'contract' out of a breach of the peace - as unlicensed tournaments, prize fighting and duels indicate (being punished not just because they might produce a breach of the peace in the participants but also because they were likely to do so in the case of bystanders);

- Marow (1503) -Turner (1945). After Marow's reading in 1503, there followed more than 400 years in which the texts of Lambard, Dalton Hawkins and Russell dominated the field and where the definitions (and examples) of Hawkins (from 1716) in respect of assault and battery pre-dominated. Unfortunately, these definitions were not of high quality since there was no proper analysis of the actus reus and mens rea. Legal texts and caselaw since Turner (1945) reflect a more detailed analysis of the actus reus and mens rea. Thus - to a great extent - they supersede prior texts and caselaw.

\section{Nature of the Offences}

- Intent \& Recklessness. It was accepted from the $6^{\text {th }}$ century that it was a crime to intentionally wound another. By Bracton (c. 1240), if not before, it was accepted that it was not a crime if accidental. Only in the $20^{\text {th }}$ century has it been fully accepted that recklessness is also a crime (but not negligence). Thus, assault and battery in the criminal sphere only cover intentional and reckless conduct. In the civil sphere it also covers negligent (and accidental) conduct;

- Ambits - Assault. As to the actus reus of assault: (a) an act is required; no crime is committed by omission; (b) an attempt to commit an assault is not a crime; (c) there is no assault if the act is unobserved by P (unlike the case of a battery); (d) there must be a present (also referred to as 'immediate' or 'imminent') act and not a future one; (e) there is no assault if D is unable to carry out his threat and P knows it; (f) no 'hostility' or 'anger' on the part of D or 'fear' on the part of P - is required for an assault; (g) an assault can be direct or indirect; (h) an assault can apply to the clothes on a person when the intent (or recklessness) is to injure the victim and not just the clothes;

- $\quad$ Ambits - Battery. There is no offence if there is no act (i.e. assault is not committed by omission). A battery must be immediate, not future. It can also be direct or indirect. A battery may be de minimis (albeit, most trivial touching will be treated as impliedly consented to or else normal communal activity could not take place). The act does not need to be done in a hostile, angry, revengeful, rude or insolent manner;

- Defences. An act in defence must be proportionate (reasonable). However, it can be pre-emptive. ${ }^{659}$ The grounds of defence (today) have, effectively, been reduced to 4: (a) self-defence, defence of others (no longer just family and servants) and of one's property (land or possessions): (b) moderate lawful correction of a child (on the basis that no breach of the peace intended or it is minor); (c) legal justification (i.e. pursuant to due legal process since there is no intent to cause a breach of the peace); (d) consent (re sports, surgery, horseplay, sexual activity). However, as noted above, the latter is better treated as being the application of 'no breach of the peace' being intended or assault or battery being minor.

\section{Archbold (2014)}

The most modern statement as to assault and battery is contained in Archbold (2015).

\section{(a) Assault}

Archbold states:

\footnotetext{
${ }^{659}$ This principle has existed since at least c.1113 (see n 102). See also Lane v Holloway [1968] 1 QB 379 (a provocative blow by P did not excuse a savage retaliation). See also Ashley $v$ Sussex Police [2008] 1 AC 192 (in a drug's raid a man was killed by a constable who asserted self-defence. The court noted that self-defence for criminal and civil purposes could be different). Per Lord Scott, $\mathrm{p} 977$ 'If a defendant's acts in the believed need for self-defence are a reasonable and proportionate response to the facts as he honestly believed them to be, it would seem to me to be quite wrong for the criminal law to impose penal sanctions on him'. Cf. where his belief was unreasonable.
} 
The term 'assault' is frequently used to include both an assault and a battery...This can lead to confusion between the two offences ${ }^{660}$... Strictly, 'assault' is an independent offence and should be treated as such. ${ }^{661}$ An assault is any act - and not mere omission to act - by which a person intentionally - or recklessly - causes another to apprehend immediate and unlawful violence. ${ }^{662}$ The act must be accompanied by a hostile intent calculated to cause apprehension in the mind of the victim. Where the hostile intent is not present, there will be no assault ${ }^{663}$ unless, of course, it is proved that the alleged assailant was reckless as to whether the complainant would apprehend immediate and unlawful violence. $^{664}$

As to examples of assault, Archbold states:

Striking at a person with a stick or fist is an assault, even though the person striking misses his aim; drawing a weapon such as a knife or throwing a bottle with intent to wound or strike, will constitute an assault; as will any other like act indicating an intention to use violence against the person of another. ${ }^{665}$ To incite a dog to bite a horse, or to strike a horse causing the rider to fall, would be assaults. ${ }^{666}$ An act may cause grievous harm or other injury, yet not constitute an assault. Causing a deleterious drug to be taken by another is not an assault. ${ }^{667}$ An unlawful imprisonment is also an assault: see Hunter $v$ Johnson $(1884)^{668}$...(detention of a child after school hours by the master, without lawful authority) and see $R v$ Linsberg and Leies $^{669}$... Words alone may constitute an assault, as may mere silence (as in a silent telephone call) ${ }^{670}$ Because of the requirement that the victim is caused to fear immediate unlawful violence, a silent telephone call is unlikely ever to constitute an assault in practice. ${ }^{671}$

\section{(b) Battery}

\section{Archbold states:}

When the term 'assault' is used to include a battery, it may be defined as an act by which a person intentionally or recklessly causes the complainant to apprehend immediate unlawful personal violence or to sustain unlawful personal violence... ${ }^{672}$ When, as is usually the case, the word 'assault' is used to mean a battery it simply means an act by which a person intentionally or recklessly applies unlawful force to the complainant. Provided those ingredients are proved, the offence will have been committed however slight the force. ${ }^{673}$

Archbold states:

- Where an assault involves a battery, it is immaterial whether the battery is inflicted directly by the body of the offender or through the medium of some weapon or instrument controlled by his actions. For an

\footnotetext{
${ }^{660}$ Archbold, n 39, cites Rolfe (see n 553).

661 Archbold cites Fagan v MPC (see 30).

${ }^{662}$ Archbold cites Venna (see 30), Smith v Chief Superintendent Woking Police Station (see 30) and Ireland (see 32). As to an omission to act founding liability, see the dubious authority of DPP $v$ Santa-Bermudez (2004) 168 JP 373 (discussed in Archbold, para 19-247)(a police officer searching through the pockets of a man, pricked her finger on a needle, having been told that nothing sharp was there. The court did not address the issue as to what constituted the assault. Nor did the court have the benefit of full argument).

663 Archbold cites Lamb (see 30).

${ }^{664}$ Archbold, n 39, para 19-221. One would assert that the wording in italics is inaccurate and that the decision is $R e F$ is correct (see $\mathrm{n} 631$ ). See also $n 602$ re Lamb. It is not the 'hostile' state of mind of the assailant that is relevant and need be proved, simply as to whether he intends to commit a battery or is reckless as to it. What is relevant is the apprehension of the victim.

${ }^{665}$ Archbold cites Hawkins and Mortin v Shoppee (see n 506).

666 Archbold cites Dodwell v Burford (see 14).

${ }^{667}$ Archbold cites Walkden (1845) 1 Cox 282 (gave a noxious thing (Spanish fly, an aphrodisiac) at a bridal party by way of a joke. Held no common assault). Per Parke B at p 283 'I am satisfied you could not have maintained the indictment, either for common assault...' It is asserted this case would be decided differently today. A battery was committed if the action of the D was intentional or reckless or negligent. Being a joke it would be not intentional (to cause injury). However, it would likely be reckless (if a reasonable person was aware that such liquid could cause injury). Thus, battery would be committed as a crime. And even if not committed a crime, battery would be committed as a tort if it was held to have been negligent to have administered the aphrodisiac.

668 (1884) 13 QBD 225.

66969 JP 107. Common Sarjeant, at p 108 'Mere false imprisonment without any belief of any lawful authority is a criminal offence...'

${ }^{670}$ Archbold cites Ireland (see 32).

671 Archbold, n 39, 19-228.

${ }^{672}$ Archbold cites Kimber (see 30).

${ }^{673}$ Archbold, n 39, para 19-222. It cites Williams (see 30), DPP v Morgan (see 30) per Lord Simon and Haystead v DPP (see 32).
} 
obiter expression of opinion that the force may be indirect, see Haystead v DPP ${ }^{674}$...The actus reus and the mens rea must be present at the same time, but it is not necessary that the mens rea should be present at the inception of the actus reus; it may be superimposed upon it. Once, however, an act has been completed without mens rea, the subsequent inception of mens rea cannot convert it into an assault ${ }^{675} \ldots$

- In relation to the offence of 'battery', the fundamental principle is that every person's body is inviolate. The effect is that everybody is protected not only against physical injury but against any form of physical molestation... ${ }^{676}$ There are exceptions, for example, the correction of children, the lawful exercise of the power of arrest, the use of reasonable force when the necessity to act in self-defence arises. Further, a broader exception exists which caters for the exigencies of everyday life such as jostling in crowded places and touching a person for the purpose of engaging his attention. The approach to the facts of any particular case where there is an element of persistence in touching should not be unreal. In each case, the test must be whether the physical contact so persisted in has in the circumstances gone beyond generally acceptable standards of conduct. Where the person causing the physical contact is a police officer who is not lawfully exercising a power (for example a power of arrest or a power to stop and search), the officer has no greater rights than ordinary citizens have; but a police officer who took the arm of a drunken and abusive woman to steady her as she came down some steep steps did not thereby assault her, as he had been acting within the bounds of what were 'generally acceptable standards of conduct' ${ }^{677}$

\section{(c) Pre-requisites \& Issues}

In considering assault and battery, Archbold states:

- Recklessness. The test was that propounded in various cases. ${ }^{678}$ Recklessness in assault, therefore, involved foresight of the possibility the complainant would apprehend immediate and unlawful violence and taking that risk. In battery, it involved foresight of the possibility the complainant would be subjected to unlawful force (however slight) and taking that risk; ${ }^{679}$

- Voluntary Intoxication. Assault and battery - being crimes of basic intent - self-induced intoxication was no defence and was irrelevant. So too, was the voluntary taking of drugs; ${ }^{680}$

- Mistake of Fact. If D may have been labouring under a mistake as to the facts, he might be judged according to his mistaken view of the facts. ${ }^{681}$ However, a D was not entitled to rely on a mistake of fact induced by his voluntary taking of alcohol or drugs; ${ }^{682}$

- Hostile Intent. Reference was made to Collins $v$ Wilcock (1984) ${ }^{683}$ and to Wilson v Pringle (1986), ${ }_{685}^{684}$ the latter being a review of principles which applied in respect of a civil claim for trespass. ${ }^{685}$

\section{Formulating a Legislative Offence}

Although the offences of assault and battery are very old and have been much discussed, as noted previously (see 33), there has been a huge amount of repetition. In alighting on an appropriate definition of assault and battery, all definitions prior to Venna (1975) (see Appendix B) are of scant worth since they fail to specify recklessness. Further, they contain various features as to the actus reus which have now been rejected. ${ }^{686}$ Thus, definitions, post-Venna, are of greater use (see Appendix C). Prior to considering assault and battery, two initial features are

674164 JP 396.

${ }^{675}$ Archbold cites Fagan v MPC (see 30).

${ }^{676}$ Archbold refers to Collins $v$ Wilcock (see 30).

${ }^{677}$ Archbold, n 39, para 19-229. Archbold cites McMillan v CPS (2008) 172 JP 485, referring to Collins v Wilcock (see 30).

${ }^{678}$ Archbold refers to Cunningham (see n 561), Spratt (see 32) and Savage, DPP v Parmenter (see 32).

${ }^{679}$ Archbold, n 39, para 19-223 refers to $D v D P P$ (see 32).

${ }^{680}$ Ibid, para 19-226 refers to DPP v Majewski [1977] AC 443 (self-induced intoxication by drink or drugs or both was not a defence).

${ }^{681}$ Archbold, n 39, para 19-225 refers to Kimber (see 30), Williams (see 30), $R$ v Beckford [1988] AC 130 and $R v$ Scarlett (1994) 98 Cr App R 290 .

${ }^{682}$ Archbold, n 39, para 19-226 refers to $R v$ O'Grady [1987] QB 995, $R v$ Hatton [2006] 1 Cr App R 16, DPP v Majewski (see n 680) and $R v$ Lipman [1970] 1 QB 152.

683 See 30.

${ }^{684}$ Archbold, n 39, para 19-227.

${ }^{685}$ Ibid, para 19-171. See also $R v B(M A)$ [2013] 1 Cr App R 36 (D forced his wife to eat a concoction, believing it to be good for her).

${ }^{686}$ e.g. that assault is an attempted battery, or that assault and battery need a hostile (or malicious) intent. 
asserted:

- Separate Offences. Assault and battery should continue to be treated as separate offences since they have been so treated for so long. ${ }^{687}$ Indeed, since the $14^{\text {th }}$ century, when assault was first recognised as a criminal offence (see 9(a)). This would also seem appropriate since assault is less serious than battery (being inchoate) such that the punishment for it should be less. Further, assault and battery have different criteria in respect of their actus reus. Thus, to combine them into one offence, would be problematic;

- Nomenclature. It is asserted that the terminology for these offences should be modernised, in order to make them more intelligible to the public. Modern nomenclature should also reflect the fact that these offences are intended to punish serious - and not de minimis - acts. Further, the nomenclature should be such that persons should seek to avoid committing these offences, so as not to be accredited with them. Thus, it is asserted that 'battery' should now be termed 'Violent Assault' and that assault should be termed 'Threatened Violent Assault.'

\section{(a) Battery}

It would seem better to approach battery first, since assault is a threatened battery. In determining on a definition, it is noteworthy that many matters of uncertainty in past centuries for legal writers now seem resolved, and that there is a high degree of unanimity among present ones. The components of battery would appear to be as follows:

- Intentionally \& Recklessly. From Venna (1975) it seems clear that this offence can be committed intentionally or recklessly; ${ }^{688}$

- Inflict Physical Injury. From Anglo-Saxon times, the actus reus of this offence has comprised the infliction of physical injury on another person. ${ }^{689}$ Further, the best definition would seem to be that of Russell (from 1819-1964) since it refers to 'corporal hurt' (i.e. physical injury). Other expressions such as 'force,," 690 'violence, ${ }^{691}$ and 'personal violence, ${ }^{692}$ are more vague and do not adequately advert to the fact that - since the $6^{\text {th }}$ century - the offence has been to cover wounds, bruises and blows inflicted on the body of another. This offence does not (and should not) include psychiatric or psychological injury; ${ }^{693}$

- Clothing. In earlier times there was a problem with people cutting the clothes of others. Thus, Russell noted that an Act of 1719, s 11 (assault with intent to spoil garments) was 'occasioned by the insolence of certain weavers and others, who, upon the introduction of some Indian fashions, prejudicial to their own manufactures, made it their practice to deface them, either by open outrage, by privily cutting, or

\footnotetext{
${ }^{687}$ Cf. the views of the Law Commission in 1980 \& 1992 (see 31).

${ }^{688}$ See definitions in Appendix C. This is appropriate since homicide and other aggravated batteries can also be committed (criminally) if there is intent or recklessness.

${ }^{689}$ Thus, Cowell referred to 'violent striking', Pulton to 'beating', Dalton to 'wounding or beating', Hawkins to 'injury', Blackstone to 'beating', Russell to 'corporal hurt' and 'injury' and Kenny to 'injury', See generally Appendices B \& $\mathbf{C}$.

${ }^{690}$ Reference to 'force' goes back to Cowell who (in 1607, see 11(b)) quoted the latin 'vim affere'. Pulton (in 1619, see 12(a)) also referred to force as did Hawkins (in 1716, see 15), Stephen (in 1883, see 25) and Lord Steyn in Ireland (in 1998, see 32). In the Victorian context, Indian legislation, see n 490, p 146 (art 349) provided: 'A person is said to use force to another if he causes motion, change of motion, or cessation of motion to that other, or if he causes to any substance such motion or change of motion or cessation of motion as brings that substance into contact with any part of that other's body, or with anything which that other is wearing or carrying, or with anything so situated that such contact affects that other's sense of feeling; provided that the person causing the motion, change of motion, or cessation of motion in one of three ways hereinafter described: First - by his own bodily power. Secondly - By disposing any substance in such a manner that the motion, or change, or cessation of motion takes place without any further act on his part or on the part of any other person. Thirdly - By inducing any animal to move, to change its motion, or to cease to move.' Also, (art 350) 'Whoever intentionally uses force to any person, without that person's consent in order to the committing of any offence, or intending by the use of such force to cause, or knowing it to be likely that by the use of such force he will cause, injury, fear, or annoyance to that person to whom the force is used, is said to use criminal force to that other.'

${ }^{691}$ Reference to 'violence' goes back to Lambard (see 10(b)) who referred to 'violence... done unto his own person'. Pulton (in 1619, see 12(a)) also referred to 'force and violence', as did Hawkins (in 1716, see 15).

${ }^{692}$ Reference to 'personal violence' goes back to Lambard (in 1581, see n 10). Smith \& Hogan (in 1965, see 28(d)) referred to 'personal violence' as did James J in Fagan (in 1969, see 30). So did the Law Commission in 1980 \& 1992 (see 31).

${ }^{693}$ See Lord Steyn in Ireland (see 32). To extend battery to include psychiatric (or psychological) injury would be to fundamentally change the substantive nature of the offence of battery where, from the $6^{\text {th }}$ century onwards, it was intended to cover blows and wounds sustained mainly from fighting and quarrels, on the basis that the same led to a breach of the peace. See also OED, n 245 (quarrel) 'A violent contention or altercation between persons, or of one person with another; a rupture of friendly relations.'
} 
by casting aqua fortis [i.e. nitric acid] in the streets upon such as wore them.' ${ }^{69}$ In a case on this (Porter, 1790), it was held that this legislation only applied where the primary intention was to tear, cut etc. clothes and not when it was to injure a person, in the course of which their clothes were torn, cut etc. ${ }^{65}$ This legislation was repealed in 1826. In Day (1845), a knife was used to scar the frock of a woman. Parke B held that it was an assault to the person 'though the blow is received by the coat on the person.' 696 One would agree - although, if the intent was simply to damage the clothes - it should be a matter of criminal damage. If the intent was to injure the person, then it should be a battery;

- Act not Omission. Since the act comprises the 'infliction' of physical injury, it is not committed by omission; ${ }^{69}$

- $\quad$ Direct \& Indirect. A number of cases make it clear that a battery may be direct or indirect. ${ }^{698}$ Thus, a person can hit a person with his hand or a weapon, or he can use the hand of another. Further, he can hit a horse on which a person is riding, or pull away a ladder on which a person is standing. ${ }^{69}$ There would also seem no reason why a person who intentionally (or recklessly) digs a pit for another to fall into (or who breaks the ice in front of a skater) should not fall within the embrace of 'indirect'; 700

- Immediate not Future. The offence requires the immediate (also termed 'imminent' or 'present') infliction of physical injury - not that in the future, ${ }^{701}$

- Injury Unlawful. The infliction of the physical injury must not fall within various long-standing defences. These are discussed later (see 38).

Certain things are not required for this offence. Thus:

- Damage. Proof of damage (injury) is not required; ${ }^{702}$

- $\quad$ Trivial Injuries. The physical injury for a battery may be de minimis- albeit that most trivial touching will be treated as consensual; 703

- $\quad \underline{\text { Hostility. }}$. The act does not need to be done in a hostile, angry, revengeful, rude or insolent manner; ${ }^{704}$

- $\quad$ Attempted Battery. There is no crime of 'an attempt to commit a battery' or 'attempted battery'. Instead, assault is the inchoate offence. ${ }^{705}$

\footnotetext{
${ }^{694}$ Russell, n 38, vol 1, p 888. Russell refers to Blackstone, n 36, vol 4, p 244 'By statute 6 Geo I c 23 [1719] the willful and malicious tearing, cutting, spoiling, burning, or defacing of the garments or cloaths of any person passing in the streets or highways, is a felony. This was occasioned by the insolence of certain weavers and others; who, upon the introduction of some Indian fashions prejudicial to their own manufactures, made it their practice to cast aqua fortis in the streets upon such who wore them.' The Act made this crime a felony, with the courts having power to order transportation for 7 years (the prisoner had committed a similar offence on seven other ladies and was sentenced to 6 years, in respect of three of them, see Russell, p 891).

${ }^{695}$ See Porter (1790), referred to in Russell, n 38, vol 1, pp 889-90. See also Chitty, n 261, p 92a.

${ }^{696}$ See $\mathrm{n}$ 492. See also Smith \& Hogan, n 566. See also Thomas (1985) 81 Cr App R 33 (touching skirts).

${ }^{697}$ See James J in Fagan (see 30) 'a mere omission to act cannot amount to an assault.' See also Innes $v$ Wylie, n 480, Smith \& Hogan, n 556, Kenny ( see 27(b)) and Archbold ( see 34(a)). See also Weir, (Casebook), n 314, p 321 (in relation to the civil position) 'no liability in trespass for omissions, however clear the duty to act.'

${ }^{698}$ e.g. Fagan (see 30). See also: (a) DPP $v K$ [1990](schoolboy liable for injury to another pupil as a result of pouring acid onto the nozzle of a hair dryer which then blew it into the face of the other, disfiguring him); (b) Ball v Axten (1866) 4 F \& F 1019 (176 ER 890)(altercation between a farmer and the $\mathrm{D}$ who was hunting without permission on his land. D struck a blow at the farmer's dog but hit his wife. per Cockburn CJ at p 1020 'even though the defendant had not aimed the blow at the woman, there was no doubt an assault.' See also Trindade, n 319, 224; (c) Livingstone v MOD [1984] NI 356 (soldier fired a baton round targeting X but hit P). See also Smith \& Hogan, n 567.

${ }^{699}$ See also older cases involving the hitting of horses as a result of which the rider fell and was injured (see 14(b)). See Collins $v$ Renison (1754) Say 138 (96 ER 830)(overturning a ladder on which a person was standing).

${ }^{700}$ See Law Commission (booby trap, n 645) and Kenny (skier), n 645. Cf. Weir (Casebook), n 314, (re civil position in trespass), p 321 '[if] the invasion [of a protected right of a person] was indirect, however foreseeable, there was no liability in trespass.'

${ }^{701}$ See East (see 20) who referred to'present ability'. The position re assault is the same. See also $R v$ Horseferry Road Metropolitan Stipendiary Magistrate, ex p Siadatan [1991] 1 QB 260, p 269 per Watkins LJ 'It seems to us that the word 'immediate' does not mean 'instantaneous'; that a relatively short time interval may elapse between the act which is threatening, abusive or insulting and the unlawful violence. 'Immediate' connotes proximity in time and proximity in causation; that it is likely that violence will result in a relatively short period of time and without any other intervening occurrence.'

${ }^{702}$ See Law Commission, $\mathrm{n}$ 644. The position in tort is the same. See Weir, (Casebook), n 314, p 322 (re the civil position) 'the law of trespass does not insist on damage.' See also Ashley v Sussex Police (see n 659) and Loudon v Ryder [1953] 2 QB 202.

${ }^{703}$ See Cole v Turner (14), per Holt CJ 'least touching'. These words were also used by Blackstone (see 17(b)) and Disney (see n 504).

${ }^{704}$ As a 'hostile' act, as previously noted, Holt CJ from whom this proposition derives (see Cole v Turner, 1704, see 14) was more likely seeking to distinguish batteries which were consensual from those which were not.
} 
On all the above points, modern writers on the criminal law - as well as judgments - now seem clear.

\section{(b) $\underline{\text { Assault }}$}

Various propositions seem clear:

- Intentional or Reckless. Like battery, an assault may be intentional or reckless - but not negligent or accidental in the criminal sphere; ${ }^{706}$

- $\quad$ Threat to Commit a Battery. An assault is a threat to commit a battery. Lambard (1581) and Cowell (1607) referred to the 'offering' of a blow (i.e. an attempt) and Pulton to an 'attempt', rather than to a threat, since there was a separate common law offence of threatening (menaces). This was later picked up by Hawkins (in 1716 'attempt or offer'), Russell (in 1819 'attempt to offer') and Kenny (in 1904, 'an attempt or offer'). However, it is very likely that - had there not been a separate offence of menacing in those times - the word 'threat' would have been used, since it would have covered threats in the form of words being an assault (see case in 1353, see 9(a)) as well as by gesture (waiving a fist, sword etc.). Today, there is no good reason why the word 'threat' cannot be used and it has been used by legal writers such as Lambard, Pulton, Kenny (later editions) and Turner (see Appendix C);

- $\quad$ Threat - Words. Under Roman law, an assault (assultus) could include an insult (insultus)(i.e. attacking a person in terms of their reputation) and writers such as Bracton, Lambard, Cowell and Dalton treated verbal threats as an assault. However, Hawkins (see 15), contrary to this and other old authorities and without citing (it seems) good authority, rejected this and subsequent writers followed him, until Glanville Williams questioned matters in an article in 1957 (see 28). Today, one would argue that verbal threats are better governed by the law on harassment ${ }^{707}$ rather than by reference to assault unless the verbal threat is also accompanied by a gesture (e.g. 'get the knives out, boys', and they get the knives out). ${ }^{708}$ Otherwise, there will simply be confusion between the two offences;

- $\quad$ Assault is a Separate Offence. There can be an assault without a battery; ${ }^{709}$

- Act-Not Omission. Like battery, there can be no assault by way of omission. There must be an act such as a gesture (waiving a sword) or acts; ${ }^{710}$

- Direct \& Indirect. Like battery, an assault can be direct or indirect ${ }^{711}$

- Immediate not Future. The offence requires a threat which is immediate, not in the future. ${ }^{712}$ Nor one which is conditional (which is the same as saying, in this instance, that it not be in the future) $;{ }^{713}$

- Apprehension. Smith and Hogan referred to assault as an act which causes $\mathrm{P}$ to apprehend 'immediate and unlawful personal violence' (see 28). ${ }^{714}$ The words in italics simply refer to a battery. The key word is 'apprehension'. This need not be 'fear' ${ }^{\text {' }} 15$ - simply 'apprehension' of a battery. Such 'apprehension' must be reasonable. Further, by its nature, such apprehension means that: (a) no assault

\footnotetext{
${ }^{705}$ Cf. Smith \& Hogan, n 564 (attempt to commit an assault).

${ }^{706}$ See Appendix C including definitions of James LJ in Venna, Lord Simon in Williams, Lawton LJ in Kimber, the Law Commission and Archbold.

${ }^{707}$ See Weir, n 656. Also, Protection from Harassment Act 1997, s 1. See also Khorasandjian v Bush [1993] 3 WLR 476 (harassment by unwanted phone calls amounting to interference with the ordinary and reasonable enjoyment of property which the recipient of the calls had a right to occupy was actionable as a private nuisance notwithstanding that she had no proprietary interest in the house (she was the daughter of the owners of the house)).

${ }^{708}$ See $R v$ Wilson [1955] 1 WLR 493, 494 per Goddard CJ 'get out knives'. Cobbett v Grey (1849) 4 Exch 744 (154 ER 1409) per Pollock CB, at $\mathrm{p} 744$ 'I have considerable doubt whether any mere threat, not in the slightest degree executed, that is, a person saying to another 'If you do not move, I shall use such and such force' is an assault...'

709 e.g. Stephens v Myers (see n 509). See also Smith \& Hogan, n 555 'Assault is an independent crime and should be treated as such.'

710 e.g. Smith \& Hogan, n 556.

${ }^{711}$ A threat would be indirect by a person saying to another 'Hit him', meaning a third person in their presence.

${ }^{712}$ Cobbett v Grey (1849) 4 Exch 744 (154 ER 1409) per Pollock CB, at $\mathrm{p} 744$ 'I do not know at what distance it is necessary for the party to be. No doubt, if you direct a weapon, or if you raise your fist within those limits which give you the means of striking, that may be an assault: but if you simply say at such a distance as that at which you cannot commit an assault, 'I will commit an assault', I think that is not an assault.' See also Williams, n 545, Smith \& Hogan, n 559, Read v Coker (see n 547), the Law Commission (see 31) and Stephens v Myers (see n 509).

${ }^{713}$ See Turberville $v$ Savage (see 14).

${ }^{714}$ See also Law Commission (see 31).

${ }^{715}$ See $R v$ Norden (1755) Fost 129 (168 ER 64)(apprehended a highwayman. No fear or fright). Also, R v Lamb (1967) 51 Cr App R 417 (both $\mathrm{P}$ and $\mathrm{D}$ thought gun would not fire. Thus, no fear).
} 
is committed if the act is unobserved by $\mathrm{P} ;{ }^{716}$ and (b) no assault is committed if D is unable to carry out the threat and D knows it. For example, if D presents a gun, and $\mathrm{P}$ knows it is unloaded. Or D threatens $\mathrm{P}$ from such a distance that he cannot reach him. ${ }^{717}$ It is also asserted that the word 'apprehension' in this context is the same as 'belief' and that the latter word is more clearly understood in normal and modern parlance and, thus, should be used.

Certain things are not required for this offence:

- Like battery, assault does not need to be done in a hostile or done in an angry, revengeful, rude or insolent manner;

- An attempt to commit an assault is not a crime; being too remote.

Thus, assault (essentially) comprises (it is asserted) a 'threat to commit a battery'.

In conclusion, the law on assault and battery has been be-devilled by terminology, viz. attempts to translate the latin concept (in legal terms) of 'assultus', with its many synonyms. This has produced the English word to 'batter', with its many synonyms. Also:

- today, the mens rea of battery and assault seems uniformly agreed - intent or recklessness;

- the actus reus of battery also seems agreed - with the possible exception of whether physical 'force' is a more appropriate word than 'physical injury' (which includes the least touching). One would assert that the latter is more definitive and accurate;

- as to assault, it should comprise the reasonable apprehension (belief) of a threatened battery - one where words alone are insufficient unless unaccompanied by some gesture or other act.

\section{Wording of a Legislative Offence}

It is asserted there should be offences of Violent Assault (formerly battery) and Threatened Violent Assault (formerly assault). The former is the more important to define since the latter is simply a threat to perform the former which is not then carried out.

\section{(a) Violent Assault}

Possible wording for such an offence might be:

1. It is a crime to:

(a) intentionally or recklessly

(b)inflict (whether directly or indirectly) $)^{718}$

(c) unlawful ${ }^{719}$

(d)physical injury ${ }^{720}$

on a person.

'Person' includes any clothes they are wearing, if the intent (or recklessness) was to inflict injury on the person and not only their clothes. ${ }^{721}$

\section{(b) Threatened Violent Assault}

Possible wording for such an offence might be:

\footnotetext{
${ }^{716}$ See Turner, n 535 (a person might be asleep etc.). Also, Smith \& Hogan, see n 557. Cf. a battery can be unobserved such as hitting a person from behind.

${ }^{717}$ See Kenny (see 27(a)) and Smith \& Hogan, n 558. Also, Stephens v Myers (see 509).

718 'Inflict' is the English translation of Ulpian (percutere), see $\mathrm{n}$ 262. Also referred to by Cowell, see 11(b). Further, it (appropriately) is used in the OPA 1861, s 20, which is simply an aggravated battery. Further 'cause' in the OPA 1861, s 18 is the same as inflict.

${ }^{719}$ For defences, see 38 \& 39.

${ }^{720}$ The Law Commission proposed the word 'injury' in 1992 (see n 635, p 29. See also p 31) and this word would seem apposite (as well as accurately reflect the position since Anglo-Saxon times, see Appendix F). The alternative would be to refer to 'physical force.' This is similar to the definition of Goff LJ in Collins v Wilcock (see 30) viz.'actual infliction of unlawful force on another', with 'force' being replaced by 'personal injury' (in order to exclude psychiatric and psychological injury) and to evidence that there must be some injury (however slight). However, force would not seem appropriate in all circumstances. For example, air is force. However, to stand aside from a person intentionally (or recklessly) so that the wind blows on them, would not be a battery.

${ }^{721}$ See 35(a). See also Donovan (n 541) at p 509, per Swift J 'bodily harm' has its ordinary meaning and includes any hurt or injury calculated to interfere with the health or comfort of the prosecutor. Such hurt or injury need not be permanent, but must, no doubt, be more than merely transient and trifling.' Cited by Lord Templeman, in Brown (see n 631), p 230.
} 
2. It is a crime to:
(a) threaten a person
(b)so that he reasonably believes
(c) an immediate
(d)violent assault

will be inflicted on him. ${ }^{722}$ No crime is committed if the threat:

(e) is by words alone, without any accompanying act or gesture; or

(f) it is unobserved by the person; or

(g) it cannot be carried out and the person knows it.

\section{Assault \& Battery as a Tort}

- In Anglo-Saxon law, no distinction was made in respect of criminal and civil law, vis-à-vis wounding. However, by the time of Bracton (c. 1240), he (as well as Britton, c. 1290) was recommending that victims of minor wounds seek civil, rather than criminal, redress. This likely helped the development of the civil law of trespass - one which included assault, when the latter was recognised as a crime in the $14^{\text {th }}$ century (see 9);

- Thereafter, there has been the long (and tortuous) story of the criminal law recognising assault and battery when: (a) intentional; or (b) reckless, but not when (c) negligent or (d) accidental;

- In earlier times, the legal nature of assault and battery as a crime or a tort was not different and it is asserted that it should remain so today - save that assault and battery should only be a crime when it is intentional or reckless (but a tort when intentional, reckless or negligent).

As to whether the crime and tort, presently, co-incide, reference made by made to a plethora of modern texts on tort, which discuss assault and battery. ${ }^{723}$ However, since most of them say the same thing, it would seem appropriate to refer to two principal texts, Deakin (2013) and Clerk \& Lindsell (2014).

\section{(a) Battery}

Deakin states:

The tort of battery consists of a direct act of the defendant resulting in an undesired contact with the person of the claimant. ${ }^{724}$

Deakin also notes that:

- the battery can be nominal (ie. de minimis) (the same as the criminal law); ${ }^{725}$

- $\quad$ it does not need to be hostile (the same as the criminal law); ${ }^{726}$

\footnotetext{
${ }^{722}$ See Appendix C where 'apprehends' is used. However, 'apprehends' is a synonym for 'believes' or 'understands' in this instance (see LC 1992, in Appendix C). It is not a reference to 'apprehend' in the sense of becoming conscious of something. It is a reference to 'apprehend' in the sense of 'understand'. See OED, n 245 (definition to apprehend) includes: 'To become or conscious by the senses of (any external impression). Also, 'to understand (although to be so and so) to conceive, consider, view, take (it) as.' See also Trindade, n 319, p 233-4 (reasonable apprehension). As to 'immediate', Ireland (1998, see Appendix C) refers to 'imminent'. However, 'immediate' would seem a better formulation. See also Trindade, n 319, p 233 (imminent bodily contact).

${ }^{723}$ These include: (a) E Peel et al, Winfield \& Jolowicz on Tort (19 $9^{\text {th }}$ ed, 2014); (b) S Deakin et al, Markesinis and Deakin's Tort Law (7th ed, 2013); (c) N McBride et al, Tort Law (4 $4^{\text {th }}$ ed, 2012), (d) LN Klar, Tort Law (5 $5^{\text {th }}$ ed, 2012); (e) S Hadley, Tort ( $7^{\text {th }}$ ed, 20111); (f) V Hargwood, Modern Tort Law ( $7^{\text {th }}$ ed, 2009); (g) Hepple \& Matthews, Tort. Cases and Materials $\left(6^{\text {th }}\right.$ ed, 2009), (h) K Horsey, E Rackley, Tort Law ( ${ }^{\text {rd }}$ ed, 2013), (i) J Steele, Tort Law. Text, Cases and Materials ( $3^{\text {rd }}$ ed, 2014), (j) SI Strong \& L Williams.Tort Law. Text, Cases and Materials ( $2^{\text {nd }}$ ed, 2011); (k) Clerk \& Lindsell on Torts (21 ${ }^{\text {st }}$ ed, 2014); (1) P Giliker, Tort (15 $\left.5^{\text {th }}, 2014\right)$; (m) C Elliott \& F Quinn, Tort Law (8th ed, 2011); (n) J Cooke, Law of Tort (1 $11^{\text {th }}$ ed, 2013), (o) Weir (Introduction), see n 314; (p) C Turner \& S Hodge, Unlocking Torts ( ${ }^{\text {rd }}$ ed, 2010); (q) Weir, (Casebook), n 314; (r) NJ McBride \& R Bagshaw, Tort Law (4 ${ }^{\text {th }}$ ed, 2013); (s) J Murphy \& C Witting, Street on Torts (13 ${ }^{\text {th }}$ ed, 2012), (t) Salmon $\&$ Heuston, Law of Torts (21 $1^{\text {st }}$ ed, 1996); (u) Hepple \& Matthews, Tort (6 ${ }^{\text {th }}$ ed, 2009);(v) M Lunney \& K Oliphant, Tort Law (5 ${ }^{\text {th }}$ ed, 2013). See also Trindade (in 1992), n 319.

${ }^{724}$ Deakin, n 723, p 363. He also states: 'But the defendant need not necessarily have intended to make contact with the claimant as opposed to another in the vicinity of the claimant.' Deakin cites Bici v MOD [2004] EWHC 786 (MOD liable for negligence and trespass to the person arising from British soldiers having fired shots killing and injuring Kosovar Albanians during a peacekeeping operation).

${ }^{725}$ Deakin refers to Ashton $v$ Jennings (1675) 2 Lev 133 (83 ER 485) (woman placed a hand on another to assert higher social status).

${ }^{726}$ Deakin refers to Wilson $v$ Pringle (see 30) but asserts that the decision is wrong on this, stating that it 'seems contrary to authority and is probably incorrect. The need to find some element of hostility was thought to arise in order to avoid the conclusion that incidental contact in the street or in a crowd can constitute battery.' Deakin also refers to the cases in n 631. See also Murphy \& Witting, n 723 , p 260 'Yet the term
} 
- contact must be direct. However, it is asserted this proposition (which came from the different actions in trespass and trespass on the case) is no longer correct vis- $a$-vis tort ${ }^{727}$ and it is incorrect in respect of the criminal law on battery; ${ }^{728}$

- a person may seek civil - as well as - criminal redress. ${ }^{729}$

For its part, Clerk \& Lindsell on Torts (2013) note:

The direct imposition of any unwanted physical contact on another person may constitute the tort of battery. ${ }^{730}$

However, (as with Deakin) it is asserted that the limitation to 'direct' is no longer correct, since the contact may be indirect ${ }^{731}$ and there is no good reason why the tort should be different to the criminal, position. Clerk \& Lindsell also note that there is no requirement to prove injury (same as the criminal law). ${ }^{732}$ In conclusion:

- the above principles referred to by Deakin and Clerk \& Lindsell in respect of assault and battery as a tort, also apply vis-à-vis the same as a crime;

- as for the many other modern legal texts or tort, they invariably cite the same propositions as Deakin and Clerk \& Lindsell do. Nor do they seem to draw any other disparity between the crime and the tort save that the former is restricted to intentional, or reckless, conduct. ${ }^{733}$

\section{(b) Assault}

Deakin states:

The conduct forbidden by this tort is an act which threatens violence, or in other words, one that intentionally induces in the claimant a reasonable expectation of immediate unlawful force. ${ }^{734}$

Deakin also notes that assault is both a tort and a crime and that the 'relevant principles of law apply to both' as well as that the two torts are distinct; there can be one without the other. Deakin also notes the following:

- The threat must relate to immediate - not future - force (the same as the criminal law); ${ }^{735}$

\footnotetext{
'hostility' is not to be equated with ill will or malevolence. It means merely that the defendant is doing something to which the claimant may object, something that the claimant may regard as an unlawful intrusion on his rights to physical integrity.'

${ }^{727}$ Deakin, n 723, p 363 doubts whether this requirement still prevails, noting: 'It seems that there could be liability where the interference is brought about intentionally but indirectly.' It is asserted that, since there are no longer separate actions in trespass and case, there is no reason why there should now be a distinction between the criminal, and tort, positions $r e$ direct and indirect actions - not least because the distinction was, in the end, so narrow.' See also Leame v Bray (1803) 3 East 593 (102 ER 724)(A accidentally drove his carriage against B. The remedy was trespass and not case, the injury being immediate [direct] from the act done and not consequential). Lunney \& Oliphant, n 723, p 61 'Not only must the defendant act positively, the contact or apprehension of contact must be the direct result of the act. This is a hangover from the old forms of action where trespass vi et armis could only be brought for direct interferences. Contact may still be direct even if achieved through the use of an intervening object; hence hitting or touching another with a stick will be sufficient.' Horsey, n 723, p 382 'While the former [i.e. a direct act] lies in battery, the latter is said to be restricted to the tort of negligence (Reynolds v Clarke, 1725 [see 2 Ld Raym 1402 (92 ER 410)]). In practice, however, it seems the courts have interpreted the 'directness' requirement extremely flexibly.' See also Wong $v$ Parkside [2003] 3AE 932, at p 933 per Hale LJ. Also, Trindade, n 319, p 225.

${ }^{728}$ Deakin cites Dodwell v Burford (see 14) which is (actually) an indirect battery. See also Hopper v Reeve (see n 529); Hedley, n 723 , p 46 and Sterman v EW \& WJ Moore Ltd [1970] 1 QB 596.

${ }^{729}$ Deakin, n 723, p 363 'Since assault and battery are crimes as well as torts, statute has made provision for avoiding unnecessary double process. Criminal proceedings will be a bar to further civil proceedings where the hearing was a summary one and ended, after a hearing on the merits, either with a certificate of dismissal or with the accused being convicted and either being imprisoned or paying the fine levied on him.' [Deakin cites OPA 1861, ss 42-5 as well as Ellis v Burton [1975] 1 WLR 386.] However these provisions do not prevent civil actions being brought in respect of more serious crimes tried on indictment; nor do they prevent actions being brought against those who, for one reason or another, are not prosecuted.' Deakin cited Halford v Brookes [1991] 1 WLR 428].

${ }^{730}$ Clerk \& Lindsell, n 723, para 15-09.

${ }^{731}$ They refer inter alia, to Hopper $v$ Reeve (see n 529), Collins $v$ Renison (see n 699) and Haystead (see 32) as examples of battery. However, these are indirect.

${ }^{732}$ Clerk \& Lindsell, n 723, para 15-09 'There is no requirement to prove that the contact caused or threatened any physical injury or harm.' The same applies with regard to the criminal offence, see $\mathrm{n} 702$.

${ }^{733}$ Some of these texts also discuss the direct/indirect issue, see $\mathrm{n} 723$ for texts.

${ }^{734}$ Deakin, n 723, p 361 cites $R v$ Beasley (1991) 73 Cr App R 44 (concerning the OPA 1861, s 20 (see 43)(such an offence could be committed without intending to frighten and without the victim being frightened or aware of what was going on. This is not the case in respect of common assault). As to the need for an assault to involve the victim being 'frightened', this is incorrect; as to the need for awareness (apprehension), this is correct.

${ }^{735}$ Deakin refers to Mbasago v Logo Ltd (No 1) [2007] QB 846 (President of Equatorial Guinea attempted to sue a group of people whom he
} alleged had attempted to overthrow him by paying for mercenaries to kill him. Claim for assault dismissed by the Court of Appeal on the basis 
- The reaction induced in the defendant need not have any fright or fear - merely, the apprehension of force (the same as the criminal law), ${ }^{736}$

- So long as P reasonably expects immediate force, D's ability to actually apply it is not essential (the same as the criminal law); ${ }^{737}$

- The necessary mens rea is intention or recklessness (the same as the criminal law); ${ }^{738}$

- Words per se do not comprise an assault (the same as the criminal law). ${ }^{739}$

For their part, Clerk \& Lindsell, for a definition of assault, quote Collins $v$ Wilcock (1986). ${ }^{740}$ They also note that:

- The substance of an assault is an act causing reasonable apprehension of a battery (the same as the criminal law) ${ }^{741}$

- Where the assailant is in close proximity to the victim - but cannot carry out its threat - there is no assault. ${ }^{742}$ One would dis-agree. It is not the ability of the assailant, but the (reasonable) belief of the potential victim which matters;

- Threats, per se, do not constitute assault (the same as the criminal law); ${ }^{743}$

- Omission is not an assault, but active blocking is (the same as the criminal law). ${ }^{744}$

These tort principles also apply vis-à-vis the crime of battery. The many other tort texts on assault and battery besides Deakin and Clerk \& Lindsell, invariably cite the same propositions as above. Further, they do not seem to draw any disparity between the crime and the tort - save that the former is restricted to intentional or reckless conduct (but excludes negligent or accidental conduct). ${ }^{745}$

In conclusion, it is asserted that the tort and crimes of assault and battery should be the same - save that the former should be limited to intent and recklessness. Modern tort texts appear to accept this, questioning whether any limitation in the tort to direct (but not indirect) acts should continue - even if this still prevails (various tort writers were dubious that it did).

\section{Defences to Assault \& Battery}

The categories of defences to assault and battery have not changed for 500 years. However, these defences are now more circumscribed and they have been clarified - as well as superseded (to an extent) by legislation. As to these:

\section{(a) Defences - Self Defence}

Self-defence was accepted as a defence in the case of homicide in the Laws of Henry I (c.1113) ${ }^{746}$ and, doubtless, long before. Bracton accepted it as a defence to homicide and hamsocn ${ }^{747}$ and there would seem little doubt that

that the claimant was not, in fact, in danger of an immediate attack). Deakin also refers to Mortin v Shoppee (see n 506) stating, p 361, 'pointing an unloaded gun at the claimant is common law assault if he does not know it is unloaded; and it is still assault even though the plaintiff manages to escape'. Also 'or if the defendant is restrained before actually hitting him' (Deakin refers to Stephen v Myers, see n 509).

${ }^{736}$ Deakin cites Norden (see n 715).

${ }^{737}$ Deakin, n 723, p 361.

${ }^{738}$ Deakin refers to Venna (see 30) and Bici v MOD (see n 724).

739 Deakin refers to Mead (see n 548).

${ }^{740}$ Clerk \& Lindsell, n 723, para 15-12 'An assault is an act which causes another person to apprehend the infliction of immediate, unlawful, force on his person.'

741 Ibid, para 15-13.

${ }^{742}$ Clerk \& Lindsell cite Thomas $v$ NUM [1986] Ch 20 (Mineworkers bussed into work passed through a considerable number of pickets who were making violent threats and gestures. Held this could not be an assault since there was no way in which the pickets could reach those in the bus). Hedley, n 723, p 45 'There is no liability for assault if the defendant makes a threat which the claimant knows the defendant cannot carry out or where the defendant points a gun at a claimant which the claimant knows is not loaded.'

${ }^{743}$ Clerk \& Lindsell, n 723, para 15-12 'Accordingly, the claim for harassment created by the Protection from Harassment Act 1997 may, in many cases, offer the claimant a more favourable remedy than the tort of assault.'

${ }^{744}$ Ibid, para 15-13. They cite Murray v MOD [185] 12 NIJB 12 and Hepburn v Chief Constable of Thames Valley Police [2002] AE (D) 214 (police officer's use of force and consequent assault on the claimant was not reasonable since it had been based on an unlawful act).

745 See Appendix C.

746 See 5(a). With respect to defences see also Law Commission, Consent and Offences against the Person (no 134, 1994). However, much of this paper is now dated.

${ }^{747}$ See 7(b). 
Bracton would have also applied it to battery (as a consequence of its application to homicide). Archbold states, in respect of homicide:

The classic pronouncement upon the law relating to self-defence is that of the Privy Council in Palmer $v R,^{748}$ approved and followed by the Court of Appeal in $R v$ McInnes $^{749} \ldots$ and now effectively reflected in the provisions of the CJIA 2008 , s $76 .^{750}$

Archbold (2014) notes that:

- 'The old rule of law that a man must retreat as far as he can has disappeared'; 751

- 'There is no rule of law that a man must wait until he is struck before striking in self-defence. ${ }^{752}$ The latter principle (that a person may act pre-emptively) is as old as the Laws of Henry I. (53 $^{2}$

As to self-defence, the Criminal Justice and Immigration Act 2008, s 76 ('CJIA 2008')(reasonable for the purposes of self-defence $e t c$.) provides:

(1) This section applies where in proceedings for an offence - (a) an issue arises as to whether a person charged with the offence ("D") is entitled to rely on a defence within subsection (2), and (b) the question arises whether the degree of force used by D against a person ("V") was reasonable in the circumstances.

And, as to this:

- Common Law - Self Defence. The defences referred to in (2) are the common law defence of self-defence - as well as defences relating to the use of force in the prevention of crime and in respect of the making of arrests, as referred to in the Criminal Law Act 1967 ('CLA 1967'), s 3; 754

- Reasonable Force. Section 76 also provides that the question whether the degree of force used by defendants was reasonable in the circumstances is to be decided by reference to the circumstances as D believed them to be (reference is made to various sub-sections in connection with deciding that question). ${ }^{755}$

\footnotetext{
748 [1971] AC 814, pp 831-2, per Lord Morris 'It is both good law and good sense that a man who is attacked may defend himself. It is both good law and common sense that he may do, but only do, what is reasonably necessary. But everything will depend upon the particular facts and circumstances...It may in some cases be only sensible and clearly possible to take some simple avoiding action. Some attacks may be serious and dangerous. Others may not be. If there is some relatively minor attack, it would not be common sense to permit some act of retaliation which was wholly out of proportion to the necessities of the situation. If an attack is serious so that it puts someone in immediate peril, then immediate defensive action may be necessary. If the moment is one of crisis for someone in imminent danger, he may have to avert the danger by some instant reaction. If the attack is all over and no sort of peril remains then the employment of force may be by way of revenge or punishment or by way of paying off an old score or may be pure aggression. There may no longer be any link with the necessity of defence. Of all these matters the good sense of the jury will be the arbiter.'

749 (1971) 55 Cr App R 551.See also P Carter \& R Harrison, Offences of Violence (Waterlow, 1991), pp 46-9.

${ }^{750}$ Archbold, $\mathrm{n}$ 39, para 19-46. See also $R v$ Clegg [1995] 1 AC 482 (where a person used a greater degree of force in self-defence than was necessary in the circumstances and the death of a person resulted, it was murder. That there was no distinction to be drawn between the use of excessive force in self-defence and the use of excessive force in the prevention of crime or in arresting an offender. And, that it made no difference that the person using it was a soldier or a police officer acting in the course of his duty). For the position in tort, which should not be any different, see Clerk \& Lindsell, n 723, para 15-52 et seq. It is asserted a person assisting a police officer should not have any enhanced protection since that under the general law is wholly adequate. See also Clerk \& Lindsell, para 15-91.

${ }^{751}$ Ibid 'Whether the accused did retreat is only one element for the jury to consider on the question of whether the force was reasonably necessary. Failure to demonstrate unwillingness to fight is merely a factor to be taken into consideration in determining whether a defendant was acting in self-defence, although evidence that he tried to call off a fight is likely to be the best evidence to cast doubt on a suggestion that he was the attacker, retaliator or acting in revenge and thus was not acting in self-defence. $R v$ Bird (D) [1985] 81 Cr App 110.'

752 'If another strikes at him he is entitled to get his blow in first if it is reasonably necessary so to do in self-defence $R v$ Deana [1909] 2 Cr App $\mathrm{R} 75$, CCA. And the mere fact that the defendant was the initial aggressor does not of itself render self-defence unavailable as a defence to what he does in any ensuing violence; availability must depend on all the circumstances, and allow for the possibility that the initial aggression may have resulted in a response by the victim which was so out of proportion as to give rise to an honest belief on the part of the defendant that it was necessary for him to defend himself, with the amount of force used for that purpose being reasonable.' Archbold cites $R v$ Rashford [2006] Crim LR 547 and $R v$ Keane, $R v$ McGrath [2011] Crim LR 393.

${ }^{753}$ See $\mathbf{5}(\mathbf{a})$.

${ }^{754}$ Section 76(2) refers to the Criminal Law Act 1967 s 3 (and its Northern Ireland equivalent). It provides that: '(1) A person may use such force as is reasonable in the circumstances in the prevention of crime, or in effecting or assisting in the lawful arrest of offenders or suspected offenders or of persons unlawfully at large. (2) Subsection (1) above shall replace the rules of the common law on the question when force used for a purpose mentioned in the subsection is justified by that purpose.'

${ }^{755} \mathrm{Ibid}$, ss (4) 'If D claims to have held a particular belief as regards the existence of any circumstances - (a) the reasonableness or otherwise of that belief is relevant to the question whether D genuinely held it; but (b) if it is determined that D did genuinely hold it, D is entitled to rely on it for the purposes of subsection (3), whether or not - (i) it was mistaken, or (ii)(if it was mistaken) the mistake was a reasonable one to have made.(5) But subsection (4)(b) does not enable D to rely on any mistaken belief attributable to intoxication that was voluntarily induced. (6)
} 
As to forming a legislative offence in the context of assault and battery, the following may be noted:

- In the past, there was self-defence. Also, a person could defend certain others (wife, children, servants, villains) or they him (see 16). By 1904, Kenny was suggesting that this should be extended to any stranger (see 27(c));

- Today, the CJIA 2008, s 76 covers self-defence as well as 'acting in defence of another person', encapsulating Kenny's position.

\section{In conclusion, it is asserted that self-defence and defending others, vis-a-vis assault and battery (as well as in} respect of aggravated offences) should be governed by the CJIA 2008, 576.

\section{(b) Defences - Defence of Property}

\section{Archbold states:}

Reasonable force may be used in defence of property, which includes an entitlement to prevent a trespasser from entering, but the owner of the property must first request the trespasser to depart, before he can justify so much force only as is necessary to move him. ${ }^{756} \ldots$

The right of a landowner to remove a trespasser from his property cannot be extended by analogy to the owner of a motor vehicle removing an unwanted passenger, although it might be open to the owner of a motor vehicle, in the last resort, and when all reasonably practicable alternatives have failed, forcibly to remove an individual who has entered the vehicle without permission and refuses to leave it. ${ }^{757}$

It is important to note that the special provision made for householder cases by the amendments introduced by the Crime and Courts Act 2013, ${ }^{758}$ despite the label, is not concerned with the defence of property, but with 'self-defence.' It remains to be seen whether the courts interpret this as including the defence of others; but it would seem extraordinary that a householder could benefit from a less exacting standard when defending himself, but not if he were defending his infant children, or some other occupant of his household. [one would agree]

As to subsection (5A), the drafting is curious. Whilst it says that force used in a householder case is not to be regarded as reasonable if it was grossly disproportionate in the circumstances as the defendant believed them to be, this applies to any case of self-defence, defence of others, or defence of property. What was intended presumably was that force used in a householder case is only to be regarded as

The degree of force used by $\mathrm{D}$ is not to be regarded as having been reasonable in the circumstances as $\mathrm{D}$ believed them to be if it was disproportionate in those circumstances. (7) In deciding the question mentioned in subsection (3) the following considerations are to be taken into account (so far as relevant in the circumstances of the case) - (a) that a person acting for a legitimate purpose may not be able to weigh to a nicety the exact measure of any necessary action; and (b) that evidence of a person's having only done what the person honestly and instinctively thought was necessary for a legitimate purpose constitutes strong evidence that only reasonable action was taken by that person for that purpose. (8) Subsection (7) is not to be read as preventing other matters from being taken into account where they are relevant to deciding the question mentioned in subsection (3). (9) This section is intended to clarify the operation of the existing defences mentioned in subsection (2). (10) In this section - (a) "legitimate purpose" means -(i) the purpose of self-defence under the common law, or (ii) the prevention of crime or effecting or assisting in the lawful arrest of persons mentioned in the provisions referred to in subsection (2)(b);(b) references to self-defence include acting in defence of another person; and (c) references to the degree of force used are to the type and amount of force used.' Archbold, n 39, para 19-49 states :'Much of what was said in Palmer [see n 748] may be easily adapted to this situation (e.g. as to a person not being able to weigh to a nicety the exact measure of force needed).' See also Lane v Holloway [1968] 1 QB 379 (self defence dis-proportionate).

${ }^{756}$ Archbold, n 39, para 19-239 cites Rolle, n 21, vol 2, p 548, Weaver v Bush (see n 443) and Hussey (see n 594) and the CJIA 2008 , s 76. Archbold also cited $R v$ Faraj [2007] 2 Cr App R 25 (A case of false imprisonment where a service engineer was taken by the householder to be a burglar. Held, on the basis of the defence of his property, a householder was entitled to detain someone in his house whom he genuinely believed to be a burglar, however unreasonable that belief might be, although the defence had its limits and the householder had honestly to believe that he needed to detain the suspect and had to do so in a way that was reasonable). Also, Taylor v Mucklow [1973] Crim LR 750 (whether the use of a loaded gun was a reasonable use of force in all the circumstances carried out by D in the protection of his house. On appeal it was held not, and that - for a person to argue in modern times that a loaded firearm was a suitable way of restraining the kind of bad temper exhibited by the builder [he was building an extension to the man's house] - was to show a lack of appreciation of modern trends). The commentary to this case in the CLR is useful in that it suggests that Hussey (see $\mathrm{n} 594$ ) is no longer good authority.

${ }^{757}$ Archbold, $\mathrm{n}$ 39, para 19-239 cites $R v$ Burns [2010] 2 Cr App R 16 (forcible ejection of a prostitute from a car. The use of force to remove a person at the D's unilateral whim was unlawful. Per Judge CJ at p 120 'we doubt the validity of the analogy between the appellant seeking to remove the complainant from his car and the rights of the house or landowner to remove a trespasser from his property. The court considered that the issue in the present case was more one of self-help'. One would agree.

${ }^{758}$ Section 43 of this Act amended the CJIA 2008, s 76 with s 43(2) providing: '(2) Before subsection (6)(force not regarded as reasonable if it was disproportionate) insert - $(5 \mathrm{~A})$ In a householder case, the degree of force used by $\mathrm{D}$ is not to be regarded as having been reasonable in the circumstances as D believed them to be if it was grossly disproportionate in this circumstances.' The same sub-section then defined 'householder case.' 
unreasonable if it was grossly disproportionate. ${ }^{759}$

In respect of a new statutory formulation, the following may be noted:

- $\quad$ at common law, a person could defend his land and possessions and (like self-defence and the defence of others), providing he acted reasonably, it was a good defence. The only extant requirement at common law in respect of land vis-à-vis this, is that a trespasser generally must request a trespasser to leave first. However, in truth, the latter depends on the circumstances of the case (for example, it is unlikely that a court would insist on it if a person carrying a gun, starts to smash down the door of one's house). Thus, it is asserted that, such a requirement should not be an additional legislative one but should be left to be considered, at trial, with the other circumstances of the case;

- The Crime and Courts Act 2013 (with its amendment to the CIJA 2008) confuses the issue, not least since, as Archbold notes, its purport is not clear. Obviously, it should apply when defending others as well as in the case of self-defence.

In conclusion, it is asserted that the CJIA 2008, s 76 should also cover a person defending his land (including his house) and his possessions, as well as others - providing he acts reasonably.

\section{(c) Defence - Legal Justification}

Archbold refers to the CLA 1967, s $3^{760}$ and the PACE Act 1984, s $117^{761}$ It also states:

It is a good defence that the defendant, as an officer of justice, arrested the prosecutor by virtue of a certain writ of process, if that is the alleged battery complained of. ${ }^{762}$ A sheriff's officer, however, can only justify laying his hand upon a man, in order to arrest him upon a writ of process ${ }^{763}$ unless he resist, or an attempt be made to rescue him, or to prevent or hinder the arrest ${ }^{764}$ and even then he can justify no greater degree of force than was necessary in order to secure the prisoner. ${ }^{765}$

A man may justify laying his hand upon another to prevent him from fighting, or committing a breach of the peace: ${ }^{766}$ or to prevent him from rescuing goods taken in execution ${ }^{767}$ or the like. Yet, even in these cases, he must not use more force than is requisite to restrain the other party, otherwise he cannot avail himself of the threatened breach of the peace etc. as a justification. Serving process by thrusting a document into the fold of a man's coat is not necessarily an assault. ${ }^{768}$

As to the right of a person to resist officers executing civil process, see Southam v Smout [1964] ${ }^{769}$ and Vaughan $v$ Mckenzie [1969] ${ }^{770}$ and the authorities there considered. ${ }^{771}$

\footnotetext{
${ }^{759}$ Archbold, n 39, para 19-48a. Archbold notes, para 19-50, that 'Reasonable force used for such purposes is lawful and it is submitted that the same principles apply as to self-defence. It should be pointed out that the common law rules as to this topic are only superceded by the CLA 1967, s 3 (see n 754) where force is used in the prevention of crime. Acts of trespass are often not criminal. Even when it was thought that to avail himself of the excuse of self-defence a man must have retreated as far as he could when there was no duty to retreat in the face of a trespasser, see $R v$ Hussey [see n 594].'

${ }^{760}$ See $\mathrm{n} 754$

${ }^{761}$ Archbold, n 39, para 19-240 which states: 'See also the PACE Act 1984, s 117 which provides that a constable may use reasonable force, if necessary, in the exercise of any power conferred on him by the Act except such powers as may only be exercised with the consent of some other person, other than a police officer.'

${ }^{762}$ Archbold refers to Rolle, n 21, vol 2, p 547(A).

763 Archbold referred to Harrison v Hodgson (1830) 10 B \& C 445 (109 ER 515)(a person may, under particular circumstances, lay hands on another in order to serve him with process). See also Rose v Kempthorne (1910) 75 JP 71 (order for discovery in the county court was placed in the inner fold of the respondent's coat when he refused to accept it. Alverstone CJ, p 72 'the appellant had before him the respondent, whom he was entitled to serve personally and who would not receive the document, the touching of the respondent was not unnecessary. There really was no evidence that the appellant touched the respondent further than was necessary to bring the document home to him.')

${ }^{764}$ Archbold referred to Truscott $v$ Carpenter and Man (see 348) where the court also stated p 231 'If an officer has a legal process to arrest a man, yet he cannot beat him, unless he resists.'

${ }^{765}$ Archbold referred to Levy $v$ Edwards (1823) 1 C \& P 40 (171 ER 1094) (if a constable is preventing a breach of the peace, and any person stands in his way with intent to hinder him from doing so, the constable is justified in taking such person into custody, but not in giving him a blow).

${ }^{766}$ Archbold refers to Comyns, n 26, (title Pleader), 3 M 16.

${ }^{767}$ Archbold refers to Bridgwater v Bythway (1683) 3 Lev 113 (83 ER 604 )(command by a bailiff to prevent a rescue is not traversable).

${ }^{768}$ Archbold refers to Rose v Kempthorne (n 763).

${ }^{769}$ [1964] 1 QB 308.

${ }^{770}$ [1969] 1 QB 557.

${ }^{771}$ Archbold, n 39, para 19-241.
} 
As noted previously, legal justification has a long history and, indeed, must likely have been extant even at the time of king Aethelbert (see 4(a))( for example, the legal execution of a man would not have been held to have been homicide in the court or executioner). It is asserted that:

- the arrest of a person - as well as the service of legal process (whether criminal or civil) - should be reflected in modern legislation which provides that a person, acting in accordance with due legal process, is acting lawfully (and, therefore, not committing assault or battery) providing he acts reasonably; 772

- this would cover not just the police (and prison officers) but also, for example, persons making a citizen's arrest or when assisting a police (or prison) officer.

In conclusion, the CIJA 2008, s 76 (which covers self-defence etc.) should also cover a person who acts reasonably in accordance with due legal process (whether criminal or civil).

\section{(d) Defence - Lawful Correction: Parents}

Archbold notes the following as to the rights of parents: ${ }^{773}$

- It is a good defence that the alleged battery was merely the correcting of a child by its parents, providing it was moderate in the manner, the instrument and the quantity of it; ${ }^{774}$

- $\quad$ Section 58 of the Children Act 2004 provides that - in relation to an offence under section 18, 20 or 47 of the OPA $1861^{775}$ - battery of a child cannot be justified on the ground that it constitutes reasonable chastisement. $^{776}$

As to this:

- The right of a parent to chastise their child almost certainly derives from the Roman law rights of the father as paterfamilias. ${ }^{777}$ While in the time of Bracton (see 7) this right was (probably) almost absolute $v i s$ - $a$-vis the chastisement of his wife, children, slaves and villains, by the $19^{\text {th }}$ century there was a more benign process involved 778 and it is now restricted to children (beating a wife, servant or apprentice, today, would seem to have no common law protection). And, as to a child, there is no defence where cruelty or actual bodily harm ('ABH') or grevious bodily harm ('GBH') occurs (including death);

- In Scotland, the Criminal Justice (Scotland) Act 2003, s 51 makes it illegal to hit a child with an implement or on the head or to shake a child by way of punishment - although it still retains the concept of 'justifiable consent' (in which defence would fall smacking, for example). ${ }^{779}$

\footnotetext{
${ }^{772}$ Legislation should re-posit the CIJA 2008, s 76 to reflect the fact that no crime has been committed, as opposed to a crime being committed but there being a defence.

${ }^{773}$ Archbold, n 39, para 19-237.

${ }^{774}$ Archbold refers to Hawkins (see 15) and $R v$ Hopley (1860) 2 F \& F 202 (175 ER 1024)(boy beaten with a rod until he died). Per Cockburn $\mathrm{CJ}$ at p 206 'A parent or schoolmaster (who for this purpose represents the parent and has parental authority delegated to him), may for the purpose of correcting what is evil [i.e. misbehaviour] in the child inflict moderate corporal punishment, always however, with this condition, that it is moderate and reasonable.' See also Carter, $\mathrm{n} 749$, pp 41-2 and Bracton, $\mathrm{n} 136$. Also, $R v$ Wall (1802) 28 ST 145 per MacDonald CB cited in Paterson, n 477, vol 1, pp 297-8.

${ }^{775}$ Section 58 also referred to the Children and Young Persons Act 1933, s 1 (cruelty to persons under 16). Halsbury Statutes (4 ${ }^{\text {th }}$ ed), vol 6(1), p 129 refers to a Review of section 58 of the Children Act 2004 (October 2007, Cm 7232) which noted: 'Following the enactment of s 58, the defence of reasonable punishment cannot be used unless the defendant is charged only with common assault, the victim is a child and the defendant is the parent of the child or a person acting in loco parentis.'

${ }^{776}$ Section 58(3) also provides that 'Battery of a child causing actual bodily harm to the child cannot be justified in any civil proceedings on the ground that it constituted reasonable punishment.'

${ }^{777}$ See ns 214-6.

${ }^{778}$ For the developing cases see ns 774 and 781.

${ }^{779}$ Section 58 'Where a person claims that something done to a child was a physical punishment carried out in exercise of a parental right or of a right derived from having charge or care of the child, then in determining any question as to whether what was done was, by virtue of being in such exercise, a justifiable assault a court must have regard to the following factors - (a) the nature of what was done, the reason for it and the circumstances in which it took place; (b) its duration and frequency; (c) any effect (whether physical or mental) which it has been shown to have had on the child; (d) the child's age; and (e) the child's personal characteristics (including, without prejudice to the generality of this paragraph, sex and state of health) at the time the thing was done. (2)The court may also have regard to such other factors as it considers appropriate in the circumstances of the case. (3) If what was done included or consisted of - (a) a blow to the head; (b) shaking; or

(c) the use of an implement, the court must determine that it was not something which, by virtue of being in exercise of a parental right or of a right derived as is mentioned in subsection (1), was a justifiable assault; but this subsection is without prejudice to the power of the court so to determine on whatever other grounds it thinks fit. (4) In subsection (1), "child" means a person who had not, at the time the thing was done, attained the age of sixteen years...'
} 
It is asserted that, in modern legislation, it should be unlawful for a person to commit Violent Assault (i.e. battery) or Attempted Violent Assault (i.e. assault) on a child. Further, it would seem appropriate that the law in Engalnd and Scotland be the same - with it still being lawful for a parent to correct their child in a moderate manner, the precise circumstances then being left to the courts. ${ }^{780}$

In conclusion, it is asserted that the law in the UK should be the same in this matter. Further, lawful correction should not include where a Violent Assault (i.e. battery) or Threatened Violent Assault (e.g. assault) or aggravated assault occurs (including homicide). In due course, smacking may be made unlawful - with the result that this defence will not be needed. The law on assault and battery can then be the same for a child as for an adult (not being criminal, if minor).

\section{(e) Defence - Lawful Correction: Teachers}

Archbold notes the following:

- The relationship between a teacher and a pupil formerly carried with it the right of reasonable chastisement; ${ }^{781}$

- Section 548 of the Education Act 1996 provides that corporal punishment given by (or on the authority of) a member of staff to a child (i.e. a person under 18) for whom education is provided at any relevant institution (i.e. a school or independent educational establishment other than a school) or under an arrangement made by a local authority or for whom special nursery education is provided otherwise than at a relevant institution, cannot be justified in any proceedings on the ground that the it was given pursuant to a right exercisable by a member of staff by virtue of his position as such,. This applies whether the punishment is administered at the relevant institution or elsewhere, ${ }^{782}$

- Corporal punishment in prisons was abolished by the Criminal Justice Act 1967, s $65 .^{783}$

It is asserted the position of teachers - who have always (since Roman times) acted in loco parentis - should be the same as in respect of parents, re the correction of children (see (d) above). So too, in the case of others acting in loco parentis (step parents, baby sitters etc.), in order to prevent any mis-match.

\section{(f) Defence - Consent - Games}

Archbold notes the following: ${ }^{784}$

Games. On a charge of common assault, it is necessary for the prosecution to prove absence of consent. ${ }^{785}$ Where ABH or GBH or a wound is caused, however, consent will be no defence in the absence of a good reason. As to the latter, the Court of Appeal in Att-Gen's Reference (No 6 of 1980) ${ }^{786}$ instanced 'properly conducted lawful games and sports, lawful chastisement or correction, reasonable surgical, dangerous exhibitions etc. ${ }^{, 787}$ In respect of injuries caused in the course of sporting events, Archbold refers to $R v$ Barnes ${ }^{788}$ and discussion therein as to the 'starting point'; ${ }^{789}$

\footnotetext{
${ }^{780}$ See $R v$ Mackie [1973] Crim LR 54 (smacking child on the bottom).

${ }^{781}$ Archbold cites Cleary $v$ Booth [1893] 1 QB 465 (authority delegated by the parent of a pupil to a schoolmaster to inflict reasonable personal chastisement upon him is not limited to offences committed by the pupil upon the premises of the school, but may extend to acts done by such pupil while on the way to, and from, school). Mansell v Griffin [1908] 1 KB 160 (an assistant teacher in a public elementary school has authority to inflict corporal punishment on a pupil, if moderate, if it is not dictated by any bad motive and is such as is usual in the school and such as the parent of a child might expect that the child would receive if it did wrong, and the fact that, by the regulations of the school, assistant teachers are forbidden to inflict corporal punishment will not, of itself, render the assistant teacher liable to an action by the pupil for assault). $R$ $v$ Newport (Salop) JJ exp Wright [1929] 2 KB 416 at pp 427-8 (Boys canned for smoking in the street. JP's found that the father of the boys, by sending them to the school, authorised the master to administer reasonable punishment for breaching the school rules. Hewart CJ made some observations).

${ }^{782}$ Archbold refers to para 19-44 (use of force in schools etc.).

${ }^{783}$ Archbold, n 39, para 19-185. See also Clerk \& Lindsell, n 723, para 15-129-32.

${ }^{784}$ Ibid, para 19-233. See also Re F (see n 631), p 70, per Lord Griffiths 'Although the general rule is that the individual is master of his own fate the judges through the common law have, in the public interest, imposed certain constraints on the harm that people may consent to be inflicted on their bodies.' See also Stephen, $\mathrm{n} 42$, (writing in 1883) art 206 (right to consent to bodily injury short of maim), art 207 (no right to consent to infliction of death), art 208 (no right to consent to injury constituting a breach of the peace), art 209 (consent to be put in danger)

${ }^{785}$ Archbold refers to Brown (see n 631).

${ }^{786}$ [1981] QB 715.

${ }^{787}$ At pp 719, 66.

${ }^{788}$ [2005] 1 Cr App R 30.
} 
Horseplay. In reliance on the 'etc.' and certain dicta in Donovan ${ }^{790}$ the Court of Appeal in Jones (T) 791 added rough and undisciplined horseplay to the list - provided there was no intention to injure. Furthermore, the court pointed out that - even if consent was absent - a genuine belief it was present was constitute a defence. Jones $(T)$ was applied in the context of RAF officers taking part in 'mess games' in Aitken. ${ }^{792}$

In relation to games, it is instructive to consider the early history since it is asserted this exception is in danger of being mis-construed and the only issue for both games and horseplay which the courts need consider is: Did the person, intentionally or recklessly cause other than a minor physical injury ? (if not, but the person did so negligently or accidentally, this is a matter for the civil and not criminal courts).

- Anglo-Saxon \& Anglo-Norman Law. There is no evidence that early English law permitted any form of game in which the death - or serious injury - of a person was the purpose. Further, the legal tariff of wounds, which prevailed from the $6^{\text {th }}$ century until c. 1189 , does not suggest any defence on that basis. That said, under Anglo-Saxon law, all citizens were required to undertake a three-fold obligation (trinoda necessitas) which included defending the country in time of war. Likely, war games (martial exercises) were undertaken as part of being ready for the same and, one presumes, that deaths and injuries sustained in such games were treated as accidental. After the Norman Conquest of 1066, land was held by way of military tenure. Thus, it is likely the same situation prevailed;

- $\quad$ Tournaments. That is, staged martial exercises, seem to have developed at the end of the $11^{\text {th }}$ century (see Appendix G). Although their purpose was not the death or serious injury of the participants - but their capture and ransom for money - the Catholic church prohibited them in 1130 because death or serious injury often occurred (and, in many cases, they may well have been used to settle, by violent means, private feuds). Various English kings also did the same since, often, 'breaches of the peace' arose at such tournaments (whether from the participants or those attending). A charter of Richard I of 1194 subsequently licensed tournaments to 5 specific locations in England - in order to ensure that breaches of the peace did not occur. The policy of Crown licensing then followed (see Appendix G);

- Duels \& Prize Fights. In conclusion, tournaments - and, later, duelling and prize fights - were all held to be unlawful because their purpose (i.e. intent) or their usual consequence was the death or serious injury of a participant, being a breach of the peace. This principle, it is asserted, still prevails (and there have been no Crown licenced tournaments since the $17^{\text {th }}$ century, at least). Given this, no legal tournament, duel or prize fight can presently occur - since they are likely, by their nature, to give rise to a breach of the peace. That is, serious injury (battery) to the participants or commotion among the spectators. Further, and more particularly, no rules of any organised game (or horseplay) can permit the death, or serious injury, of a participant since there is (and never has been) such a defence under English law. Consent cannot override the criminal law - unless legislation so provides;

\footnotetext{
${ }^{789}$ Archbold, n 39, para 19-233, continues: 'that: (i) in determining what the approach of the court should be as when it is appropriate for criminal proceedings to be instituted in respect of such injuries, the starting point is the fact that most sporting events have their own disciplinary procedures for enforcing their particular rules and standards of conduct; as a result, in a majority of situations there is not only no need for criminal proceedings, but it is undesirable that there should be any, prosecution should be reserved for those situations where the conduct is sufficiently grave to be properly categorised as criminal; (ii) although consent is generally irrelevant when bodily harm is caused, as a matter of public policy there are certain exceptions, which include physical injury sustained in the course of contact sports; if what occurs goes beyond what a player can reasonably be regarded as having accepted by taking part in the sport, this indicates that the conduct will not be covered by the defence; though what is implicitly accepted in one sport will not necessarily be covered by the defence in another sport; (iii) that fact that play is within the rules and practice of the game, will be a firm indication that what has happened is not criminal; in making a judgment as to whether conduct is not criminal or not, it has to be borne in mind that, in highly competitive sports, conduct outside the rules can be expected to occur in the heat of the moment, and even if the conduct justifies not only being penalised but also a warning or even a sending off, it still may not reach the threshold required for it to be criminal; that level is an objective one, and does not depend upon the views of individual players; the type of sport, the level at which it is played, the nature of the act, the degree of force used, the extent of the risk of injury, and the state of mind of the defendant are all likely to be relevant in determining whether the defendant's actions go beyond the threshold; and (iv) where a judge used the concept of 'legitimate sport' in his summing up, but failed to identify what was and what was not 'legitimate' in the context of the relevant sport, and failed generally to give the jury the assistance required in order to determine the issues, the conviction was unsafe...' See also $R v$ Billingshurst [1978] Crim LR 553(during a rugby match and in an off the ball incident, B punched G (the opposing scrum half) in the face, fracturing his jaw in two places. He was charged under the OPA 1861, s 20 and convicted).

790 See n 541

791 (1986) 83 Cr App R 375 (tossed other boys in the air but failed to catch them).

792 (1992) 95 Cr App R 304 (RAF mess game, set fire to fire resistant clothing of officer who treated it as a joke. Suffered severe burns. Convictions contrary to section 20 of the OPA 1861 quashed because of a mis-direction on consent and belief in consent, it having been accepted that there had been no intention to cause injury). Archbold also refers to $H v C P S$ [2012] QB 257 (assault on a special needs teacher).
} 
- Martial Law. Thus, the only situation (it is asserted) today that the intentional (or reckless) killing or serious injury of a person is permitted is in the case of war (civil or foreign) ${ }^{793}$ where military (martial) law applies and the courts of justice are 'closed" ${ }^{794}$ In such a situation it is not unlawful to kill an enemy (or a subject who has openly shown diffidatio) on the battlefield. ${ }^{795}$ However, martial law does not exist during peacetime; ${ }^{796}$

- Modern Games. Against this background, all modern games need to be considered. Unlike tournaments, duelling and prize fights, the purpose or intent of modern games is not the death (or serious injury) of the player. Nor do the rules of any of them provide for the same. The purpose and intent of all of them is to win the game - by scoring points etc. This applies universally to games such as tennis, squash etc. as well as to 'rougher' games such as football, rugby and boxing. Given this, it is asserted that modern games do not detract from the basic proposition of law that it is a criminal offence to intentionally (or recklessly) batter another, when the injury is other than minor or can be taken to be part of everyday normal activity. Consent cannot override this. Thus, the infliction of any intentional or reckless major injury is a crime - but not where it is negligent (although it may be a tort) or purely accidental. The same applies to horseplay.

Thus, some of the modern judicial analysis on games and horseplay (it is asserted) is mis-conceived.

- Consent was never the issue in the case of the early law on battery and Pulton (in 1609) as well as other legal writers referred to it as a short-hand means of accepting that minor injuries were not subject to the criminal law. Nor where there was no intent to commit a breach of the peace (i.e. to batter another);

- Given this, consent in the case of games and horseplay (as well as sexual play) is not a true 'defence' of the same ilk as self-defence etc. (where the assault or battery is to prevent a breach of the peace).

Thus, 'consent' is of little relevance since the only issue for the court to consider is whether there was an intent (or recklessness) to inflict other than minor physical injury. Thus, games (and horseplay) are simply forms of everyday human activity which assault and battery are incidents of, when minor.

In conclusion, it is asserted that games and horseplay are no different to the general law on assault and battery. If the same is not minor, and it is intentional (or reckless), no amount of 'consent' can permit it. The rationale for this is that no person can 'contract' out of the criminal law. The 'policy' reason behind this is that, to permit the same, would likely engender 'breaches of the peace' (crimes) leading to the subversion of the criminal law as such. The only exception today which permits intentional, or reckless, physical injury to another is martial law during wartime (leaving aside international Conventions concerning military activity abroad).

\section{(g) Defence - Sexual Consent}

Archbold notes that the satisfaction of sado-masochistic desires does not constitute good reason for the infliction of bodily harm or a wound. ${ }^{797}$ One would agree - where the physical injury is intentionally (or recklessly)

\footnotetext{
${ }^{793}$ See GSMcBain, Abolishing Obsolete Prerogatives relating to Martial Law, Conscription and Billeting (2012) International Law Research, vol 1, no 1, pp 13-62.

${ }^{794}$ Ibid, p 25 quoting Hale CJ that martial law is not permitted 'in time of peace, when the ordinary courts of justice are open.' See also Coke, n 32, vol 3, p 52 .

${ }^{795}$ Civil war (until the final civil war in England in 1745) was very clear as to when a person owing allegiance was put outside the law and could be killed. The (war) standard of the sovereign was raised (explicatio vexilli regis) to signify that the courts were now closed to justice. A person then had to openly confront it (diffidatio). In so doing, that person as well as committing high treason could also be treated as a foreign enemy. See also GS McBain, Abolishing the Crime of Treason (2007) 81 ALJ p 99, fn 53 and GS McBain, Expanding DemocracyTransferring the Crown Prerogative to Parliament (2014) Review of European Studies, vol 6, no 1, pp 27-8 (mode of declaring war).

796 This was confirmed by the Petition of Right 1627 (still extant).

${ }^{797}$ Archbold cites Brown (see n 631) and Laskey, Jaggard and Brown v UK [1997] 24 EHRR 39 (the prosecution and conviction of the appellants (men of full age) for offences contrary to sections 20 and 47 of the 1861 Act in respect of their consensual sado-masochistic activities involved no violation of Article 8 of the ECHR). Archbold continued: 'Brown was distinguished in $R v$ Wilson (A) [1996] 2 Cr App R 244] in which the accused, at his wife's instigation, had branded his initials on her buttocks with a hot knife. There was no evidence that what he did was any more dangerous or painful than tattooing, which, if carried out with the consent of an adult, did not involve an offence contrary to section 47 of the 1861 Act albeit that actual bodily harm was deliberately inflicted; further, there was no aggressive intent. It was not in the public interest that such consensual activity between husband and wife in private should be made the subject of a criminal prosecution; accordingly, in the circumstances, the wife's consent afforded a defence. Wilson itself was distinguished in $R v$ Emmett [Independent, Jan $19^{\text {th }}$, 1999] in which it was held that consent is no defence where the harm caused to the 'victim' consists of more than a transient or trivial injury. As in Wilson, the prosecution was concerned with injuries caused during the course of consensual sexual activity. Whilst the injuries were certainly not trifling, there was no intention on the part of either participant that they should be suffered. They were unintended consequences of the consensual participation of both parties in high-risk activity. The court regarded itself as bound by Brown, but it must be doubtful that the
} 
inflicted and it is other than minor. This has always been the common law (save that recklessness was accepted, for the purposes of the criminal law, in the $20^{\text {th }}$ century). As a result, it is asserted that:

- Brown, and other cases involving sado-masochism, ${ }^{798}$ have given undue attention to emotional aspects deriving from the infliction of injury (i.e. pleasure or pain to the assailant or the victim - whether sexual or otherwise). Such aspects have no prior legal history and they would not have been treated as relevant in past centuries by the courts (indeed, in Anglo-Saxon times, the tariff was not motive based - a death or injury had to be compensated regardless of the reason, criminal or otherwise, for its occurrence);

- As with the situation concerning games, English criminal law has never permitted the intentional (or reckless) infliction of serious injury - whether for the purpose of sport (sexual or otherwise) unless this has been specifically licenced by the Crown (in the case of tournaments) or permitted by legislation. This situation still prevails.

In conclusion, no intentional or reckless battery (i.e. infliction of a physical injury other than a minor one) whether arising from sexual activity or otherwise - is lawful, unless permitted by legislation.

\section{(h) Defence - Medical Treatment}

\section{Archbold notes that: ${ }^{799}$}

- It is a battery to perform physically invasive treatment without a patient's consent. A mentally competent patient has an absolute right to refuse consent to medical treatment for any reason, rational or irrational - or for no reason at all - even where that decision will lead to his death. ${ }^{800}$ There is no requirement to explain the 'possible major consequences' together with the 'options' and 'alternative treatments' in order to negative a battery arising out of a medical procedure;

- It is sufficient that the patient consents to the procedure having been advised in broad terms of its nature. A failure to advise as to the consequences or alternatives might expose the practitioner to a suit in negligence. However, it will not vitiate consent. ${ }^{801}$

It is asserted that:

- In early times, surgery or medical attention to the human body was not viewed as a battery (a wound) and was not treated as falling within the tariff of wounds which prevailed until c. 1189 since it was therapeutic (i.e. healing a wound rather than creating one). Therefore, there was no intent to commit a breach of the peace. This situation should still prevail. Thus, a person cannot consent to mutilation which is not therapeutic, since the English criminal law (in the absence of legislation) has never permitted it; ${ }^{802}$

- A patient can refuse medical treatment, since it has never been unlawful for a person to refuse medical treatment. In the case of a person unable to consent, it is asserted that consent is given on their behalf by the court (or other party) not as a consent to a battery but rather as a consent to a therapy (the same not, ipso facto, being a battery) and this on the basis that a reasonable person would consent to medical treatment intended to save their life or improve their health.

\footnotetext{
decision in Brown would have been the same had their Lordships been concerned with the unintended consequences of consensual activity.' One would assert that the issue in these cases of sexual activity is no different to any other activity, sports included. If it results in death - or other than minor battery - it is a criminal act (in old fashioned terminology, it results in a breach of the peace).

798 e.g. Emmett (1999) Times, 15 October (serious injuries from lighter fuel as a result of consensual sado-masochistic acts).

${ }^{799}$ For the position in tort, see Deakin, n 723, pp 363-9 and Clerk \& Lindsell, n 723, ch 15. The principles in tort and the criminal law as to consent to medical treatment would appear to be no different, save in respect of negligence. Stephen, $\mathrm{n} 42$ (writing in 1883) stated as to surgery (ar 204) 'Every one has a right to consent to the infliction of any bodily injury in the nature of a surgical operation upon himself or upon any child under his care, and too young to exercise a reasonable discretion in such a matter, but such consent does not discharge the person performing the operation from the duties hereinafter defined in relation thereto.' (art 205) 'If a person is in such circumstances as to be incapable of giving consent to a surgical operation, or to the infliction of other bodily harm of a similar nature and for similar objects, it is not a crime to perform such operation or to inflict such bodily harm upon him without his consent or in spite of his resistance.'

${ }^{800}$ Archbold cited Re JT (Adult. Refusal of Medical Treatment) [1998] 1 FLR 48 and Re B (adult: refusal of medical treatment) [2002] 2 AE 449

${ }^{801}$ Archbold, $\mathrm{n} 39$, para 19-235, refers to Reeves $v$ The Queen unreported. December 18 ${ }^{\text {th }}, 2013$. HC of Australia [2013] HCA 57. See also Lord Browne-Wilkinson in Airedale NHS v Bland [1983] $1 \mathrm{AE} 821,881$ 'any treatment given by a doctor to a patient which is invasive... is unlawful unless done with the consent of the patient: it constitutes the crime of battery and the tort of trespass to the person.'

${ }^{802}$ Thus, if a person asked a doctor to cut off their arm (or to perform an operation which would result in more than minor physical injury to them) and there was no therapeutic reason for this - the doctor would be committing a battery, regardless of the consent of the patient. See $\mathrm{n} 578$ (case of Wright (1603)). The situation is no different to where a person not a doctor is requested to perform the same.
} 
In conclusion, modern caselaw is in danger of mis-conceiving the nature of medical treatment. Providing that it was therapeutic it has never been taken to be a battery since early times - the intent not being to wound (but to cure a wound). Also, with no intent to commit a breach of the peace.

\section{(i) Apparent Consent}

Finally, Archbold notes that:

- Suspension of Medical Practitioner. A patient's ignorance of the fact that the dentist who treated him was suspended from practice did not vitiate the patient's consent to treatment so as to make the dentist guilty of assault. There would be assault only where there was consent to the actions of another in the mistaken belief that they (or he) were other than they truly were (the common law not being concerned as to the reason for the mistake). The concept of the identity of the person was not to be extended to cover the qualifications or attributes of the person. To do so would be to extend the everyday meaning of identity; ${ }^{803}$

- $\quad$ Tattooing. In Burrell v Harmer ${ }^{804}$ a conviction for assault followed the tattooing of two boys aged 12 and 13. The court observed that, if a child of the age of understanding was unable to appreciate the nature of an act, consent to it was no consent at all. ${ }^{805}$

In conclusion, it is asserted English criminal law has permitted, for many centuries at least, reasonable (i.e. proportionate) assault and battery arising from self-defence, defence of others and defence of a person's land and possessions - on the basis that it is preventative. That is, it is designed to prevent (pre-empt) a breach of the peace (i.e. a breach of the criminal law). However, it is asserted English criminal law has never permitted the infliction of an intentional (or reckless) physical injury on another person of more than a minor nature whether consensual or not - and as to supposed exceptions (defences) to this the following should be noted, since there is a danger that modern analysis is mis-construing the position:

- The physical correction of a child was permitted - if moderate - since no breach of the peace of the peace was intended (and/or it was minor);

- All medical treatment (including surgery) was treated as therapeutic and, thus, not the infliction of a physical injury (a wound). Further, no breach of the peace was intended;

- Physical injury sustained in games - whether organised games or horseplay or sexual - are the same, $r e$ the infliction of injury. If intentional or reckless battery occurred and it was not 'minor' (that is incidental to everyday human activity) it was a crime (a battery) - unless the common law permitted otherwise (when martial law applied) or where legislation permitted it. This should be the law today. Thus, the implied 'consent' accorded in the playing of games etc. is no different to the implied consent accorded in the case of any other everyday human activity which gives rise to minor injuries. In short, there is (and should be) no separate legal category of consent vis-à-vis games, whether organised or not (i.e. horseplay) or sexual activity;

- In past centuries, tattooing (which was very common in Anglo-Saxon times) was not treated as a 'wound' as such. Further, there was no intent to commit a breach of the peace. Tattooing is now regulated by legislation;

- In past centuries, male circumcision was not generally practiced in the UK and, if so, it would likely have been treated (from the $17^{\text {th }}$ century onwards) as a 'minor' wound and, thus, not subject to the criminal law. Today, this issue may need to be legislatively provided for since, given changing social perceptions, it might well be now regarded as a form of mutilation ${ }^{806}$ save, possibly, where it is a long established religious practice. ${ }^{807}$

\footnotetext{
${ }^{803}$ It cited $R v$ Richardson [1998] 2 Cr App R 200 (Appellant was charged with 6 counts of assault occasioning ABH when continuing to work as an disqualified dentist. It was held that fraud only negatived consent, if the victim was deceived as to the identity of the person concerned or the nature of the act performed. The concept of 'identity of the person' could not be extended to cover the qualifications or attributes of the appellant. There was no basis for finding criminal liability). Cf. Tabassum [2000] 2 Cr App R 328.

${ }^{804}$ [1967] Crim LR 169.

${ }^{805}$ Archbold, $n$ 39, para 19-236 notes:'Tattooing is now regulated by the Tattooing of Minors Act 1969; it is a summary offence to tattoo a person under the age of 18 , subject to an exception for doctors tattooing for medical reasons.'

${ }^{806}$ In early times, the view of the (Christian, Catholic) church in England on this, would have been important, re the judicial position. For example, a Penitential of (it is said) Theodore, Archbishop of Canterbury (668-90) held any mutilation of the human body (including emasculation for religious reasons a la Origen) was a serious sin requiring penance. See Thorpe, $\mathrm{n} 6$, index (wounding, if a person voluntarily cut off one of his limbs or virilia sua). Also sins requiring penance were: (a) if anyone wound his father or mother; (b) if anyone strike another
} 


\section{Defences in Legislative Form}

The types of defences to assault and battery (as well as to aggravated assaults and death) have not changed in 500 years. What has happened is that they have become simplified, although this is difficult to perceive in the cross-references Archbold makes to homicide, aggravated offences and assault and battery. It is asserted that - to preserve coherency and ease of reference - these defences should now be set out in legislative form. Further, they should not be defences. ${ }^{808}$ Rather, it should be a case of 'no crime (assault or battery) committed'. Thus, it is asserted that:

- Self Defence, Defence of Others, Defence of Land \& Possessions, Legal Justification. The CJIA 2008 , s 76 should cover all these and the issue should be whether D's conduct was 'reasonable' (the word 'proportionate' is the same, although less easily understood); 809

- Lawful Correction. The position re parents and those acting in loco parentis (including teachers) should be the same, throughout the UK. Physical correction should be permitted, but not where it results in a Violent Assault (i.e. battery) or any aggravated offence;

- Surgery. It should be lawful for a medical practitioner to perform therapeutic surgery or other medical treatment where consent is given - or held to be given (in the case of an emergency, court order etc.);

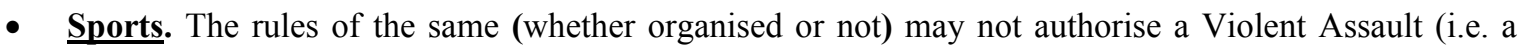
battery) or an aggravated offence.

\section{Aggravated Assaults \& Batteries}

There are still extant a number of common law, and legislative, crimes in respect of aggravated assault. Prior to analysing them, the following may be noted:

- Under Roman law there was a concept of injuria that was aggravated (atrox) - with the result that the punishment imposed was greater. What made the injuria, atrox was, in part, the severity of the wound or the status (dignity) of the person attacked or the location where a person was attacked (such as in the forum or theatre)(see 3);

- Similarly, under Anglo-Saxon and Anglo-Norman law, various batteries resulted in a higher fine. viz. where it incapacitated a man from fighting (mayhem) or it was directed against the sovereign (or another important person) or it took place in a particular location (such as in the sovereign's presence, his palace or his courts)(see 4);

- Under the above laws, the aggravation went to the punishment and not to the substantive offence. This point was lost sight of under later English law - likely because the legislation often used different wording when describing the offence. ${ }^{810}$ Given this, it is asserted that the modern aggravated offences should be no different to assault and battery - apart from in relation to the punishment or where this is descriptively necessary. ${ }^{811}$

It is asserted that there are four aggravated offences which are obsolete and which should be repealed. These comprise: (a) drawing a weapon in court; (b) rescuing a prisoner from court; (c) striking (or offering violence to) a minister of religion; (d) assaulting (striking or wounding) any JP or other person in respect of wreck. It may be

with a stick or stone; (c) if anyone disable another in a quarrel; (d) if a man wound another; (e) if anyone strike another and do not injure him; (f) if children (or youths) strike each other so as to shed blood; (g) if anyone wound (or disable) another in anger; (h) if an ecclesiastic wound a man; (i) if anyone shed boiling water over another so that he die: (j) if anyone wound a clerk (or priest); (k) if anyone strike (or shed) blood. One would assert that circumcision (male or female) would have been treated as a mutilation since it was only practiced re males by those of the Jewish and not of the Christian faith. See also M Lapidge, Archbishop Theodore (Cambridge UP, 1995), pp 141-74. See also www.amglo-saxon.net/penance (AJ Franzen), for other penitentials.

807 The issue of Jewish circumcision in England would have been of little relevance in early times since the first record of Jewish settlement in England is said to have been in 1070. The Jews were expelled by an edict of Edward I (1272-1307) in 1290 and they are not thought to have been present again in the country until c. 1656 (where there was found to be a small colony of Sephardic Jews in London whom Oliver Cromwell permitted to stay). That said, Bracton (writing c. 1240), n 10, vol 2, p 408 clearly thought that circumcision was a crime (on par with castration) save in the case of the Jewish religion. 'The jews are allowed to circumcise their sons but those of other religions are not; if they do so the punishment for castration is imposed.'

${ }^{808}$ Thus, for example, assaults and batteries which are impliedly consented to, as part and parcel of everyday human activity, should be treated as lawful - rather than a crime for which there is a valid defence. For problems with defences generally, see JC Smith, Justification and Excuse in the Criminal Law (Stevens, 1989).

${ }^{809}$ This would require relatively little amendment to the CJIA 2008, s 76.

${ }^{810}$ For example, in the case of $\mathrm{ABH}$ and $\mathrm{GBH}$, see $\mathbf{4 3}$ for the Victorian legislation and wording.

${ }^{811}$ For example, in the case of a person assaulting a police officer acting 'in the execution of his duty.' See $\mathbf{4 2}$. 
noted that the CLRC considered (in 1980) that all such special offences should be abolished and that the LC (in 1992) agreed with this. ${ }^{812}$

\section{(a) Court: Drawing a Weapon or Rescue}

Fighting in the sovereign's presence merited severe punishment from early times. This was then extended to his palace and to his courts. ${ }^{813}$

- Under the English common law, the offence of contempt still exists and it includes an offence where a person 'draw a weapon upon any judge, or justice, though he strike not.' ${ }^{814}$ Hawkins placed this crime within the generic crime of 'contempt of the sovereign'; ${ }^{815}$

- Another crime of similar ilk is to rescue a prisoner before certain courts. ${ }^{816}$

In previous articles, it has been asserted that these crimes (as well as the generic crime of contempt of the sovereign) are obsolete and that they should be abolished. ${ }^{817}$

\section{(b) Obstructing a Minister of Religion}

The OPA 1861, s 36 (which concerns obstructing or assaulting a clergyman or other minister in the discharge of his duties) provides that it is a misdemeanour:

Whosoever shall, by threats or force, obstruct or prevent or endeavour to obstruct or prevent, any clergyman or other minister in or from celebrating divine service or otherwise officiating in any church, chapel, meeting house, or other place of divine worship, or in or from the performance of his duty in the lawful burial of the dead in any churchyard or other burial place, or shall strike or offer any violence to, or shall, upon any civil process, or under the pretence of executing any civil process, arrest any clergyman or other minister who is engaged in, or to the knowledge of the offender is about to engage in, any of the rites or duties in this section aforesaid, or who to the knowledge of the offender shall be going to perform the same or returning from the performance thereof... ${ }^{818}$

Neither Halsbury ${ }^{819}$ nor Archbold ${ }^{820}$ mention any caselaw in respect of the wording in italics, which relates to assault and battery. ${ }^{821}$

\footnotetext{
${ }^{812}$ See n 635, p 42.

${ }^{813}$ See $\mathrm{n} 86$ (for Anglo-Saxon law). For the Laws of Henry I (c.1113), see Downer, n 8, p 119 'Anyone who fights in the king's dwelling shall forfeit his life.' See also Russell (writing in 1819), n 38, vol 1, pp 875-9.

${ }^{814}$ Coke (published in 1641), n 32, vol 3, p 140 'If any man in Westminster hall, or in any other place, sitting the courts of chancery, the exchequer, the kings bench, the common bench, or before justices of assize, or justices of oier and terminer... shall draw a weapon upon any judge, or justice, though he strike not; this is a great misprision, for the which he shall lose his right hand, and forfeit his lands and goods, and his body to perpetual imprisonment: the reason hereof is, because it tendeth ad impedimentum legis terrae [to impede the law of the land]. So it is, if in Westminster hall or any other place, sitting the said courts there, or before justices of assise, or oier and terminer, and within the view of the same, a man doth strike a juror, or any other with weapon, hand, shoulder, elbow, or foot, he shall have the like punishment; but in that case, if he make an assault, and strike not, the offender shall not have the like punishment.' See also GS McBain, Abolishing some Obsolete Common Law Crimes (2009) 20 KLJ, pp 98-102.

${ }^{815}$ See McBain, n 814, p 100. Also, McBain, n 5, pp 167-8.

${ }^{816}$ Coke, n 32, vol 3, p 140 stated: 'If any do rescue a prisoner in or before any of the aforesaid courts committed by any of the aforesaid justices, it is a great misprision, for which he and the prisoner assenting to it, shall forfeit their lands and goods, and their bodies to perpetual imprisonment, but shall not lose the right hand, because no stroke or blow was given.'

${ }^{817}$ See ns 5 \& 814 .

${ }^{818}$ The punishment is a term not exceeding 2 years imprisonment. See Archbold, $\mathrm{n} 39$, para 19-249. For a specimen indictment see Archbold (1992 ed). See also Matthew v King [1934] 1 KB 505 (re meaning of divine service). CS Greaves, The Criminal Law Consolidation and Amendment Acts $\left(2^{\text {nd }}\right.$ ed, 1862), p 64 'This clause is new in England, except that part which applies to the arrest of any clergyman while performing divine service, or going to perform the same, or returning from the performance thereof, which was contained in both the 9 Geo 4 , c 31, s 23 [1828] and 10 Geo 4, c 34, s 27(I) [1829]. The rest of the clause is framed on the Irish Acts of the 27 Geo 3, c 15, s 5; 40 Geo 3, c 96 , s 5, Geo 4, c 25, s 5; and 5 Vict, sess 2, c 28, ss 7, 19. The amendments consist in including ministers not of the Church of England and Ireland, and all places of divine worship, and all burial places, and in adding the endeavour to prevent or obstruct, the offering any violence to, and the arrest under pretence of executing any civil process of, any clergyman or minister engaged in or about to engage in any of the rites or duties mentioned in this clause.'

${ }^{819}$ Halsbury (5 $5^{\text {th }}$ ed), n 48, vol 12(1), p 149.

${ }^{820}$ Archbold, n 39, para 19-310.

${ }^{821}$ Cf. $R$ v Cheere (1825) 4 B \& C 902 (107 ER 1294)(obstruction of a clerk. However, this was not under s 36).
} 
- The precursors to this offence lie in early pieces of legislation referred to by Pulton (writing in 1609) namely, an Act of 1376 (an offence to arrest one in a church during divine service) ${ }^{822}$ and the Brawling Act 1553 (an offence to disturb a preacher in his sermon). ${ }^{823}$ These Acts have now been repealed;

- An Act of 1315 also provided that - if a person laid violent hands on a clerk - amends for the peace broken were to be before the king (i.e. by indictment before the king's courts). It is likely that special damages as well as a suit before an ecclesiastical court could also be sought. ${ }^{824}$ This Act has been repealed. ${ }^{825}$

It is asserted that the wording in italics in s 36 above in respect of clergyman is not necessary. Not least, since there appears to have been no case in the last 150 or so years. There is no reason why assault or battery on a clergyman should not now be treated the same as an assault or battery under the general law, something the Law Commission concluded as long ago as 1980 (and 1992). It may be noted that prior Acts which made specific provision for important persons have now been repealed. ${ }^{826}$

\section{(c) Saving Wreck}

The OPA 1861, s 37 (which concerns assaulting a magistrate etc. on account of his preserving wreck) provides that a person is guilty of a misdemeanour:

Whosoever shall assault and strike or wound any magistrate, officer, or other person whatsoever lawfully authorized, in or on account of the exercise of his duty in or concerning the preservation of any vessel in distress, or of any vessel, goods, or effects wrecked, stranded, or cast on shore, or lying under water... ${ }^{827}$ (italics supplied)

Neither Halsbury, ${ }^{828}$ nor Archbold, ${ }^{829}$ refer to a precedent in respect of this offence.

- This offence (and its precursor) must be considered in the context of the scourge of 'wreckers' who prevailed in many coastal parts in past times. They lured ships to their destruction and then plundered the contents of the vessels. They also often murdered the persons on board ship, or prevented them from reaching shore, to preclude them being witnesses to their nefarious activities. And, when law officers,

\footnotetext{
${ }^{822} 50$ Edw 3 c 1 (1376)(rep) continued by 1 Ric 2 c 15 (1377)(rep). Pulton, n 30, p 8 stated: 'Though the law has a regard to preserve peace between all persons, and in all places, and carries a vigilant eye, that one person shall not menace, assault, beat, mayhem, or imprison another (but in certain cases, and for some special causes) and imposes a heavy burden on such all shall break that peace by any of the means aforesaid: yet she has a more special respect to some certain places, to some times, and to some persons; and carries that reverend and due care and consideration of them; that she inflicts a more sharp and bitter punishment on such as shall violate the peace in them, or to the offence of them. And therefore for the avoiding of the disturbance of the peace in church (where God is to be honoured and all peace to be preserved) and to continue peace to priests, clerks, and others, while they are doing divine service, there was a statute made anno 50 E 3 and after rehearsed and continued anno 1 R 2 whereby it was enacted, that if any of the king's officers, or other person, do arrest any priest, clerk, or other, which is doing any divine service in the church, churchyard, or other place dedicated to God, he shall be imprisoned, and punished at the king's pleasure, and further shall recompense the party arrested. But no people of the church, shall keep them within the church, or sanctuary by fraud or collusion.'

${ }^{823}$ See 1 Mar stat 2 c 3 (Brawling Act 1553) (rep). Pulton, n 30, p 8 stated: 'By a like statute made anno 1 reg M [Brawling Act 1553] it was ordained, that if any person of his own authority, shall willingly and of purpose by open words or deeds, maliciously or contemptuously disturb, or by any other unlawful ways disquiet or misuse any preacher allowed to preach by the Queen, or by any archbishop or bishop of this realm...[etc.] in his open sermon, preaching, or collation, that he shall preach or pronounce in any church, chapel, or churchyard, or in any other place used or appointed: then every such offendor [etc.] immediately after any of the said misdemeanours committed, or at any time after [shall be arrested and carried before a JP shall commit him to prison for 3 months etc.]. See Russell, n 38, vol 2, pp 1526-7. See also Williams $v$ Glenister (1824) 2 B \& C 699 (107 ER 543)(detention of parishioner who read out a notice in a church).

${ }^{824} 9$ Edw 2 st 1 c 3 (1315)(rep). See Russell (writing in 1819), n 38, vol 1, pp 79-80 and Hawkins, n 34 (in 1824), pp 117-8.

${ }^{825}$ As to other legislation, Russell (writing in 1819) referred only to the Act of 1315. However, Russell, n 38, (1964 ed), ch 106, referred to the Brawling Act 1553(rep), Places of Religious Worship Act 1812, s 12 (rep, see vol 2, ch 106), Toleration Act 1688 (1 Will \& M c 18), s 18 (rep) and the Ecclesiastical Courts Jurisdiction Act 1860, s 2 (still extant).

${ }^{826}$ e.g. 9 Anne c 16 (1710, assaulting and striking a privy councillor in the execution of his office)(rep), 11 Hen VI c 11 (1433, assaults on lords and MP's)(rep) and 5 Hen IV c 6 (1403, assaults on servants of MP's)(rep). See Russell(writing in 1819), n 38, vol 1, p 879.

${ }^{827}$ The sentence is imprisonment for a term not exceeding 7 years.

${ }^{828}$ Halsbury ( $5^{\text {th }}$ ed), n 48, vol 12(1), p 149.

${ }^{829}$ Archbold, $n$ 39, para 19-312. For a specimen indictment see Archbold (1992 ed). Greaves, n 817, p 65 'This clause is taken from the 9 Geo 4 c 31, s 24 [1828] and 10 Geo 4, c 34, s 30 (I).' [1829]. 'See also 26 Geo II c 19, s 11 (1753)(rep)(assaulting persons on account of their discharge of their duty in the salvage of vessels in distress or of vessels, goods etc. wrecked, stranded etc.), for which see Russell, n 38, vol 1, pp 891-2. Also, Holdsworth, n 168, vol 11, p 536. Other legislation such as 11 \& 12 W 3 c 7 (1698) (persons laying hands on the commander of a ship to hinder him from fighting, to suffer death) and 33 Geo 3 c 67 s 2 9(1793)(obstructing seamen or assaulting them with intent to obstruct and prevent them from pursuing their lawful occupations), have been repealed. See Russell, n 38, vol 1, pp 892-3 which refers to them. See also Hawkins (1824), n 34, vol 1, p 117).
} 
JP's and other officials (such as customs officers) sought to prevent the plundering of wrecks, they were frequently assaulted and wounded;

- Today, thanks to modern navigation, there are few wrecks off the English coasts and wrecked material is rarely of worth in any case. ${ }^{830}$ Further, JP's are no longer involved in duties involving wreck - such matters now being left to the police.

Given this, it is asserted (as did the Law Commission in 1980 and 1992) there is no need for this specific offence. The general law should apply in these (very rare) instances - especially with reference to assaulting police officers in the execution of their duty (see 42). ${ }^{831}$

In conclusion, it is asserted that aggravated assaults relating to: (a) drawing a weapon in court; (b) rescuing persons from court; (c) striking (or offering violence to) a minister of religion; (d) assaulting, striking or wounding any JP etc. re wreck, are no longer required. They should be abolished/repealed.

\section{Other Aggravated Assaults: Resisting Arrest}

The OPA 1861, s 38 (assault with intent to resist arrest etc.) provides that it is a misdemeanour:

Whosoever...shall assault any person with intent to resist or prevent the lawful apprehension or detainer of himself or of any other person for any offence... ${ }^{832}$

The reference to 'assault' is to any assault or battery as previously discussed by Archbold. ${ }^{833}$ Archbold also notes that the 'intent must be to resist or prevent the lawful apprehension of the defendant or another person for any offence' as well as the following:

- Lawful Apprehension or Detainer. It must be proved that the person assaulted had the right to apprehend (or detain) D for any offence. ${ }^{834}$ The words 'for any offence' seem to exclude arrest on civil process and in relation to breach of the peace - but do include contempt of court (whether criminal or civil). ${ }^{835}$ The words 'or detainer' add nothing. ${ }^{836}$ Archbold also notes that the general powers of arrest for officers without a warrant - for both constables and ordinary citizens - are contained in the PACE Act 1984, ss 24 \& 24A; $;^{837}$

- Mistake of Fact. It must be proved that $\mathrm{D}$ assaulted somebody intending to resist (or prevent) what was (or would have been) a lawful arrest for an offence. It does not have to be proved that D was aware of the circumstances which made the arrest lawful - although, in practice, he often will be. ${ }^{838}$

\footnotetext{
${ }^{830}$ See NE Palmer, Interests in Goods (1998), ch 7 (he noted the small worth of wreck reported. For example, in 1990, there were 25 items of which 21 were worthless). Cf. wrecks in the $17^{\text {th }}-18$ th century, see J Vivian, Tales of the Cornish Wreckers (Tor Mark Press, 1989).

${ }^{831}$ The OPA 1861, s 17 which concerns impeding persons endeavouring to escape from wrecks provides for life imprisonment in the case of: 'Whosoever shall unlawfully and maliciously prevent or impede any person, being on board of or having quitted any ship or vessel which shall be in distress, or wrecked, stranded, or cast on shore, in his endeavour to save his life, or shall unlawfully and maliciously prevent or impede any person in his endeavour to save the life of any such person as in this section first aforesaid.' (italics supplied). It is asserted that this clause should be amended to refer to intentional or reckless conduct (as opposed to unlawful and malicious) and that it be placed in shipping legislation.

832 The punishment is imprisonment not exceeding 2 years. See also Archbold, n 39, para 19-316. Greaves, n 818, p 65 'This clause is taken from the 9 Geo 4, c 31, s 25 [1828] and 10 Geo 4, c 34, s 31(I). [1829] This clause extends the former enactments to resisting and willfully obstructing peace officers. Revenue officers were included in the former clause, but are omitted in this, because assaults on them are otherwise provided for.'

${ }^{833}$ Archbold, n 39, para 19-317.

${ }^{834}$ Archbold cites $R v$ Self (1992) 95 Cr App R 42(no valid citizen's arrest was made). See also Halsbury ( ${ }^{\text {th }}$ ed), n 48, vol 12(1), p 150.

${ }^{835}$ Archbold, $n$ 39, 19-319. 'The words 'for any offence' would seem to exclude arrest on civil process and arrest in respect of breach of the peace. Conduct constituting a breach of the peace or giving rise to a fear that a breach of the peace will ensue does not constitute an offence as such. Contempt of court, it is submitted, is an offence for these purposes, whether the contempt is 'criminal' or 'civil'. Archbold then refers to A-G v Newspaper Publishing plc [1988] Ch 333 and Dean v Dean [1987] 1 FLR 517. Cf. Cobra Golf Ltd v Rata (civil contempt is not a criminal offence).

${ }^{836}$ Ibid. 'The words 'or detainer' add nothing to 'lawful apprehension'. It is trite law that there is no power of detention short of arrest for an offence, see Kenlin v Gardiner [see 30]...Whilst there are statutory powers of stop and search (PACE Act 1984, s 1; Terrorism Act 2006, s 44) and whilst the exercise of such powers may lead to an arrest 'for any offence', it cannot be said that when a constable exercises the power of stop and search, he is detaining the person searched 'for any offence.'

${ }^{837}$ It also notes that certain special powers of arrest were preserved by s 26(2) and Sch 2 to the same.

${ }^{838}$ Archbold, n 39, para 19-321 continues 'He could, however, be the totally innocent victim of a case of mistaken identity: the arrest could be lawful, yet he would not know that. If he assaulted the person endeavouring to arrest he would be guilty of the offence. What is the position if the person to be arrested genuinely believes in the existence of circumstances that would make the arrest unlawful or that the person seeking to make the arrest were not in fact police officers? General principles suggest that where a defendant has made a mistake of
} 
This section was taken from prior legislation. ${ }^{839}$ As to the need for this section the following may be noted:

- In earlier times, the legal person of a person making a citizen's arrest was no different to that of a constable (see 42). And a constable's position was no different to that under the general law;

- However, unfortunately perhaps, legislation started to make distinct offences and these were then cobbled together in the OPA 1861, an Act which has been justly criticised. ${ }^{840}$

As it is, it is asserted that assaulting people who make citizen's arrests - or in the case of contempt of court or in the case of both criminal (and civil) process - should be no different to the general law of assault and battery. Thus, is it is asserted that this offence is not required (the Law Commission, in 1992, questioned the worth of its retention). ${ }^{841}$

- However, if retained, this offence should be no different to assault and battery, save as to the punishment;

- Further, any distinction between criminal and civil process - as well as between breach of the peace and other crimes appears quite unnecessary - not least, since there was none in early times. ${ }^{842}$

\section{It is asserted this offence is not required. And, if it is, it should be no different to assault and battery - save as to the punishment.}

\section{Assaulting a Police Officer}

From olden times, constables (also called headboroughs and tithingmen) could act in self-defence and they were protected in so doing. ${ }^{843}$ However, any assault and battery on them was treated no different to any assault and battery under the general law. A more specific indictment then developed, to deal with obstructing constables in the execution of their duty. ${ }^{844}$

- However, there seems to have been no legislative offence of assaulting a police officer prior to 9 Geo 4 c 31, s 25 (1828) and 10 Geo 4 c 34, s 31 (1829). ${ }^{845}$ These sections were later encapsulated in the OPA $1861, \mathrm{~s}_{38}{ }^{846}$

fact his criminality should be judged on the basis of his mistaken view of the facts. Archbold cites Kimber (see 30), Williams (see 30) and $R v$ Beckford [1998] AC 130. The reasonableness or unreasonableness of the defendant's belief is material only to the question of whether the belief was held by the defendant at all. There appears to be no reason why these principles should not apply to an allegation of an offence. Contrary to s 38 the decision of the Court of Appeal in $R v$ Ball (SL) $90 \mathrm{Cr}$ App 378 suggests, however, that they have extremely limited application. See also $R v$ Browne [1973] NI 96, Smith \& Hogan, Criminal Law 13 ${ }^{\text {th }}, 2011$, pp 333-335.'

${ }^{839}$ Greaves, n 818, p 65 'This clause is taken from the 9 Geo 4, c 31, s 25 [1828] and 10 Geo 4, c 34, s 31(I). [1829] This clause extends the former enactments to resisting and willfully obstructing peace officers. Revenue officers were included in the former clause, but are omitted in this, because assaults on them are otherwise provided for.'

${ }^{840}$ As Holdsworth, n 168, vol 15, pp 153-7, pointed out, an act of 1828 (9 Geo IV c 31) consolidated the law, repealing, in whole or part, some 57 Acts from Henry III [1216-72] to George IV [1820-30]. The Act of 1861 was a further consolidation. As to the Act of 1861, Holdsworth correctly states, $\mathrm{p} \mathrm{156,} \mathrm{'The} \mathrm{Act} \mathrm{is} \mathrm{defective} \mathrm{in} \mathrm{that} \mathrm{it} \mathrm{reproduced} \mathrm{the} \mathrm{older} \mathrm{statutes} \mathrm{without} \mathrm{attempting} \mathrm{to} \mathrm{generalize} \mathrm{their} \mathrm{provisions,} \mathrm{thus,} \mathrm{in}$ some cases, retaining distinctions which are meaningless.' See also Brown (see n 631) p 248 per Lord Lowry 'The Act of 1861 was a laudable but untidy Victorian attempt to codify different areas of the law.' He referred to the Law Commission Paper no 122 in 1992 (see n 635), para 7.4 (see $\mathrm{p} 20$. See also further trenchant criticism of the Law Commission of this Act on pp 19 \& 21).

${ }^{841}$ See $\mathrm{n} 635$, pp 43-4.

${ }^{842}$ This offence is closely connected to that of a person assisting a police office in the execution of his duty, see $\mathbf{4 2}$.

${ }^{843}$ See 9(e). See also right of self-defence, see n 202 (Fitzherbert in 1538).

${ }^{844}$ See e.g. W Stubbs \& G Talmarsh, Crown Circuit Companion (Dublin, 1766), p 86 which contains an indictment for a common assault (X 'did make an assault; and him the said JH then and there did beat, wound, and ill-treat, so that his life was greatly despaired of, and other wrongs to the said JH then and there did, to the great damage of the said JH and against the peace of our said lord the king, his crown and dignity.'). Also, one for assaulting a police constable in the execution of his duty (X 'in and upon one JW (then being one of the constables of the said parish of [ ]) in the peace of God, and our said lord the king, and in the due execution of his said office, then and there being, did make an assault, and him, the said JW then and there did beat, wound, and ill-treat...).' A side note indicates 'In this, and all cases of the like nature, 'tis necessary to add this count. That if it should not be proved that the prosecutor was in the due execution of his office, the defendant may be convicted for a common assault, for the jury may find only as to the latter count, if the former count is not fully proved; but when 'tis fully proved, the jury finds the defendant guilty in general.'

${ }^{845}$ See also Russell (last edition, 1964), n 39, vol 1, p 687. Section s 25 referred to 'any assault upon any peace officer or revenue officer in the due execution of his duty, or upon any person acting in aid of such officer; of any assault upon any person with intent to resist or prevent the lawful apprehension or detainer of the party so assaulting...'. Section 31 was the same.

${ }^{846}$ Section 38 provided that 'Whosoever... shall assault, resist, or wilfully obstruct any peace officer in the due execution of his duty, or any person acting in aid of such officer, or shall assault any person with intent to resist or prevent the lawful apprehension or detainer of himself or of any other person for any offence' was guilty of a misdemeanour with punishment of up to 2 years imprisonment.' See also Prevention of Crimes Act 1871, s 12 and Prevention of Crimes Amendment Act 1871, s 12. See also Russell, n 38, vol 1, p 687. 
This latter section is now to be found in the Police Act 1996, s 89(1). It provides it is an offence in the case of:

Any person who assaults a constable in the execution of his duty, ${ }^{847}$ or a person assisting a constable in the execution of his duty... ${ }^{848}$

As to this offence, Archbold indicates that:

- The law on assault and battery is the same vis-à-vis a police officer (who will also include prison officers) ${ }^{849}$

- Knowledge that the person assaulted is a police officer is not necessary to sustain the charge, ${ }^{850}$

- It is not necessary to prove that the accused knew the officer was acting in the execution of his duty. ${ }^{851}$

The Law Commission (in 1992) argued for the retention of this offence. ${ }^{852}$ One would agree.

Given that this offence was once a common law offence and no different to the general common law on assault and battery (save in respect of showing that the constable was acting in the execution of his duty) it is asserted this offence should now be no different to that of assault and battery in general - save as to the punishment.

\section{Bodily Harm Offences}

Anglo-Saxon law imposed a higher penalty where the injury was sufficient to impair the fighting ability of the victim (see 4). This also prevailed in medieval times when the common law concept of mayhem was recognised (see 7).

- It is important to note that mayhem and any lesser offence of wounding (see 7) were no different to battery in their substantive nature. It was simply a matter of an increased punishment in respect of them. Further, they all possessed the same defences;

- This point has been lost sight of in the more modern incarnations of these offences which have been rendered muddled by virtue of the language employed in the OPA 1861.

\section{(a) Assault Occasioning Actual Bodily Harm ('ABH')}

The OPA, s 47 provides for imprisonment (for no more than 5 years) where a person is convicted on indictment of:

any assault occasioning actual bodily harm... ${ }^{853}$

The word 'assault' is not technically accurate since what is referred to here is a battery, bodily harm resulting. ${ }^{854}$ As to meaning of 'assault' in this section, Archbold refers to the law on common assault. Archbold also notes that the mens rea for this offence is the same as that for common assault. The only additional pre-requisite is that the assault, in fact, occasioned $\mathrm{ABH} .{ }^{85}$ As to the latter, Archbold notes the following:

\footnotetext{
${ }^{847}$ As to execution of his duty, see Archbold, n 39, para 19-328-334.

${ }^{848}$ The punishment is imprisonment not exceeding 6 months or a fine not exceeding level 5 on the scale or both. It is a separate offence for a person to resist or willfully obstruct a constable in the execution of his duty, see s 89(2).

${ }^{849}$ Archbold, $\mathrm{n} 39$, para 19-327 'Prison officers, while acting as such, have by virtue of their appointment all the powers, authorities, protection and privileges of a constable. Prison Act 1952, s 8 . Section 8 does not apply to prisoner custody officers employed at contracted out prisons: CJA 1991, s 87(2).'

${ }^{850}$ Archbold, $\mathrm{n}$ 39, para 19-335 'Knowledge that the person assaulted was a police officer is not necessary to sustain a charge.' Archbold cited $R v$ Forbes \& Webb (1865) 10 Cox 362, Rv Maxwell \& Clanchy (1909) 2 Cr App R 26 and McBride v Turnock [1964] Crim LR 456.'

${ }^{851}$ Ibid. Mistaken belief, and mistake as to the powers of the officer, are also discussed.

${ }^{852}$ See n 635, p 43.

${ }^{853}$ See also Archbold, n 39, para 19-242. Greaves, n 818, p 76 'The first part of this clause is taken from the 14 \& 15 Vict c 100 s 29 [1851]...Upon a count for an assault occasioning actual bodily harm, the jury may convict of a common assault, Reg $v$ Yeadon, 1 Leigh \& C 81 .' For the latter see 169 ER 1312.

${ }^{854}$ Archbold, n 39, para 19-247. Archbold also states: 'It must be proved that the assault (which includes 'battery') 'occasioned' or caused the bodily harm. Where the harm is not the direct result of the defendant's act, as, for example, where his conduct was such as to provoke the victim to jump from a moving car, the test is whether the victim's act was the natural result of the defendant's action or words, in the sense that it was something that could reasonably have been foreseen as the consequence of what he was saying or doing.' Archbold cites $R v$ Roberts (1971) 56 Cr App R 95 (girl jumped from car asserting she had been assaulted and threatened).

${ }^{855}$ Archbold cites Roberts (see $\mathrm{n}$ above),Venna (see 30) and Savage (see 32).
} 
- 'Bodily harm' has its ordinary meaning and includes any hurt (or injury) calculated to interfere with the health or comfort of the victim. Such hurt (or injury) need not be permanent, but must be more than merely transient or trifling, ${ }^{856}$

- $\mathrm{ABH}$ is capable of including psychiatric injury but not mere emotions - such as fear, distress or panic or psychological injury. ${ }^{857}$

ABH is simply a more severe battery save that - unlike battery - it can include psychiatric injury.

- In fact, the words 'actual bodily harm' do not add much since all batteries must involve some degree of bodily injury;

- $\mathrm{ABH}$, therefore, simply reflects (as did Bracton's categories, see 7) a more severe injury, above and beyond common assault - one which results in a more severe sentence.

Given this, it is asserted that this crime is not needed. Instead, it should be combined with GBH (see below) to comprise a legislative offence of 'Serious Bodily Harm' (see (c) below).

\section{(b) Wounding causing Grievous Bodily Harm ('GBH')}

The OPA 1861, s 18 provides that it is an offence where a person:

shall unlawfully and maliciously by any means whatsoever wound or cause any [GBH] to any person... with intent...to do some...[GBH] to any person ... ${ }^{858}$ [Life]

The OPA 1861, s 20 provides that it is an offence where a person:

shall unlawfully and maliciously wound or inflict any [GBH] upon any other person, either with or without any weapon or instrument..., ${ }^{859}$ [5 years]

Archbold notes that s 18 creates 3 offences (wounding, causing GBH and shooting (the latter no longer so)) any of which can be committed with any of the intents specified, which might be laid in the alternative. ${ }^{860}$ As to sections 18 and 20, they are the successors (original) to mayhem and - when they were formulated in the OPA 1861 - they were intended to reflect offences developed by legislation from earlier times. However, in so doing they have become confused, ${ }^{861}$ retaining meaningless distinctions in some cases. ${ }^{862}$ Further, there is much

${ }^{856}$ Archbold, n 39, para 19-299 cites Donovan (n 541) which was cited with approval by Lords Templeman and Jauncey in Brown (see n 631), at pp $230 \& 242$. Archbold also notes that 'It may include the cutting off of a substantial part of a person's hair: DPP v Smith [2006] 2 Cr App $\mathrm{R}$; or a momentary loss of consciousness; where there is injurious impairment to the victim's sensory functions 'it is axiomatic that the bodily harm was actual' $R(T) v D P P$ [2003] Crim LR 622 (Maurice Kay J).

${ }^{857}$ Archbold cited $R v$ Chan-Fook (1993) 99 Cr App R 147, Ireland (see 32) and $R v$ Dhaliwal [2006] 2 Cr App R 24. Archbold also states: 'In the case of 'non-physical assault' ('stalking'), if the prosecution rely on symptoms described by the victim (fright/anxiety/physical aches and pains) as evidence of bodily harm, there should be expert evidence to prove that the symptoms other than pain amounted to psychological illness or injury and the pains experienced were the result of the conduct complained of: $R v$ Morris (Clarence Barrington) [1998] $1 \mathrm{Cr}$ App $\mathrm{R}$ 386.'

${ }^{858}$ In Brown (see n 631) Lord Templeman stated, p 231 'Grievous bodily harm' means simply bodily harm that is really serious and it has been said that it is undesirable to attempt a further definition.' He referred to DPP v Smith [1961] AC 290, see per Viscount Kilmuir LC, at p 335. Greaves, $\mathrm{n} 818$, p 52 'This clause is taken from the 7 Will 4 \& 1 Vict c 85, s 4 [1837].'

${ }^{859}$ See also Brown (see n 631), per Lord Templeman, at p 231 'To constitute a wound for the purposes of [s 20 of the 1861 Act] the whole skin must be broken and not merely the outer layer called the epidermis or the cuticles. See JJC (A Minor) $v$ Eisenhower [1983] 3 AE 230.' See also $R v$ Wood (1830) 1 Mood 278 (168 ER 1271). Greaves, $\mathrm{n} 817, \mathrm{p} 53$ 'This clause is taken from the 14 \& 15 Vict c 19, $\mathrm{s} 4$; [1851] and see the 10 Geo 4, c 34, s 29(1).' [see 1829]

${ }^{860}$ Archbold, n 39 para 19-253. Archbold cites $R v$ Naismith [1961] 2 AE 735.

${ }^{861}$ Thus, Archbold, n 39, para 255, states 'On a charge of wounding with intent, 'unlawful wounding' contrary to section 20 and assault occasioning $[\mathrm{ABH}]$ contrary to section 47 of the 1861 Act are alternatives, as will be the section 47 offence on a charge of unlawful wounding contrary to section 20: see $R v$ Savage [see 32]. Common assault will be a further alternative wherever assault occasioning [ABH] is an alternative: see section 6(3A) of the CLA 1967.' Also, 'On a charge of causing [GBH] with intent, contrary to section 18, verdicts of wounding or inflicting $[\mathrm{GBH}]$, contrary to section 20 , or of assault occasioning $[\mathrm{ABH}]$, contrary to section 47 (or common assault), are available alternatives: see $R v$ Mandair [1995] 1 AC 208 (in which it was held that where a jury returned a verdict of 'causing [GBH] contrary to section 20 ' of the 1861 Act as an alternative to a count alleging an offence contrary to s 18 , it had not convicted him of an offence unknown to law; the causing of the [GBH] was contrary to s 20 in that it had consisted of inflicting [GBH] upon another person). On a charge of an offence of wounding or inflicting [GBH], contrary to section 20, a verdict of assault occasioning [ABH] (or common assault) is an available alternative: $R$ $v$ Wilson, R v Jenkins [1984] AC 242. In L v Lahaye [2006] 1 Cr App R 11, the Court of Appeal suggested that good practice should dictate that where there is an allegation of an offence contrary to section 18, a count under section 20 should routinely be included in the indictment from the outset. Where the interior intent may be in issue (even though not the primary issue), such a course has obvious practical advantage; but it is submitted that there should be no such universal rule. What good practice dictates will ultimately depend on the facts of the particular case, and there are many cases where the inclusion of a count under section 20 will serve only to distract the attention of the jury.'

${ }^{862}$ See $n 840$ 
surplusage in the statement of these offences - surplusage beloved of the Victorian era. For example,

- Unlawful \& Malicious. The reference in ss 18 and 20 to 'unlawful' wounding should not require an additional element of 'malicious', since the same is not required in battery and this is just an aggravated offence. ${ }^{863}$ Thus, if a person intentionally or recklessly wounds (or, indeed, kills) another, this should be sufficient without the need to prove 'malice' as such. ${ }^{864}$ Barnes (2005) indicates this; ${ }^{865}$

- Unlawful. The reference to 'unlawful' simply excludes the same defences as are found in assault and battery; ${ }^{866}$

- Wound or Cause/Inflict. Section 18 refers to 'wound or cause' any GBH whereas s 20 refers to 'wound or inflict' GBH. In fact, both should be the same and the House of Lords endorsed that in Ireland (see 31). ${ }^{867}$ Further, there would seem no reason for reference to the word 'wound' since it is covered in any case in the concept of causing, or inflicting, GBH. A wound is simply an example of GBH - which could be equally caused by the lack of a wound. For example, by severe internal injuries caused by blows, as reflected in s 20 which refers to 'without any weapon or instrument';

- Intentionally or Recklessly. Both ss 18 and 20 fail to mention 'reckless' behaviour (likely because Kenny (in 1904, see 27) seems to have been the first to argue for this in the case of battery). However, being aggravated forms of battery, these sections should.

If the surplusage in ss 18 and 20 is removed, it becomes apparent how similar sections 18 and 20 are; and that they overlap. Thus:

s 18 'unlawfully and maliciously... wound or cause $[\mathrm{GBH}]$... with intent';

s 20 'unlawfully and maliciously... wound or inflict [GBH].'

Finally, the word 'grievous' is a synonym for 'severe' or 'serious' ${ }^{868}$ Thus, one would suggest, in modern parlance, this offence should be termed 'Serious Bodily Harm'. As to its nature, Archbold states:

[GBH] should be given its ordinary and natural meaning of really serious bodily harm, and it is undesirable to attempt any further definition of it... It is not necessary that it should be either permanent or dangerous. Nor is it a precondition that the victim should require treatment or that the harm have lasting consequences, in assessing whether particular harm was 'grievous', account had to be taken of the effect on, and circumstances of, the particular victim... Bodily harm includes psychiatric injury but not psychological injury. ${ }^{869}$

This statement is no different to that in respect of ABH. Thus, the two (ABH and GBH) should be conflated into one, in the case of any new legislative formulation.

\footnotetext{
${ }^{863}$ Archbold, n 39, para 19-262. 'In $R v$ Mowatt [1968] 1 QB 421 Diplock LJ observed that on a charge contrary to section 18, 'maliciously' adds nothing, because the ulterior intent required by the section is more specific than such element of foresight of consequences as is implicit in the word 'maliciously'. This will be the case where the allegation is causing $[\mathrm{GBH}]$ with intent to do $[\mathrm{GBH}]$. Where the charge is wounding with intent to do $[\mathrm{GBH}]$, it is at least theoretically possible that the $\mathrm{D}$ intended to do $[\mathrm{GBH}]$ but did not intend to wound. In such a case the word 'maliciously' would theoretically come into play, but since 'malicious wounding' requires proof only of foresight of some physical harm, the point is likely to remain theoretical only. Anyone who intends to do $[\mathrm{GBH}]$ may safely be taken to foresee some physical harm resulting from his actions. It is respectfully submitted therefore, that, in these two cases, judges, directing juries, can safely ignore the word 'maliciously' as was suggested in Mowatt.'

${ }^{864}$ As Glanville Williams pointed out, $\mathrm{n} 47, \mathrm{p} 332$ “'Malice' has become settled to mean intention or recklessness.' Also, 'Wilfulness' is merely a synonym for intention.' See also, pp 72-6. At p 76 'It may be suggested that in any future codification the terms 'intentionally or recklessly' should be used in place of 'maliciously', and that 'wilfully' should either be abandoned or defined to mean 'intentionally.'

${ }^{865}$ [2005] 1 Cr App R 30. See also Archbold, n 39, para 19-262.

${ }^{866}$ Archbold, n 39, para 19-261 'The requirement in both sections that the wounding or [GBH] be unlawful imports no more than that self-defence, defence of others, defence of property, force used for the prevention of crime... are all potential 'defences'.' See also Brown (see n 631), per Lord Templeman, p 231 'In section 20 the words 'unlawfully' means that the accused had no lawful excuse such as self-defence. The word 'maliciously' means no more than intentionally for present purposes.' Lord Templeman referred to Mowatt (see n 863).

${ }^{867}$ Archbold, n 39, para 19-260 'It was formerly accepted that 'causing' was wider than 'inflicting' and that where the allegation was of causing $[\mathrm{GBH}]$, the issue was a straightforward one of causation. Did the injury result from the act of the accused? There is no requirement of physical contact between the $\mathrm{D}$ and the victim. The distinction has, however, been reduced to vanishing point by the decision of the House of Lords in $R$ $v$ Ireland [see 32] ... to the effect that [GBH] could have been 'inflicted' without an assault and without the direct or indirect application of force to the victim's person (psychiatric injury caused by persistent harassment).'

868 'Serious' bodily harm was proposed by the Law Commission in 1992, see n 635, p 23. See also p 32 (no attempt should be made to define 'serious' injury). See also Metheram (1961) 45 Cr App R 304 and OED, n 245 (grievous).

${ }^{869}$ Archbold, n 39, para 19-258.
} 


\section{(c) Conclusion - ABH \& GBH}

In Bracton's time (see 7), there was battery (wounding) as well certain aggravated offences (mayhem, GBH and $\mathrm{ABH}$ ), depending on the seriousness of the injury. However, the latter were no different to battery - save as to the imposition of a more severe punishment.

- Unfortunately, the OPA 1861 cobbled together older legislative provisions on mayhem, GBH and ABH and the result has become something of a 'dog's dinner', with endless cases, early history forgotten and courts and people struggling with prolix (and confused) Victorian drafting;

- It is asserted that this can (and should) be easily remedied, by modern legislation providing for 'Serious Bodily Harm' (SBH) - an offence which combines GBH and ABH and which is no different to battery, save as to the more severe punishment.

It is asserted that ABH and GBH should become a new offence of 'Serious Bodily Harm'- one which has the same actus reus and mens rea (and defences) as for battery ${ }^{870}$ and the only difference being a more severe punishment. This would be to return the law to the harmony which it one had, as well as its simplicity. For wording, see Appendix $\mathrm{H}$.

\section{Miscellaneous Aggravated Offences- Choking Etc.}

Archbold mentions various miscellaneous offences connected to battery and contained in the OPA 1861 . Excluding the reference to the punishment (which is noted in brackets at the end), the prolix wording of these sections are as follows:

\section{- Attempting to Choke ${ }^{871}$ 'Whosoever shall:}

- by any means whatsoever, attempt to choke, suffocate, or strangle any other person, or

- by any means calculated to choke, suffocate, or strangle, attempt to render any other person insensible, unconscious, or incapable of resistance,

with intent in any of such cases thereby to enable himself or any other person to commit, or with intent in any of such cases thereby to assist any other person in committing any indictable offence...' (wording divided for ease of reference) [s 21 - Life]

- Administering Chloroform ${ }^{872}$ Whosoever shall unlawfully apply or administer to, or cause to be taken by, or attempt to apply or administer to, or attempt to cause to be administered to or taken by, any person, any chloroform, laudanum, or other stupefying or overpowering drug, matter or thing, with intent in any of such causes thereby to enable himself or any other person to commit, or with intent in any of such cases thereby to assist any other person in committing, any indictable offence...' [ s 22 Life]

- $\quad$ Administering Poison ${ }^{873}$ This comprises two offences:

- Whosoever shall unlawfully and maliciously administer to, or cause to be administered to or taken by any other person any poison, or other destructive or noxious thing, so as thereby to endanger the life of such person, or so as thereby to inflict upon such person any grievous bodily harm...[s $23-10$ years]

- Whosoever shall unlawfully and maliciously administer to, or cause to be administered to or taken by any other person, any poison or other destructive or noxious thing, with intent to injure, aggrieve, or annoy such person...' [s $24-5$ years].

In 1992, the Law Commission considered that sections 21-3 should be repealed, being examples of serious injury. ${ }^{874}$ One would agree.

\footnotetext{
${ }^{870}$ As to lawful correction, this should only be lawful when it excludes homicide, serious violent assault, violent assault and threatened violent assault.

${ }^{871}$ See Archbold, n 39, para 19-270. Greaves, n 817, p 54 'This clause is new, and is directed against those attempts at robbery which have been accompanied by violence to the throat.'

${ }^{872}$ Ibid, para 274. Greaves, n 817, p 54 'This clause is taken from the 14 \& 15 Vict c 19, s 3.' [1851]

${ }^{873}$ Ibid, para 278. Greaves, n 817, p 55 (re s 23) 'This clause is taken from the 23 \& 24 Vict c 8, s 1.' [1860] And (re s 24) 'This clause is taken from the 23 \& 24 Vict c 8 s 2' [1860]. See also $R v$ Wilkins (1861) 1 Leigh \& Co 89 (169 ER 1316)(put cantharides into a woman's tea to excite sexual passion, she became very ill.) and $R v$ Hill (1986) 83 Cr App R 386 (administering tablets for sexual purposes). See also Carter, $\mathrm{n} 749$, pp $102-7$.

${ }^{874}$ See, n 635, pp $46 \& 115$.
} 
In conclusion, these offences should be repealed save for section 24 - the wording of which should be modernised.

\section{Miscellaneous Offences - Explosives}

The OPA 1861 contains various batteries relating to explosives, viz.

- Causing bodily injury by explosives ${ }^{875}$ Whosoever shall unlawfully and maliciously, by the explosion of gunpowder or other explosive substance, burn, maim, disfigure, disable, or do any [GBH] to any person .... ${ }^{876}$ [s 28 - Life]

- Using Explosives 'Whosoever shall unlawfully and maliciously cause any gunpowder or other explosive substance to explode, or send or deliver to, or cause to be taken or received by any person, any explosive substance or any other dangerous or noxious thing, or put or lay at any place, or cast or throw at or upon or otherwise apply to any person, any corrosive fluid or any destructive or explosive substance, with intent in any of the cases aforesaid to burn, main disfigure, or disable any person, or to do some [GBH] to any person shall, whether any bodily injury be effected or not ..., ${ }^{877}[\mathrm{~s} 29$, Life](wording underlined does not relate to battery)

The Law Commission (in 1992) considered that section 28 should be repealed; and that the other sections be considered in light of a review of Explosive Substances Act $1883 .{ }^{878}$ One would agree, save that the non-underlined wording in section 29 should also be repealed, since it relates to causing GBH (or an attempt to do so). As to the other offences in the OPA 1861 in respect of explosives (i.e. ss 30 and 64), it is asserted that they should be placed in the Explosives Act 1883 (as well being modernised).

In conclusion, $s 28$ and the majority of section 29 should be repealed. The remainder should be placed in the Explosives Act 1883.

\section{Miscellaneous Offences - Spring Guns \& Railways}

The OPA 1861 contains various batteries relating to spring guns, railways and furious driving, viz.

- Setting Spring Guns 'Whosoever shall set or place, or cause to be set or placed, any spring-gun, man trap, or other engine calculated to destroy human life or inflict [GBH], with intent that the same or whereby the same may destroy or inflict [GBH] upon a trespasser or other person coming in contact therewith ... ${ }^{879}$ [s $31-5$ years $]$

Although this section applies to instruments designed to cause GBH to humans, it does not punish the same as such. $^{880}$

\footnotetext{
${ }^{875}$ See also s 30. It provides: 'Whosoever shall unlawfully and maliciously place or throw in, into, upon, against, or near any building, ship, or vessel any gunpowder or other explosive substance, with intent to do any bodily injury to any person, shall, whether or not any explosion take place, and whether or not any bodily injury be effected, be guilty of felony, and being convicted thereof shall be liable, at the discretion of the court, to be kept in penal servitude for any term not exceeding fourteen years . . or to be imprisoned. ' See also Archbold, n 39, para 19-289.

${ }^{876}$ Greaves, $\mathrm{n} 818$, p 57 'This clause is taken from the 9 \& 10 Vict c 25, s 3.' [1846]. See also s 64 (making gunpowder to commit offences against the Act). 'Whosoever shall knowingly have in his possession, or make or manufacture, any gunpowder, explosive substance or any dangerous or noxious thing, or any machine, engine, instrument or thing, with intent by means thereof to commit, or for the purpose of enabling any other person to commit, any of the felonies in this Act mentioned shall be guilty of a misdemneanor and being convicted thereof shall be liable at the discretion of the court, to be imprisoned for any term not exceeding two years.' See also Archbold, n 39, para 19-290.

${ }^{877}$ See also Archbold, para 19-288. G reaves, n 817, p 58 'This clause is taken from the 9 \& 10 Vict c 25 s 4 [1846] and 7 W4 \& 1 Vict c 85 , s 5 [1837]. Under those Acts, if a person had placed an infernal machine in any place where he believed another would tread on it, and thereby cause it to explode, he would not have been guilty of an offence. The words 'put or lay at any place', were introduced to meet all such cases.' ${ }^{878}$ Also, the LC, n 536, pp 118-120.

${ }^{879}$ Archbold, para 19-297, referring to s 31, which wording continues 'and whosever shall knowingly and wilfully permit any such spring-gun, man trap, or other engine which may have been set or placed in any place then being in or afterwards coming into his possession or occupation by some other person to continue so set or placed, shall be deemed to have set or placed such gun, trap, or engine with intent as aforesaid: provided that nothing in this section contained shall extend to make it illegal to set any gin or trap such as may have been or may be usually set or placed with the intent of destroying vermin; provided also, that nothing in this section shall be deemed to make it unlawful to set or place, or cause to be set or placed, or to be continued set or placed, from sunset to sunrise, any spring gun, man trap, or other engine which shall be set or placed, or caused or continued to be set or placed in a dwelling house for the protection thereof.' This wording does not contain any offence as such and one would suggest that the wording in italics is not appropriate today. Greaves, n 817, p 31 'This clause is framed from the $7 \& 8$ Geo 4 c 18 [1827] with some slight verbal alterations.'

${ }^{880}$ Ibid, para 19-299 'This statute applies only to instruments set with an intention to do [GBH] thereby to human beings, or whereby [GBH] may be done to a human being.' For the placing of spring guns to stop poachers in early Victorian times see Memoirs of the Life of Sir Samuel Romilly (John Murray, 1840), vol 2, pp 283-4 (re position in 1817).
} 
- The Law Commission (in 1992) considered that this section should be reviewed. One would agree not least since such 'spring guns' were rudimentary burglar alarms in Victorian times (and prior to that), as well as being designed to catch poachers;

- Today, with modern burglar alarms (as well as better locks on doors, double glazing etc.), it is asserted that no provision need be made on this.

This, if a person does place a 'spring gun' (burglar alarm, when in a house) of whatever nature and a person is injured (whether a trespasser) then general law should apply. If the same was placed intentionally (or recklessly) to kill or cause a Violent Assault (including where serious bodily harm arises), then it should be a criminal offence. If negligently placed, a civil action will lie.

- Endangering Rail Passengers 'Whosoever shall unlawfully and maliciously put or throw upon or across any railway, any wood, stone, or other matter or thing, or shall unlawfully and maliciously take up, remove, or displace any rail, sleeper, or other matter or thing belonging to any railway, or shall maliciously turn, move, or divert any points or other machinery belonging to any railway, or shall unlawfully and maliciously make or show, hide or remove, any signal or light upon or near to any railway, or shall unlawfully or maliciously do or cause to be done any matter or thing, with intent, in any of the cases aforesaid, to endanger the safety of any person travelling or being upon such railway... ${ }^{881}$ [s 32 -Life]

Also, 'whosoever shall unlawfully and maliciously throw, or cause to fall or strike at, against, into, or upon any engine, tender, carriage, or truck used upon any railway, any wood, stone, or other matter or thing, with intent to endanger the safety of any person being in or upon such engine, tender, carriage or truck, or in or upon any other engine, tender, carriage, or truck of the train of which such first mentioned engine, tender, carriage, or truck shall form part ... ${ }^{882}$ [s 33 - Life]

Also, 'Whosoever, by any unlawful act or by any wilful omission or neglect, shall endanger or cause to be endangered the safety of any person conveyed or being in or upon a railway, or shall aid or assist therein. ${ }^{.83}$ [s 34 - 2 years]

It is asserted that the underlined wording to should now refer to 'intentionally or recklessly', for there to be a criminal offence. The Law Commission (in 1992) considered that the above should be reviewed, modernised and simplified. ${ }^{884}$ One would agree. Also, that it should be contained in legislation dealing with railways.

- $\quad$ Furious Driving 'Whosoever having the charge of any carriage or vehicle, shall, by wanton or furious driving or racing, or other wilful misconduct, or by wilful neglect, do or cause to be done any bodily harm to any person whatsoever. ${ }^{885}$ [s $35-2$ years]

The Law Commission considered that this section should be repealed. One would agree. ${ }^{886}$

In conclusion, the wording of these offences should be modernised. It should also be dovetailed with a legislative form of assault and battery.

\section{Racially \& Religiously Aggravated Offences}

The Crime and Disorder Act 1998, s 29 provides for a greater punishment in the case of racially - or religiously aggravated offences in respect of the OPA 1861, ss $20(\mathrm{GBH})$ and $47(\mathrm{ABH})$ as well as common assault. This should be reflected in any new legislative offences in respect of the same.

\section{Conclusion}

The Law Commission (in 1992) noted that:

\footnotetext{
${ }^{881}$ Ibid, para 19-300. Greaves, n 818, p 60 'This clause is taken from the 14 \& 15 Vict c 19 s 6, [1851] and the word 'unlawfully' is substituted for 'wilfully' throughout.'

${ }^{882}$ See Archbold, n 39, para 19-300. Greaves, n 818, p 61 'This clause is taken from the 14 \& 15 Vict c 19 s 7.' [1851]

${ }^{883}$ Ibid, para 19-300. Greaves, $\mathrm{n} 817$, p 62 'This clause is taken from the 3 \& 4 Vict c 97, s 15.' [1840]

${ }^{884}$ See LC, n 536, pp 121-2.

${ }^{885}$ Ibid, para 19-305. Archbold comments 'The offence contrary to section 35 is used today to deal with horse-drawn carriages and vehicles, and with motorists and cyclists who cannot be prosecuted for dangerous driving or cycling because their conduct did not take place on a road or (in the case of motorists) on a public place, or because they were not given a warning of intended prosecution (see sect 1 of the RTOA 1988).' Greaves, $\mathrm{n} 817, \mathrm{p}$ 63. 'This clause is taken from the $1 \mathrm{Geo} 4, \mathrm{c} 4$ [1820] which was confined to stage coaches and public carriages, and to the wanton and furious driving or racing, or wilful misconduct of coachmen and others having the charge of such coaches and carriages. The present section includes all carriages and vehicles, and extends also to wilful neglect.'

${ }^{886}$ LC, n 536, p 122.
} 
The clarification and rationalisation of the criminal law is an important objective, not least because of the burden that an obscure and unnecessarily complicated law places on the courts. Some parts of the criminal law will always, necessarily, be difficult; but a law that even the judges find hard to administer threatens not merely waste of time and excessive cost, but also positive injustice. ${ }^{887}$

The law on assault and battery as well as on aggravated assaults, was (and should be) very simple. However, today, it is weighed down by a vast number of old legal texts and definitions which are no longer of any worth. Further, the common law and the legislation on aggravated offences are out of sync, not least because of ponderous Victorian wording in the case of the latter. The position may be stated succinctly:

\section{(a) Assault \& Battery}

- Assault \& Battery. The offences of assault and battery should now be placed in legislation. They should remain separate offences. Their descriptions should be modernised. They should now be termed 'Violent Assault' and 'Threatened Violent Assault'; ${ }^{888}$

- Obsolete Offences. Offences concerning: (a) assaults in court (including rescuing prisoners); (b) assaulting clergymen; and (c) assaults in respect of wreck, are obsolete and are no longer required. Nor is the OPA 1861, s 38 (re assaulting a person with intent to resist (or prevent) the lawful apprehension or detainer of himself or of any other person);

- Assaulting a Prison Officer. Assaulting a police officer (and a prison officer) in the execution of his duty should be no different to the general offences of assault and battery, save as to the punishment, which should be more severe;

- Defences. The defences to assault and battery derived from homicide and mayhem. They should all now be in legislative form and should apply to homicide, assault, battery and aggravated assault. Thus, the CIJA 2008, s 67 should cover (a) self-defence; (b) defence of others; (c) defence of land and possessions; (d) reasonable infliction of battery pursuant to due legal process;

- Correction of Children, Games, Surgerv. Since these are not 'defences' as such (no crime is committed where there is no intent to cause a breach of the peace or the assault or battery is minor), legislation should set out the legal position, in order to remove present uncertainty and help the general public who should not be placed 'in terrorem' of litigation.

\section{(b) Aggravated Offences}

- Serious Bodily Harm. ABH and GBH should be merged to comprise a new offence of 'Serious Bodily Harm' ('SBH') which is no different to battery - save as to the punishment (and that it can be committed psychiatrically);

- Specialised Aggravated Offences - Explosives, Railwavs. Miscellaneous OPA 1861 offences such as attempting to choke, administering chloroform, poison, etc. should be repealed - save where otherwise noted (e.g. section 24 re poison). Further, where they relate to explosives (see part of s 29 and ss 30 and 64) or railways (ss 32-4) - being very specific - they should be placed in the Explosives Act 1883 and railways legislation.

Would any of the above be controversial?

- As to obsolete material this reflects the views of the Law Commission in 1992 and there has been no caselaw or other matters since to suggest that their proposal is unsatisfactory;

- As to assault and battery, there now seems to be a high degree of concurrence as to their mens rea and actus reus (both as a crime and a tort);

- As to the need to replace the OPA 1861, this was also proposed by the Law Commission and it is eminently sensible. Also, placing specialist offences (re explosives and railways) in their specific legislation - something they also proposed.

\footnotetext{
${ }^{887}$ Ibid, p 2. See also Henry LJ in Lynsey (see n 453, a case concerning a possible discrepancy between the OPA 1861, s 39 and s 40 re the inclusion of battery), at p 655, he observed that this was 'yet another example of how bad laws cost money and clog up the courts with better things to do. In so saying, we are critical of the existing state of the law but make no criticism of the judge and the practitioners in this case who had to operate within the legal system as they found it.' And as to the discrepancy, at p 657 'At this point angels prepare to dance on needles and legal pedants sharpen their quill pens.'

${ }^{888} \mathrm{Ibid}, \mathrm{p} 11$ 'It is of the essence ...that the criminal law should employ a consistent vocabulary and that the meanings of key terms should be as clear as possible. That would correct a notable weakness in the English criminal law.'
} 
In conclusion, this area of law can, and definitely should be, simplified - in order to prevent the courts having to trawl through old caselaw or (in some cases) forgetting it. 


\section{APPENDIX A: TARIFF OF WOUNDS}

Below is listed the tariff for wounds in the times of king Aethelbert (c. 558-616), king Alfred (871-99) and in the Laws of Henry I (c.1113). The sums are listed in shillings, sceattas (where stated) and pence (where stated).

\section{$\underline{\text { Aethelbehrt }}^{889} \quad \underline{\text { Alfred }} \quad \underline{\text { Henry I }}$}

(a) $\underline{\text { Hair }}$

Seizing by the hair

50 sceattas $^{890} \quad$ wound under hair - 1 (in front, 2) $\quad$ 1(in front, 2)

(b) Bones

Bone - laid bare

Bone - damaged

$3^{891}$

$4^{892}$

(c) $\underline{\text { Head }}$

Skull - outer covering

10

$15^{893}$

15

Bone and skull

20

$30^{894}$

30

Neck

100 (tendons damaged severely) $^{895}$

100 or more

\section{(d) Shoulder}

Shoulder disabled

(e) Hearing \& Ears

Hearing destroyed

Ear struck off

Ear pierced

Ear lacerated

\section{(f) Eye \& Mouth}

Eye knocked out Mouth or eye disfigured

\section{(g) Nose \& Cheeks}

Nose pierced

Cheek pierced

9

3

6

Both cheeks pierced

Nose otherwise lacerated

6 (if pierced, 6) 60 (if nose struck off)

\section{(h) Chin \& Teeth}

Chin bone smashed

Teeth

6

$66 \& 6 p$
60

30

60

30

$66 \& 6 p^{898}$

\footnotetext{
${ }^{889}$ See Attenborough, n 6, pp 9-15.

${ }^{890}$ Wormald, n 71. Attenborough, n 6, p 176 'The sceatt was the predecessor of the penny and was apparently intended to be of the same standard (21 grs)...'

${ }^{891}$ All references are to shillings unless otherwise stated.

892 If outer bone (skull) is pierced, 15 .

${ }^{893}$ If outer bone (skull) is pierced, 15.

${ }^{894}$ If wound to head, if both bones pierced.

${ }^{895}$ Attenborough, n 6, p 93.

${ }^{896} \mathrm{Ibid}, \mathrm{p} 89$ 'If a man is wounded in the shoulder, so that the synovia [synovial fluid, fluid in the joints] flows out, 30 shillings shall be paid as compensation.' Cf. $\mathrm{p} 91$ 'If a man is wounded in the shoulder, 80 shillings shall be paid as compensation, if he can be cured.' At $\mathrm{p} 93$ 'If anyone smashes another's shoulder, 20 shillings shall be given to him as compensation.'At p 93 'If anyone hacks into it [shoulder], and a bone is removed, 15 shillings shall be given as compensation for it [in addition to the above].'

${ }^{897}$ If the shoulder is maimed, it is 20 shillings.

${ }^{898}$ If the eye remains in the head 'but so that the man can see nothing with it, a third part of the compensation otherwise payable shall be withheld.' Downer, n 8, p 295.

${ }^{899}$ The text notes that 'Men have more teeth, women have less.' It also distinguishes between incisors, canines and molars. See Downer, $\mathrm{n} 8$, p 295.
} 
Power of speech injured

Tongue

\section{(i) Collar Bone \& Arm}

Collar bone injured

Arm pierced

Arm broken

\section{(j) Thumb, Fingers, Nails}

Thumb, fingers, nails Slightest dis-figurement

$$
1-20
$$

3-6

12 (throat pierced)

$66 \& 6 p$ (if torn from mouth)

12 (throat)

\section{(k) $\underline{\text { Blows }}$}

Fist striking nose 3

Bruising and blows 20 sceattas -1

\section{(I) Stomach, Thigh, Ribs}

80 (if arm below elbow cut off) 30 (both bones in arm broken)

30

$5 p-30^{901}$

$\begin{array}{ll}\text { Wounding belly } & 12^{902} \\ \text { Thigh broken } & 12 \\ \text { Rib broken } & 3 \\ \text { Thigh pierced } & 1-6 \\ \text { Sinew wounded } & 3 \\ \text { Loin } & \\ \text { Shin } & \end{array}$

\section{(m) $\underline{\text { Penis }}$}

Destroys/pierces penis 6-3x wergild $^{905}$

\section{(n) Feet \& Toes}

Injury to feet/toes

10 sceattas -50

$60 \& 6 p$ (hand/foot struck off)

$5-20$ (toes)

30 (if pierced through, 20) $30(20)$

30 (if fractured) 30

10 (without breaking skin) ${ }^{903} \quad 10(15)$

30 (if pierced)

6-30

60 (maimed/pierced, 15-30)

80 (struck off at knee)

12 (shin pierced/fractured, 30)

6 (small sinew) ${ }^{904}$

$60(15-30)$

80

$12(30)$

80

(o) Medical Treatment \& Severe Wounding

Medical treatment needed $\quad 30$

Severely wounded 30

30

\section{APPENDIX B - DEFINITIONS: 1581-1965}

Below, are definitions of assault and battery taken from the principal texts on criminal law in period 1581-1965. These definitions are defective in a number of respects, including the following: (a) they fail to indicate that assault and battery can be committed (as a criminal offence) recklessly as well as intentionally; (b) they suggest that an assault requires the assailant to act in a hostile or revengeful manner, when this is unnecessary; (c) they indicate that assault is an attempted battery, when it is not. Rather, it is a threatened battery - as some of the legal writers below mentioned, note (this wording is underlined).

Lambard An assault... can not be performed without the offer of some hurtful blow, or at the least some fearful [i.e. a threatened] speech. (see 10)

Cowell $1607 \quad$ Assault. Insultus ... signifieth.... violent kind of injurie offered to a man's person...it may be committed by offering of a blowe, or by fearefull [i.e. threatening] speech... ${ }^{906}$ Battery... signifieth... a violent striking of any man. (see 11).

${ }^{900}$ The same as an injured eye.

${ }^{901}$ External injury to the hand is 20 (if 'half hand flies off', it is 60).

902 If pierced through it was 20.

${ }^{903}$ If the skin is broken and a bone removed, it is 15 . Attenborough, $\mathrm{n} 6, \mathrm{p} 91$.

${ }^{904}$ It is 12 if great sinews of lower legs are injured, and 30 if the person is made lame.

${ }^{905}$ If pierced right through, 6 , if partially, 6 .

${ }^{906}$ The 1708 edition of Cowell stated 'Assault, Insultus or Assultus...signifies in law a violent kind of injury offered to a man's person, of a higher nature than a battery, for it may be committed by offering of a blow, or by a threatening speech...To strike at a man, though he be neither hurt nor hit, hath been adjudged the like...Battery...is a violent striking or beating any man.' 
Sheppard

Termes de la Ley

Hawkins

Burn

Jacob

Finch
Assault is an attempt to execute the thing menaced by force and violence. Battery is the performing of the thing before threatened, viz. the beating of him that was first menaced, and then assaulted (see 12).

Battery is the wounding or beating another. Assault is, when one unlawfully sets upon the person of another, offering to beat him, although he beats him not, or striking at him, though he strikes him not. ${ }^{907}$ (see 13)

Assault is an unlawful setting upon one's person... Batterie is the wrongful beating of one..$^{908}$

An assault upon a man's person by another... does import the offer of any hurtful blow or fearful speech. (see 11)

Assault (which is) where one does unlawfully set upon and attempt to beat another, but does it not. Battery (which is) when one does unlawfully beat another. (see 13)

Assault ... signifies a violent kind of injury offered to a man's person, of a more large extent than battery; for it may be committed by offering a blow, or by a terrifying speech...Batterie is an act which tends to the breach of the peace of the realm; as when a man assaults and beats another. (see 11)

an assault is an attempt, or offer, with force and violence, to do a corporal hurt to another... [battery is] any injury whatsoever, be it never so small, being actually done to the person of a man, in an angry, or revengeful, or rude, or insolent manner. (see 15)

Assault (assultus) is a violent injury offered to a man's person, of a higher nature than battery, for it may be committed by offering a blow, or by a terrifying speech...Battery ...is a violent striking or beating a man. (see 11)

Assault ... is an attempt or offer, with force and violence, to do a corporal hurt to another...Battery...seems to be, when any injury whatsoever, be it never so small, is actually done to the person of a man, in an angry, or revengeful, or rude, or insolent manner. (see 17)

Assault (assultus)... Signifies a violent injury offered to a man's person, of a more extensive nature than a battery: for it may be committed by offering a blow, or by a terrifying speech... Battery... is an injury done to another in a violent manner; as by striking or beating of a man, pushing, jolting, filliping upon the nose, etc. (see 11)

Assault is when one unlawfully sets upon the person of any man; as if he offer to beat him, tho' he do not beat him in deed; if he strike at him with a hatchet, or the like, tho' he do not hit him... Battery is the wrongful beating of one (see 17)

assault; which is an attempt or offer to beat another, without touching him... battery; which is the unlawful beating of another. The least touching of another's person wilfully, or in anger, is a battery. (see 17)

an assault is an attempt or offer by force or violence, to do a corporal hurt to another ... a battery.... is the actual doing an injury, be it ever so small, in an angry, or revengeful, or rude, or insolent manner. (see 19)

An assault is any attempt or offer with force and violence to do a corporal hurt to another, whether from malice or wantonness... or with such other circumstances as denote at the time an intention, coupled with a present ability of using actual violence against his person..... Where the injury is actually inflicted, it amounts to a battery (which includes an assault) and this, however small it may be. (see 20)

An assault is an attempt to offer, with force and violence to do a corporal hurt to another ... accompanied with such circumstances as denote at the time an intention, coupled with a present ability, of using actual violence against a person of another ...A battery is more than an attempt to do a corporal hurt to another: but any injury whatsoever, be it ever so small, being actually done to the person of a man, in an angry or revengeful, or rude, or insolent manner. (see 21) 909 $^{-10}$

An assault is an attempt to commit a forcible crime against the person of another:..A battery,

\footnotetext{
${ }^{907}$ The last edition of Dalton in 1746, p 281, stated: 'Battery is the wounding or beating another. Assault is, when one unlawfully sets upon the person of another, offering to beat him, although he beats him not, or striking at him, although he strikes him not.'

${ }^{908}$ The last edition of Finch in 1759, p 202, stated: 'Assault is when one unlawfully sets upon the person of any man; as if he offer to beat him, tho'he do not beat him in deed; if he strike at him with a hatchet, or the like, tho' he do not hit him.. ...Battery is the wrongful beating of one.'

${ }^{909}$ In the last edition in 1964, Russell, n 38, ch 37, stated: 'An assault...is a threat by one man to inflict unlawful force (whether light to heavy) upon another; it constitutes a crime at common law when the threatener, by some physical act, has intentionally caused the other to believe that such force is about to be inflicted upon him...A battery consists in the actual application of unlawful force to another person...'(see 29).
} 
Gabbett in the legal acceptation of the word, includes beating and wounding. To beat... includes every touching (however trifling) of another's person, in an angry, revengeful, rude, or insolent manner. ... A wounding is where the violence is so great as to draw blood. (see 22)

any attempt or offer with force and violence to do a corporal hurt to another, whether from malice or wantonness..., , in an angry or threatening manner, is an assault... when the injury which is menaced or intended, be it never so small, is actually inflicted, it is then distinguishable as a battery, as by spitting in a man's face, or any way touching him in an angry, revengeful, rude, or insolent manner, without lawful cause, a 'battery' not being confined to a violent striking, which the term in common parlance imports, but extending even to the laying on of hands against a person's will. (see 23)

An assault consists in any attempt or offer, by a person having present ability, with force to do any hurt or violence to the person of another. A battery consists in any the least hurt or violence unlawfully and wilfully or culpably done to the person of another. ${ }^{910}$

An assault is an attempt, with force or violence, to do a corporal injury to another against his will... accompanied with such circumstances as denote at the time an intention, coupled with a present ability, of using actual violence against the person of another...A battery, which always includes an assault, is an injury inflicted on a person by beating. (see 24)

An assault is an attempt or offer to commit a forcible crime against the person of another.....A battery is not necessarily a forcible striking with the hand or stick or the like, but includes every touching or laying hold (however trifling) of another person, or his clothes, in an angry, revengeful, rude, insolent or hostile manner. (see 25)

An assault is the act of intentionally applying force to the person of another directly or indirectly, or attempting or threatening by any act or gesture to apply such force to the person of another, if the person making the attempt or threat has, or causes the other to believe upon reasonable grounds that he has, present ability to effect such purpose. ${ }^{911}$

An assault is (a) an attempt unlawfully to apply any the least actual force to the person of another directly or indirectly, (b) the act of using a gesture towards another giving him reasonable grounds to believe that the person using that gesture meant to apply such actual force to his person as aforesaid... A battery is an assault whereby any the least actual force is actually applied to the person of another, or to the dress worn by him, directly or indirectly. (see 25)

An 'assault' is an attempt, or offer, with force and violence, to a corporal hurt to another ...A battery in an injury done to the person of a man in an angry, revengeful, rude or insolent manner. In other words, an assault is a movement which attempts, or threatens, the unlawful application of force to another person; whilst such application itself, when actually effected, constitutes a battery. (see 27)

It is an assault at common law when any person intentionally, or recklessly, by active conduct threatens to apply unlawful physical force to the person of another in such a manner as to create in the mind of that other a belief that such force is about to be so applied. (see 28)

An assault is the intentional display of unlawful physical force by one person against another in such circumstances as to create in the mind of such other person the belief that such physical force is about to be used. A battery is the intentional use of unlawful physical force by one person against another. (see 28)

An assault is any act which D, intentionally or (possibly) recklessly, causes $\mathrm{P}$ to apprehend immediate and unlawful personal violence... A battery is an act by which $\mathrm{D}$, intentionally or (possibly) recklessly, inflicts unlawful personal violence upon P. (see 28)

\section{APPENDIX C - DEFINITIONS: 1969-2014}

Below, are definitions of assault and battery supplied in cases, by the Law Commission and by Archbold. It may be noted that reference is made to 'force', 'violence', 'personal violence', 'impact'. It is asserted that none of these words reflect the nature of the offence in the past, which was to punish the infliction of 'injury' on a person.

$9107^{\text {th }}$ Report of HM's Commissioners on Criminal Law (11 March 1843), Draft Code, arts 48 \& 43, see n 490 (Irish University Press), vol 4, pp 248-9. Cf. $2^{\text {nd }}$ Report of HM's for Revising and Consolidating the Criminal Law (22 ${ }^{\text {nd }}$ February, 1845), vol 5, p 213 art 43 'An assault consists in any attempt, offer, or menace by guestures, to cause any bodily harm or to do any violence to the person of another, by one who has present ability to cause such bodily harm or to do such violence.' Ibid $4^{\text {th }}$ Report for Revising and Consolidating the Criminal Law (22 ${ }^{\text {nd }}$ February, 1845), vol 5, p 518.

${ }^{911}$ See n 490. 
Fagan v MPC

1969

Venna

DDP v Morgan

Williams

Kimber

Collins v Wilcock

1984

CLRC

LC

Trindade

Wilson

Ireland

Archbold
James $J$ : An assault is any act which intentionally - or possibly recklessly - causes another person to apprehend immediate and unlawful personal violence. (see 30)

James $L J$ : We see no reason in logic or in law why a person who recklessly applies physical force to the person of another should be outside the criminal law of assault. (this actually refers to battery). (see 30 $)^{912}$

Lord Simon: 'The actus reus of assault is an act which causes another person to apprehend immediate and unlawful violence.... The foresight (the term of art is 'intention') or recklessness is the mens rea in assault.' (see 30) ${ }^{913}$

Lane CJ: Assault...is an act by which the defendant, intentionally or recklessly, applies unlawful force to the complainant. (this actually refers to battery) (see 30) ${ }^{914}$

Lawton CJ: An assault is an act by which $\mathrm{D}$ intentionally or recklessly caused the complainant to apprehend immediate, or to sustain, unlawful personal violence. (see 30) ${ }^{915}$

Robert Goff LJ: An assault is an act which causes another person to apprehend the infliction of immediate, unlawful, force on his person; a battery is the actual infliction of unlawful force on another person. (see 30) ${ }^{916}$

At common law, an assault is an act by which a person intentionally or recklessly causes another to apprehend immediate and unlawful personal violence... and a battery is an act by which a person intentionally or recklessly inflicts personal violence upon another. (see $\mathbf{3 1})^{917}$

A person would be guilty of assault if: (a) he intentionally or recklessly applies force to or causes an impact on the body of another, (i) without the consent of the other; or (ii) where the act is likely or intended to cause injury, with or without the consent of the other; or (b) he intentionally or recklessly, without the consent of the other, causes the other to believe that any such force or impact is imminent. (see 31) ${ }^{918}$

An assault is any direct threat by the defendant which places the plaintiff in reasonable apprehension of an imminent contact with the person either by the defendant or by some person or thing within the defendant's control. A battery is a direct act of the defendant which has the effect of causing contact with the body of the plaintiff without the latter's consent. ${ }^{919}$

Assault is committed where a person intentionally or recklessly causes another to apprehend an immediate and unlawful contact...battery is committed when unlawful force has been applied, intentionally or recklessly, to the body of the victim without their consent. ${ }^{920}$

battery...involves the unlawful application of force by the dependent upon the victim...assault is an act causing the victim to apprehend an imminent application of force upon her. (see $\mathbf{3 2})^{921}$

An assault is any act... by which a person intentionally - or recklessly - causes another to apprehend immediate and unlawful violence. [The act must be accompanied by a hostile intent calculated to cause apprehension in the mind of the victim. Where the hostile intent is not present, there will be no assault unless, of course, it is proved that the alleged assailant was reckless as to whether the complainant would apprehend immediate and unlawful

\footnotetext{
${ }^{912}$ This was one of the first (if not the first) judicial pronouncement to contend that battery might be committed recklessly as well as intentionally, which proposition has now been adopted.

${ }^{913}$ This actually refers to battery. In so far as it requires 'violence' it would seem incorrect, since any unlawful touching of a person is a battery - whether violent or not.

914 The word 'force' would seem too indistinct since the offence, since the $6^{\text {th }}$ century, has always comprised of the infliction of physical injury (injuria) on another - whether by wounding, beating, bruising (and, later, by merely touching).

${ }^{15}$ As to 'personal violence', see Smith \& Hogan (28(d)). 'Personal' would seem to mean in this context 'violence on the person.' An early reference to 'personal violence' is Pursell v Horne (1838) 8 A \& E 604 (112 ER 966)(threw boiling water over a person and their clothes, wetting and damaging clothes. Per Denman CJ 'I think that a battery does not necessarily mean something done cominus [that is, hand to hand]. But it must imply personal violence.'). See also Trindade, n 319, p 225.

916 'Actual (i.e. immediate) unlawful force' would seem accurate save as to the word 'force', see ns 690 and 911.

${ }^{917}$ As to 'personal violence', see n 912 (Smith \& Hogan).

918 There seems no easy means of distinguishing 'force' from an 'impact'. As to force, see ns 690 and 911.

${ }^{919}$ Trindade, n 319, pp 216, 229. Also, p 230 'Assault is the threat of force to the person of another, while battery is the actual application of force.'

${ }^{920}$ Wilson, n 50 ( $2^{\text {nd }}$ ed, 1998), pp 323, 326. Wilson also notes, p 323 'The actus reus of an assault is reducible not to fact of contact but to the threat of it.' (underlining supplied).

${ }_{921}$ As to 'force', see ns 690 and 911 .
} 
violence...] ${ }^{922}$ a battery... means an act by which a person intentionally or recklessly applies unlawful force to the complainant. (see $\mathbf{3 4})^{923}$

Notes: None of the above definitions are wholly adequate, although there is now a high degree of commonality, it being accepted that: (a) battery and assault can be intentional or reckless; (b) an act is needed (also that words alone and omission are insufficient); (c) the assault and battery must be unlawful; (d) a battery involves 'infliction'. In the case of battery, some of the above writers refer to 'violence' which is clearly incorrect. Others refer to 'force' which is too indistinct. ${ }^{924}$

It asserted the key words for a definition of battery are 'infliction' and 'on a person' (some of the above writers refer to 'personal') and that it be not just 'force' or 'impact' but must be the infliction of physical (not psychological or psychiatric) injury. Bracton excluded 'trivial injuries' from criminal sanction (see 7) and this almost certainly continued up to Cole v Turner (1705, see 14) when Holt CJ then referred to 'any touching' being a battery. This altered the law rather, with subsequent legal writers and the courts developing the idea that trivial touching (such as everyday incidents) were impliedly consented to.

\section{APPENDIX D - MODERN TORT DEFINITIONS}

Below, are definitions of assault and battery supplied in modern texts on tort. It may be noted that reference is made to 'force', 'violence', 'physical violence', 'personal violence' 'touches' and 'contact'. It is asserted that none of these words reflect the nature of battery (criminal and civil) in the past, which was to punish the infliction of 'injury' on a person. Further, the essence of assault is a threat (as various legal writers note, see underlined wording).

Clerk \& Lindsell

Cooke

Deakin
For assault, they quote Collins $v$ Wilcock. 'The direct imposition of any unwanted physical contact on another person may constitute the tort of battery. ${ }^{925}$

An assault is an act which causes another person to apprehend the infliction of immediate unlawful force on his person ${ }^{926} \mathrm{~A}$ battery is the direct and intentional application of force to another person without that person's consent.

[Assault] an act which threatens violence, or in other words, one that intentionally induces in the claimant a reasonable expectation of immediate unlawful force... battery consists of a direct act of the defendant resulting in an undesired contact with the person of the claimant. ${ }^{927}$

Assault is....an act which causes the claimant reasonably to apprehend that immediate physical violence will be used on him or her. Battery is traditionally defined as the intentional and direct application of force to another person. . ${ }^{928}$

Assault 'Where the defendant's actions cause the claimant reasonably to apprehend the direct and immediate infliction of force on him or her..[As to battery] 'Force must be applied intentionally by immediate and direct means to another individual.'

Assault is putting a person in fear of an immediate battery, and battery is the actual application of physical force, however slight, without legal justification. ${ }^{930}$

The defendant commits assault if he or she causes the claimant to fear immediate personal violence...The defendant is liable for battery if he or she inflicts force on the claimant. ${ }^{931}$

Assault (followed the definition of Collins $v$ Wilcock). A battery is the intentional application of unlawful force to another person. ${ }^{932}$

Battery occurs where there is contact with the person of another, and assault is used to cover cases where the claimant apprehends contact but is not actually touched. ${ }^{933}$

Cited Blackstone for definitions of assault and battery (see Appendix B). ${ }^{934}$

\footnotetext{
922 The wording in brackets would seem wholly incorrect. The intent need not be hostile, revengeful, angry etc.

${ }^{923}$ As to 'force', see ns 690 and 911 .

${ }^{924}$ As noted, this reference to 'force' was reflected in Victorian Indian legislation, see n 690.

${ }^{925}$ See n 723, para 15-09. 'Unlawful 'would seem more accurate than 'unwanted' (correcting a child may be unwanted (by a child), but may not be unlawful)

${ }^{926}$ Ibid, pp 423 \& 425 (quoting Collins $v$ Wilcock).

${ }^{927}$ Ibid, p 361-2.

${ }^{928}$ Ibid, pp $305 \& 307$.

${ }^{929}$ Ibid, pp $411 \& 414$

${ }^{930}$ Ibid, p 299. The reference to 'fear' is inaccurate. It is not required, see n 715.

${ }^{931}$ Ibid, pp 45-6. Re 'fear' see note above.

932 Ibid, pp 379, 383.

${ }^{933}$ Ibid, p 326.

${ }^{934}$ Ibid, pp $53 \& 57$.
} 
McBride

Murphy \& Whiting

A will commit the tort of battery in relation to B if he touches her when he has no lawful justification for doing so. A will commit the tort of assault in relation to B if he makes her think he is about to touch her when he has no lawful justification for doing so. ${ }^{935}$

An assault is any act of the defendant that directly and intentionally or negligently causes the claimant reasonably to apprehend the imminent infliction of a battery... Battery is any act of the defendant that directly or intentionally or negligently causes some physical contact with the person of the claimant without the claimant's consent. ${ }^{936}$

Assault requires no contact because its essence is conduct which leads the claimant to apprehend the application of force... The elements of battery are as follows: (1) an act; (2) by which contact is made with the claimant's body; (3) the contact must be direct; (4) the contact with the claimant's body must be hostile; and (5) the claimant did not consent to the contact. ${ }^{937}$

[Assault] The act of putting another person in reasonable fear or apprehension of an immediate battery by means of an act amounting to an attempt or threat to commit a battery amounts to an actionable assault. Intentionally to bring any material object into contact with another's person is a sufficient application of force to constitute a battery. $^{938}$

Assault requires no physical contact but is a direct threat by the defendant which intentionally places the claimant in reasonable apprehension of an imminent battery. Battery, an act of the defendant which directly and intentionally brings about contact with the body of the claimant, where the contact exceeds what is lawful. 939

\section{APPENDIX E - EXAMPLES OF ASSAULT \& BATTERY}

Comyns in his Digest (3rd ed, 1792, vol 2 usefully collected together various examples of assault and battery. These are referred to below, as well as other legal writers from Lambard (1581) until modern times.

\section{(a) Assault}

- $\quad$ Strikes at a person - but does not touch him (also cited by Lambard, Cowell, Dalton, Hawkins). ${ }^{940}$

- Lifts a weapon to strike - but does not (also cited by Buller \& Blackstone). ${ }^{941}$

- Surrounds a man's house, intending to beat him. ${ }^{942}$

- Uses menacing words in a man's presence, whereby he flees town. ${ }^{943}$

- $\quad$ Threatens to cut off a man's arm. ${ }^{944}$

- Presents a gun at someone, at a distance it will fire (also cited by Hawkins, Buller, East). ${ }^{945}$

- Points a pitchfork at someone within reach (also cited by Hawkins, Buller). ${ }^{946}$

- Lifts up a fist at another (also cited by Hawkins, Blackstone, East). ${ }^{947}$

\section{(b) $\underline{\text { Battery }}$}

- Strikes (or wounds) a person with a hand or instrument (also cited by Cowell and Pulton). ${ }^{948}$

\footnotetext{
${ }^{935}$ Ibid, p 36.

${ }^{936}$ Ibid, pp $256 \& 263$

${ }^{937}$ Ibid, pp 58 \& 64. 'Hostile' is not required. 'Consent' fails to cover the other defences.

${ }^{938}$ Ibid, pp 121-2. The references to 'fear' and 'attempt' are incorrect.

939 Ibid. p 35

${ }^{940}$ Comyns, n 26, vol 2, p 130 citing Rolle, n 21, vol 2, p 545 (referring to a case in 1348, see n 161). Cf. Comyns, p 131 'it is no assault, if a man...strike at him at such a distance that he cannot touch him, or put him in fear.'

${ }^{941}$ Comyns refers to Anon (see 14). See also Dause v Luce (see 14)(per Twisden J, holding up a sword).

${ }^{942}$ Comyns makes no reference. Under Roman law (Lex Cornelia, see n 60) and Anglo-Saxon law (hamsocn, see also n 132) it was a crime to attack a man's house. In respect of surrounding a house see also Mead (1823, see n 548). In respect of surrounding a person see Read $v$ Coker (1853, see n 547).

${ }^{943}$ Comyns refers to Rolle, $\mathrm{n} 21$, vol 2, 545, (referring to a case in 1353, see n 167). Cf. Comyns 'it is no assault if a man speak menacing or provoking words against another in his absence.' The wording has been placed in italics since it is asserted that, today, mere threats do not comprise an assault, unless accompanied with a gesture or act.

${ }^{944}$ Comyns refers to Rolle, n 21, vol 2, p 545 (referring to cases in 1458 and 1459, see n 551). Comyns also states 'for a threat seems to amount to an assault.' Pulton (see 12(a)) talks of 'forcible abusing'. The wording has been placed in italics since it is asserted that, today, mere threats do not comprise an assault, unless accompanied with a gesture or act

${ }^{945}$ Hawkins refers to Genner $v$ Sparks (see 14). See also Underwood v Hewson (see 18).

${ }^{946}$ Hawkins refers to Genner $v$ Sparks (see 14).

${ }^{947}$ See also Boulter $v$ Clerk (see 18) (fighting with fists).
} 
- $\quad$ Thrusts (or pushes) another in anger (also cited by Hawkins). ${ }^{949}$

- Spits in a person's face (also cited by Hawkins, Buller \& East). ${ }^{950}$

- Strikes a person's horse, throwing him. ${ }^{951}$

- In a struggle for the way (or other contest) a person touches another. ${ }^{952}$

- Disturbs a person building a booth. ${ }^{953}$

- Throws stones (molliter, i.e. softly) against a trespasser. ${ }^{954}$

- Bites off a person's finger. ${ }^{955}$

- Pushes a drunken man. ${ }^{956}$

- Takes a hat from a person's head in church. ${ }^{957}$

- Upsets a chair, to tip a person over. ${ }^{958}$

- Tosses a firework at someone. ${ }^{959}$

- Cuts another's hair, without consent. ${ }^{960}$

- Gives hair a tone rinse (when a permanent wave requested) causing a painful rash over the body ${ }^{961}$

- Pulls a person off a horse. ${ }^{962}$

- Pulls a shoe off a person's foot. ${ }^{963}$

- Throws stones, water or other liquid on a person. ${ }^{964}$

- Holds a person by his arm. ${ }^{965}$

- Delivers a sub-poena to a person. ${ }^{966}$

- Incites a dog to attack a person. ${ }^{967}$

- Kisses (or caresses) a person if they object. ${ }^{968}$

${ }^{948}$ Comyns makes no reference.

${ }^{949}$ Comyns refers to Cole v Turner ( see 14).

${ }^{950}$ Comyns refers to Cotesworth (see 14). See also Wife of Cloborn (see 14). See also Trindade, n 319, p 226 who also mentions cases of: (a) pulling away a chair so that a person falls to the ground; (b) forcibly taking a blood test; (c) firing a gun so close to a person's face so as to burn him; (d) snatching a book from a person; (e) grabbing a plate from a person's hand. See also Lynsey (1995), n 453.

${ }^{951}$ Comyns refers to Dodwell v Burford (see 14) and Anon (see 14). For other 'horse' cases see Gibbons v Pepper (see 14) and Lee $v$ Atkinson (see 14).

${ }^{952}$ Comyns refers to Cole v Turner (see 14).

${ }^{953}$ Comyns refers to Rolle, vol 2, 548 (referring to a case in 1433, see n 182).

${ }^{954}$ Comyns refers to Rolle, vol 2, p 548.

${ }^{955}$ See Cockcroft $v$ Smith (see 14).

${ }^{956}$ Buller cites Short $v$ Lovejoy (see 18)

${ }^{957}$ Comyns refers to Haw v Planner (see 14).

${ }^{958}$ See Hopper $v$ Reeve, see n 529.

${ }^{959}$ See Scott v Shepherd, see 18.

${ }^{960}$ See Forde v Skinner (1830) 4 C \& P 239 (172 ER 687)(battery on the part of parish officers to cut off a pauper's hair without consent). The law on unauthorized cutting off of hair and beards, to spoil a person's appearance, is very old, and the compensation payable was high. See Attenborough, n 6, p 79 (Laws of King Alfred 'If anyone ...cuts [the hair of an unoffending commoner] to insult him, in such a way as to spoil his appearance, he shall pay ten shillings compensation...if he cuts off his beard, he shall pay 20 shillings compensation.' See also $D P P$ v Smith [2006] 2 AE 16 (cutting of a woman's ponytail. Unfortunately Forde v Skinner was not cited in this case. In Anglo-Saxon times, the length and style of a person's hair appeared to denote their status. Attenborough, n 6, p 178 'The usual interpretation is that the long hair denotes the freeborn woman as opposed to the slave.' In early Germanic law, it also had the importance of determining a boy or girl's age. They had long hair pior to the age of majority (or legal age, being 12)) for the purpose of denoting their legal responsibility. At 12 a boy's hair was cut, a girl's was fastened up. See Drew, n 1, pp 38, 234 (also references in the Salic laws for punishments for cutting hair. See e.g. pp 144, 147, 197). See also KF Drew, The Lombard Laws (University of Pennsylvania Press, 1973), p 252 'The Germanic people looked upon the hair as being a mark of free or noble birth'. Thus, shaving of the head (a punishment) was a mark of supreme disgrace.

${ }^{961}$ Nash v Sheen (March, 13, 1953). Queen's Bench. See Weir, (Casebook), n 314, p 350.

${ }^{962}$ Lee $v$ Atkinson (see 14). See also Drew, $\mathrm{n} 960$ (in Germanic law, marahworfin (throwing a person from their horse) was a personal affront insulting and an offence, as was wegworin (blocking a person's way in the road).

${ }^{963}$ Cf. $R$ v George [1956] Crim LR 52 (D on two separate occasions attempted to forcibly remove a girl's shoe from her foot for personal gratification. Streatfield J held that no indecent assault). See also Trindade, n 319, pp 215-6.

${ }_{964}$ Comyns, $\mathrm{n} 26$, vol 2, p 30 refers to the Register of Writs, 108b, see Theloall, $\mathrm{n} 220,108 \mathrm{~b}$ the elongated version of which is cited in JB Ames, A Selection of Cases on the Laws of Torts (Cambridge, 1910), p 39 'Ostensurus quare vi et armis quondam liquorem callidum super ipsum I apud $\mathrm{N}$ projecit, ita quod de vita eius desperabatur et alia enormia etc., ad grave damnum etc. Casus erat huiusmodi praecedentis brevis: quaedam mulier projecit super aliam mulierem [h]ydro mellum quod Anglice dicitur Wort [i.e. hot mead] quod erat nimis callidum.' Comyns calls this an assault. However, it is asserted it is a battery. See also Simpson v Morris (1813) 4 Taunt 821 (128 ER 555)(trespass for throwing water over the P's apartment and herself), Pursell v Horne (see n 912) and Freeman v Home Office (No 2) [1983] 3 AE 589 (injected with mood changing drugs). See also Russell, n 588 (text).

${ }_{965}$ Comyns calls this an assault. However, it is a battery. Comyns refers to Rolle, $\mathrm{n} 21$, vol 2, 545 (referring to a case in 1402, see $\mathrm{n} 181$ ). Comyns also states that it is no assault 'to restrain him from a mischief to himself: as to hold one by his arm, who would stop his water, through down his booth etc.' He refers to Rolle, n 21, vol 2, p 547 (who refers to cases in $1402 \& 1433$, see ns 181 \& 182).

${ }^{966}$ Comyns calls this an assault and refers to Rolle, n 21, vol 2, p 545 (referring to Elpin v Hutton (1615)). However, it is asserted that, if there is any touching of a person, it is a battery.

${ }_{967}$ Comyns refers to Rolle, $\mathrm{n} 21$, vol 2, p 546 (referring to Walter $v$ Jones, see $\mathrm{n} 372$ ). The law on persons paying a fine if their dog bites someone is very old, see Attenborough, n 6, p 75 (laws of king Alfred, if a dog tears or bites a man, 6 shillings shall be paid for the first offence, 12 for the second and 30 for the third).

${ }^{968}$ In $R$ v Chief Constable of Devon and Cornwall [1982] QB 458, 471 Denning MR suggested that non-consensual kissing would be a battery (quoting Salmond on Torts, $17^{\text {th }}$ ed (1977), p 120). Also, 'the lifting up of a recumbent obstructor would be a battery unless justified as being done in the exercise of self-help'. See also KD v CC of Hampshire [2005] EWHC 2550. Cf. Street, n 163, p 6 who mentions an old 
- Gives a forcible injection. ${ }^{969}$

Chitty, $\mathrm{n} 261$, contains a useful list of precedents of indictments for assault in 1826 . They comprise indictments for:

- common assault;

- $\quad$ throwing on the floor and kicking;

- beating out an eye;

- tearing out hair;

- $\quad$ encouraging a dog to bite;

- $\quad$ assault with a walking stick;

- $\quad$ riding over a person with a horse;

- driving a coach against another;

- driving a cart against a chaise, and throwing the rider from it;

- $\quad$ assaulting the driver of a chaise;

- driving a cart against a chariot;

- $\quad$ presenting a loaded gun and threatening to fire;

- $\quad$ wounding with a bayonet;

- violent bruising with a fist;

- $\quad$ casting into a pond with intent to suffocate;

- beating and ill-treating an apprentice;

- $\quad$ whipping an apprentice and keeping her without food;

- compelling an apprentice to go naked into a frozen river;

- $\quad$ holding an apprentice near to a scorching fire;

- not providing sufficient food to a servant of tender age;

- $\quad$ assaulting a pregnant woman;

- $\quad$ assaulting a turnpike collector in the execution of his office;

- $\quad$ assaulting a constable in the execution of his office;

- $\quad$ assaulting a game keeper in the execution of his office;

- $\quad$ assaulting a person on a highway and defacing their garments (see Act of 1719, see n 694).

An earlier, and shorter, list of precedents of indictment for assault may be found in W Stubbs \& G Talmash, The Crown Circuit Companion ( $2^{\text {nd }}$ ed, 1749).

\section{APPENDIX F - LAW OF THE FRISIANS}

Han Nijdam, in a chapter in a text on Medicine and Law in the Middle Ages ${ }^{970}$ notes that the first compensation tariffs can be found in the Code of Hammurabi, dating to the $18^{\text {th }}$ century BCE. The purpose of this - and latter tariffs - was to substitute compensation as an alternative to revenge and the blood feud, based on a system of lex talionis.

- Nijdam notes that the laws of the Germanic people (Leges Barbarorum, $5^{\text {th }}-9^{\text {th }}$ century), which were re-dacted during the reigns of the Merovingian and Carolingian kings, established a commodity value of a human being (wergild) for compensation purposes. One which was not equal, being dependent on status.

- In particular, Nijdam refers to the Law of the Frisians (Lex Frisionum). It was drawn up towards the end of the $8^{\text {th }}$ century and it distinguished between noblemen (nobiles), freemen (liberi), half-free men (lites) and slaves (servi). Thus, the wergild of a freeman was twice that of a litus. The Frisians occupied the coastal part of what is now the south and north part of Holland and some of Germany. Nijdam considered the system of Frisian tariffs in the period 1100-1300. Like the Anglo-Saxon laws referred to in 3, Frisian law contained a detailed list of parts of the body as well as the compensation payable. There was a close commonality between the two.

- In respect of physical injuries to the human body, the Frisian tariff listed many features. These help explain why the Anglo-Saxon tariff also included certain features. Thus, Nijdam referred to: (a) pulling, singeing or cutting someone's hair; ${ }^{971}$ (b) throwing someone into water; (c) fettering someone or taking them hostage (i.e. false imprisonment); (d) robbing; (e) threatening; (f) chasing someone; (g) hitting

US case Goodrum v State (1878) 60 Ga 509 (caressing a woman is a battery if she objects - providing the offender does not occupy such relation as makes the act excusable). See also Trindade, n 319, p 225.

${ }^{969}$ Townley $v$ Rushworth [1964] Crim LR 591. See also Freeman v Home Office (n 964).

${ }^{970}$ WJ Turner \& SA Butler, Medicine and the Law in the Middle Ages (Brill, 2014), chapter 1, H Nijdam, Compensating Body and Honor: The Old Frisian Compensation Tariffs.

${ }^{971}$ See $\mathrm{n} 960$, re the English position as to cutting hair. 
someone in a humiliating way; (h) hitting someone so that he fell to the ground; (i) hitting someone unconscious; (j) pouring liquid over someone or spitting, urinating, throwing mud or dirt on them; ${ }^{972}(\mathrm{k})$ tearing up someone's clothes, tearing away their headdress, making someone look naked; ${ }^{973}$ (l) verbal injury (i.e. insult, defamation); (m) assaulting, or raping, a woman;

- Nijman also lists the various body parts described in the Frisian tariff. He notes the absence of reference to wounds to internal organs on the basis that this probably reflected what doctors were able to heal then (if a person died, the entire wergild was claimed). Hair pulling and insults were likely included in the tariff because they often led to a quarrel. Nijman also notes that bruises had to be visible to secure compensation. Wounds were determined by the inch (the measure for Frisian purposes being the first joint of the thumb), with higher compensation per inch. ${ }^{974}$ A distinction was made between bleeding, and non-bleeding, wounds;

- Nijdam also notes, with regard to the Frisian tariff, the presence of a 'law speaker' (asega) - one who knew the law by heart and who assisted the judge by providing information on the law and legal procedure involved. With high illiteracy rates in medieval times (and before) this may explain why the tariff tables changed so little (in England too), since they were learned by heart. Nijdam also notes the presence of a wound assessor (skrivere) who appears to have been an expert on injury compensation (he seems to have been entitled to part of any compensation for wounds awarded by the court);

- Thus, Nijdam notes that the body formed a core of 'embodied honour' for legal purposes; insult to the person, or to his body, affected his honour and communal esteem. Thus, visible scars or damage to the hair (a 'free' Frisian was defined by his hairstyle) required the payment of higher compensation. So too when the person was a noble as opposed to one of lesser rank.

Nidjam's explanation of the Frisian legal tariff helps explain the Anglo-Saxon tariff system which prevail from $6^{\text {th }}$ c - c. 1189. Why, for example, pouring liquid over someone (or damaging their clothes or hair) was treated as an insult to the body itself. The inclusion of threats and insults (affronts) in both systems (one would suggest) derives from the Roman law which held 'assultus' (i.e. to attack a person) could be either in a physical or a verbal form - likely because both produced a predictable result: a violent reaction. It may be noted that, apart from Frisian Law, other Codes, pre-1000, also possessed a tariff system. ${ }^{975}$

- Thus, the Visigothic Code (the laws of the Visigoths), promulgated by the Visigothic king of Hispania (Spain) c. 642-3, had a tariff; one which distinguished between freeborn persons and slaves. ${ }^{976}$ It was based on the principle of retaliation ${ }^{977}$ - save where the victim elected to receive financial compensation instead. ${ }^{978}$ Like the Anglo-Saxon system, this Code stipulated compensation which was payable for damage to the eyes, nose, loins, hands, fingers, feet, teeth etc. ${ }^{979}$ The Code also stipulated that it was not a crime to resist another by way of self-defence - including where the same was preemptory. $^{980}$

\footnotetext{
${ }^{972}$ See $\mathrm{n} 964$, re the English position as to liquids.

973 See $n 694$ and Act of 1719.

${ }^{974}$ At p 43 'For instance, in a shooting, the tariffs stipulated the measurement of the shortest distance across the body from the entrance of the arrow to the exit wound.'

${ }^{975}$ As KF Drew, The Lombard Laws (University of Pennsylvania Press, 1973) notedthat, when Germanic kingdoms started to take effect in the old Roman empire, p 13, 'most of the new Germanic kingdoms needed new codes of Germanic law, codes available in written form, for the instruction of the judges [prior to that the customary law was mainly oral]. Thus, a number of 'barbarian codes' were issued, such as those for the Visigoths, Burgundians, Ripuarian and Salian Franks, Ostrogoths, Lombards, and Anglo-Saxons.'

${ }^{976}$ SP Scott, The Visigothic Code (Boston Book Co, 1910), p 209 (concerning injuries, wounds and mutilations inflicted upon men) provided 'Where one freeborn person strikes another any kind of a blow upon the head, he shall pay five solidi for a bruise, ten solidi if the skin be broken, twenty solidi for a wound extending to the bone, and a hundred solidi where a bone is broken.' See also KF Drew, The Burgundian Code (from c. 516-27, University of Pennsylvania Press, 1972). It contains similar provisions on wounding, cutting hair etc.

${ }^{977}$ Ibid, p 211 'if any freeborn person should dare to shave the head of another; or should mark, or scar him by violence either upon his face, or upon any other part of his body, by the use of a scourge, a whip, or any weapon; or, by maliciously dragging him upon the ground, should soil or defile him; or should maim him in any part of his limbs...the same person shall receive by way of retaliation, whatever he inflicted, or attempted to inflict, upon another.'

${ }^{978} \mathrm{Ibid}$ 'And if he who suffered from his violence, or endured insult through his agency, should desire to receive pecuniary compensation from the culprit, he shall be entitled to recover such a sum as he may estimate will compensate him for the injuries he has sustained.'

${ }^{979}$ Ibid, p 212.

${ }^{980} \mathrm{Ibid}$, p 215 'It is no crime to resist another, where the violence of the attacking party is manifest. Whoever, therefore, should recklessly attempt to strike, or should strike, another with a whip, or sword, or with any weapon whatsoever, and the offender should then be so wounded by the party whom he attacks, that he dies, such death shall not be considered homicide, nor shall he be liable to any reproach who struck the fatal blow; because it is more proper for a living person to defend himself against an angry man, than to be revenged after his own
} 
- In conclusion, the Anglo-Saxon tariff system complimented that of similar systems on the Continent. The source for this was the Salic law of the Germanic people and its spread same across Europe on the fall of Rome. It also reached northern nations. ${ }^{981}$ The Germanic system was originally tribal and oral. However, as the German people began to settle within (and overcome) the declining Roman empire, their law was redacted into written codes; codes which reflected (sometimes) aspects of Roman law, as well as replaced aspects of own customary law when it was no longer adequate;

- As Drew noted, two concepts were important in the Germanic system and its royal control: (a) the Germanic concept that every man's person (and property) constituted a special domain protected by a peace - the violation of which (scandalum) was an offence; (b) the concept that the kingdom was the personal domain of the king protected by his peace - the violation of which was an offence against royal power. To 'breach the [royal] peace' was an offence, ${ }^{982}$ which offence included any violent act. ${ }^{983}$ In order to settle that peace once more, and to replace blood feuds (lex talionis), a detailed tariff stipulated the sum (the 'composition' or 'settlement') payable to the injured person or his family. Thus, the Germanic criminal legal system was based on the State (king) arbitrating 'peace' and taking a fine (wite) in payment for acting as mediator. ${ }^{984}$

- These Germanic law concepts Drew mentioned were also at the heart of the Anglo-Saxon legal system and they continued, along with the tariff, into Anglo-Norman times.

\section{APPENDIX G - TOURNAMENTS \& JOUSTS}

A useful text is that of Barber (see $n$ 151) from which the statements below are taken.

- $\quad$ Terms. In a 'tournament', two teams met, as if on a battlefield, in a general free for all (or melee). This was the most hazardous form of sport and it became increasingly rare (after 1342 it does not seem to have occurred in England). ${ }^{985}$ Later, the word 'tournament' was used to refer to any form of knightly (i.e. martial or military) combat. The alternative (common to England in the period 1100-1400) was a 'hastilude' (hastiludium). This was a game fought with spears and it came to be applied to all forms of mounted combat - whether en masse or individual. 'Jousts' were single combats - one against one - although the jouster could belong to a team. Up to 1400 , jousts were usually fought without a central barrier being used to separate the combatants. Lists were the enclosed area in which the tournament (or joust) was fought. From the $13^{\text {th }}$ century this tended to be a fenced enclosure. ${ }^{986}$ In the $14^{\text {th }}$ and $15^{\text {th }}$ centuries individual combats a outrance (i.e. under war conditions) were popular. ${ }^{987}$ After 1550, with warfare moving away from armour and shields, the tournament declined; 988

- $\quad$ History. Tournaments seem to have emerged as a distinct form of military (martial) game at the end of the $11^{\text {th }}$ century, probably in northern France. Several companies of knights took part (under the leadership of lords they served in war) and as many as 200 knights participated - the battle being fought over several miles of countryside. Tournaments in the $12^{\text {th }}$ century were little more than private free for alls. However, by the $16^{\text {th }}$ century, pageantry had mainly replaced the jousting. In the $14^{\text {th }}$ century, the contest of 'passage of arms' developed. This was where knights undertook to defend a given place (usually a ford or bridge) in single combat until they were defeated;

\footnotetext{
death. And whoever, in anger, draws a sword against anyone, even though he should not strike him, shall be forced, on account of his insolence, to give ten solidi to him whom he thus threatened.' For similar provisions in the case of the customary law of Catalonia in the $12^{\text {th }}$ century (which, effectively, updated Roman and Visigothic law with local custom), see DJ Kagay, The Usatges of Barcelona. The Fundamental Law of Catalonia (University of Pennsylvania Press,1994). See, in particular, pp 67-8 (striking another, hair pulling, assaulting and shedding (or not shedding) blood, shoving, spitting in the face).

${ }^{981}$ For the wergild system in Norway see L Larson, The Earliest Norwegian Laws (Columbia UP, 1935). See also A Dennis \& P Foote, Laws of Early Iceland: Gragas I (University of Manitoba Icelandic Studies). Ibid, Gragas 2.

${ }^{982}$ Drew, n 975, p 25. 'To breach this royal peace was to commit an offense that the Lombards termed scandalum'. (Drew was considering the laws of the Lombards (643-755) who established themselves in Italy after the collapse of the Roman empire).

${ }_{983}$ Ibid, 'any violent act was a form of scandalum and was thus an offense against the public peace as well as an offense against the injured individual or family. The royal courts therefore considered two offenses when they judged any violent act or any act that might lead to violence in retaliation, and accordingly the penalty, the compensation, was divided between the two offended parties: the royal court (the fisc) and the private party.'

${ }^{984}$ See also Drew, n 1, pp 35-6 (composition to the injured party and a fine to the court).

${ }_{985}$ Barber, n 151, p 34. See also OED, n 245 (tournament) 'A martial sport or exercise of the middle ages, in which a number of combatants, mounted and in armour, and divided into two parties, fought with blunted weapons and under certain restrictions, for the prize of valour'. Also (hastilude) 'Spear play: a name for a kind of tilt or tournament.'

${ }_{986}$ Barber, pp 2-4.

${ }^{987}$ Ibid, p 125

${ }^{988}$ Ibid, p 135. T Blount, A Law Dictionary ( $3^{\text {rd }}$ ed, 1717)(turney or tournament) 'the thing [ie the tournament] it self is now disused.'
} 
- Danger. Tournaments were a very dangerous sport - not least because there was always room for treachery and killing in anger. At first, there were few rules and no supervision. The object, however, was not to kill the opponent knight but to capture, and ransom, him. Death, or serious injury, seems to have been fairly frequent;

- Breaches of the Peace. Much of the documentation of the tournament was concerned with banning or controlling the sport, in order to avoid breaches of the peace. Townspeople often took part as foot soldiers to the knights. Further, since the tournament was also a pageant and there was a fair-like atmosphere - with the result that, often, it was seen as a place where theft, violence, drunkenness and lust could reign. ${ }^{989}$ Tournaments were also sometimes used as a cover for rebellion, such as in the reign of Henry III (1216-72) in England; ${ }^{990}$

- Ecclesiastical Censure. The ninth canon of the Council of Clermont in 1130 stated: 'we firmly prohibit these detestable markets or fairs at which knights are accustomed to meet to show off their strength and their boldness and at which the deaths of men and dangers to the soul often occur. ${ }^{991}$ This papal ban on tournaments was not removed until 1316. In particular, the purpose of the ban was likely aimed at the sin of homicide, as well as the profligate spending incurred by knights which often reduced them (and their tenants) to poverty. ${ }^{992}$ As an alternative, popes besought knights to go on crusade to the Holy Land. ${ }^{993}$

- $\quad$ England. Tournaments were prohibited in the reigns of Henry I (1100-35) and Henry II (1154-89). However, they occurred (with violent results) in the reigns of weak kings such as those of Stephen (1135-54), John (1199-1216) and Henry III (1216-72). ${ }^{994}$ They were especially popular in the reigns of Edward I (1272-1307) (a public edict in 1267 allowed them to be held throughout the realm) ${ }^{995}$ and Edward III (1327-77). A royal licence was usually required for them. In particular, Richard I (1189-99), by a charter of 22 August 1194, recognised 5 places in England as official tournament sites 'so that our peace shall not be broken, the power of our justiciar shall not be threatened and loss shall not fall on our royal forests.' ${ }^{996}$ To participate, a knight had to obtain a licence (in the form of a charter) to hold the tournament (it cost 10 marks). A person also had to obtain a personal licence to participate, in the form of a fee according to their rank (20 marks for an earl, 2 marks for a landless knight). Foreign knights were excluded. Richard's decree breached the church ban of 1130. Likely, it was designed to be a useful means of raising revenue as well as military training. In respect of the re-introduction of tournaments by Richard I, the $12^{\text {th }}$ historian William of Newburgh or Newbury (c 1136-98), in his History of English Affairs (Historia Rerum Anglicarum, written up to the year 1197), ${ }^{997}$ recounts:

'In the course of the truce between these kings [of France and England], those military practices, that is to say, exercises in arms, which are commonly called tournaments, began to be celebrated in England; and the king, who established them, demanded a small sum of money to be paid by each person who wished to join in the sport. This royal exaction had no influence upon the willingness of the young knights, who were fired with the love of arms, nor did it check their ardour, not prevent them from holding a solemn assembly for exercise; but it is notorious that a military conflict of this kind is never held in England, for exercise alone, and the display of valour, without some quarrel arising; unless in the days of king Stephen, when, through his unbecoming weakness, there could be no vigour in the administration of public discipline. Moreover, in the times of the kings before him, and also in the time of Henry the second, who succeeded Stephen, these knightly exercises were altogether forbidden in England; and those who, perchance, sought glory in arms, and wished to join these sports, crossed over the sea, and practiced them to the very ends of the earth.

\footnotetext{
${ }^{989}$ Ibid, p 16. See also p 146.

${ }^{990}$ Ibid, p 148. The English Act Statuta Armorum 1292 sought to regulate the numbers of retainers, armour and weapons. All officials were to wear proper identification.

${ }^{991}$ Ibid, p 17.

${ }_{992}$ Ibid, p 139. See also p 143 (knights imposed heavy dues on tenants to re-coup their losses).

${ }^{993}$ Ibid, p 140. Cf. Mirror of Justices (c.1290), n 23, pp 31-2 'As to adventures in tournaments, combats, jousts, and medleys, king Henry the Second [1154-89] ordained that, forasmuch as such sports are dangerous, everyone ought to prepare himself so that God may find him in holy life, that no one may be in mortal sin or hatred of another, but gave leave to every man to try his strength on others in good fellowship in public places in the aforesaid sports, whereby he might know how the better to defend himself against his enemies.'

${ }_{994}$ Ibid, p 19

${ }^{995}$ Ibid, pp 30-1.

${ }^{996}$ Ibid, p 25 ('Ita quod pax terrae meae non infringatur, nec de forestis nostris damnum inferatur'). These locations were Salisbury and Wilton (Wiltshire), Warwick and Kenilworth (Warwickshire), Stamford and Warinford (probably Suffollk), Brackley and Mixbury (Northamptonshire) and Blyth and Tickhill (Nottinghamshire).

${ }^{997} \mathrm{~J}$ Stevenson, The History of William of Newburgh (Llanerach Publishers, 1996 rep of ed of 1856), p 625. See also R Howlett (ed), Chronicles of the Reigns of Stephen, Henry II and Richard I (Cambridge UP), vol 2, pp 422-3 and SR Meyrick, A Critical Injury into Antient Armour ( $2^{\text {nd }}$ ed, 1842), vol 1.
} 
The illustrious king Richard, therefore, considering that the French were more expert in battle, from being more trained and instructed, chose that the knights of his own kingdom should be exercised within his own territory, so that from warlike games they might previously learn the real art and practise of war, and that the French should not insult the English knights as unskillful and uninstructed. Be it known, however, that exercises in arms of this kind were prohibited by three general councils, under three venerable pontiffs of Rome... Although such a solemn assembly of knights is forbidden by authority, under a heavy censure, yet the fervor of those youths, who in their vanity seek glory in arms, and who rejoice in the favour of kings, who desire to have expert soldiers, has treated with contempt the provisions of this ecclesiastical decree, even to the present day [i.e. the year 1197]

\section{APPENDIX H - LEGISLATIVE OFFENCES VIOLENT ASSAULT etc.}

\section{Violent Assault 998}

1.1. It is a violent assault to:

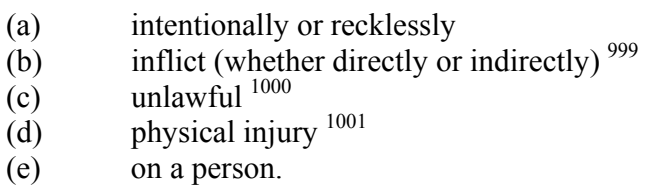

'Person' includes any clothes they are wearing, if the intent (or recklessness) was to inflict injury on the person and not only their clothes. ${ }^{102}$

1.2. The punishment for violent assault is [ ]. If it:

(a) is against a police constable acting in the execution of his duty (or a person assisting him) the punishment is [ ];003

(b) results in serious bodily harm, the punishment is [ ];

(c) is racially or religiously aggravated, the punishment is [ ]. ${ }^{1004}$

\section{Threatened Violent Assault}

2.1. It is threatened violent assault to:
(a) threaten a person
(b) so that he reasonably believes
(c) he will become subject to
(d) an immediate
(e) violent assault. ${ }^{1005}$

No crime is committed if the threat:

(a) is by words alone, without any accompanying act or gesture; or

(b) it is unobserved by the person; or

(c) it cannot be carried out and the person knows it.

\footnotetext{
${ }^{998}$ The word 'violent' per se excludes de minimis (minimal) battery.

999 'Inflict' is the English translation of Ulpian (percutere), see text to $\mathrm{n} 262$. Also referred to by Cowell, see 11(b).

${ }^{1000}$ For defences, see 38 \& 39. Legislation may also make certain matters lawful, such as tattooing.

${ }^{1001}$ The Law Commission proposed the word 'injury' in 1992 (see n 635, p 29. Also, p 31) and this word would seem apposite - as well as accurately reflect the position since Anglo-Saxon times (the alternative would be to refer to 'physical force' which is similar to the definition of Goff LJ in Collins $v$ Wilcock (see 30) viz.'actual infliction of unlawful force on another'). 'Physical' excludes psychiatric and psychological injury. Also, force would not seem appropriate in all circumstances. For example, air is force. However, to stand aside from a person intentionally (or recklessly) so that the wind blows on them, would not be a battery.

${ }^{1002}$ See 35(a). See also Donovan (n 541) at p 509, per Swift J 'bodily harm' has its ordinary meaning and includes any hurt or injury calculated to interfere with the health or comfort of the prosecutor. Such hurt or injury need not be permanent, but must, no doubt, be more than merely transient and trifling.' Cited by Lord Templeman in Brown (see n 631), p 230.

${ }^{1003}$ See 42. It would not seem necessary that an increased punishment should apply to person assisting a police officer. Thus, this wording is placed in italics.

${ }_{1004}$ See 47 . For the meaning of racially and religiously aggravated, see s 28 of the 1998 Act.

${ }^{1005}$ See Appendix C where 'apprehends' is used. However, 'apprehends' is a synonym for 'believes' or 'understands' in this instance (see LC 1992, in Appendix C). It is not a reference to 'apprehend' in the sense of becoming conscious of something, See OED, $\mathrm{n} 245$ (definition to apprehend) includes: 'To become or conscious by the senses of (any external impression). Also, 'to understand (although to be so and so) to conceive, consider, view, take (it) as.' See also Trindade, n 319, p 233-4 (reasonable apprehension). Ireland (1998, see Appendix C) refers to 'imminent'. However, 'immediate' would seem a better formulation. See also Trindade, n 319, p 233 (imminent bodily contact).
} 
2.3. The punishment for threatened violent assault is [ ]. Where the crime is racially or religiously aggravated, the punishment is [ ]. ${ }^{1006}$

\section{No Crime Committed}

3.1. No crime is committed under sections 1 or 2 where:

(a) the [CJIA $2008 \mathrm{~s} 76$ ] applies; ${ }^{1007}$ or

(b) a person consents to medical treatment or it is required in his best interests and he is otherwise incapable of giving consent $;{ }^{1008}$ or

(c) an activity (including a sport) is conducted within the limits of what is acceptable as incidental to social intercourse or life in the community. ${ }^{1009}$ However, no sport may, by its rules authorise a crime under section 1 .

'Medical Treatment' includes surgery, but does not include any non-therapeutic mutilation, save where legislation provides otherwise. ${ }^{1010}$

'Sport' means any game or sporting activity, whether organised or not and includes horseplay.

\section{Correction of a Child}

4.1. A parent may administer moderate physical correction to a child for providing no:

(a) crime is committed under section 1;

(b) implement is used;

(c) blow to the head is inflicted;

(d) shaking is inflicted. ${ }^{1011}$

'Parent' includes a person in loco parentis, including a teacher.

\section{Copyrights}

Copyright for this article is retained by the author(s), with first publication rights granted to the journal.

This is an open-access article distributed under the terms and conditions of the Creative Commons Attribution license (http://creativecommons.org/licenses/by/3.0/).

\footnotetext{
${ }^{1006}$ See 47. It is asserted that a separate exception in the case of a police constable is not required.

1007 This offence should be modernised to directly incorporate: (a) self-defence; (b) defence of others; (c) defence of land and possessions; (d) acts conducted pursuant to due legal process (arrest, service of criminal and civil process etc). It is asserted there should be no distinction between criminal and civil process.

${ }^{1008}$ See Re T [1988] 2 WLR 189 (patient could not consent because of mental illness). F v West Berkshire Health Authority [1989] 2 AE 545 (doctor can operate or give other treatment without consent if patient incapable of consenting (because of some incapacity) provided that the treatment is in the best interests of the patient and it is necessary to save his life or ensure improvement (or prevent deterioration) in his health (physical or mental).

${ }^{1009}$ This borrows from the definition of the LC in 1992 (see 31). The key word is 'incidental'.

${ }^{1010}$ Legislation makes provision on tattooing, see $\mathrm{n} 805$. It also prescribes female genital mutilation.

${ }^{1011}$ Alternatively, it may be preferable to prescribe the only forms of physical correction now permitted (e.g. a smack on the hand or bottom, without leaving a bruise or wound)
} 